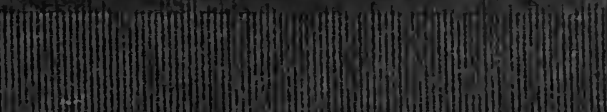




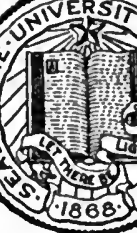

THE LIBRARY

OF

THE UNIVERSITY

OF CALIFORNIA

RIVERSIDE 
Rober f.. Kerner. 


\section{MUNICIPAL OWNERSHIP IN GREAT BRITAIN}




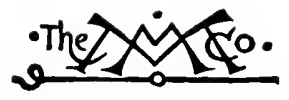




\title{
MUNICIPAL OWNERSHIP
}

\section{IN GREAT BRITAIN}

\author{
BY \\ HUGO RICHARD . MEYER \\ SOMETIME ASSISTANT PROFESSOR OF POLITICAL ECONOMY \\ IN THE UNIVERSITY OF CHICAGO \\ AUTHOR OF "GOVERNMENT REGULATION OF RAILWAY RATES"
}

\section{Nem 19ark \\ THE MACMILLAN COMPANY}

LONDON: MACMILLAN \& CO., LTD.

$$
\text { I } 906
$$

All rights reserved 


\section{HD D 4 4? 149}

Copyright, igo6,

BY THE MACMILLAN COMPANY.

Set up and electrotyped. Published April, tgo6.

J. S. Cusbing \& Co. - Berwick \& Smitb Co. Norwood, Mass., U.S.A. 
TO MY SISTER 
Digitized by the Internet Archive in 2007 with funding from

Microsoft Corporation 


\section{PREFACE}

THis book is the second of a series of four books which will give the results of the author's examination of the actual working, in important instances, of the public regulation and the government ownership and operation of the so-called public service industries: the railway, the telegraph, the street railway, the electric light, the electric power plant, and the telephone. The investigations in question have been carried on since the fall of 1892 , and they have covered the United States, Great Britain, Germany, and Australia. The books embodying the results of the investigations will follow each other in quick succession. But that does not mean that they are in any way hasty productions. It has been the author's policy to delay publication until he had covered the entire field, because he desired to put at the disposal of the public the means of comparing the experience of several countries in the various kinds of experiments, without long intervals between the successive books setting forth that experience. 



\section{CONTENTS}

\section{CHAPTER I}

INTRODUCTION

Special value of Great Britain's experiments. British inventiveness in check since 1870 .

\section{CHAPTER II}

The Tramways ACt, 1870 .

Attempts to build street railways in the sixties. The Act of 1870 leaves control with the municipalities. Street railway building paralyzed. Conditions which destroyed private initiative. Failure of attempts to limit veto power of municipalities. Burdens placed upon street railways. Standing Order No. 22 extends municipal veto to private charters. The bureaucrat versus the men of affairs. The cable system, like steam, not used on British tramways. Reasons for failure to develop electric tramways.

\section{CHAPTER III}

The Light RaIlways ACT, I 896 68

Administration of Act represses initiative in building tramways. Power of the municipal organizations. Science and industry no match for politics.

\section{CHAPTER IV}

The United Kingdom's Lack of StReEt RaIlways

Comparison of the street railway facilities of cities of various sizes in the United Kingdom and in the United States. 


\section{CHAPTER V}

\section{Glasgow}

City assumes operation of tramways in 1893 , using horse power. Glasgow opposes perpetual franchises - except for itself. Contrasts between promises and achievements.

\section{CHAPTER VI}

Glasgow proves that Graded Fares mean Congestion of Population

Statistical analysis of system of graded fares. Decentralization prevented by graded fares. Wage-earners get little benefit.

\section{CHAPTER VII}

EDINBURGH

The tramways, under private management, favor working classes. Development retarded by opposition of city. Company, discouraged, sells plant to city. Unbusinesslike management by municipality.

\section{CHAPTER VIII}

Birmingham .

Building of street railways discouraged. Lack of transit facilities and overcrowding.

\section{CHAPTER IX}

MaNChester, Leeds, Liverpool, Sheffield, aNd Bristol

\section{CHAPTER $\mathrm{X}$}

\section{GREATER LONDON}

Local and class interests check development of tramways. Parliamentary committee of 1872 . Recent opposition to tramways by private interests. Misuse of veto 
power by boroughs and county council. Inadequacy of

PAGB tramway service. Overcrowding perpetuated. Public necessity versus municipal gain.

\section{CHAPTER XI}

The Muncipal Purchases of Company Gas Plants 172

Sales of plants by companies usually compulsory. Municipalities profit from initiative of companies.

CHAPTER XII

The Electric Lighting Act, I882 . . . . . 184

Board of Trade misjudges situation. Opposition to long franchises. Development checked.

\section{CHAPTER XIII}

BACK to THE DaRK Ages . . . . . . 200

Attempts to liberalize the Electric Lighting Act. A study of the bureaucratic mind. Blighting effect of the Act of 1882 . Progress not worth its cost. Amendments abandoned.

\section{CHAPTER XIV}

The Cities confess their InCOMPETENCE to TAKe hold OF A New Industry . . . . . . . .

Report of Birmingham Committee of 1882 . The value of experiment and experience. Summary of the history of the acquirement of electric plants by Birmingham, Liverpool, Manchester, Sheffield, Leeds, Nottingham, Edinburgh, and Glasgow.

\section{CHAPTER XV}

The Municipalities VERSUS the Consumer

Act of I 888 aimed to remove prohibitive restrictions. Municipal policy prevents development. Administrative discrimination against companies. Municipal "orders" for "blocking" purposes. The United Kingdom outstripped by the United States. 


\section{CHAPTER XVI}

The Municipalities VERsus the Manufacturer

Wholesale supply of electricity prevented. Municipal opposition to progress. Needs of the manufacturers. The appeal to prejudice. Parliamentary grant rendered nugatory. Board of Trade sides with municipalities. Parliament helpless before the municipalities. Financial weakness of municipal undertakings.

\section{CHAPTER XVII}

The Municipalities VERsUS THE Wage-earners

British electrical industries outstripped. Loss of employment to wage-earners. Indirect harm to British wage-earners.

\section{CHAPTER XVIII}

The Municipal Employees

Politics and wages. Political power of employees. Costliness of municipal operations. House of Commons under civil service control.

\section{CHAPTER XIX}

Conclusion .

Governments rarely can reverse their steps. Progress dependent upon freedom in the United States. Governmental obstruction to progress. Industrial development due to individual initiative. 


\section{CHAPTER I}

\section{INTRODUCTION}

THE opinion is widely held, and is still on the increase, that the so-called municipal public service industries which make use of the public streets differ in vital respects from the ordinary trading and manufacturing industries. It is said that they should be made to share their profits with the public, as represented by the municipality, in return for the franchises which bestow upon them the right to make use of the streets, as well as confer upon them the monopoly of the right to supply. It is urged that the public should collect its alleged share of the profits of these public service companies, either by selling or leasing the franchises, instead of giving them without the exaction of a money payment, as has been the American practice in the past, or by subjecting the companies to special taxation, such as is not imposed upon other trading and manufacturing ventures.

It is also more or less widely held that the municipality should supersede the private company, by assuming the ownership and the conduct of the socalled public service industries. As has already been stated, the main argument advanced for these 
opinions is that the profits to be made in the industries that depend upon the right to use the streets belong in part to the public at large, as the owners of the streets. Of late, however, a second argument has been advanced - namely, that the public authorities, as the representatives of the people, are more solicitous of the comfort and welfare of the people than are trading companies, and that, therefore, they alone should be intrusted with the conduct of these public service industries which so vitally concern the people. This last argument is a wide departure from the spirit and belief of our forefathers, who were distrustful of the State and believed that, upon the whole and in the long run, the individual or company in pursuing its own selfish interest at the same time promoted the welfare of the community at large.

Great Britain has, since 1870 , applied the doctrine that the so-called public service industries differ from ordinary trading and manufacturing ventures to all Special Value of of the industries that make use of the Great Britain's streets except the gas-lighting indusExperiments

try. Therefore the experience of Great Britain has a double significance for us Americans. It is the experience of our cousins, who, like ourselves, have grown strong under "that liberty which is the nurse of all great wits" as well as of all spirit of adventure. It is furthermore the experience of a country that has treated one of the public service 
industries as if it differed not from any other trading venture, while it treated all the other public service industries as if they were things apart, to be subjected to special burdens and disabilities. In other words, the experience of Great Britain affords us the means of comparing the working over a period of thirty-five years of the two policies under discussion, and of ascertaining which policy has the better conserved and promoted the comfort and happiness of the individual, as well as the prosperity of the State.

Before proceeding to the consideration of the experience of Great Britain, it is well to remember that Great Britain's traders, manufacturers, and capitalists have a record for venturesome investment of capital, both at home and abroad, that extends over centuries and as yet has shown no signs of abatement; that in the engineering trades - to which the so-called public service industries belong Great Britain is second to no other country;* that in the past Great Britain has taken the leading position in the origination and introduction of the steam

* The Engineering Magazine, June, 1905.

\begin{tabular}{|c|c|c|}
\hline & $\begin{array}{l}\text { NUMBER OF PERSONS, PER } \\
\text { IO,000 OF POPULATION, } \\
\text { EMPLOYED IN THE ENGI- } \\
\text { NEERING TRADES }\end{array}$ & $\begin{array}{l}\text { ANNUAL VALUE OF ENGI- } \\
\text { NEERING EXPORTS, PER } \\
\text { WORKER, IN THE ENGI- } \\
\text { NEERING TRADES }\end{array}$ \\
\hline $\begin{array}{l}\text { United Kingdom, I90I } \\
\text { United States, } 1902 \text {. }\end{array}$ & $\begin{array}{l}301 \\
152\end{array}$ & $\begin{array}{r}\$ 223 \\
104\end{array}$ \\
\hline
\end{tabular}


engine, the steamship, the railway, gas lighting, and all the older branches of engineering, as well as of the earliest great electrical application, - that of the electric telegraph, both overland and submarine; that the earliest electric light, that of the arc, was discovered by Sir Humphry Davy, at the Royal Institution in Albemarle Street; and that in the same laboratories Faraday made those fundamental discoveries in electro-magnetism that rendered possible the dynamo, the electromotor, and the telephone. Again, the earliest electric accumulator was the gas battery of Sir William Grove. Varley and Wheatstone in London were the first to evolve the self-exciting dynamo machine. Swan made, and exhibited at Newcastle-on-Tyne, the earliest incandescent electric lamp; and, if the original telephone - that of Graham Bell - was an American invention, the transmitting instrument of to-day is in large measure based on the microphonic discoveries made in London by Professor Hughes.

"Nor in the earlier stages of practical electrical engineering was this country [Great Britain] in arrear of other nations. At a time when, in America and elsewhere, the design of electric generating machinery was in an entirely empirical condition, the late Dr. Hopkinson first worked out the correct underlying principles and put the design of dynamo machinery on a sure scientific basis. One of the earliest private electric-light installations in the 
world was that of Sir William Armstrong, at Cragside,* while one of the first electric railways $\dagger$ put down for practical use was that in Ireland between Portrush and the Giant's Causeway." $\ddagger$

The reader will note that the foregoing discoveries and achievements relate in the main to the period preceding the year I870. On the other hand, the British Inventive- electrical industries as we know them ness in Check since to-day have, in the main, been created 1870 since I870. Writing in I901, Mr. J. A. Fleming, F.R.S., an eminent British consulting electrical engineer, used these words in closing a review of the development of the electrical industries in the period from 1870 to 1900 :-

"In reviewing the nationality of those who have thus helped to make the electric current the nimble servant of mankind, it is impossible not to be struck with the fact that British names do not preponderate. In the region of pure scientific research, in the development of electrical theory, Great Britain has unquestionably held her own with the world. In detailed improvements or adaptations we have not been backward, but if we except the inventions of Lord Kelvin in connection with submarine teleg-

* The machinery was driven by water-power, and the current was carried a distance of one mile to Cragside, in 1882. The plant was designed by the German engineers, Siemens Bros. \& Co., of Berlin, London, and elsewhere.

+ In 1883 . The current was taken from a side-exposed conductor rail. The system was retained in use until 1898 , when the overhead system was installed.

$\ddagger$ A. A. C. Swinton: Electrical Engineering and the Munici,yaities. 
raphy, Mr. Swan in electric lighting, and the contribution which the late Professor D. E. Hughes made to telephony by the invention of the microphone, it is difficult to name any first-rate new adaptation of electrical discovery for practically useful purposes in the last thirty years which has not come to us first from non-British sources. It cannot be said that the country which has produced a Watt, a Stephenson, and an Arkwright is deficient in mechanical inventiveness, but it is impossible to deny that the period of time since 1870 has not been marked by the evolution of distinctly novel electrical inventive ideas proceeding from British minds."

The writer concludes with the words:-

"The matter is not one to be lightly dismissed; the development of national inventiveness is at least as important in the world-struggle of nations for existence as the preservation of national physique. We are apt to consider that invention is the result of the spontaneous action of some heaven-born genius whose advent we must patiently wait for, but cannot artificially produce. It is unquestionable, however, that education, legal enactments, and general social conditions have a stupendous influence on the development of the originative faculty present in a nation, and determine whether it shall be a fountain of new ideas or become simply a purchaser from others of ready-made inventions." *

\section{* The Nineteenth Century, February, Igor.}




\section{CHAPTER II}

THE TRAMWAYS ACT, I870

IN I858, the leading stockholders in the General Omnibus Co., of London, impressed with the success of the street railway in the United States, asked Parliament for a charter for street railways in London. The request was denied. Sir Benjamin Hall, Chief Commissioner of Works for Metropolitan London, moved the rejection of the Bill, saying: "They asked for power to appropriate 16 feet in width of the public thoroughfares of the metropolis, in order that their omnibuses might run on rails laid for that purpose. Now as some of the public thoroughfares were only i 8 feet wide, only one foot would be left on each side for the accommodation of carriages, carts, and all the ordinary traffic. It must be admitted that there was hardly a thoroughfare in the metropolis at present sufficiently large to accommodate the existing traffic, and he, therefore, thought it a monstrous proposition to ask permission to appropriate 16 feet of a highway to the purposes of a private omnibus company." *

* Hansard's Parliamentary Debates, March I5, I858, p. I 75. 
In 1860 , some British capitalists, under the leadership of an American, the late Mr. George Francis Train, built a street railway in Birkenhead, a suburb Attempts to build of Liverpool. They had no parliaStreet Railways mentary charter * but acted with the in the Sixties consent of the local authority - which, however, had no lawful right to grant power to break up the streets for the purpose either of constructing or of repairing street railways. The opposition of the owners of pleasure vehicles and of the proprietors of retail stores was persistent, and culminated, in 1865 , in an action at law, which asked that the tramways be condemned as a nuisance. But the local jury before whom the case was tried found that the tramways were a public benefit, not a nuisance. $\dagger$

On April ı6, I861, the House of Commons again rejected an application for a charter for Metropolitan London; and on April 26, it negatived, by a vote of 40 to 20 , a motion for a Select Committee " to inquire into the propriety of establishing a mode of public conveyance by means of iron rails in the streets and highways." $\ddagger$ Baffled in their parliamentary efforts, Mr. Train and his British supporters laid down several lines on the strength of mere agreements with several of the local authorities forming a part of

* Report from the Select Committee on Tramways Bill, 1878, q. 1252.

$\dagger$ Hansard's Parliamentary Debates, March 3, 1896, p. 546, Captain Grosvenor.

$\ddagger$ Ibid., April 16, 1861, p. 639; and April 26, p. I155; and The Municipal Journal, January 22, I904. 
Metropolitan London. From the Marble Arch along Bayswater Road, from Westminster to Victoria Station, and from Westminster Bridge to Kensington Park, tramway lines were opened; but the violence of the ensuing agitation led to their hasty removal.

In May, I862, Mr. Ayrton, a private member of Parliament, obtained leave to bring in a "Bill to authorize the construction of tramways on turnpike roads and other roads in England." But in July he abandoned the bill, saying: "He hoped, however, that the government would take up the Bill in the next session, for it was the Government alone that could combat the powerful private interests which demanded undue concessions." *

In 1863 , Mr. 'Train and his supporters, acting once more without authority from Parliament, laid down a tramway between Burslem and Hanley, as well as one at Darlington. In 1865 a further unsuccessful effort was made to obtain charters for street railways in London and Liverpool. In 1868 the House of Commons threw out the application of a company that desired to begin by building tramways in 26 miles of street in London, $\uparrow$ but at the same time it granted charters for Liverpool, and Glastonbury and Street. In 1869 Parliament sanctioned three

* Hansard's Parliamentary Debates, May I3, r862, p. I6r9 and following; June 3, p. 1619; and July 23, p. 7 о I.

† Ibid., March 5, 1868, p. I109 and following. 
street railway schemes for $4 \mathrm{I}$ miles of street in the suburbs of Metropolitan London; * and finally, in I870, it enacted a general act providing for the granting of charters for street railways.

In the meantime, the men who had met with rebuff after rebuff from Parliament, nothing daunted, had turned to the Continent; and, in the period of I 864 to I 87 I, they had built street railways in Copenhagen, Brussels, Paris, Bordeaux, Geneva, Madrid, Genoa, Vienna, Berlin, Barcelona, St. Petersburg, and Constantinople. $\dagger$ This record of persistent appeals to Parliament, of repeated building of street railways in Great Britain with no lawful public authority for such building, and of building street railways on the Continent, where the people were much poorer than in England and were therefore less likely to ride upon the tramways, should be sufficient answer to the misinformed or disingenuous persons who are in the habit of telling us that the municipal ownership of the street railways in Great Britain had its origin in the unwillingness of private enterprise to afford adequate transportation facilities.

In March, I870, Mr. Shaw-Lefevre, Parliamentary

* Hansard's Parliamentary Debates, March 3, 1869, p. 543 and following; and May I3, p. 735 and following.

+ Reports respecting Tramways in Foreign Countries, 1872; Further Reports respecting Tramways in Foreign Countries, 1872 . Report from the Select Committee on Tramways Bill, 1870, q. 947, I I4 I, and 1218 ; and Report from the Joint Select Committee on Municipal Trading, 1900, q. $145^{2}, 1457,351,356,373$, and 370 . 
Secretary to the Board of Trade, moved leave to bring in the Tramways Bill, I87o.* He said: "Honorable Members must be aware that there were before them numerous Private Bills asking powers to lay down tramways in the streets of our principal towns. In all, there were 27 companies asking for such powers over $5^{1} 5$ miles of road, with a capital of $\$ 20,000,000$. For London alone there were seven companies seeking these powers over I 25 miles in some of the most important streets; while others had in contemplation systems of tramways for Manchester, Liverpool, Birmingham, Leeds, Glasgow, Portsmouth, and Plymouth. Now, previous to this year, as far as he was aware, only six Private Acts had been passed authorizing tramways. Of these, three companies had obtained powers to lay down and work tramways in London south of the Thames, . . . and although an attempt had been made to show that the Committee (I869) authorized the making of these tramways, as an experiment, he was assured by his honorable Friend (Mr. Sclater-Booth, Chairman of the Select Committee of I869) that that was not the case, that the Bills were passed on their own merits, and under the full belief, founded upon the evidence, that they would be a success, and would be a great convenience to the public." He referred to the evidence before the Committee (of I869)

* Hansard's Parliamentary Debates, March r, 1870, p. Io80 and following. 
as to the working of tramways laid (by Englishmen) upon improved principles in many of the leading cities of Europe, particularly at Berlin, Vienna, Brussels, Copenhagen, Geneva, and said: "The evidence, indeed, seemed to him to establish that the more crowded a street was, and the greater the traffic of all kinds, the more useful and important was the tramway, subject only to this, that the street was wide enough to afford room for other carriages to pass on both sides of the tram. Subject to that, the tramway appeared to have the effect of regulating the traffic by sending it in straight lines, and by affording relief to all those vehicles which, although not fitted with flange wheels, could use the rails with their ordinary wheels. . . . He believed the opposition to these Bills would not be against the principle (of tramways); but on the part of local authorities to the effect that they did not wish to part with the control over their streets, and that they were prepared themselves to undertake the task of laying down and repairing the tramways in the streets, and of letting them on lease to private omnibus companies on charging tolls for the use of them. He had received deputations during the last few days from the municipal authorities of Manchester, Leeds, Birmingham, Salford, and Stockport, to that effect, praying that they might be allowed the opportunity of making tramways themselves."

The charters granted in 1868 and 1869 had con- 
tained clauses giving the local authorities power to purchase the street railways at the expiration of a specified period at the actual value, plus 30 per cent for good-will.* Of these clauses Mr. ShawLefevre said: "He might mention here that the clause for purchase under the Acts of $x 869$ appeared to him to be so drawn as really to make it impossible for any local authority to carry it out. They included in the purchase money to be given for the undertaking not only the value of the tramway, but also good-will, and prospective profits would be excluded; the local authorities would have the right to purchase after 2 I years, on payment of the actual value of the tramway and the other property of the company necessary for working the same. The only question which could arise upon this was whether capital could be raised upon such terms. He could not, for his part, doubt that it would, the more so, as he had inserted no limitation of dividend in the interval, and no compulsory lowering of fares. . . . Now, although the Bill would give power to local authorities to construct tramways, but not, of course, to work them - yet he believed that, as a general rule, they might look forward to the tramways being constructed rather by companies than by municipal authorities; but there was a process under this Bill, which he thought might with advantage be resorted

* Report from the Select Committee on Tramways Bill, I870, q. I I I to II33; and The Municipal Journal, March 3I, I905. 
to by municipal authorities who wished to have the general control over the laying down. It was that which would enable local authorities to apply to the Board of Trade for a certificate for tramways upon a general system within their district, and, having obtained the necessary powers, to sell or lease the concession to a company or companies. Under this provision a corporation* would have the power to lay down a general plan for tramways, and then to offer it as a whole or in sections to competition. The consent of the Board of Trade would be necessary for any such transaction, and the principle to be acted upon in such cases appeared to him not that very great profits should be made for the ratepayers, but that the public should gain as much as possible by lowering the fares. He did not think that profit should be made by local authorities out of tramways at the expense of the general public, for whose use they were intended, and more good was to be arrived at by reducing fares than by reducing the local rates (taxes). This was the principle which was not laid down in the Bill, but would be left to the Board of Trade, to carry out in its application of the Bill."

Before the Select Committee to which the Bill was referred, Mr. John Morris, of Ashurst, Morris \& Co., solicitors, appeared as the "selected witness of the tramway interests." Mr. Morris himself was a

* Throughout this book the word "corporation" is used in the British sense, - that is, to denote a city. 
stockholder in the tramways of Brussels, Genoa, and Copenhagen. $\mathrm{He}$ asked that the clause authorizing the municipalities to purchase at the end of 2 I years on the basis of "the value of the tramway estimated as a constructed work, such value to be in case of difference determined by an engineer or other fit person nominated as referee by the Board of Trade" be changed to "actual structural value, plus 30 per cent." He asked for the allowance of 30 per cent on the ground that 2I years would not always be a sufficient period to allow a company to make good the losses incurred in the early years; and that the price of the material used in building a tramway might decrease very much during the life of the charter, and thus make a sale on the basis of the mere value of the material in the tramway a hardship.* Parliament overruled this request of the men who for twelve years had been seeking permission to build street railways in Great Britain, and had carried the tramway to upward of a dozen cities on the Continent. The purchase clause enacted, read: "upon terms of paying the then value (exclusive of any allowance for past or future profits of the undertaking, or any compensation for compulsory sale, or other consideration whatsoever) of the tramways, and all lands, buildings, . . ." $\dagger$

When Parliament enacted the purchase clause put

* Report from the Select Committee on Tramways Bill, I870, q. I I I I to I 32 , and $x 198$.

† 33 and 34 Vict. c. 78 , s. 43 . 
forward by the municipal corporations, rather than the purchase clause put forward by the men who The Act of 1870 stood ready to build the tramways, leavescontrolwith it yielded to the contention of the the Municipalities municipal corporations, that the profits derivable from industries that use the streets should be applied to the reduction of the taxes, and should not be permitted to flow into the pockets of "speculators." That contention, or doctrine, was clearly enunciated in 1874 by Mr. Joseph Chamberlain, then Mayor of Birmingham, in the course of his speeches in support of his proposal that Birmingham purchase the gas plant belonging to a joint stock company. Before a Select Committee of the House of Commons, Mr. Chamberlain, as a witness, said: "It is with the object of diminishing the direct taxation of Birmingham that we are promoting this Bill" (to acquire the gas works). In the Birmingham Council, he said: "All these duties (street widenings and the rebuilding of unsanitary districts) involve a largely increased expenditure, and I believe that the pressure of the rates will become intolerable unless some compensation can be found by some proposal, such as this one I now lay before you. *... When the purchase of the Water Works comes before you, it will be a question concerning the health of the town; the acquisition of the Gas

* Report from the Joint Select Committee on Municipal Trading, 1900, E. O. Smith, Town Clerk of Birmingham, q. I894. 
Works concerns the profits of the town and its financial resources. ... Both are matters of absolute public necessity. . . . I distinctly hold that all monopolies which are sustained in any way by the State ought to be in the representatives of the people, by the representative authority should they be administered, and to them should their profits go, and not to private speculators. In the second place ... I am always inclined to magnify my office (the Mayoralty): I am inclined to increase the duties and responsibilities of the local authority, in whom I have myself so great a confidence, and will do anything in my power to constitute these local authorities real local Parliaments, supreme in their special jurisdiction."* To this same doctrine subscribed also the Joint Select Committee of the House of Lords and the House of Commons on Tramways, 1872 , in the following statement: "We are far from being insensible to the advantages attaching to the construction of tramways by an authority having entire control over the tramway and roadway, and able to devote the profits arising from the undertaking to the relief of the rates. We think it, however, premature to discuss in any detail the question of central management of Metropolitan Tramways by a municipal authority which has yet to be created, though we are of

* N. M. Morris: Joseph Chamberlain, The Man and the Statesman, PP. II 2 and III. 
opinion that when such an authority is established, every facility should be afforded to enable it to obtain possession of the tramways by purchase upon fair terms, at the earliest possible period." And finally, one may cite the argument made in I869, and repeated in $I 87 \mathrm{I}$, by the vestry of the Parish of St. George, Hanover Square, London, against the granting of street railway charters to stock companies. "The Metropolitan Board of Works has already undertaken two great works drainage and embankment of the Thames - which, important and valuable as they are, have resulted in heavy pecuniary burdens to the ratepayers of London. It seems then only fitting that the carrying out an operation such as the construction of Tramways (which promise large pecuniary returns) should also be placed in their hands for the benefit of the ratepayers." *

In 1870, Mr. Shaw-Lefevre had stated that 27 companies were asking Parliament for charters covering 5 I5 miles of street. In 1880 , there were Street Railway in the entire United Kingdom only Building para- 386 miles of first main track of street lyzed railway. In that same year, there were in the United States, in the cities of 50,000 and more inhabitants, no less than ${ }_{5} 84$ miles

* Keport of Proceedings of the Bocrd of Trade under the Tramueras Act, 1870, with regard to the Proposed Tramways in and about the Metropolis, May 3, 1871; and Hansard's Parliamentary Debates, March 3, 1869, p. 547 . 
of first main track of street railway.* In the United States there were living, in 1880 , in cities of 50,000 and more inhabitants, $8,700,000$ people. For England and Wales the corresponding figure was 10,300,000 people. Had England and Wales possessed the same mileage of street railway as the United States, in proportion to its population living in cities of 50,000 and more inhabitants, it would have had, in 1880 , no less than 1875 miles of first main track of street railways. This comparison takes no account of the 466 miles of first main track in the United States, in I880, in cities of less than 50,000 inhabitants.

In I890, the cities of the United States having 50,000 and more inhabitants had 3205 miles of first main track of street railway. Had the corresponding cities of England and Wales had a proportionate mileage, they would have had 3 I90 miles of first main track. As a matter of fact, England, Wales, Scotland, and Ireland had an aggregate mileage of 948 miles only. This comparison again takes no account of the 2578 miles of first main track in American cities of less than 50,000 inhabitants. If the latter mileage be taken into account, England and Wales, in 1890 , must have had fully 5200 miles of first main track of street railway, before the people of England and Wales could have been said to be

* Report on Transportation Business in the United States at the Eleventh Census, I890, Part I. 
as well supplied with street railway facilities as were the people of the United States.

In 1890 , street railway building for the time being came to an end in the United Kingdom. In the five years ending with 1895 , there were opened in the United Kingdom only 34 miles of street railway: horse, cable, and electric.*

While the municipalities, in 1870 , brought pressure to bear upon Parliament to secure the enactment of an act which practically paralyzed street railway building, so far as private enterprise was concerned, they did not themselves, in the years following 1870 , step in to fill the void created by the paralysis of private initiative. In 1878 , the $\mathrm{mu}$ nicipalities had built only 45 miles of tramway; by I 888 , they had built only 236 miles; and by I89I, they had built only 255 miles. After I892, the municipalities began to acquire tramways under the purchase clause of the Tramways Act of I870; and in 1897 , they began to build a little more freely. At present practically all street railway building under the Act of 1870 is carried on by the municipalities. Private companies build almost exclusively under authority obtained under the Light Railways Act, 1896 , which measure will be discussed on a subsequent page. . At the close of 1904, the local authorities owned I 48 miles of first main track of tramway; and the companies owned 692 miles.

* Current issues of the annual Return relating to Street and Road Tramways, etc., issued by the Board of Trade. 
In justice to the municipalities it should be added that down to 1896 Parliament refused to give the local authorities power to operate street railways, unless they should become, and should continue to be, unable to find tenants for their property.* That disability undoubtedly acted as a check upon municipal building; but it does not account for the complete failure of the municipalities to fill the void created by the paralysis of private initiative. The municipalities have invariably failed to contribute to the establishment of a new industry, or to the advancement of an established one. That has been true successively of water works, gas works, horse tramways, electric lighting, electric tramways, and the telephone.

For two reasons the Tramways Act, I870, paralyzed private initiative. In the first place, men soon Conditions which learned that it takes time to build up destroyed Private an extended street railway system; Initiative and that the losses suffered in the early years of the venture cannot always be made up in the lifetime of a charter limited to twenty-one years, with provision for sale on the basis of the value of the material put into the plant. That lesson was learned so thoroughly that to this day English capitalists look askance at street railway ventures. Many of the largest and most promising schemes now

* Report from the Joint Select Committee on Municipal Trading, I900, p. 354 , Sir Courtenay Boyle, Permanent Secretary to the Board of Trade. 
being carried on in England are supported by American capital.

The second reason for the disastrous working of the Tramways Act, 1870 , is to be found in the abuse of the power of veto conferred on the municipalities. The act authorizes the Board of Trade, with the consent of the local authority concerned, to grant companies provisional charters, so-called Provisional Orders. These Orders must be laid before Parliament, and if that body does not disallow them, they become Acts of Parliament. The consent of the local authority was required by the Act of 1870 because, in I870, many people deemed the street railway a nuisance; and because the local authority might choose itself to build the tramways. So far as the government of the day was concerned, there was no thought of enabling the local authorities to sell their assent that a Provisional Order be given to a company. Indeed, it will be remembered that Mr. Shaw-Lefevre expressly stated that it was impossible to make the tramways both contribute to the public treasury and provide cheap and extended service to the public. None the less, the local authorities rarely gave their assent to the Board of Trade granting a Provisional Order to a company; they almost invariably sold it.

As early as 1872 , Mr. Newton, late chairman of the Metropolitan Board of Works' Parliamentary Committee on Tramways, stated before the Joint 
Select Committee on Tramways (Metropolis) that: "Under the Act of Parliament the road authorities (vestries and parishes) and the local authority (Metropolitan Board of Works) have concurrent jurisdiction; and the Board of Trade was prohibited from granting Provisional Orders unless the promoters obtained the consent of two-thirds of the road authorities upon the line of a particular tramway. It was very difficult to get that majority. Some of the road authorities were willing, but some wanted to make better terms for themselves. They were exacting as to the quantity of paving which should be done by the Tramway Company,* and the local benefits which should be conferred, and in that way some refused their consent; some were willing for one company and some for another, just as they could get the greatest promises from them as to what should be done; the consequence was that, in some instances, the consent of two-thirds of the road authorities was not obtained. . . . I think it would be very much better if that sort of authority is exercised in the future, that there should be a power in the Board of Trade to decide upon the merits of a scheme after hearing both parties, without its being necessary that two-thirds of the road authorities should be in favor of any particular company." $\dagger$

* That is, in excess of the amount fixed by the Act of $1870,-$ namely, the space between the rails and to points 8 inches to the side of the rails. $\dagger$ Report from the Joint Select Committee on Tramways (Metropolis), 1872 , q. 463 . 
Mr. Hopkins, engineer in chief to tramway companies operating in London, Liverpool, Dublin, and Glasgow, said: "When we lay down a tramway in Metropolitan London in a road already paved, we have to pay the local authorities for the existing paving $\$ 2.25$ to $\$ 2.50$ a yard. The local authorities say, 'If you can afford to build a tramway in a macadamized road and pay for the cost of (granite) paving, you can afford to pay us the cost of the paving which is already there." Mr. Hopkins continued with the statement that at $\$ 3$ a yard, the company had to pay $\$ 30,000$ per mile of double track for existing paving. The practice "is becoming more general every day; we had not to do it in the earlier days." *

In the course of the proceedings of the Select Committee on Tramways, I877, Mr. Salt, the chairman, stated that in 1872 the towns of Aberdeen and Dundee $\uparrow$ had made it a condition of their assent to a Provisional Order that after the dividends of the respective tramway companies should reach a certain point, the towns should receive rentals of respectively $\$ 100$ a mile and $\$ 500$ a mile. He added, "In the case of Provisional Orders it is quite possible that clauses may be introduced which may not only override the principles of the public law, but may actually, in that particular case, repeal clauses of

* Report from the Joint Select Committee on Tramways (Metropolis), $1872, q .67,68,184,187$, and 1249 .

f Population in 1871: Aberdeen, 88,000; Dundee, $121, \infty 00$. 
the public law." To Mr. R. H. Wyatt, a parliamentary agent in the service of the government, the chairman said: "Any kind of bargain, good or bad, pure or corrupt, may be made (with a municipality) before a Provisional Order is put forward for consideration in a public office (the Board of Trade); is not that so?" Mr. Wyatt replied: "I think the present system is in that respect most objectionable; I can quite understand why the consent of the local authorities was to be obtained in the first instance when tramways were a mere experiment, but now that they have become an established fact, I think that power of vetoing the proceedings in Parliament (or before the Board of Trade) is most objectionable. Of course facts have come to my knowledge in confidence which I could not reveal here; but the system is abused. ... We know that it works very unjustly, and, in the interests of the public, it is very objectionable in this way: that if blackmail (I do not use the term offensively) is exacted in any shape, whether in the shape of a condition that they shall pave the streets, or that they shall pay any sum of money for widening bridges, or anything of that kind, if they cripple the bromoters, it is impossible that the undertaking can pay, and if it does not pay, the public is not well served." *

Before the Select Committee on Tramways, i 878 ,

* Report from the Select Committee on Tramways (Use of Mechanical Power), I877, q. 2645 to $26_{5}$ I. 
Mr. D. Parrish, who had built the first tramway under parliamentary charter, said: "I have had considerable experience in dealing with road authorities, and I have found them sometimes very difficult to deal with, and very difficult to make any terms with at all; they seem to look upon a tramway company as one who ought to pay most of their road expenses, and, in fact, they ask for very many extraordinary clauses. . . . Out of four Bills which I am promoting this Session, two have been withdrawn on account of our being unable to come to terms with the local authority." One of the Bills withdrawn by Mr. Parrish had asked for a charter in Bradford. The municipality had insisted on a clause giving it power to order at any time the removal of the tracks, without compensation, and without proof of nuisance. As far back as 1872 , Mr. Parrish had obtained from Bradford a charter with that clause in it, but he had been obliged to let the charter lapse, being unable to raise money under it. Mr. Parrish added that it was very desirable that, for causes of that kind, there be given power of appeal to the Board of Trade.*

Mr. Hopkins, engineer in chief to tramways in London, Liverpool, Dublin, and other important cities, said: "Speaking generally, local authorities never give their consent for the laying down of tram-

* Report from the Select Committee on Tramways (Use of Mechanical Power) Bills, 1878, q. 1244 to 1247 , and 1330 to 1340. 
ways; they sell it. . . . We find it very hard to get any fair terms from the road authorities. . . . To my knowledge, this very Session, a great many Tramway Bills have been withdrawn, simply on the ground of the excessive terms put upon them by the road authorities. . . . Where unreasonable terms are asked, I think that an appeal to the Board of Trade would have been an immense benefit, up to the present time for the tramway companies. . . . I know cases where the tramway companies maintain the whole road."*

Section 34 of the Tramways Act, 1870 , reads: "All carriages used on any tramway shall be moved by the power prescribed by the special Act, and where no such power is prescribed, by animal power only." Under that clause, in 1876 , a number of promoters of Bills applied for authority to use steam or other mechanical power. The proprietors of cabs and omnibuses, who feared trade competition; the owners of carriages, who asserted that crossing street railway tracks jolted them, and injured their carriages; and the proprietors of the more fashionable retail stores, who asserted that the passing cars interfered with the carriages of their customers, made these applications for power to use steam on the tramways

* Report from the Select Committee on Tramways (Use of Mechanical Power) Bills, 1878 , q. 879 to 886 , and 98 r to 984 .

It may be added, in passing, that whenever the distance between the outer rail and the curb is less than $9^{\prime} 6^{\prime \prime}$, the local authorities stipulate that the tramway company pave and maintain the entire street. In Metropolitan London the companies are obliged to pave and maintain the entire street whenever the width is less than 30 feet. 
the excuse and occasion for a renewal of the war of long standing that they had waged against the street railway. The Government was unwilling to assume the responsibility of offending those interests, and therefore it rejected all but two of the applications for permission to use steam or other mechanical power. Those two applications were unopposed: one was for a country tramway connecting Wantage with the Wantage railway station; the other was for the tramway between Glasgow and Govan, operated by the Vale of Clyde Steam Tramway Co. In these instances, the Government sanctioned the use of mechanical power, "but only as an experiment."

In 1877 there were applications from Birkenhead, Dublin, Edinburgh, Glasgow, Galway, Ipswich, Failure of At- Leeds, Leicester, London, Bristol, tempt to limit Dewsbury, Nottinghamshire, ShefVeto Pozver of field, Swansea, and Wolverhampton. Municipalities

Mr. Raikes, Chairman of Committees of the House of Commons, moved for a Committee "to consider, how far, and under what regulations, the employment of steam or other mechanical power may be allowed upon tramways and public roads." He said that, from a reading of clause 34 of the Act of 1870 , "it appeared that Parliament had in its mind at the time the possibility of other than animal power being employed, but no general principle was laid down (in I870) as to its desirability or undesirability." On a subsequent occasion, he said: "I 
assume that as far as we have hitherto gone in our legislation, we have not had expressly under consideration of this House the possible use of steam upon street tramways." The Select Committee was granted; and it reported in favor of the use, experimentally, of mechanical power. On May I I, I877, the Government brought in a Bill based on the report of the Select Committee, but the opposition of the municipalities was such that the Government withdrew the Bill on June 28 .*

In 1878 , the House of Commons again referred to a Select Committee the question of the use of mechanical power. Once more the report was in favor of permitting the use, experimentally, of mechanical power. The Chairman of the Committee, Mr. Arthur Peel, said in the House of Commons: "The evidence in favor of steam had been really so overwhelming, that they (the Committee) had assumed as a fact that steam ought to be permitted, although they fully recognized that it ought only to be permitted under the most stringent regulations and safeguards for the protection of the public." After a long debate the House indorsed the Report of the Select Committee by voting the Third Reading of the Aberdeen District Tramways Bill. $\dagger$ But

* Hansard's Parliamentary Debates, February 27, I877, p. I082 and following; April 23, p. 1672; May II and June 28; and February 5, 1878 , pp. 1038 to 1040.

$\dagger$ Ibid., June I 7, I878, p. 1574 and following, and I606; May 27, p. 747 ; and April 15, p. I275. 
when that Bill reached the House of Lords, that body rejected the clauses permitting the use of steam power. The Lords acted upon the promise of the Earl of Redesdale, Lord Chairman of Committees, that a Select Committee of the House of Lords should be appointed in the following year, 1879 . He would remind their Lordships that hitherto the question had been mainly confined to tramways in streets and towns; but there were now several schemes for tramways carried along roads in the country. The matter, therefore, now required careful re-consideration, and it was very desirable that there should be full consideration." * $*$

In 1879, the Select Committee of the House of Lords reported in favor of the use, experimentally, of steam or other mechanical power. It also indorsed the "principles" which the Select Committec of the House of Commons, I878, had said should govern the granting of licenses for the use, experimentally, of steam or other mechanical power. These principles were: "The local authorities are competent judges of the policy of encouraging steam on Tramways, and should be at liberty to make such contracts and agreements with promoters as they may deem best for the local interests which they represent. The Board of Trade should have powers to intervene on behalf of the public (I) to pre-

* Hansard's Parliamentary Debates, July 26, 1878, pp. 34 I to 343 and February 20, 1879, p. 150r. 
vent undue pressure being put by local authorities upon promoters ; (2) to prevent bargains being made by which the public may be injured either as residents or as ratepayers. Looking to the novelty of the proposed undertaking, to the greater profits which the use of steam may render possible to companies, and to the possible failure and inconvenience of the use of steam or other mechanical power in frequented thoroughfares, it is desirable (I) to provide for a periodical revision of tolls; (2) to provide for the cessation, at the end of seven years, of the contract or agreement under which the use of steam or other mechanical power may be sanctioned, so that at the end of that and of recurring periods of like duration the concession should either absolutely terminate or be so modified and generally revised as the experience gained may seem to require."*

In the House of Commons, Mr. Arthur Peel, who had been Chairman of the Select Committee of 1878 , and had served in $187 \mathrm{I}$ to 1873 as Parliamentary Secretary to the Board of Trade, said: "The local authorities might be not unfairly assumed to be the best judges of the interests they were elected to maintain. The Committee (of 1878 ) were of opinion, therefore, that the local authorities should be able

* Report from the Select Committee on Tramways (Use of Mechanical Power) Bills, I878, p. iv; and Report from the Select Committee of the House of Lords on Tramways, 1879, p. v: "There should be freedom of contract between the Local Authority and the Promoters as to contributions to local rates, fares, tolls, and general charges, subject to an appeal to the Board of Trade." 
to make what contracts they pleased with the promoters who wished to institute steam tramways in any particular district; but they also thought that the public might be protected against the promoters on the one side and the local authorities on the other. The local authorities, for instance, might in some cases, be disposed to levy such an amount of blackmail from the promoters of steam tramways as would materially interfere with the undertaking. On the other hand, the local authorities (that is, the city officials as individuals) might be promoters themselves, or might be induced to make such a bargain with the promoters of the tramways as would be prejudicial to the public interests. The Committee, therefore, said that if there was anything in the contract which made it objectionable to the inhabitants, the Board of Trade should be constituted friends of the public, and should be able to step in and see whether the terms of the contract militated either against any particular interest, or against the interests of the place in general. He knew very well that there had been in past times a feeling in that House against tramways altogether. When horse tramways were started, there was a strong feeling against them, but he thought the time had now passed when horse tramways were regarded as objectionable. Under all the circumstances he thought the House ought to be very careful as to prohibiting entirely the intro- 
duction of steam tramways ... steam tramways would very much reduce fares." *

The Government, however, introduced no Bill to limit the power of veto of the local authorities, or to make the Board of Trade the arbitrator between the local authorities and the promoters, in questions involving the terms upon which the use of steam or other power should be allowed. 'The local authorities retained full power to say whether, and upon what terms, steam or mechanical power should be used. The result was the complete abandonment of that part of the policy of the Tramways Act of I870 which said that the profits of the tramway companies should be in no way limited, in consideration of the facts that the charters were limited to twenty-one years and provided for compulsory sale at structural value.

All Provisional Orders authorizing the use of mechanical power contain the provisions that at any time after three years after the opening of the Burdens placed tramways, the local authority, or upon Street twenty inhabitant ratepayers, may Railways ask the Board of Trade for a revision of fares (tolls). Upon such request being made, the Board of Trade may appoint a referee who shall report in writing. If the referee shall report in favor of revision, the Board of Trade shall fix

* Hansard's Parliamentary Debates, June 17,1878 , p. 1577 and following. 
the fares to be charged, such fares to remain in force until revised by the Board of Trade.

Many Provisional Orders granted in 1879 and the subsequent years contain clauses compelling the companies to give the local authorities one-half of their profits in excess of a certain rate, say to per cent or 15 per cent.* Some companies have submitted to such terms, and upon applying, a few years afterwards, for permission to extend their lines, they have been obliged to lower the limit in question from, say, I2.5 per cent to I I per cent. $\dagger$

The Burnley and District Tramways Order, 1879 , contains the provision "that if in any years the Promoters have declared a dividend upon the capital invested of 6 per cent, the local authority shall have power to call on the Promoters to build 'certain specified extensions." Other Provisional Orders contain clauses giving the local authority power to call upon the company at any time to build extensions. In such cases, the Board of Trade is to act as referee, or is to appoint the referee. $\ddagger$

Provisional Orders often contain clauses empowering the local authority to purchase the tramway at the expiration of five, ten, or some other number of years, after the opening of the line. In such cases it is usually provided that the price shall be fixed

* The Leamington and Warwick Tramways Order, 1879, and The Derby Tramways Order, 1879.

t The Leicester Tramways (Extension) Order, 1884.

$\ddagger$ The Shipley Tramways Order, 1885 . 
by arbitration under the Land Clauses Consolidation Act, I845 - that is, with allowance for compulsory sale. But the Paisley Tramways Order, I885, gives the local authority power to purchase ten years after the opening of the line, on the basis of paying "the amount of the original cost of the construction of the tramways and all lands and buildings" and the market value of the rolling stock, horses, and other perishable equipment.

The Swansea Tramway Order, 1879 , provides that the promoters shall not begin the building authorized by the Order until they shall have paid to the Borough the sum of $\$ 2000$ toward widening a certain road upon which the tramway is to be built.* Again, the Lea Bridge, Leyton, and Walthamstow Tramway Act, r884, binds the company, "before opening a section of its line for traffic, to defray the main cost of widening part of the road, an improvement desired and debated by the Local Board of Works long before the tramway was proposed." $\dagger$ Oftentimes two or more of the foregoing disabilities will be put into a Provisional Order.‡

Frequently a local authority will try to put into the Provisional Order such provisions that the Board of Trade will be obliged to warn the local

* Report by the Board of Trade of their Proceedings under "The Tramways Act, I870," and "The Gas and Water Facilities Act, 1870," during the session of $1879, \mathrm{p} .5$.

$\dagger$ F. Clifford: History of Private Bill Legislation, Vol. I, p. 19r.

‡ The Derby Tramways Order, 1879 . 
authority that either the Chairman of Committces of the House of Commons or the Chairman of Committees of the House of Lords will disallow the provision in question as being "against public policy." For example, in 1879 , the Borough of Derby tried to insert a clause compelling the promoters to purchase "the omnibus undertakings and plants of the various public and private omnibus proprietors in the Borough." * Again, in the Edinburgh Northern Tramways Bill, I884, the municipalities of Edinburgh and Leith, as the price of their assent to the Bill, required, among other things, the payment by the company of a way-leave, rising by yearly graduations to $\$ 500$ per mile per annum. This provision passed a Committee of the House of Commons but was struck out in the House of Lords as being "contrary to public policy." $\dagger$

Oftentimes provisions that would be disallowed by one or the other Chairman of Committees are made the subject of private bargains between the local authorities and the promoters. For example, before the Joint Select Committee on Municipal Trading, I900, Mr. Murphy, one of the largest builders of tramways, said: "I am paying rent for way-leave in some undertakings I have got in England this year. Parliament, I know, objects to it and will

* Report by the Board of Trade on their Proceedings under "The Tramways Act, 1870," and "The Gas and Water Facilities Act, 1870," during the session of 1879 , p. 5 .

$\dagger$ F. Clifford: History of Private Bill Legislation, Vol. I, p. I9г. 
not sanction it in Private Bills. The Earl of Morley (since r889 Chairman of Committees of the House of Lords) set his face against it and will not have it, but it is done by private agreement between the companies and the local authorities." *

Mr. Hobhouse, a member of the Joint Select Committee of I900, said, "Speaking as Chairman of a Private Bill Committee, we are sometimes told by counsel that companies are in honor bound to carry out the things which are struck out of the Bill." And Mr. Albert Gray, Counsel to the Chairman of Committees of the House of Lords, added that the driving of bargains such as are here under discussion "probably must lead to corruption in some form or other, because we have this state of things: An agreement is made between a company and a local authority that a rent must be paid. If the Lord Chairman, or the Chairman of Ways and Means in the House of Commons, directs the clause to be struck out, it is struck out, but the agreement, the contract, remains, and the company may pay this rent, or if they do not pay it in the form of a rent, they may pay it in some other form, and perhaps it does, or perhaps it does not, get into the municipal accounts. I know not what happens to it." $\dagger$

That local authorities have the means of enforcing

* Report from the Joint Select Committee on Municipal Trading, I900, q. I5 18; compare, also, q. $305^{8}$ and 3954 .

† Ibid., 1900, q. 714 and $34 \mathrm{r}$. 
agreements that have been disallowed is shown by the following incident. A tramway company had obtained an Act of Parliament authorizing the conversion from horse traction to electric traction. When the company took steps to increase the radius of the curves at street corners, in order that electric cars might pass over the curves, the municipality demanded a contribution of $\$ 100,000$ toward the cost of widening the streets, not only at the turnouts in question, but also at other places. The municipality argued that the company was proposing to occupy more space in the streets than it had been occupying. The matter was taken to court, and was referred to the Board of Trade for arbitration. But before the arbitrator was appointed, the Mayor approached the chairman of the company, with the words: "It is in our power to give you this trouble every time you come to us; is not it worth while to settle?" Before the Joint Select Committee on Municipal Trading, I900, the chairman of the company said: "In order to settle and dispose of that matter, the company agreed to the payment of $\$ 25,000$, which I regard as a very improper payment, but as a commercial transaction the directors decided that it was cheaper to do that than to have the constant harass and worry of litigation every time we wanted to make a small alteration for which consent might be necessary." *

* Report from the Joint Select Committee on Municipal Trading, 1900, q. I203. 
Mr. W. M. Murphy, who had built tramways in England, Scotland, Ireland, and on the Continent, said: "Sometimes they make the terms so onerous that one has to abandon the project. I have had to do that in more than one instance." In reply to the Chairman's request for a specific instance, he said: "I was promoting a line this year on the north side of the Clyde, and the town of Dumbarton wanted such terms that I abandoned the thing. ... I I may say it was one of those enterprises which are of very doubtful value. Dumbarton is a small place (population, $\mathrm{r}_{5}, \infty 00$ ) coming to the size of a town, where it is doubtful whether tramways will pay, and in addition to the ordinary terms as to the paving of the streets, they wanted a large block of buildings taken down at the corner of a street, which would not pay." * In December, 1904, Dumbarton still was without street railways.

Mr. S. Morse appeared on behalf of the London Chamber of Commerce, being the chairman of that body's Committee on Municipal Trading. He said: "I have had a large experience in dealing with local authorities in these matters, and what I find is shortly that (of course I am speaking generally) they do not consider the matter purely on the question as to whether the proposed questions are desired in the public interest or not; they apparently consider

* Report from the Joint Select Committee on Municipal Trading, I900, q. I 5 I 7 to I 53 I. 
it from the point of view that their consent is made by the Tramways Act, 1870 , the condition precedent to the grant of any powers, and it is for them therefore to hang conditions on to the fullest extent possible. I have a case in mind which I may perhaps mention of a very important town where I was present on behalf of a tramway company at a neeting of a very large council in committee. The chairman of the committee was the ex-mayor and there was a very full attendance, and he put it quite frankly. He said: 'Gentlemen, these promoters have to obtain our consent; and I suggest to you that we should get the very best terms we can;' in fact, he used the expression, 'We should bleed them.' I am not quarrelling with it, I am merely giving it as a fact which has come before me professionally .... We were proposing to spend $\$ 5, \infty 00, \infty 00$ in buying up tramways in an important district, making them electrical and a complete scheme; we had settled everything practically with every local authority, including this one, except that they claimed to supply the electrical energy (from their municipal light plant) with whick to work the tramways at a price which we found was prohibitive, with the result that we had to withdraw our Bill."*

Mr. E. Garcke, who was Managing Director

* Report from the Joint Select Committee on Municipal Trading, I900, q. 786 . 
of the British Electric Traction Co., with assets of $\$ 8,280,000$, as well as a director in twenty-five other traction companies, said: "It is almost a truism to me that a municipal corporation having an electric lighting plant is most anxious to take up electric tramways for one of two reasons: either because they have made a profit on their electric lighting, and they argue we shall not make a mistake in taking up electric tramways, . . . or else they are anxious to do it for this other reason - that, having made a loss upon electric lighting, they are very anxious to obtain electric tramways in order to largely increase the demand for their electricity... . Then I have several instances in my mind where local authorities have not entered upon electric lighting, although they have obtained Provisional Orders, because they have felt nervous as to whether the demand in their town would be sufficient; but directly I come before them and say, 'Gentlemen, will you give me a concession for an electric tramway?' (probably I own the horse tramway in their town), they say: 'Then you will become a customer for electricity. If we give our consent to convert this line to electric traction, will you buy your electricity from us, if we put up a plant?' I have had several cases where I have made that arrangement, and I have had to wait for the electricity for my tramways until the local authorities have been able to establish their electric lighting undertaking, 
which I have very good authority for saying they probably would not have established but for the prospect of receiving a very large customer in the shape of the tramways."

Mr. Garcke continued: "I might mention another form of Municipal Trading which has come under my direct knowledge. . . . I am interested in the development of a very large electrical traction scheme in South Staffordshire, and there is also a company undertaking the supply of electricity over the whole of the same area. . . . I, or rather my representative, went to some of the local authorities in that district for their consent to convert the present steam tramway to electric traction, and the (municipal) corporation officials, or some of the members of the council, suggested that we should purchase the electric current from their council for the purposes of our tramways. Our representative replied, 'But you have not got a power plant, and are not likely to have one, because you are in treaty with the (electricity supply) company to take your current from that company in bulk.' They said, 'But we can buy that current from that company and sell it to you at a profit." *

Mr. Garcke also testified that he was interested in a large company which had purchased the horse tramways of Wolverhampton (94,000 inhabitants)

* Report from the Joint Select Committee on Municipal Trading, 1900, q. II 7 and II76. 
and of many adjoining towns, for the purpose of welding them into a huge electrical system. When the company applied for consent to convert the Wolverhampton tramways to electrical traction, the city insisted upon the company taking its current from the municipal light plant. The company refused to comply, first, because the price asked for current was "very exorbitant"; second, the company had power plants from which to supply its whole system, of which the Wolverhampton tramways formed only a part. Thereupon the city, under the Tramways Act, I870, purchased that part of the Wolverhampton tramways that lay within the city limits, 5.75 miles, out of a total of 10.5 miles. The company asked the city to buy the remaining 4.75 miles lying outside of the city limits, at a price proportionate to that paid for the lines within the city. The chairman of the committee of the town council replied: "No, we will not pay the same rate for the outside lines, because they are useless to you, or will become useless to you when we have bought the lines inside, and you will have to come to us, cap in hand, and ask us to take them off your hands." Mr. Garcke added: "The lines outside the borough of Wolverhampton would have become derelict but for the exceptional circumstance that another company was able to buy them and tack them on to another system, and that company agreed to pay the same proportionate price for these outside lines as 
the corporation of Wolverhampton paid for the inside lines." *

In July, I90I, the Earl of Morley, Chairman of Committees in the House of Lords from 1889 to 1904 , stated that within a year or two after the enactment

Standing Order No. 22 extends Municipal Veto to Private Charters of the Tramways Act, 1870, each House of Parliament had made it a Standing Order - No. 22 - that no Private Bill Committee should consider an application for a Private Tramway Act, unless the promoters of the Act proved the consent of the local authority concerned. In that way the absolute veto given the local authorities in the case of Provisional Orders to be issued by the Board of Trade under the Act of 1870 , had been extended also to Private Bills asking for street railway charters. The Earl of Morley then stated that in I900, he, and the Chairman of Committees in the House of Commons, and Mr. Chaplin, who, as President of the Local Government Board, was then in charge of the Government's "Housing of the Working Classes Act, I890, Amendment Bill, I900," had agreed that the Standing Order No. 22 ought to be amended so as to allow the Private Bill Committees to examine whether the local authorities had withheld their consent unreasonably. If the Private Bill Committees should conclude that consent had been unrea-

* Report from the Joint Select Committee on Municipal Trading, 1900, q. II 99 to I 205. 
sonably withheld, they should so report to Parliament, which would then decide whether the consent should be dispensed with. The Earl of Morley added that in July, I900, Mr. Chaplin had said, in the debate on the Third Reading of the Housing of the Working Classes Bill: "After a conference with the Chairman of Committees in both Houses, I am in a position to say that the Government are willing to make such alterations in that Standing Order and propose them in due course, as will modify these restrictions and allow the question to be brought before Parliament and leave to the Committee the decision as to whether the matter should go forward or not." * Finally, Lord Ribblesdale, speaking on behalf of the London County Council, in August, I900, had asked him (the Earl of Morley) in the House of Lords, whether the Standing Order No. 22 could not be modified. The London County Council itself, Lord Ribblesdale had said, had been stopped from building tramways, through inability to get the consent of other local authorities. $\dagger$

In accordance with the foregoing understandings and representations, the Earl of Morley, early in I90r, had given notice that he would move an amendment to Standing Order No. 22. But on July II he informed the House that he would not proceed

* Mr. Chaplin's statement will be found in Hansard's Parliamentary Debates, July i 2 , i900, p. I4 18.

† Lord Ribblesdale's statement will be found in Hansard's Parliamentary Debates, August 2, I900, p. 405 . 
with his motion. The London County Council had changed its mind; and "he had found, as the Session went on, that there was little or no intention of moving the proposed amendment in the House of Commons. It would be useless to amend the Lords' Standing Order, unless the Commons' Order were amended at the same time. Therefore he would drop the matter for the time being." He added, "But I feel very strongly about it, and if I get any sympathy here or elsewhere (in the House of Commons), I shall be very glad to reintroduce the matter."

The Earl of Morley set forth at great length his reasons for desiring the amendment of Standing Order No. 22, speaking from the knowledge gained by his scrutiny of all the tramway Provisional Orders and Private Bills that had been enacted since 1889 . He gave numerous striking illustrations of the manner and spirit in which the local authorities either had sold their consent, or had withheld it entirely. Only one, however, shall be here produced. He said: "This has actually happened in London within the last year. A tramway company got its bill consented to by one of the London municipalities through whose area it was to run, and immediately afterward it went for the consent of the London County Council - which was only remotely interested, and only interested as the owner of a (competing) tramway in another part of London, and they refused their consent." 
The Earl of Morley concluded as follows: "My reasons, if I may be allowed to recapitulate them, are these: that it is not theoretically right that any one or any body of persons should have an absolute power of veto and should be able to prevent a scheme coming in any shape before Parliament against their will; that it is against the principles of modern legislation, especially against the principles of the Light Railways Act; that it is not right for rival proprietors (as it is in the case of large municipalities) to have the power of absolutely stopping any rivals from coming into the field; that there is an inconvenience in the double veto of the road authority and the local authority, and, above all, that it is not expedient or in the public interests that you should give to the local authorities such a strong power of exacting conditions that may be very onerous upon an important national industry, and also that you should encourage the promoters of these undertakings to bribe the local authorities in some way or other. When I use the word 'bribe,' I desire distinctly to explain that I do not mean money bribe, I mean bribing by offering some advantage in order to get the consent of the local authority." *

Mr. Chaplin, shortly after carrying through Parliament the Housing of the Working Classes Bill, I900, resigned the office of President of the Local Government Board, and withdrew from the Salis-

* Hansard's Parliamentary Debates, July Ir, Igor, pp. 3I to 42. 
bury Ministry. In May, 190 I, he asked the First Lord of the Treasury, Mr. A. J. Balfour: "If his attention has been called to the difficulties which arise, under Standing Order 22, in the making of tramways in London in order to facilitate the housing of the working classes; and whether, having regard to the pledges which were given by the Government in relation to that subject during the last Parliament, the Government propose at an early opportunity to take measures to give effect to those pledges?" In reply to Mr. Balfour's statement, "I am not aware of any specific pledge, ..." Mr. Chaplin added: "Is my right honorable friend not aware, or has he forgotten, that in the Third Reading of the Working Classes Bill, and with the sanction of my colleagues, I gave such a pledge on behalf of the Government myself?" *

One year later, in May, 1902, Mr. Chaplin moved an amendment to Standing Order 22, giving the Private Bill Committee power to examine whether the consent of the local authority had been unreasonably withheld, and to report accordingly in the event of unreasonable withholding of consent. He said improved means of locomotion were absolutely essential to giving effect to the Housing of the Working Classes Act, 1900. "There is no doubt in the world that the extension of the tramway system is a matter of the first importance in connection with * Hansard's Parliamentary Debates, May 20, I901, p. 609. 
the great problem of the housing of the poor. At the same time, this extension, as matters stand now, is hindered, hampered, and checked by the existing provisions of the Standing Order, or by the action taken by certain local authorities under it, to a degree which few people are aware of. . . . What the local authorities would describe as conditions, are regarded by the promoters, and very often no doubt, with good reason, as neither more nor less than blackmail. I could give many instances to show to what extent that has been carried on. This has been the subject of great complaint for years, to which I may say that no one is more alive than the Chairman of Committees, both in this and the other House of Parliament, and I do not think that I should be going too far if I said that on several occasions it has led to considerable scandals." *

Mr. J. W. Lowther, who, since 1895 , had held the office of Chairman of Committees by virtue of being Chairman of the Committee of Ways and Means, said: "We have heard something of blackmail to-night by certain local authorities. I do not think it necessary to go into that, although I dare say that if we were to examine very closely some of the Bills which have been before Parliament during the last few years, we might find cases to which that term would not be wholly inapplicable." Mr.

* Hansard's Parliamentary Debates, May 15, 1902, p. $43^{8}$ and following. 
Lowther added that it was a serious objection to the amendment that the abolition of the local veto would involve the local authorities in the expense of defending before the Parliamentary Committees their objections to the granting of street railway charters; but that there were still greater objections to leaving matters in their present state. He concluded with the words: "Although I object on the score of expense, I think the balance lies in favor of the change proposed by my honorable friend, and if he goes to a division, I shall support him in the lobby."

Sir Albert K. Rollit, at the request of the Municipal Corporations Association * led the opposition to the amendment. He rested his case upon the argument that the municipalities would become involved in great expense by the necessity of appearing against the numberless applications for charters that would follow the repeal of the veto of the local authorities.

Mr. Goddard expressed sentiments that have many adherents in the Municipal Corporations Association. He said: "The object of the amendment must be to increase the number of private enterprises in boroughs and towns. Now was that a desirable end to attain? Sooner or later all these great schemes would have to be bought out by the local authority, and any local authority which had had

* This association in 1905 had a membership consisting of 296 municipal corporations. 
any experience in having to buy out these kinds of enterprises would know something of the difficulties and the great expense they were put to in regard to such purchases. He did not think they ought to open the door wider to this kind of private enterprise, and for those reasons he should vote against the amendment."

Mr. Chaplin was obliged to withdraw his amendment.

From 1878 to 1895 the net earnings of the tramways of the United Kingdom averaged 5.2 per cent upon the capital invested. In no year did they rise to 6 per cent, and in five years only did they reach 5.5 per cent.* Those net earnings had to provide for sinking fund and depreciation charges, as well as for the interest on the capital invested. It is clear beyond the possibility of controversy that the tramway industry afforded no margin of profit that could carry the extortionate practices by the local authorities from motives of greed.

The responsibility for the sanction given by the Parliamentary Select Committees of 1878 and 1879 to the policy of municipal trading in street railway The Bureaucrat franchises, rests largely upon the late versus the Men of Lord Farrer, who entered the Board Affairs of Trade sometime about I846, shortly after having been graduated from Balliol

* Board of Trade Return of Street and Road Tramways Authorized by Parliament, showing the Amount of Capital Authorized, Paid up, and Expended; etc., annual issues. 
College, Oxford; was made assistant Secretary of Marine Department of the Board of Trade in $185^{\circ}$; was Permanent Secretary to the Board of Trade from 1873 to 1886 ; and, in 1893 , was raised to the Peerage "for public service." Lord Farrer had much influence in shaping legislation on all matters within the province of the Board of Trade; and "even in matters not within his own department, he was constantly resorted to by the government for information and advice." *

In 1878, Mr. Farrer testified as follows before the House of Commons Select Committee: "And it appeared to the Board of Trade and to the authorities of the House that if you are going to give to these tramway companies what will really be a very valuable privilege to them, something which, according to their own statements, will enable them very largely to increase their dividends, you ought, at the same time, to make provision that, in some form or other, the public shall get a considerable portion of that advantage." Mr. Farrer then stated that, in 1877 , Mr. Hopkins, the engineer of the North Metropolitan Tramway Co., had testified that the use of steam would enable the company to save 4 cents per car mile on the traction charges. That saving, Mr. Farrer said, would raise the dividends of the North Metropolitan Tramway Co. from 8.5 per cent

\footnotetext{
* Sir Robert Giffen's introduction to T. H. Farrer: The State in its Relation to Trade.
} 
to about I 3 per cent. "I do not vouch for the particular figure, but I merely use this as an illustration. If that is so, we think that certainly in some form or another, the public ought to share in the advantage of that saving. . . . The companies will, of course, tell you that with that saving they will give the public additional facilities. We do not always find that when undertakers have a monopoly of a public enterprise, they give the public the benefit of all the savings that they may make; they are apt to put it, and very properly, into the pockets of their shareholders. Therefore, now that the thing is going to be allowed for the first time, this is the proper time at which to make conditions with the companies." *

As the permanent head of the Board of Trade, Mr. Farrer had abundant opportunities for informing himself as to the profitableness of street railways. But as chief witness before the Select Committee he selected one of the most profitable lines in Great Britain and contented himself with showing, by a very superficial calculation, that the use of steam power would increase the profits of the company from $8 \frac{1}{2}$ per cent to about $\mathrm{I} 3$ per cent. He did not even raise the question whether the use of steam would increase the wear and tear upon the permanent way, necessitate the re-building of the roadbed, and thus counteract in part the saving to be made in the traction charges.

* Report from the Select Committee on Tramways Bills, I878, q. I7 and following. 
A few months after Mr. Farrer had testified, the Board of Trade issued an annual return* which showed that in the year ending with July, 1878 , the net receipts of the tramway companies of the United Kingdom had averaged barely 5.5 per cent, and that many companies had barely earned operating expenses.

Mr. Hopkins, engineer to the North Metropolitan Tramway Co., the Liverpool Company, the Dublin Company, and companies in other British cities, testified before the Select Committee of 1878 that his statement made in 1877 , that the use of steam would enable the North Metropolitan Co. to save 4 cents per car mile, was based on the knowledge that Messrs. Hughes \& Co., the owners of a patented tramway engine, had made a contract to move the cars of the Vale of Clyde Steam Tramway Co. for I 1.5 cents per car mile. He added that since he had made that statement before the Select Committee of 1877 , Messrs. Hughes \& Co. had told him that they were losing money on the contract, which they had made because they were very anxious to obtain the first contract in the United Kingdom as an advertisement and as an introduction to other companies. $\dagger$

* Board of Trade Return of Street and Road Tramways Authorized by Parliament, showing the Amount of Capital Authorized, Paid up, and Expended; etc.

$\dagger$ Report from the Select Committee on Tramways Bills, 1878, q. 890 and 45 I to 453 . 
In striking contrast to the testimony of the Permanent Secretary to the Board of Trade was the testimony given, in 1878 , by the men who were establishing the new industry of street railway building. To Mr. Alexander Wood, M.D., Chairman of the Edinburgh Street Tramway Co., the Chairman of the Select Committee put the question: "Do you disapprove of the proposal to tax mechanical power on the tramways in the same way as railroads are taxed" (a tax of 5 per cent on passenger receipts)? Mr. Wood replied: "I think that it would be a pity in the infancy of the tramways to discourage them in any way. I think they require encouragement more than discouragement; if they are to be taxed, I think that the tax ought not to go to the road authorities, but should go to diminish the fares."

In I 870, the Lord Provost of Edinburgh had called a meeting of the citizens of Edinburgh to consider the question of improving the housing of the poorer classes, asking Mr. Alexander Wood to preside. Mr. Wood and Mr. Cowan, upon further investigation, had concluded that the way to deal with the overcrowding of the poorer classes was to spread out the city. At that time Edinburgh had 196,500 inhabitants, of whom no less than 3 I,4I6 lived in the condition of 3 to ro people in one room, while another $35,8{ }_{1} 3$ lived in the condition of 5 to ro persons in two rooms. Mr. Wood and Mr. Cowan, after in- 
specting the only tramways then in operation in Great Britain, - those of Birkenhead, Liverpool, and London, - had organized a company for the building of tramways in Edinburgh for the express purpose of curing this evil, by decentralizing the population.

Mr. Dillwyn Parrish, a contractor, who had built the Liverpool tramways, the Dublin tramways, and the North Metropolitan tramways, appeared before the Select Committee of 1878 , and said that on steep grades where more than two horses were required, steam power was economical; on a level road where one horse would answer it was not economical ; and it depended on the special circumstances of the case whether it was economical on a level road where two horses would answer.*

Mr. Barfoot, Chairman of the Leicester Tramways, supported the testimony of Mr. Parrish. He said he proposed to use steam only for the purpose of joining Leicester with the outlying manufacturing villages, which could not profitably be reached by means of horse tramways. $\dagger$

Mr. Richardson, Chairman of the North Metropolitan Co., as well as of the Dublin Co., expressed the opinion that there was no great saving in the use of steam for ordinary traffic, but that steam was valuable in meeting sudden and short demands for

* Report from the Select Committee on Tramways Bills, x878, q. 1237 to 1252 .

† Ibid., I878, q. 226 and following. 
exceptional transportation facilities. A tramway company could keep steam engines in reserve for such occasions; but it could not keep a stud of horses for such occasions, for the horses would eat off their heads.*

The Select Committees of Parliament and Parliament itself indorsed the views of the bureaucrat and rejected the arguments of the men of affairs.

In 1877 the first cable street railway was opened in the United States. In 1890 , there were 55 such systems, with a route mileage of 283 miles, and a track mileage of 488 miles. $\dagger$ By 1902 more than one-half of them, with a track mileage of 248 miles, had been discarded as antiquated.

In I882, the British Parliament confirmed the first Provisional Order authorizing the use of the cable, and in 1883 , it authorized nine such orders. But in 1890 , there were in operation in the United The Cable System, Kingdom not to exceed 8 miles of like Steam, not cable street railway. In 1897 and used on British the subsequent years, long after the Tramways cable had been abandoned in the United States, the city of Edinburgh built some 22 miles of cable railway. $\S$

* Report from the Select Committee on Tramways Bills, I878, q. 632.

+ Report on Transportation Business $n$ the United States at the Eleventh Census: I890, Part I; and United States Census: Bulletin 3.

$\mp$ Report by the Board of Trade on their Proceedings under "The Tramways Act, I870," etc.; I882 and I883.

$\S$ Board of Trade Return of Street and Road Tramways authorized by Parliament, etc., I902; The Municipal Year Book, I899, p. 444; and Duncan's Manual of Tramways, Omnibuses, and Electric Railways, Igo4. 
The failure of the cable system to get a foothold in Great Britain was due in part to the fact that from 1879 to 1896 authority to use mechanical power was given for periods of seven years only; in part it was due to the fact that the life of franchises was limited to twenty-one years and ended with compulsory sale on the basis of the value of the materials embodied in the plant. On those terms, capitalists, with unimportant exceptions, were unwilling to incur the enormous outlays of money demanded by the cable system of traction.

In $188 \mathrm{I}$, the firm of Siemens Bros. \& Co., of Berlin and London, built the first electric railway, that from Berlin to Lichterfelde. In $188_{3}$, the same firm built an electric railway and tramway in the northern part of Ireland, from Portrush to Bushmills.* In that same year a short electric tramway was opened at Brighton Beach, a watering place near London. In I884, the municipality of Blackpool built a short electric line. In $\mathrm{I}_{88}$ and $\mathrm{I} 886$, two further electric lines were built in Ireland and on the Isle of Wight, respectively. From 1887 to I 889 , electric railway building was suspended. In I 890 to 1895 , nine lines were built. At the close of 1895 , when tramway building by companies under the Tramways Act, I870, may be said to

* Report from the Joint Select Committee on the Electric and Cable Railways (Metropolis), 1892 , q. 672, WV. H. Pierce, Engineer in Chief to the Post Office Department. Compare Report from the Joint Select Committee on Municipal Trading, 1900, q. 1650. 
have come to an end, there were in the United Kingdom fourteen electric tramways, with a route mileage of not to exceed 65.5 miles, and a track mileage of not to exceed I 35 miles. Of those tramways, not less than five, with a route mileage of 26 miles lay in Ireland and the Channel Islands, territory to which the Tramways Act, I870, does not extend. A sixth tramway, the Liverpool Overhead, an elevated railway, with a route mileage of 6.75 miles, and a track mileage of 13.50 miles, also was beyond the reach of the blighting Act of 1870 .*

In the United States, there were no permanently successful electric tramways in operation in 1885 . Two permanently successful tramways were opened in $\mathrm{r} 886$; six in $\mathrm{r} 887$; thirty in $\mathrm{r} 888$; fifty-seven in $\mathrm{r} 889$, and forty-nine in the first six months of 1890 . On June 30,1890 , there were in operation in the United States 144 electric tramways, with a route mileage of 914 miles, and a track mileage of 1262 miles. $\dagger$

There were two reasons for the failure of the electric tramway to get a foothold in the United Reasons for Fail- Kingdom in the period from $188_{3}$ ure to develop to 1895 . The first was the comElectric Tram- pulsory purchase clause in the Tramways

ways Act, 1870 . The second was the complete paralysis in the United Kingdom of the

\footnotetext{
* Garcke: Manual of Electrical Undertakings, issues of 1898-99 and I904.

$\dagger$ Report on Transportation Business in the United States at the Eleventh Census: I89o, Part I.
} 
electric lighting industry, in the period from 1882 to $\mathrm{I} 888$. That paralysis prevented the British electrical engineer from acquiring practical experience in the art of transmitting electrical energy over long distances without such loss of energy as would make unprofitable the application of electricity to street railway traction.

As for the paralyzing effect of the Tramways Act, 1870 , the municipalities now themselves admit that electric tramways cannot be built under twentyone-year-compulsory-sale franchises, though they are not willing to permit the amendment of the Act of 1870. In response to the demands of the Association of Municipal Corporations, both Houses of Parliament in I90 I amended their Standing Orders in such way as to allow a municipality that wished to build a tramway into the territory of an adjoining municipality to obtain, by means of a Private Bill, a franchise for a period not exceeding forty-two years. Up to that time, the Standing Orders had limited such franchises to a maximum of twenty-one years. Mr. J. W. Lowther, Chairman of Committees in the House of Commons, in moving the amendment to the Standing Order, said: "It has been found, especially in the case of electric tramways, that twenty-one years is not a sufficient period. Engineers put the life of an electric tramway at forty-two years, and we propose to amend the Standing Order 
accordingly. Of course, forty-two years will be an outside limit. ... In 1870 , when the Tramway Act was passed, twenty-one years was taken as the life of a tramway. At that time only horse tramways existed, but at the present time many corporations (i.e. municipalities) are laying down electric tramways (in the territory of their neighbors), and the expense connected with the installation of these is so large that it has been found not to be worth while to lay them down unless for an extended period. If they have to sell them at the end of twenty-one years, they are losers by the transaction."*

As for the second factor that prevented the electric tramway from getting a foothold in the United Kingdom in the period from $\mathrm{I}_{88}$ to 1895 , this was the situation. In $\mathrm{I} 88 \mathrm{I}$, British capitalists, representing millions of pounds sterling, stood ready to support the leading British engineers in exploiting the incandescent electric light, which had just then been perfected to the point of becoming available for use on a commercial basis. There was, it is true, some question whether it would be possible to transmit current over long distances without undue loss - in other words, whether it would be commercially possible to install electric power plants that should furnish light over large

* Hansard's Parliamentary Debates, March I5, I90I, p. 45 and following. The corresponding motion, made by the Earl of Morley, Chairman of Committees in the House of Lords, will be found on p. Ig8, March I8, I901. 
areas. But British engineers and capitalists were not only ready, but anxious, to try the experiment. Indeed, the Swan Company, as well as the British Edison Company, on the strength of six months' licenses, in $\mathrm{I} 88 \mathrm{I}$, built power plants in London and lighted certain streets, as well as the shops and offices in those streets.

The British capitalists and engineers asked Parliament not to repeat the mistake of 1870 . But the municipalities in the past years had invested heavily in gas plants; and they now feared that the electric light would seriously impair the earning power of their municipal gas plants. They were well organized, and aggressive; and they had a powerful friend in Mr. Joseph Chamberlain, President of the Board of Trade. Mr. Chamberlain, it will be remembered, had begun his political career as a champion of municipal trading, particularly in gas, partly because he held that the profits to be made from municipal trading would diminish taxation, partly because he desired to magnify the office of the municipal politician.

Under pressure from the municipalities, Parliament, in 1882 , inserted in the Electric Lighting Act the twenty-one year compulsory sale clause of the Tramways Act, 1870. At the close of I888, there was in the United Kingdom no chartered electric light company that used the streets for the purpose of distributing current for power or for 
incandescent light. In the long period from 1882 to 1888 , the British engineer was denied the opportunity to solve, by practical experience, the problem of transmitting electrical energy over long distances, without undue loss. For the solution of that problem, the experience gained in operating the large number of plants installed by theatres, hotels, department stores, warehouses, factories, and mills, helped him not.

In the meantime, in the United States, there were opened in I88I to I885, no less than 167 central electric stations which distributed current for power and for light. In I886, there were opened Io0 such central stations; in 1887 , there were opened 147 ; and in I888, there were opened 160.

When the American engineer, backed by the American promoter and captain of industry, took up, in I886, the problem of applying electrical power to street railway traction, he could draw on the knowledge and experience gained in the building and operating of 167 central electric stations - knowledge and experience augmented in the two years 1886 and 1887 , by the building and operating of 247 additional central electric stations.

The American promoter and captain of industry had a further great advantage in the fact that the existing horse railways, as a rule, had very longlived charters, fifty, ninety-nine, and nine hundred and ninety-nine years being the most common 
period for which charters had been granted. Those long-lived charters made it possible for the American promoter to obtain capital for the hazardous experiment of converting horse railways to electric railways - an experiment that could not succeed unless the application of electricity should increase enormously the street railway traffic. The existing horse railways had to be re-equipped and rebuilt. The electric motors were too heavy for the old cars, and the latter had no selling value; the use of heavy electric cars made it necessary to reconstruct the roadbed and to sell the old rails at "scrap" prices; the old barns and car-houses had to be sacrificed, and fortunate was the manager who could obtain for his horses even onethird their original cost. All electric machinery was very high in price, as well as liable to be rendered useless through further inventions.

It is a matter of record that in the years 1892 to I 896 electrical machinery fell enormously in price, and that the fall entailed heavy losses upon the pioneers in electric street railway building. In I896 the Massachusetts State Railroad Commission stated in its annual report that "a suburban railway, including power plant, which in 1892 cost $\$ 35,500$ per mile of track to build and equip, could be built and equipped in the same manner in 1895 for $\$ 22,600$ per mile of track. Motors formerly costing $\$ 2850$ now can be bought for 
\$850." It is also a matter of record that the Boston Elevated Railway Co., formerly the West End Railway Co., in I 900 was using on its surface cars its fifth equipment of motors, having "scrapped" four equipments in the course of twelve years. It was this heavy fall in prices, together with the necessity of throwing aside equipment before it had been worn out, that led the Massáchusetts Railroad Commission to report, in 1896 , that "the electric railway is not on the whole earning so large a return as did its predecessor, the horse railway. This is as true with respect to the city as with respect to the country railways, taken as a class. . . . Again, take only the older and stronger dividendpaying companies, which have about 87 per cent of the total capital stock. The average dividend paid by these companies was: 7.13 per cent in 1885 , 7.03 per cent in 1890 , and 6.63 per cent in 1895. ." *

* Annual Reports of the Massachusetts Board of Railroad Commissioners, 1896,1900 , and 1903 .

Comparative Results of Horse Power and Electric Power upon the Street RaIlways of Massachusetts

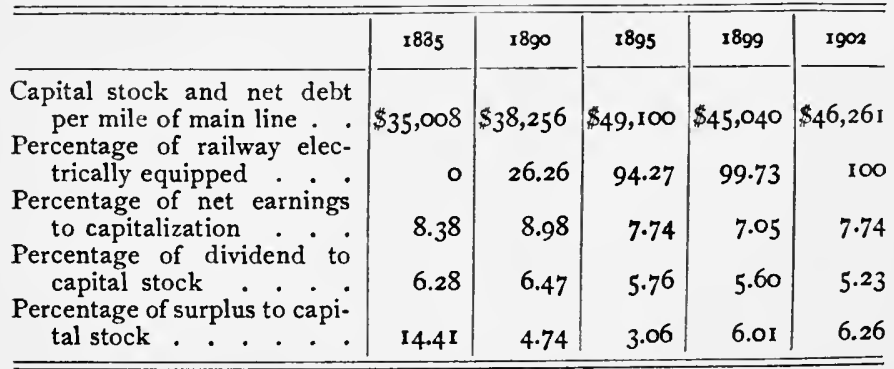


In 1893 this subject of the losses unavoidable in the development of new industries was made the subject of a court record. In the case of $\mathrm{Mil}$ waukee Electric Railway and Light Co. vs. City of Milwaukee, the Circuit Court of the Eastern District of Wisconsin * found that the company had invested $\$ 8,885,644$ in a street railway which, in 1898 , could have been replaced for $\$ 5,000,000$. The difference, $\$_{3}, 88_{5}, 644$, the Court said, represented "preliminary expenditures - cost of acquiring old horse lines, experiments, depreciation in value of material used," etc. The Court continued: "How much of this $\$_{3}, 88_{5}, 644$ may be defined or apportioned as the amount which was both 'really and necessarily invested in the enterprise,' I have not attempted to ascertain, except to this extent: that I am clearly of opinon that at least $\$ 2,000,000$ of these preliminary expenditures are entitled to equitable consideration, as so invested beyond the reproduction value, if the valuation is not otherwise found sufficient for all the purposes of this case, but no opinion is expressed in reference to the remaining $\$ \mathrm{I}, 88_{5}, 644$."

The difficulties and dangers illustrated by these quotations from the experience of the electric street railways in the State of Massachusetts and the City of Milwaukee, were clearly foreseen by the pioneer promoters of electric street railways as

* Federal Reporter, Vol. 87. 
well as by the capitalists to whom these promoters appealed for funds. The promoters and the capitalists were willing to face the difficulties and assume the risks, because the possession of franchises of long life promised the opportunity to recover the losses that were a necessary incident to the development of the new industry. 


\section{CHAPTER III}

\section{THE LIGHT RAILWAYS ACT, I 896}

IN I896, Parliament passed "An Act to facilitate the construction of Light Railways in Great Britain." * That Act was to remain in force for five years, by way of experiment; but since Igor it has been renewed each year. With one exception, presently to be mentioned, the discussion of the Bill was confined to the agricultural depression in Great Britain, and the necessity of affording relief by the building of inexpensive light railways which should give the farming regions better access to the existing railways. Neither the Act of I896, nor any other statute, defines "light railways"; therefore tramways may be built, and are built, under authority of the Light Railways Act, I 896 .

While the Bill was before the House of Commons, Mr. Channing moved that it be amended so as to give the local authorities power to purchase on the terms of the Tramways Act, I870, any tramways that might come to be built under the Light Railways Act. He withdrew that amendment, however, after Mr. Ritchie, who, as President of the

* 59 and 60 Vict. 1896, c. 48. 
Board of Trade, was in charge of the Bill, had said: "He thought that enterprise would be very largely stopped if a local authority could wait until they saw that one of these railways was a success and then come forward and demand to purchase it. That was a most unreasonable request to make, and would greatly interfere with the making of these railways." *

The Act instructs the President of the Board of Trade to appoint three Light Railway Commissioners, who may issue Provisional Orders for the building of light railways. Those Orders, upon confirmation by the Board of Trade, shall have effect as if enacted by Parliament. The Light Railway Commissioners, or the Board of Trade, among other things, may embody in the Orders provisions fixing the maximum rates and charges for traffic, as well as provisions empowering any local authority to acquire the railway at the expiration of a stated period and upon stated terms.

At the close of 1903 , the Light Railway Commissioners had dealt with 244 applications for Administration of Provisional Orders for tramways on Act represses Ini- streets and roads. Those tramways tiative in building were to have a route mileage of $187 \mathrm{I}$ Tramways miles, and they were estimated to cost $\$ 89,522,000$. The Light Railway Commissioners

* Hansard's Parliamentary Debates, July 30, I896, p. II 29 and following. 
had issued Provisional Orders for 127 tramways with a route mileage of 592 miles, and an estimated cost of $\$ 28,769,000$. They had rejected 62 applications, covering a route mileage of $6 \mathrm{I}_{7}$ miles. The remaining applications had been withdrawn, because the promoters had become convinced that the Light Railway Commissioners would reject them.* This record of the rejection of 68 per cent of the street railway mileage for which charters had been asked under the Light Railway Act does not mean that the building and operation of street railways is a "noxious trade" which should be restricted to the utmost, in the public interest. It means simply that the British Government, which determines the policy of the Board of Trade and the spirit with which that bureaucratic body administers the laws of Great Britain, is subject to the political pressure exercised through the House of Commons by the Association of Municipal Corporations and the Association of Urban District Councils. The former of these associations embraces 294 municipal corporations out of a total of 352 corporations. Its objects are: "By complete organization more effectually to watch over and protect the interests, rights, and privileges of municipal corporations

* Light Railways Act, 1896 . Report of the Proceedings of the Board of Trade up to December 31, 1903, and Proceedings of the Light Railway Commissioners up to the same date. 
as they may be affected by public Bill Legislation, or by private Bill Legislation of general application to boroughs; and in other respects to take action in relation to any other subjects in which municipal corporations generally may be interested." The second association embraces 500 out of a total of 800 Urban District Councils. Its objects are: "To afford members and officers of Urban District Councils an opportunity of giving expression to their opinions, to take action in matters affecting their interests, to offer Parliament, the Local Government Board, and other bodies the collective experience of Urban District Councils, to take cognizance of Bills introduced into Parliament affecting Urban District Councils and the working of laws affecting them, and to promote such measures as may from time to time be deemed advisable." *

The Light Railway Commissioners will not entertain an application for an Order for a tramway situate entirely within the area of one local authority. They hold that such applications should be made under the Tramways Act, I870, or by Private Bill. $†$

The Light Railway Commissioners will not issue

* The Municipal Year Book, 1904; and The Municipal Journal, April 7 and July 7, 1905.

$\dagger$ Light Railways Act, 1896. Report of the Proceedings of the Board of Trade up to December $3 \mathrm{r}$, I901, etc. List II, No. I7; List IV, No. 8; List VI, Nos. I 5 and 39. 
a Provisional Order if a railway company opposes the Order on the ground of competition. 'They hold that in such cases the matter should be submitted to Parliament.* The Commissioners, in the second year of their existence, issued a Provisional Order for an electric tramway three miles long, to be built from Coatbridge to Airdrie. $\dagger$ These towns are joined together so far as buildings are concerned, so that the proposed tramway would have been an urban tramway in the strict sense of the word. Upon the objection of the railway companies concerned, the Board of Trade overruled the Light Railway Commissioners, and refused to confirm the Provisional Order.

The Light Railway Commissioners will not issue a Provisional Order if all of the local authorities along the proposed tramway oppose the issue. $\S$ In such a case they will not even inquire into the merits of the proposed tramway. They have issued to several local authorities conjointly an Order which they had previously withheld from private promoters.\| They have also withheld an Order from one set of promoters, and subsequently they have issued practically the same Order to another set of promoters who had secured the indorse-

* List V, Nos. 27 and 49; List VI, No. 40; and List X, No. I8.

$\dagger$ List III, No. 3 .

$\ddagger$ Garcke: Manual of Electrical Undertakings, I899-1900, p. 469.

$\$$ List IV, Nos. 15 and 35 ; 19, List V, No. 45 ; List VI, No. 3 . List VII, Nos. 20 and 32 , and List VIII, No. I I.

11 List V, No. 45, and List VIII, No. 24; and List VII, No. 18. 
ment of the local authorities by means of a private bargain.*

The Corporation of Hastings indorsed the Electric Company's application for an order for Hastings, Bexhill, and District. But since the vote of the Corporation had not been unanimous, and there was strong opposition on the part of the residents and ratepayers of Hastings, the Commissioners "decided not to impose on the town a scheme not generally acceptable." $\dagger$

When the local authorities are divided on the question whether a Provisional Order should be granted, the Commissioners ask the promoters to prove that there is a public need or a general public desire for the proposed tramway. The promoters of the Finchley, Heaton, and District Tramway were unable to furnish such proof, though the three towns, which are suburbs of London, have populations of, respectively, 24,000, 22,000, and 82,000 , and are situated in a territory which has, on the average, one mile of street railway track for every 17,500 inhabitants. $\ddagger$

Edinburgh has 317,000 inhabitants, of whom I 7,400 in I90 I lived in the condition of 3 to Io persons in one room, while another 57,200 lived in the condition of 5 to I 2 persons in two rooms. Edinburgh has a municipal street railway route

* List VI, No. 3, and List VIII, No. 2.

$\dagger$ List III, No. I I. $\ddagger$ List III, No. 8. 
mileage of 23.5 miles, and a track mileage of 43 miles. But the Light Railways Commissioners rejected an application for an Order for 6.5 miles of tramway in Edinburgh and District, on the ground that "a sufficient case had not been made out as to the need for this line in the public interest." *

Glasgow with its suburbs has upwards of one million inhabitants, and less than I40 miles of street railway track. Glasgow proper has 760,000 inhabitants, of whom, in I90I, no less than 9I,200 were living in the condition of 3 to I 2 persons in one room, while another 194,300 were living in the condition of 5 to 12 persons in two rooms. In May, I898, the British Electric Traction Co., Ltd., applied for an Order for II.25 miles of electric tramway to connect Glasgow with the suburbs of Paisley, Renfrew, and Johnstone. "At the inquiry the promoters withdrew the portion giving access to Glasgow, and the Corporation of Paisley assumed an attitude of hostility to the scheme. The Commissioners were unable to approve it under the circumstances." $\dagger$

The British Electric Traction Co., Ltd., applied for an Order for a tramway, ro miles in length, in Morley District. The Company desired access to Bradford, but since the Bradford municipal tramways are built on a gauge of 4 feet, the British

$$
\text { * List I, No. } 27 . \quad \dagger \text { List IV, No. } 35 \text {. }
$$


Electric Co., whose tramways have a gauge of $4^{\prime} 8^{\prime \prime}$, could not apply for running powers over the municipal tramway. The Light Railway Commissioners refused to allow the company to build its own line into Bradford, and decided that the company and the municipality should join tracks at a point about 5 furlongs outside of Bradford, "that being the least inconvenient point for a break of gauge."* Under similar conditions the Light Railway Commissioners refused to give the Spen Valley Tramway, I2 miles in length, entrance to Bradford. In this case the Commissioners decided that the break of gauge should be at a point 1.25 miles outside of Bradford. $\dagger$ Bradford has 280,000 inhabitants, and 68 miles of street railway track. In November, I897, the British Electric Traction Co. applied for an Order authorizing it to build 13.25 miles of street railway in Bournemouth, Poole, and Christchurch, which have populations of respectively, 60,000, I9,000, and 4000. The application was rejected upon the protest of the Corporation of Bournemouth that its streets were too narrow to admit of the operation of street railways. In May, I898, the company applied for an Order for 7 miles of street railway in Poole, Christchurch, and Branxsome. The Light Railway Commissioners granted a Provisional Order for 5.5 miles, but the Board of Trade dis-

$$
\text { * List VII, No. } 3 \text { o. † List VII, No. } 34 \text {. }
$$


allowed I.75 miles thereof. In 1900, the Corporation of Bournemouth obtained a charter under the Tramways Act, I870, for the building of 12.25 miles of street railway in the very streets, which, in 1897 , it had said were too narrow to admit of the operation of street railways.*

The Light Railway Commissioners granted the Dewsbury, Batley, and Bristol Tramway Co., an established street railway, a Provisional Order to build extensions in Batley, which has a population of 30,000. The Corporation of Batley up to the time in question had neither built nor acquired tramways. But before the Board of Trade had confirmed the Order issued by the Light Railway Commissioners, the Corporation of Batley applied for permission to build a tramway in one or two miles of street covered by the Provisional Order granted to the Dewsbury, Batley, and Bristol Co. By way of compromise, the Board of Trade gave the company authority to build one track of the proposed double track railway, and the corporation power to build the other one. $\dagger$

Application was made for an Order for 5.5 miles of tramway, to connect Bradford and Leeds. The Commissioners issued an Order for 1.5 miles, the distance between the boundary of Leeds and that of Bradford. They denied entrance to Bradford

* Traction and Transmission, September, I903; and List III, Nos. 2 and 6 , and List IV, Nos. 6 and 24.

$\dagger$ Traction and Transmission, September, I903. 
and Leeds. Leeds has 437,000 inhabitants, and 78 miles of street railway track, owned by the city.*

In November, I898, Messrs. Greenwood and Batley, Ltd., applied for an Order for 6.25 miles of electric tramway in Nelson, Colne, and Trawden, Lancashire. None of the towns in question had any tramways, though Nelson and Colne had respectively 33,000 and 23,000 inhabitants. Thereupon the Borough of Nelson concluded that it would be a good speculation to execute that part of Messrs. Greenwood and Batley's scheme that lay within the borough of Nelson, I.25 miles, and thus to intercept a goodly share of the profit on any business that Messrs. Greenwood and Batley might build up between Nelson on the one hand, and Colne and Trawden on the other hand. The Light Railway Commissioners thereupon issued to Messrs. Greenwood and Batley an Order for their scheme, "with the exception of the portion in the borough of Nelson, which was granted to that Corporation." $\dagger$

It will be remembered that the Light Railways Act was enacted for a period of five years, which period was to expire on December 3I, I90I. In February, Igor, $\ddagger$ the Municipal Journal, the organ of the believers in the policy of municipal ownership, wrote as follows: "An attempt is to be made,

\footnotetext{
* List III, No. 3 . $\quad \dagger$ List V, Nos. 30 and $3 \mathrm{r}$. 
we learn, to give that legislative anomaly, the Light Railways Act, a permanent place on the Statute Book. . . . The Government is stated to be 'satisfied with the experiment.' They are not the only folk who have derived a measure of satisfaction from the Act. There are the astute tramway promoters, who have found the measure a very effective means of evading the restrictions of the Tramways Act, I870, and of freeing themselves of the burden of the purchase clauses. The Act has been employed for means never contemplated by its framers, and municipal authorities would be well advised if they would bring pressure upon the Government, either to secure the abandonment of the Act, or at least its amendment. Even the Permanent Secretary of the Board of Trade (Sir Courtenay Boyle) has had to confess that he is unable to differentiate between a light railway and a tramway. Perhaps Mr. Gerald Balfour (President of the Board of Trade), after he has had a chat with Sir Courtenay Boyle on the matter, will not be so keen about the reintroduction of the Act."

Notwithstanding this warning, Mr. Gerald Balfour, President of the Board of Trade, in April, I90I, brought in a Bill to amend and to continue Power of the for five years the Light Railways Municipal Cor- Act. In August, however, Mr. Balporations four withdrew the Bill, "simply and solely because it would have given rise to a 
large amount of discussion." * Mr. Balfour's statement was the parliamentary way of saying that the British Government was afraid to antagonize the Association of Municipal Corporations. The opposition to the renewal of the Act was determined and was based upon dissatisfaction with the purchase clauses which the Light Railway Commissioners had embodied in the Orders which they had granted for tramways. Since I90 I the Act of I 896 has been renewed each year for a period of one year.

With only three exceptions, the Orders granted for tramways down to December 3I, I90I, authorized the local authorities to purchase the tramways after a stated number of years on the basis of "fair market value as a going concern, but without any allowance for .compulsory purchase." The most common arrangement was 25 to 30 years; and in two cases it was respectively 40 years and 42 years.

In the case of the Hartlepool Electric Tramways Co., Ltd., the Borough of West Hartlepool had succeeded in getting power to purchase at the expiration of fourteen years, on the basis of the Tramways Act, 1870 ; and in the case of the West Hartlepool Light Railway Co., the Borough had obtained the right to purchase on the expiration of twentyone years, on the basis of the Tramways Act, I870.

* Hansard's Parliamentary Debates, April I, I901, p. 379, and August I4, p. 856 . 
In the case of the Bath and District Light Railway, the local authorities obtained power to purchase at the expiration of thirty-two years, on the basis of the Tramways Act, I87o. In this case the company undertook to effect street widenings that would cost upward of $\$ 57,000$. It obtained a charter for a route mileage of 13.5 miles.

One of the first Orders issued after the continuation of the Light Railways Act, in rgor, was that of the Donelly and District Tramway Co. It authorized compulsory purchase at the expiration of seven years, or at the end of each subsequent period of seven years. The price to be paid was an amount equal to the total capital expenditure properly incurred for the purposes of the tramway, provided that if purchase should be effected before the expiration of twenty-cight years, there should be added a bonus sufficient to raise the average dividend for the period of operation by the company to 6 per cent a year.

Early in 1902 the British Institution of Electrical Engineers appointed a committee of twelve to report upon the legislative policy toward the elecScience and $\mathrm{In}$ - trical industries. The committee dustry no Match comprised, among others, Lord Kelfor Politics vin, in the field of electricity the first scientist of Great Britain, and perhaps of the world; Jno. Perry, F.R.S., a past President of the society; S. P. Thompson, F.R.S., and past 
President of the Physical Society, the Röntgen Society, and the Institution of Electrical Engineers; Sir Michael Foster, one of the world's foremost physiologists; and Major General Webber, retired Royal Engineers, founder and past President of the Institution of Electrical Engineers. The Committee met eleven times, took. evidence, and passed nine resolutions "setting forth that the electrical industry had suffered greatly from restrictive legislation, . . . from the veto exercised by the local authorities, . . . and from the regulations imposed by the Government departments." The Committee asked Lord Salisbury, the Prime Minister, to hear them, but they were referred to Mr. Gerald Balfour, President of the Board of Trade.

Mr. Swinburne, President of the Institution of Electrical Engineers, was the spokesman of the deputation, consisting of the entire committee. He said: "They had formed a committee to see of what assistance they could be in removing the restrictions on the electrical industry, and they came to the conclusion that they might act as an advisory committee to the Board of Trade in dealing with the Electric Lighting Acts, the Tramways Act, and the Light Railways Act which at present hampered industry. Electrical enterprises should be limited by economical considerations only, and not by local boundaries; and should not be interfered with by local authorities, who could veto any enterprise that touched their 
district. They did not oppose municipal trading, but they objected to the abuse of the powers possessed by the local authorities. They wanted to prevent the pure unreasoning obstruction by local authorities who got provisional orders (for electric lighting) merely to prevent other people from coming into the district. They considered the compulsory purchase as an incubus on the industry; and further, the expense of Parliamentary procedure arrested the progress of the electrical as well as other engineering industries. The staff of the Board of Trade which dealt with the regulation of the supply of electricity ought to be strengthened, and nothing less than the Royal Commission was required to deal with the whole question of electrical legislation."

Mr. Balfour, President of the Board of Trade, replied: "He fully recognized the importance of the subject, and to a large extent sympathized with the deputation. He was afraid that it was undeniable that the electrical industry in this country was behind America and Germany, and perhaps some other of the continental countries. He did not contend that legislation applicable to the electrical industry was not susceptible of considerable amendment, or that the regulations were not restrictive in some instances, or that the local authorities had not abused the powers conferred upon them by Parliament, but it did not account fully for the backwardness of this country as compared with other countries. This 
must be remembered, that America was a new country very sparsely populated, with comparatively few established interests to contend with, whereas this was an old country with a very dense population, with a large number of strongly established interests, which produced a very strongly developed conservatism. It was these fundamental conditions rather than any legal enactments which retarded the electrical industry in Great Britain as compared with other countries. It appeared that the really important question was not so much that of any impediments thrown directly by the Legislature in the way of the development of the electrical industry as the power which the Legislature had given the local authorities to veto schemes. With respect to this matter they had to consider two branches of the subject, - namely, the electric supply and electric traction. In the case of tramways, so far as these matters were still determined by the provisions of the Act of I870, the local authority had an absolute veto upon measures proposed to be promoted by means of Private Bills. To some extent the evils following from that condition of things had been remedied by the adoption in many cases of the light railway procedure even where a scheme was in the proper sense of the term a tramway. But it was true that the Light Railway Commissioners and the Board of Trade had considered themselves more or less bound by the regulations laid down in the 
Tramways Act and the Standing Orders of the House of Commons. He did not think they had gone the length of giving the local authorities absolute veto, but no doubt they were influenced by those legal provisions. With respect to traction, the matter had been investigated recently by a Departmental Committee, on which both the promoters and the local authorities were represented. A Bill had been drafted which would go very far to meet all the reasonable objections that had been urged against the present powers of local authorities. But they should not conceal from themselves that the local authorities represented a very great power, and they quite saw that it was strongly to their interest to possess; if not an absolute veto, at all events a locus standi, which would enable them to make their views powerfully felt. Only the other day an attempt was about to be made to alter this Standing Order in the House of Commons, but it was abandoned because of this powerful opposition. That illustrated the difficulty of dealing with this question so long as local authorities took so strong a view as to the power which ought to be reserved to them in connection with this enterprise. In spite of that he had hopes that the compromise which had been arrived at by the Departmental Committee, and which had been embodied in a Bill, would be fairly satisfactory to both parties. As regards the electric supply, the case was somewhat different. The 
House of Commons Committee of 1898 on Electric Supply had made a series of recommendations; but legislation would be required to enable the Board of Trade to adopt those recommendations. The Board of Trade had also got a Bill ready to give effect to those recommendations; but he was afraid that he should not be able to give effect to either of those Bills this session; but they would do so at the earliest moment. The Board of Trade was as anxious as the deputation to secure that public interests should be properly served by the development of the electric industry. With regard to the appointment of a Royal Commission, he could not pledge himself, but he must consult his colleagues in the cabinet." *

It is not necessary to draw attention to the fact that the admissions made by Mr. Balfour in the latter part of his speech as to the powerful opposition of the municipalities, actuated by greed or gain, to the limitation of the local veto, are quite inconsistent with the statement made in the first part of the speech to the effect that the backwardness of Great Britain was due to the conservatism produced by established interests. One can scarcely dignify municipal greed to the extent of calling it a vested interest. Nor will any one seriously contend that the owners of private carriages, the proprietors of

* The Times, June 19, 1902; Engineering, June 20, 1902; and Traction and Transmission, October, 1904. 
the fashionable retail shops, the proprietors of omnibuses and cabs, and the owners of fine residences, who alone can be said to represent vested interests in this connection, would have been able to paralyze in succession the development of the horse tramway, the electric light, the electric tramway, the telephone, and the electricity-in-bulk power plant. The advocates of municipal trading in franchises, who developed the doctrine that the profits made by public service companies that use the streets belong to the public, and the politicians who took up that doctrine for the purpose of magnifying their office alone are responsible for the backwardness of Great Britain in every branch of the electrical industries but one - the ocean cable industry, which uses the bottom of the high seas, and has not yet been regulated by Parliament.

At the close of June, 1905, the British Government had not yet summoned courage to ask Parliament to remove the restrictions which for thirty-five years have paralyzed the development of the street railway industry by private initiative. 


\section{CHAPTER IV}

THE UNITED KINGDOM'S LACK OF STREET RAILWAYS

THE following table shows that in 1902, the year in which the Federal Government took a census of the street railways, 4I per cent of the towns in the

\begin{tabular}{|c|c|c|c|c|}
\hline \multirow[b]{2}{*}{$\begin{array}{l}\text { StREet RaILWAy Facilities of } \\
\text { Cities of Various Sizes }\end{array}$} & \multicolumn{2}{|c|}{ UNITED KINGDOM } & \multicolumn{2}{|c|}{ United States } \\
\hline & Number & $\begin{array}{l}\text { Proportion } \\
\text { thereof sup- } \\
\text { plied with } \\
\text { street rail- } \\
\text { ways in rgo3 }\end{array}$ & Number & $\begin{array}{l}\text { Proportion } \\
\text { thereof sup- } \\
\text { plied with } \\
\text { street rail- } \\
\text { ways in } 1902\end{array}$ \\
\hline Cities with a population of: & & $\%$ & & $\%$ \\
\hline 5,000 and less than 6,000 & 95 & I I & 147 & 41 \\
\hline $6, \infty 00$ and less than 7,000 & 75 & 13 & 98 & 52 \\
\hline $7, \infty 00$ and less than 8,000 & 60 & 13 & 75 & 61 \\
\hline 8,000 and less than 9,000 & 43 & 9 & 45 & 71 \\
\hline 9,000 and less than 10,000 & 44 & I6 & 50 & 76 \\
\hline $10, \infty \infty$ and less than 12,000 & 84 & I 7 & 62 & 84 \\
\hline I 2,000 and less than 15,000 & $9 \mathrm{I}$ & $3 \mathbf{I}$ & 75 & 95 \\
\hline $15, \infty 00$ and less than 20,000 & 75 & 30 & 72 & 100 \\
\hline 20,000 and less than 30,000 & 82 & 50 & 78 & 100 \\
\hline $30, \infty 00$ and less than 40,000 & 47 & 64 & 43 & 100 \\
\hline 40,000 and less than 50,000 & 30 & 80 & I 3 & 100 \\
\hline 50,000 and less than 60,000 & 13 & 100 & I 7 & 100 \\
\hline $60, \infty 00$ and less than 70,000 & 13 & 92 & 7 & 100 \\
\hline
\end{tabular}

United States having a population of 5000 and less than 6000 were supplied with street railways; that, 
with the increase of towns, the percentage supplied with street railways increased regularly and rapidly; and that all towns and cities of 15,000 and more inhabitants had street railways. In the United Kingdom, on the other hand, in the year 1903 , only 9 to I 3 per cent of the towns of 5000 and less than 9000 inhabitants had street railways; for towns of i 2,000 and less than 20,000 the percentage in question was 30 ; and not until cities of 70,000 and more inhabitants were reached could one count on finding in every instance a street railway.

Turning from the question of the size of the towns and cities to which the street railways have penetrated in the two countries under comparison, to the question of the respective extents of the street railways in those towns and cities which have street railways, one finds even a greater disproportion between conditions in the United States and the United Kingdom. The subjoined table shows that in the United States, in the year 1902, in a total of 530 cities, groups of cities and towns, and groups of towns, there was: in 24.7 per cent of the cases more than one mile of street railway track for each rooo people; in 32 per cent of the cases one mile of street railway track for each 1000 to 1499 people; in 21.9 per cent of the cases one mile of track for each I 500 to 1999 people; and in 10.7 per cent of the cases, one mile of track for each 2000 to 2599 people. In the United Kingdom, on the other hand, there was, in I903, 
no case of one mile of track for each I 500 people or less. The most common ratio between street railway trackage and population was: one mile of track for each 5000 to 5999 people, and one mile for each 7000 to 7999 people, the next most common ratio was one mile of track for each 4000 to 4999 people, and each I3,000 to 19,999 people; the third most common ratio was one mile for each 3000 to 3999 people; and the fourth most common ratio was one mile for each II,000 to I I,999.

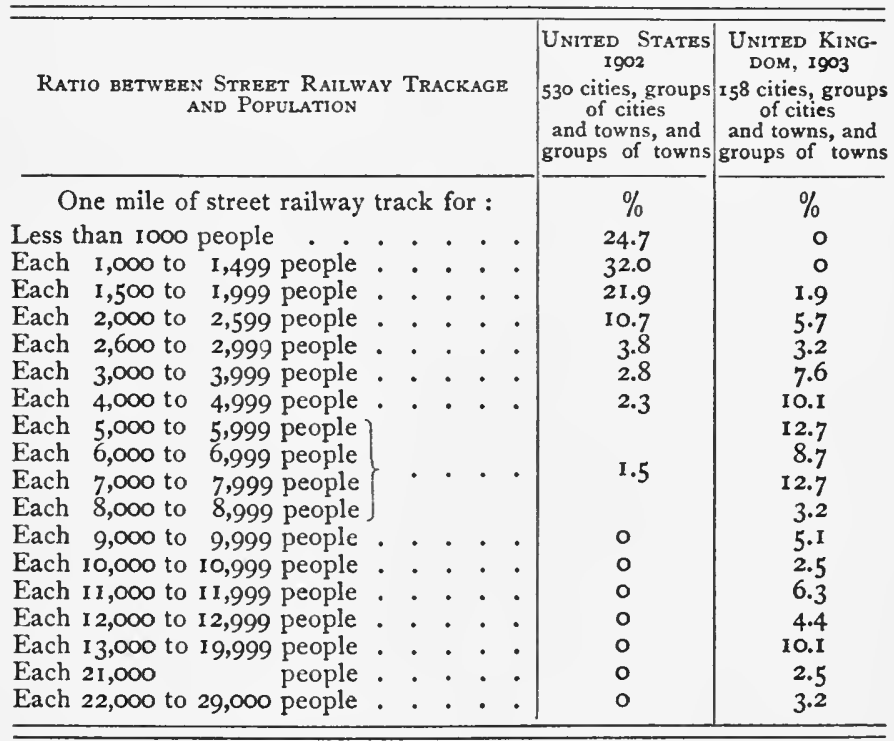

These figures, it is true, relate to the year 1903. On the other hand, there has been no material 
change in conditions since that year, as appears from the fact that the total street railway route mileage of the United Kingdom increased only from 1772 miles, in June, I903, to I 840 miles, in March, I904. The subjoined table elucidates in detail this subject of the ratio between street railway trackage and population.

In June, 1902, there were in the United States $16,65^{2}$ route-miles of street railway, and 22,589 track-miles of street railway. Not less than 14,000 track-miles thereof were located within urban limits. The United Kingdom has practically the same urban population as the United States;* therefore it should have about the same urban street railway track mileage, namely 14,000 miles.

In March, 1904, the total urban and interurban street railway route-mileage of the United Kingdom

\begin{tabular}{|c|c|c|c|c|}
\hline * URBan Population & NUMBER & $\begin{array}{l}\text { UNITED KINGDON } \\
\text { IgoI } \\
\text { Aggregate popu- } \\
\text { lation }\end{array}$ & NUMBER & $\begin{array}{l}\text { UntTed States } \\
\text { Igoo } \\
\begin{array}{c}\text { Aggregate popu- } \\
\text { lation }\end{array}\end{array}$ \\
\hline \multicolumn{5}{|l|}{ Cities with a population of: } \\
\hline $\begin{array}{l}250,000 \text { and upward } \dot{1} \text {. } \\
100,000 \text { and less than }\end{array}$ & 13 & $9,691,000$ & I5 & $10,936,000$ \\
\hline${ }_{50,000}^{250,000}$ and less than & 26 & $3,833,000$ & 23 & $3,272,000$ \\
\hline 100,000 and less than & 47 & $3,371,000$ & 40 & $2,709,000$ \\
\hline${ }_{10, \infty 00}^{50,000}$ and less than & I 59 & $4,968,000$ & 135 & $3,971,000$ \\
\hline 20,000 . . . . . . & 250 & 3,4 I2,000 & 209 & $3,251, \infty 00$ \\
\hline TOTALS & 495 & $25,275,000$ & 422 & 24, I 39,000 \\
\hline
\end{tabular}


was I 840 miles, ${ }^{*}$ while the track-mileage did not exceed 3200 miles. From these figures it follows that the people living in the cities and towns of the United Kingdom have at their service less than onequarter of the street railway facilities that the people have who live in the cities and towns of the United States. $\dagger$

In an earlier chapter it was shown that the city population of the United Kingdom in I880 had less than one-fifth of the street railway facilities that the city population of the United States had; and that in 1890 it had considerably less than one-third of the facilities. It has just appeared that in 1904 it had less than one-fourth of the facilities. In other words, the paralysis of private enterprise under the application of the doctrine that the profits to be made out of the so-called public service industries that use the public streets belong to the general public and not to "private speculators" has been complete and

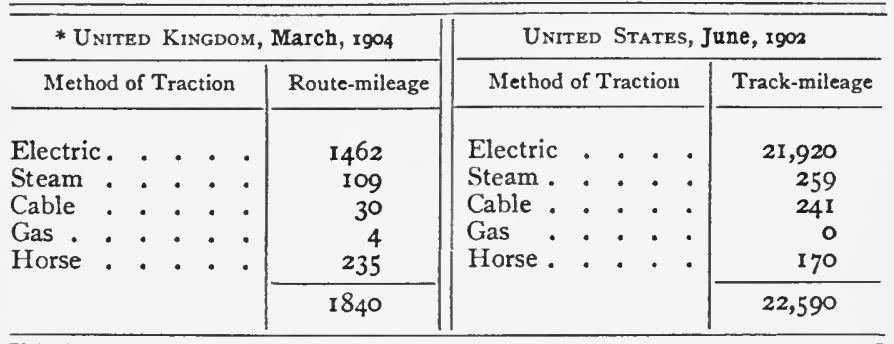

† The slowness of the growth of transportation facilities is indicated by the fact that data received since the text was put in type show that in January, 1906, the route mileage was $197^{\circ}$. 
92 MUNICIPAL OWNERSHIP IN GREAT BRITAIN

permanent. Equally complete and permanent has been the failure of the municipalities to fill the void which they had created by paralyzing private enterprise. 


\section{CHAPTER V}

\section{GLASGOW}

IN I870 a Private Act of Parliament gave a company power to build and operate street railways in Glasgow. In that same year the city of Glasgow acquired the powers of the company, and accordingly it has always been the sole builder of street railways in Glasgow. In 1872 the city leased the tramways for twenty-one years to the Glasgow Tramway and Omnibus Co.

In 1887 that company asked for an extension of its lease, offering to adopt "motor (mechanical) traction of some kind" and to increase its rolling stock.* But the city failed to offer terms that the company could accept. The company had leased only the tracks and had been obliged to provide the barns, horses, and rolling-stock, the city being under no obligation whatever to purchase any of the aforesaid equipment upon the expiry of the company's lease. When it became certain, in 1887 , that the city would not renew the lease in 1893 , and remained very uncertain whether the city would purchase the company's equipment, the company was compelled

* Report from the Joint Select Committee on Municipal Trading, I900, q. $344 \mathrm{I}, 3484$, and 3488 . 


\section{MUNICIPAL OWNERSHIP IN GREAT BRITAIN}

to practice the utmost economy in the maintenance of that equipment - that is, it was obliged to withdraw as much of its capital as possible by letting the equipment run down.

When the Glasgow Tramway and Omnibus Co. was organized in 1873 , it not only took a lease of the tramways, but also bought up, at a cost of $\$ 750,000$, the business of all omnibus proprietors in the city and suburbs, and so acquired a monopoly. The company's articles of association, which were approved by the city, provided for the carrying on, at the termination of the tramway lease, of the business of omnibus proprietors. But when the city terminated the tramway lease, it refused to buy any of the company's equipment, unless the company should agree not to compete with the city tramways. The company declined to make any such agreement, and the city refused to purchase any of the company's barns, horses, or cars.*

At a total cost of $\$ \mathrm{I}, 955,000$ the city now built new barns and horse cars, and purchased between 3500 and 4000 horses. The city at this time, I893, was City assumes convinced that some form of mechaniOperation of cal haulage or propulsion would be the Tramways in 1893, using Horse haulage or propulsion of the near Power future, but it could not make up its mind whether the motive force would be compressed air, oil, cable, or electricity. As for electric trac* Traction and Transmission, 1902, p. 159. 
tion, the city was convinced that the overhead trolley was doomed, and it was entirely unwilling to consider the proposal to use the overhead trolley temporarily.

In 1898 , when the horse car had all but disappeared in the United States, the city of Glasgow, by way of experiment, equipped electrically 2.5 miles of street railway. In January, I899, it resolved to equip its whole system electrically, and in April, I9o I, electric traction was inaugurated. To repeat, while electric traction still was an experiment, the city refused to offer the lessee company terms that would justify the company in trying and promoting the experiment; nor did the city itself contribute anything to the establishment of the new mode of traction. It merely copied, at a safe distance of ten or a dozen years, the results attained by private enterprises in the United States.

The city of Glasgow always has been one of the most determined opponents of any proposal to modify the law limiting the franchises of street railway Glasgow opposes companies to twenty-one years. Yet Perpetual Fran- in July, I90I, Glasgow had a clean chises - except record of refusal to build tramways for itself into any suburb of Glasgow unless that suburb consented that Glasgow should have a perpetual charter for the street railway built.* Such

* Hansard's Parliamentary Debates, July 23, r9or, p. I250, Lord Balfour of Burleigh, Secretary for Scotland, and the Earl of Morley, 
perpetual charters the city obtained in 1870,1875 , I879, I885, I893, I899, and I901.

In 1889 , the close of the horse railway era in the United States, the city of Glasgow had built 6I miles of street railway tracks in 31 miles of street. In that same year, Boston, with its suburbs, containing about io per cent fewer people than Glasgow, had 23I miles of street railway track. In May, I904, Glasgow and its suburbs had 146 miles of street railway track, or one mile for each 6700 people; at that same time Boston and its suburbs had one mile of track for each 2300 people, or almost three times the facilities of Glasgow.

It is not necessary, however, to go to the United States for comparisons of this kind. Dublin, Ireland, is rather a sleepy town, with a residential rather than an industrial population, numbering 353,000 people, suburbs included. In December, 1904, Dublin had one mile of street railway track for each 3500 people. In 1894, Mr. W. M. Murphy, Chairman of the Dublin United Tramways, who, since I 868, has been a builder of tramways in all parts of the United Kingdom, as well as on the Continent, went to the United States to investigate electric traction, "saw that the thing was not only practicable but profitable, that it had come to stay and was a perfect success, so far as one could see,

Lord Chairman of Committees; and Report from the Joint Select Committee on Municipal Trading, 1900, q. 3959 and 2825. 
in the United States." The deadly Tramways Act, I870, does not extend to Ireland, and its provisions had not been incorporated in the earlier charters granted to the Dublin United Tramways, though they had been incorporated in the later ones. In I894, Mr. Murphy proposed to the city of Dublin to equip his street railway for electric traction if the city would give him a blanket franchise for fortytwo years from I894; the city to have the right to purchase at the end of that period at cost of replacement plus 33 per cent for good-will allowance. In addition, Mr. Murphy offered to make certain annual way-leave payments, which now amount to $\$ 70,000$ a year for 100 miles of track. As soon as the adherents of municipal ownership in England and Scotland heard of the proposal, they sent their agents to Dublin to work up a public sentiment against the adoption of the proposal, and thus prevented Mr. Murphy from getting the approval of the city before late in 1895 . In 1896 electric traction was begun in Dublin.*

It is well, whenever opportunity affords, to contrast the promises and protestations of the adherents Contrast between of municipal ownership with their Promises and achievements. In 1870, before the Achievements city of Glasgow had acquired the rights of the company that had obtained a street rail-

* Report from the Joint Select Committee on Municipal Trading, I9oo, q. 1436 to 1447,1497 , and 1516 . 
way franchise, the city of Glasgow sent Mr. A. Munro to represent it, as well as Edinburgh and Dundee, before the Parliamentary Committee on the Tramways Bill. Before that committee, Mr. Munro said: "In Glasgow we are very much limited in space; our population is far too dense for the area on which the city is built. We are now making arrangements for the purchase of large portions of ground beyond the municipal area, for the erection of houses for the poorer classes of citizens; if the tramways were in the hands of the corporation, they could be carried to such a distance as to bring the poorer people to their work at low fares, or they could stipulate with the contractor (lessee in the case of the tramways being leased) to run certain carriages, at certain hours of the day, at low rates." *

The census of Igor showed that Glasgow proper had a population of 760,000 ; and that there were in Glasgow proper 91,205 overcrowded persons living in the condition of 3 to 12 persons in a room, and I 94,284 overcrowded persons living in the condition of 5 to I 2 persons in 2 rooms. $\dagger$ The number of over648 .

* Report of the Committee on Tramways Bill, 187o, q. 602, 637, and

† Overcrowding in Glasgow in igoi

26,049 overcrowded persons living 3 to $I$ room. 25,276 overcrowded persons living 4 to 1 room. I 9,535 overcrowded persons living 5 to I room. II,100 overcrowded persons living 6 to 1 room. 5,642 overcrowded persons living 7 to 1 room. 2,336 overcrowded persons living 8 to I room. $\mathbf{1 , 2 6 7}$ overcrowded persons living 9 to $I 2$ to $I$ room. 
crowded persons living in one room had increased from 90,900 in I89I to 91,200 in I90I; and the number of overcrowded persons living in two rooms had increased from 187,000 in 1891 to 194,300 in Igor. In the meantime the total population had increased from 565,000 in I89 I to 760,000 in I90I.

Thus far the corporation of Glasgow has failed absolutely to use the electric street railway for the purpose of "suburbanizing" the population. It has used it only for the purpose of putting money into the city treasury and for the purpose of "magnifying the office" of the municipal politician.

Let us stop for a moment to consider what the "suburbanizing" of the population would mean for the health and happiness of the people of Glasgow. In I90 I the death-rate per rooo inhabitants of Glasgow was: II.2 for the dwellers in houses or tenements of 4 or more rooms; I3.7 for the dwellers in tenements of 3 rooms; $2 \mathrm{I} .3$ for the dwellers in

6,105 overcrowded persons living 5 to 2 rooms. 57,258 overcrowded persons living 6 to 2 rooms. 51,016 overcrowded persons living 7 to 2 rooms. 37,784 overcrowded persons living 8 to 2 rooms. 23,301 overcrowded persons living 9 to 2 rooms. I 1,720 overcrowded persons living Io to 2 rooms. 4,664 overcrowded persons living in to 2 rooms. 2,436 overcrowded persons living 12 to 2 rooms.

\begin{tabular}{c|c|c|c}
\hline Year & $\begin{array}{c}\text { Overcrowded ONE-ROOM } \\
\text { DWELLERS }\end{array}$ & $\begin{array}{c}\text { Overcrowded TWO-ROOM } \\
\text { DWELLERS }\end{array}$ & $\begin{array}{c}\text { Total } \\
\text { PopUlation }\end{array}$ \\
\hline 1871 & 115,300 & 145,500 & 477,000 \\
1891 & 90,900 & 187,000 & 565,000 \\
1901 & 91,200 & 194,300 & 760,000 \\
\hline
\end{tabular}


tenements of 2 rooms; and 32.7 for the dwellers in one-room tenements. The death-rates from respiratory diseases were, respectively: $2.7,3.6,6.4$, and ro.* If the reader be inclined to object that these figures are not conclusive, on the ground that crowding is only one of the evils of poverty, all of which make for an increased death-rate, let him consider the following figures. In the decade from 1837 to 1846 , the mortality from lung diseases in the four branches of the British Army ranged from 5.65 per 1000 in the cavalry of the line to II.9 per 1000 in the Foot Guards. The only decided difference between the various arms was the condition of overcrowding in the barracks. Again, in the seven years from 1864 to 1870 , the mortality from lung diseases in the cavalry of the line was I.4I only, while the mortality in the Foot Guards was only 2.30. The only decided difference in the conditions of these respective arms in the two periods from 1837 to $\mathrm{I} 846$ and $\mathrm{I} 864$ to $\mathrm{I} 870$ was the increased cubic space per man in the barracks. $\dagger$

While the city of Glasgow's policy of operating street railways primarily as a money-making machine has been little short of disastrous, so far as the well being of tens of thousands of citizens is concerned,

* A. K. Chalmers, Medical Officer of Health for the City of Glasgow: The Death-Rate in our Apartment Houses: An Enquiry based on the Census Returns of 1901 .

† J. F. J. Sykes: Public Health and Housing; being the Melroy Lectures delivered before the Royal College of Physicians, London, I90I. 
it has not been successful even from the view-point of public finance. In $1902-3$ the street railways yielded a gross revenue of $\$ 3,27 \mathrm{I}, 000$; out of that revenue they paid in taxes $\$ 9 I, \infty 00$, contributed to the "Common Good" \$1 25,000,* and paid in to the sinking fund for reduction of the capital debt the sum of $\$ 216,500$. That made a total payment "to the public benefit account" of $\$ 432,500$, or I3.I per cent of the gross earnings, or \$o.44 per head of population served by the Glasgow tramways. The Boston Elevated Railway Co., serving a population not quite so large as that of Glasgow and its suburbs, has earnings of about $\$ 12,000,000$ and pays "to the public benefit account," in cash and in services, upward of \$1,550,000 a year, or nearly I3 per cent of its gross earnings, or $\$ 1.67$ per head of population served. This comparison shows that the city of Glasgow could collect in taxes from an adequate system of street railways in private hands a much larger sum than it now obtains from the operation of an entirely inadequate system of municipal street railways. British as well as American capitalists would gladly give Glasgow a street railway system on the basis of one mile, or more, of track for each 2300 people, should the city offer them a sufficiently

* Report from the Joint Select Committee on Municipal Trading, Igoo, q. 2924. S. Chisholm, Lord Provost of Glasgow: "There is a payment to the common good of $£ 12,500$ (now $£ 25,000$ ), that is something in the shape of mileage; the tramway (Corporation of Glasgow) do not like to call it so, but it is practically just a mileage on the use of the street equivalent to what the old company used to pay to the Common Good." 
102 MUNICIPAL OWNERSHIP IN GREAT BRITAIN

liberal franchise. In making the foregoing comparison, the author does not express approval of the practice of taxing the Boston Elevated Railway Co., to the extent of 13 per cent of its gross earnings. On the contrary, he is of opinion that that taxation is excessive and curtails the facilities offered by the company to the public of Boston and its suburbs. 


\section{CHAPTER VI}

GLASGOW PROVES THAT GRADED FARES MEAN CONGESTION OF POPULATION

Glasgow Street Railway Fares

\begin{tabular}{|c|c|c|c|}
\hline \multirow[b]{2}{*}{$\begin{array}{c}\text { Fare } \\
\text { in Cents }\end{array}$} & \multirow{2}{*}{$\begin{array}{c}\text { UNDER Company's } \\
\text { MANAGEMENT } \\
\text { Distance, in Miles }\end{array}$} & \multicolumn{2}{|c|}{ UNDER MUNicipality's MaNagement } \\
\hline & & $\begin{array}{l}1894 \text { to June, r9o2 } \\
\text { Distance, in Miles }\end{array}$ & $\begin{array}{l}\text { Since June, Igoz } \\
\text { Distance, in Miles }\end{array}$ \\
\hline $\begin{array}{l}1 \\
2 \\
3 \\
4 \\
5 \\
6 \\
7 \\
8 \\
9\end{array}$ & $\begin{array}{c}\text { None } \\
1.12 \\
1.80 \\
2.20 \\
\text { None } \\
3.23 \\
\text { None } \\
\text { None } \\
\text { None }\end{array}$ & $\begin{array}{c}0.58 \\
1.75 \\
2.33 \\
3.47 \\
4.18 \\
5.34 \\
? \\
? \\
?\end{array}$ & $\begin{array}{r}0.5^{8} \\
2.32 \\
3.48 \\
4.64 \\
5.80 \\
6.89 \\
8.15 \\
9.09 \\
10.15\end{array}$ \\
\hline
\end{tabular}

THE foregoing table shows that under the company's management the lowest charge was. 2 cents, for I.I 2 miles; and that the municipality, on taking over the tramways in 1894 , divided each route into half-mile stages, and made the fare for the half-mile stage I cent. For three half-mile stages the fare was 2 cents, for six half-mile stages it was 4 cents, and for nine half-mile stages it was 6 cents. In June, I902, the municipality added one half-mile 
stage to the 2-cent fare, two stages to the 4-cent fare, and three stages to the 6-cent fare.

In August, 1903, in a report to the Tramways Committee of the Corporation of Glasgow, Mr. John Young,* General Manager of the Glasgow Tramways from 1894 to September, I904, analyzed the results of the system of graded fares. $t$ It appeared that 93 per cent of the passengers travelled less than 2.5 miles, and that only I.55 per cent of the passengers - 2,744,000 persons a year - travelled up-

* On September 30, 1904, Mr. Young resigned his position with the City of Glasgow in order to enter the service of Mr. Yerkes, Chairman of the Underground Electric Railways Company, of London, Limited, "as his right-hand man in the control of the tubes and tramways of his companies." Mr. Young was succeeded by Mr. James Dalrymple, who had served in the Tramways Department since 1894 . He had entered as an accountant, and for several years had been Mr. Young's chief assistant and deputy general manager.

†YEAR 1902-3

\begin{tabular}{|c|c|c|c|}
\hline \multirow{2}{*}{$\begin{array}{l}\text { FaRR, } \\
\text { IN CENTS }\end{array}$} & \multicolumn{2}{|c|}{ Passengers Carried } & \multirow{2}{*}{$\frac{\text { Traffic Receipts }}{\text { Per Cent }}$} \\
\hline & Number & Per Cent & \\
\hline \multirow{6}{*}{$\begin{array}{c}\text { I } \\
2 \\
3 \\
4 \\
5 \\
6 \\
\text { and upward }\end{array}$} & $56,788,87^{2}$ & 32.05 & I 8. II \\
\hline & $108,021,739 \ddagger$ & 60.97 & 68.91 \\
\hline & $9,624,799$ & $5 \cdot 43$ & 9.21 \\
\hline & $\begin{array}{r}2,098,181 \\
447,987\end{array}$ & $\begin{array}{l}1.19 \\
0.25\end{array}$ & $\begin{array}{l}2.68 \\
0.71\end{array}$ \\
\hline & 197,97 I & O.I I & $0.3^{8}$ \\
\hline & I 77, I 79,540 & 100.00 & 100.00 \\
\hline
\end{tabular}

$\ddagger$ Careful investigation showed that "almost one-half of the twocent passengers travelled little more than one mile, or about the distance of two one-cent stages." 
ward of 3.5 miles. The results amply confirmed the saying that the Glasgow tramways "churned the people up within the city limits" but did not enable them to escape beyond those limits.

Mr. Young also showed that the average receipts per passenger carried were 1.76 cents, while the average cost per passenger was 1.50 cents, leaving a margin of profit of 0.26 cent per passenger carried.

In the following December, Mr. Young made a supplementary report to the Sub-Committee of the Tramways Committee of the Corporation of Glasgow. Therein he said: "You are aware that I have always been in sympathy with, and have acted on, the view that the surplus revenue of the Department should be apportioned in the first place, to the benefit of those who use the cars. We are only, however, in our second year, exclusively of electric traction, and before taking any irretrievable step in the direction of further reducing our exceedingly low fares, those responsible for the efficiency and success of the tramway undertaking should carefully consider the following points which, in the future, are sure to have an important bearing on our revenue and expenditure: (I) an increased service on most of the existing routes is called for, and is being provided as quickly as possible; (2) additional cross routes in the city are being constructed, and you are being called upon to construct others; (3) for selfprotection, and in order to complete the Glasgow 
tramway zone, the principle of which has been established, we are even now promoting an 'Order' (i.e. asking the Board of Trade for an Order) principally for outside extensions; (4) we shall probably experience the recurrence of a period of depression and bad trade, during which our revenue is certain to be adversely affected. We have, fortunately, had a continuous run of good trade since we took over the tramways in I894, but we cannot expect this to continue always without a break. It is thus obvious that the narrow margin of profit we have to work upon, viz. 0.26 cent per passenger, can easily be made to disappear without further reducing fares. Besides, no one can foresee what the advance of science will bring about in the near future. We cannot afford to look upon obsolescence of plant as only a bogey in these times of abnormal progress. In this connection, it should not be lost sight of that our capital expenditure is at present over two millions sterling. It is true we are paying off our large debt by means of the Sinking Fund; but we cannot be sure that long before the Sinking Fund period of thirty-one years has expired much of the present plant, and even our system of traction, will not have become obsolete. Until our system is more complete and consolidated, I recommend the continuation of the policy which the Committee have carried out since the formation of the Department in 1894, and in which our safety lies, viz. that any 
available surplus revenue should be devoted to the reduction of our borrowed capital."

This report compels the conclusion that $\mathrm{Mr}$ : Young would have held without qualification that the margin of profit of 0.26 cent per passenger carried was too small to permit the rapid extension of the Glasgow street railways from the existing proportion of one mile of track for 6700 people, to one mile of track for 2300 people, the proportion existing in Boston. On the other hand, it is obvious that something like that proportion must be obtained before the Glasgow street railways can aid materially in "suburbanizing" the present overcrowded population. Further proof of the soundness of these deductions from Mr. Young's reports is found in the fact that Mr. Young's successor and Mayor Dunne's "expert," Mr. Dalrymple, stated in Chicago, in Cleveland, and elsewhere, that the American street railway systems could not afford to reduce the fivecent fare under the retention of the system of practically universal transfers.

It was therefore a disastrous mistake for the city of Glasgow to inaugurate the system of municipal operation of the tramways by extending the system Decentralization of graded fares. The city should prevented by have adopted the American practice Graded Fares of a uniform fare. That uniform fare should have been one adapted to the pocketbooks of the merchants, professional men, clerks, 
and better-paid mechanics, the classes that will take advantage of improved transportation facilities and move into the suburbs. The great decentralization of population effected in the American cities under the régime of the trolley cars was effected in that way. The merchants, professional classes, clerks, and betterpaid mechanics moved into the suburbs, and the houses formerly occupied by them became available for the less well-paid mechanics and the day-laboring classes, and afforded them greatly improved housing.

From Park Street station, Boston, a passenger may ride 9.53 miles to Arlington Heights; 9.83 miles to Charles River Bridge; 8 miles to Waverly; 7.9 miles to Melrose line; 7.36 miles to Milton; 7.3 miles to Neponset; 6.32 miles to Woodlawn; and 6.04 miles to Lake Street. The uniform fare for any of these journeys, or for any two of them in combination, through free transfers, is 5 cents. The citizen of Glasgow and its suburbs has no such facilities; and if he had them, he could not use them. Under the system of graded fares in force the charges for these journeys would be 6,7 , and 8 cents, and therefore prohibitive. For it must be remembered that a given sum of money is worth fully 30 per cent more to the people of Glasgow than to the people of the United States, because it is much more difficult to earn. To illustrate: the municipal tramways pay the motormen and conductors $\$ 0.96$ a day for the first six months of service, and they raise that sum 
until, after three years' service, it reaches $\$ 1.20$ per day of to hours. The Boston street railways pay their motormen and conductors $\$ 2.25$ per day of 9.5 hours of platform work. It is safe to say that 6 cents in Glasgow are equivalent to 8 cents in the United States; and the experience of the United States shows that it would be impossible to induce even the better-paid half of the community to move freely in the suburbs on the basis of a charge of 8 cents, or, for that matter, any sum above 5 cents.

Three cents in Glasgow would correspond to 5 cents in the United States, considering the respective earning powers of the people of Glasgow and the people of the United States. A uniform fare of 3 cents in Glasgow would afford the Tramway Department a margin of profit that would justify the rapid extension of the net that the present congestion of the population demands.

The foregoing discussion has shown that in Glasgow the margin of profit per passenger carried is only 0.26 cent under the system of graded fares, and that that margin does not justify any rapid extension of the net ahead of population for the purpose of inducing the better-paid half of the community to move into the suburbs, or, rather, to create the suburbs. It now remains to add that the Glasgow Tramway Department is not even sure of its ability to retain that slender margin of profit. The temptation is irresistible to well-meaning but ill-informed persons 
and to the demagogues to demand that the I-cent stage be enlarged, on the ground that, if the city can carry people 2.32 miles for 2 cents, it certainly can carry them more than $0.5^{8}$ mile for I cent. Both of the aforementioned reports of Mr. Young were called out by precisely that argument. Some persons had demanded that the penny stage be doubled, others that it be lengthened to three-quarters of a mile, or a mile. These demands led Mr. Young to say: "It is very easy for persons, whose good faith is unquestionable, but who have no responsibility in the matter, to get up an agitation, calling for concessions in the tramway service. It must be borne in mind, however, and I say it with all respect - that these people have not the means of knowing all the bearings of the case. It certainly cannot be expected that they have sufficient knowledge to advise on a question seriously affecting the financial position and outlook of a large department, or even to give a deliverance as to what is most serviceable to the community as a whole. I am afraid if the large commercial departments of the Corporation, like the Water, the Gas, the Electricity, or the Tramways, are to be influenced by movements of this kind, the results may be disastrous."

The proposal to lengthen the I-cent stage of course always is made on behalf of the wage-earning classes. But Mr. Young points out that it is a fallacy to suppose that the wage-earning class form 
the bulk of the I-cent passengers. On the conWage Earnersget trary, only $\mathrm{I}$ in 5 of the "workmen" Little Benefit using the early morning cars is a I-cent passenger. The percentage at different fares is as follows: I cent, 20.4 per cent ; 2 cents, 72.3 per cent ; 3 cents, 6.2 per cent ; 4 cents, 0.94 per cent ; 5 cents, 0.6 per cent. The $\mathrm{I}$-cent passengers are principally those whose duties necessitate their frequent moving about the city. This is the class who would to the largest extent get, and take, the advantage of the I-cent fare. In other words, the I-cent fare is a cheap luxury to the merchants, the professional men, and the wives and daughters of those classes when engaged in shopping expeditions. It is cheap luxury that is of no particular importance to them, but is of serious consequence to the clerk and mechanic who would like to move his family into the suburbs, but finds the opportunity greatly restricted by reason of the I-cent fare. Street railways built out into and beyond the outskirts of the city, for the purpose of building up suburbs, take time to develop. They are commonly called "feeders," but for the first years they are "suckers," that is, losing ventures. No street railway manager can afford to build them on any considerable scale unless he has a considerable margin of profit on the carriage of the passenger who wishes to indulge the luxury of saving the walking of a few blocks.

Glasgow is not the only city in which the expert 


\section{MUNICIPAL OWNERSHIP IN GREAT BRITAIN}

tramway manager has to fight hard against unwise proposals to lower passenger fares. For some years past Mr. C. R. Bellamy, the General Manager of the Municipal Tramways of Liverpool, has been hard pressed by persons demanding the introduction of the I-cent fares. At the annual meeting of the Municipal Tramways Association, held in July, 1905, Mr. Bellamy expressed himself as follows: "He submitted the proposition that the unit fare and stage should be fixed so as to secure that the passengers travelling to the outskirts of a large town, a distance of 4 or 5 miles, could be carried for a fare not excceding 4 cents, and that this could not be done with a cent-a-mile unit. . . . Municipalities had problems to consider in conjunction with their tramways apart from what might be termed 'the equitable adjustment of stages.' As an example, take the illustration - perhaps the most important from the general point of view of - a municipality - the overcrowding in the central area of large towns, which had resulted largely in consequence of a dearth of travelling facilities. The question of how far a workman resided from his work was of no moment. The important considerations were: How many minutes need be occupied in covering the distance and the cost in doing it? If they accepted the principle that a wider distribution of the inhabitants in large towns was desirable, it was important that long-distance passen- 
gers should be especially considered, and that they should be carried to the outskirts where land was plentiful as cheaply as possible." *

In the year 1902 not less than 89 per cent of the passengers carried by the Liverpool tramways travelled not to exceed 2.3 miles, and only 3844 passengers travelled 6 miles. $\dagger$ In December, I904, Liverpool and its suburbs had a population of 763,000 , and only 103 miles of street railway track, or one mile for each 7400 inhabitants. In I901, there were living in Liverpool proper, in the overcrowded condition of more than two persons in one room, 54,390 persons, or 7.94 per cent of the population. $\ddagger$

Before leaving this subject, mention should be made of a resolution recently passed by the Corporation of Glasgow, and the comments thereon made by The Municipal Journal, $\S$ the organ of the

* The Municipal Journal (London), July I I, I902. See also issues of February 27, 1903, and February 3, r905.

† Liverpool Municipal Tramways, Year Ending Dec. 31, 1902

\begin{tabular}{c|c|c|c}
\hline \hline Fare, in Cents & Distance, in Miles & Passengers carried & Percentage \\
\cline { 2 - 4 } 2 & 2.3 & $97,697,000$ & 89.33 \\
4 & $?$ & II,I I 9,000 & 10.16 \\
6 & $?$ & 497,000 & 0.45 \\
8 & $?$ & 36,000 & 0.03 \\
10 & 6 & 4,000 & 0.01 \\
& & $109,353,000$ & 100.00 \\
\hline
\end{tabular}

$\ddagger$ Census of England and Wales, Igor. General Report, with Appendices.

$\S$ September 2, 1904 . 


\section{MUNICIPAL OWNERSHIP IN GREAT BRITAIN}

adherents of municipal ownership. The episode illustrates how one step in the direction of public ownership tends inevitably to lead to others. Says The Municipal Journal: "Glasgow Corporation, on the motion of Mr. Ferguson, has passed a resolution instructing the Committee on Land Values to inquire into the desirability of the Corporation obtaining possession of all the land outside its boundaries along which the tramways are carried. This is an exceedingly important phase of the Land Values question, and one that we hope will receive the attention of all public bodies who own or are thinking of owning tramways. Hundreds of acres of pasture land are being converted into 'ripe building land' by the action of local authorities in constructing tramways, and almost the whole of the 'unearned increment' which accrues goes into the pockets of people who have merely been smart enough to buy the property and erect houses upon it. The question is a very difficult one, but the difficulties have been surmounted in Germany,* where I Ioo cities and towns are at this moment having all their rates paid because they have become owners of the land outside their boundaries along which tramways

* In the days of Adam Smith, speakers and writers on questions of public policy, when confronted with perplexing problems, used to surmount the difficulty by saying, "It has been done in China." The public speakers and writers of to-day make a similar use of Germany, Australia, and New Zealand, countries concerning which the general public has acquired more misinformation than an energetic and wellinformed man could correct in a lifetime. 
have been carried.* There are plenty of ways of relieving the ratepayers' burdens in this country if the public would only face the position and apply bold remedies. This is one of them. The arguments apply, of course, whether it be a company or a local authority owning the tramway. In the former case, the tramway rights belong to the community, although they are exercised by a private combination, and it is equally the public which create the increment that at present goes into the pockets of those who have done nothing whatever to earn it."

It is a matter of common knowledge that in the United States the extension of the trolley lines has increased enormously the value of the distant outlying lands, and that it has at the same time frequently arrested the increase in value, or actually impaired the value, of the lands lying in the outskirts of the cities as they existed under the horsecar régime. In the Glasgow City Council it has been argued repeatedly that the city of Glasgow ought not to extend the street railways into suburbs that are not a part of Glasgow; as such action would cause people and industries to move out of Glasgow proper and thus decrease the taxable value of Glasgow proper. $\dagger$

* In October, I904, there were in Germany only I 38 cities, towns, and districts which had electric street railways. The total route-mileage was 2369 miles; and the total track-mileage was 3544 miles.

$\dagger$ Eisenbahntechnische Zeitschrift, June 7, I905. This same question has come up in Germany; and has led a recent contributor to the foregoing journal to construct the subjoined table, which shows clearly the 
Ilford is a city of $4 \mathrm{I}, 000$ people and lies in the outlying regions of Greater London. At the close of 1904 it had nine miles of street railway track; and some of its pleasantest parts were not built upon because they were without means of conveyance to the railway station and to the centre of the city. "In February, 1904, the ratepayers of Ilford, by a large majority at the poll, rejected the city's proposals for an extension of the existing tramways, after having, at the statutory meeting, ridiculed the assurances of the Chairman of the Tramways Committee that the tramways were doing excellent business, and would show good results at the end of the first half-year. . . The objection (urged against extending the tramways) which has met with the greatest amount of support, is that tramwaysought not to be laid to benefit the developers of new estates." * effect of the "exodus to the suburbs" on the tax-raising power of the city proper.

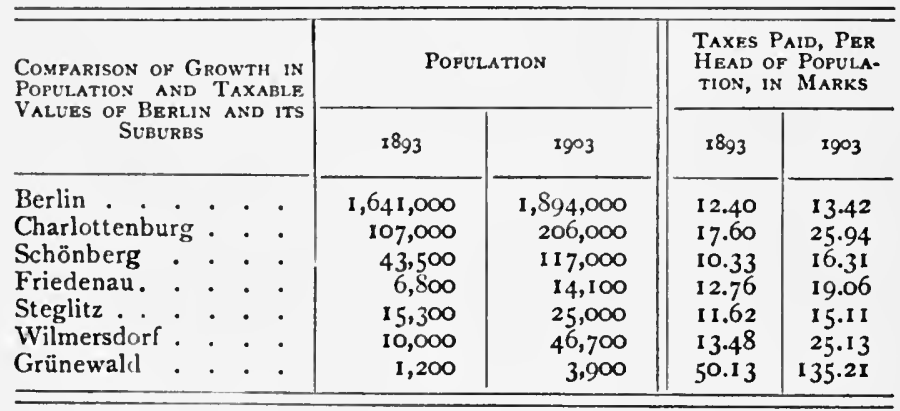

* The Municipal Journal, April 22, rgo4. 


\section{CHAPTER VII}

\section{EDINBURGH}

IN I870, the Lord Provost of Edinburgh called a meeting of the citizens to consider the question of improving the housing of the poorer classes. At that meeting the Lord Provost appointed Dr. Alexander Wood chairman of a committee to inquire into the state of the poorer classes. The committee found that, while the town as a whole was not overcrowded, certain districts were enormously congested. Dr. Wood and Mr. Charles Cowan, then member of Parliament for Edinburgh, thought that it would be better to give the inhabitants of the congested districts a chance to spread out than it would be to tear down the unsanitary houses in which they were living and build sanitary ones. Accordingly, they inspected the tramways in London, Liverpool, and Birkenhead. They were so favorably impressed that they returned to Edinburgh and organized the Edinburgh Street Tramways Co. for the express purpose of spreading out the population.*

* Report of Committee on Tramways (Use of Mechanical Power) Bills, 1878, q. 1009, testimony of Dr. A. Wood. 
The company from the start considered the needs of the so-called working classes. It charged a uniform fare of 4 cents, but carried working men and The Tramways, women at the rate of I cent a mile under Private Management, favor Working Classes until 8 or 9 o'clock in the morning, from $I 2$ to $I$ in the afternoon, and from 5 to 6 in the evening. On certain routes used largely by the working classes the company made a uniform charge of 2 cents a ride. It so successfully studied the needs of the people that Edinburgh became one of the few cities of Great Britain - if not the only one - from the streets of which the omnibus had completely disappeared in $1878 . *$ But subsequently, after the city had paralyzed the Edinburgh Street Tramways Co., the omnibus returned.

The company heeded the prejudices of the rich, who deemed the street railway a nuisance because it jarred them to cross it in their carriages, as carefully as it studied the needs of the classes. In the retail shop district it laid down turn-outs in order that the passing street cars might turn out for the carriages standing in front of the shops. $\dagger$

Though the Edinburgh Street Tramways Co. was started, in part, from philanthropic motives,

\footnotetext{
* Report from the Committee on Tramways (Use of Mechanical Power) Bills, 1878 , q. 1072, 1073, and 1054 to 1057 .

$\dagger$ Report of Lords Commillee on the Regulations which it may be desirable to impose in relation to the Construction and Use of Tramways, $1878-79 ;$ q. 1142 .
} 
and though it continued to be managed with great Development re- public spirit and intelligence, the tarded by Opposi- Corporation of Edinburgh, from the tion of City beginning to the end, treated the company as an institution to be thwarted and bled.

In I877, Mr. D. W. Paterson, Secretary of the Edinburgh Street Tramways.Co., testified before a Committee of Parliament that the company had been obliged to conciliate the corporation by making many payments not called for by the Tramways Act, I870. On one occasion $\$_{15}, 000$ for additional paving; on other occasions the company had been obliged to pave the whole street; on another occasion the Corporation had asked the company to pay $\$ 25,000$ toward the widening of a bridge, but, not being able to exact that sum, had accepted \$I2,500. The Secretary added that, in spite of making all these payments, the company frequently had been unable to get the Corporation's consent to making extensions which had been demanded by owners of land in the suburbs, and would have made available for building purposes hundreds upon hundreds of acres of land. He concluded with the words: "Tramway construction will be stopped practically unless an appeal is given from the refusal of consent of the local authorities to somebody not actuated by local and personal prejudices as the local and road authorities are apt to be." *

* Report of Committee on Regulations as to the Use of Steam or other Mechanical Power upon Tramways and Public Roads, 1877; q. 926 to 101 7 . 
In 1878 , Dr. Wood, chairman of the tramway company, testified as follows before a Parliamentary Committee: "We have been unfortunate in Edinburgh, though not singular (exceptional), in having had a great deal of opposition from the local authorities. ... We never have gone in for an improvement of our tramways without having had to pay money or make some concession. I can give many instances, but will restrict myself to one, which will show how the local authorities deal with us. We have two such authorities in Edinburgh, the Town Council and the Road Trust. Our charter authorized us to build from Edinburgh to Trinity, to the west of Leith. After getting the charter, we had General Hutchinson, of the Board of Trade, come down to tell us unofficially whether we could lay the track (to Trinity) with a grade of I in Io. General Hutchinson said: "You may lay the rail, but the Board of Trade will never sanction your working a grade of I in Io.' The Town Council then requested us to abandon that part of our line, and we agreed at once. Accordingly, in 1874 , we put into Parliament an Abandonment Bill. The Town Council supported it before Parliament, but at the eleventh hour the Road Trust sent up a deputation to Parliament, and said to the promoters of the Bill : 'Unless you pay us $\$_{15,000}$ (toward the cost of certain street widenings) and agree to remove your lines from a certain street (alleged to be too 
narrow for street railways), we will oppose your Bill.' We had had a great deal of litigation over the question of our right to lay the line which the Road Trustees wished us to remove, and the House of Lords (the highest Court of Appeal) had just decided the matter in our favor; and yet, we were obliged to pay that $\$_{15}, 000$ for nothing more than to get rid of the opposition; and to remove a portion of our line which the House of Lords had decided we had a legal right to lay. . . . I can give, if it is necessary, but I do not like to say unpleasant things, a great many more instances of the way in which we have been treated by the local authorities." The witness concluded with the statement that the company paid annually upon I 3 miles of tramway nearly $\$ 2500$ per mile in taxes and for maintenance of the streets, often being obliged to pave and maintain a larger part of the street than the Tramways Act, I870, demanded that the street railway companies should pave and maintain.*

In I879, Mr. Paterson, Secretary of the Edinburgh Street Tramways Co., repeated before a Committee of Parliament the testimony which he had given in 1877 . He added that the Town Council had refused to consent to the company doubling its track between Leith and Portobello. The Council would give no reason for its refusal, but one of the

* Report of Committee on Tramways (Use of Mechanical Power) Bills, 1878; q. 1024 to 1044 . 


\section{MUNICIPAL OWNERSHIP IN GREAT BRITAIN}

Road Trustees had said in private that the Council feared that if Parliament should grant power to lay a second track, it would subsequently grant leave to use steam power between Edinburgh and Portobello. The line in question was carrying a million passengers a year. The Secretary stated that with the facilities that could be afforded with a double track, the traffic would double, for Portobello was a very desirable suburb, lacking nothing but adequate transportation facilities. In reply to the query whether the company intended to extend its lines and to enter fresh districts, the Secretary replied: "We have made various attempts at the earnest solicitations of various parties in the suburbs to extend our system, but we have failed. We have been unsuccessful in two attempts to get the necessary consent from the local and road authorities, notwithstanding that the people in the districts desired the extensions." *

In 1877 , the city of Edinburgh defeated before the House of Lords a bill that had passed the House of Commons and authorized the use of steam on the tramway between Edinburgh and Portobello, "because it suspected that the time would soon come when an attempt would be made to introduce them throughout our streets as well." $\dagger$

* Report of Lords Committee on the Regulations which it may be desirable to impose in relation to the Construction and Use of Tramways, 1878-79; q. I095, I 105, I 1 08, I I 30, I I 27, and I 167.

$\dagger$ Report of Committce on Regulations as to the Use of Steam or other Mechanical Power upon Tramways and Public Roads, 1877; q. 2175, Sir James Falshaw, Lord Provost of Edinburgh from 1874 to 1877 . 
In 1877 to 1879 Edinburgh and other cities evinced such opposition to the use of steam on tramways that the British Parliament committees of 1877 , I878, and 1879 reported in favor of such a law.

Early in 1877 the Edinburgh Street Tramways Co. conducted some experiments with the use of steam. General Hutchinson, Inspector of the Board of Trade, witnessed the experiments and found that the steam tranways were "very manageable" and could be operated with safety to the passengers as well as the occupants of vehicles drawn by horses.* The members of the Edinburgh Town Council refused to witness those experiments or to send the city engineer to witness them. $f$ Later in the year the city of Edinburgh sent its Lord Provost, Sir James Falshaw, to London to argue before a Parliamentary Committee that the Edinburgh experiments with steam had not been successful. Sir James Falshaw's argument was that the steep gradients in Edinburgh made the use of steam unsafe, alleging that the engineers had not yet devised a safe brake. He maintained - in opposition to the cxpert witnesses - that the horse cars were held back in part by the horses, and not by the brakes

* Report of Lords Committee on the Regulations which it may be desirable to impose in relation to the Construction and Use of Tramways, 1878-79; q. 174; and Report of Committee on Tramways (Use of Mechanical Power) Bills, 1878 ; q. 523 to 596 .

+ Report of Committee on Regulations as to the Use of Steam or other Mechanical Power upon Tramierys and Public Roads, 1877; q. 2144 to 2 146, and 2 I82, Sir James Falshaw, Lord Provost. 


\section{MUNICIPAL OWNERSHIP IN GREAT BRITAIN}

exclusively. He argued that the streets of Edinburgh must not be used by the tramway company for the purpose of gaining the experience which he alleged was required for the devising of a perfect brake. He argued that the tramway company ought to go out into the country, purchase some fields with hills in them, lay down tracks on those hills, and gain the experience required for the perfecting of the brake. But he added that the Corporation of Glasgow would not necessarily accept the results of such experience gained in the fields, on the ground that those were "conditions of the weather and of the rails and of the streets which might not occur in the fields, and which might be extremely dangerous." * It is scarcely necessary to add that these arguments were advanced by Sir James Falshaw, the politician. Sir James Falshaw, the lawyer and director in the North British Railway, was a person of good sense.

Sir James Falshaw and his followers and successors ultimately convinced the tramway company that it was useless to seek to realize the ideal with which Company, dis- it had set out in 1871 : to build a couraged, sells street railway system which should Plant to City decentralize the overcrowded population of Edinburgh. The company gave up the struggle, sat down and awaited the expiration of

* Report of Committee on Regulations as to the Use of Steam or other Mechanical Ponver upon Tramways and Public Roads, 1877; q. 2113 to $215 \mathrm{r}$, Sir James Falshaw. 
its charters and the compulsory sale of its plant to the city on the basis of cost of replacement, less allowance for depreciation.

In the period from I894 to 1902 the city of Edinburgh bought those portions of the Edinburgh Street Tramways Co.'s lines which lay within the city limits and upon which the charters expired in the period in question - 24.5 miles of track in all. The lines lying outside of the city limits were left on the hands of the company. They were, of course, worthless, hanging in the air as they did. In I90I to 1903 the company operated eight or nine miles of track upon which the operating expenses exceeded the receipts by $\$ 4720$. Early in 1904, The $M u$ nicipal Journal* announced, under the heading, "A Good Municipal Bargain," that the city of Leith had purchased the remaining lines of the Edinburgh Street Tramways Co. for $\$ 300,000$, "which is stated to be less than the company paid for the tramways."

The city of Edinburgh bought 24.5 miles of track, built an additional 22.5 miles, and finally, in 1897 and the subsequent years, it converted its 45 miles of track from a horse car system to a cable system. In December, I904, the 405,000 people living in Edinburgh, Leith, and Portobello, had at their service 47 miles of track of cable line and 8 miles of track of horse line, or I mile of street railway track for each 7400 people.

* February 5, I904. 
The census of I90I showed that Edinburgh proper had a population of 3I7,000. There were living in the overcrowded condition of 3 to 10 persons in one room not less than 17,399 persons; and in the overcrowded condition of 5 to 12 persons, or more, in two rooms, not less than 57,193 persons.*

Immediately after Edinburgh had purchased the tramways of the Edinburgh Street Tramways Co., it leased them to the Edinburgh \& District Tramways Co., Ltd. A few years afterward it sent its Lord Provast to the United States to report on the American street railways. After the corporation had received the Lord Provost's report, it decided, in I 896, to adopt the cable system, which was then being

${ }^{*} 5,283$ persons living 3 to $\mathrm{I}$ room.

4,756 persons living 4 to $I$ room.

3,536 persons living 5 to 1 room.

2, I06 persons living 6 to $I$ room.

1,029 persons living 7 to $I$ room.

827 persons living 8 to 10 in 1 room.

16,145 persons living 5 to 2 rooms.

14,736 persons living 6 to 2 rooms.

11,662 persons living 7 to 2 rooms.

7,336 persons living 8 to 2 rooms.

4,419 persons living 9 to 2 rooms.

$\mathbf{2 , 8 9 5}$ persons living 10 to 12 to 2 rooms.

\begin{tabular}{c|c|c|c}
\hline \hline & $\begin{array}{c}\text { Overcrowded one- } \\
\text { room dwellers }\end{array}$ & $\begin{array}{c}\text { Overcrowded two- } \\
\text { room dwellers }\end{array}$ & Total population \\
\cline { 2 - 4 } 1871 & 31,416 & 35,813 & 196,500 \\
1891 & 20,864 & 49,224 & 261,300 \\
1901 & 17,399 & 57,193 & 316,500 \\
\hline
\end{tabular}


abandoned in the United States.* The Corporation condemned the overhead trolley system as unsightly, and it deemed the underground electric conduit a mere experiment.

The city made a contract with the Edinburgh and District Co. whereby the former was to equip the street railways for cable traction, and the latter was

Unbusinesslike

Management by Municipality to pay an annual rental of 7 per cent upon the combined cost of the existing horse car system $-\$ 1,065,000-$ and the completed cable system. The amount that the city was to spend upon the conversion from horse traction to cable traction was left undeterminate, but it was estimated at about $\$ 3,900,000$. The company believed that it could rely upon the city being willing and able to do the work in a businesslike manner and at a reasonable cost. The faith of the company proved to be entirely misplaced. The city's incompetence and extravagance raised the cost of the installation of the cable system to upwards of $\$ 5,850,000$, which was fully 50 per cent in excess of what the work would have cost a private company.

* Street and Electric Railways, United States Census Bulletin: 3, I903.

Cable Street Railways in Operation in the United States 
At the close of the year 1904, the Edinburgh and District Tramways Co., Ltd., had not succeeded in developing sufficient traffic to earn the rental which it was paying upon the inflated expenditure upon the city's street railway system. At the close of 1903 the company had spent $\$ 709,6$ I $_{5}$ in equipping the street railways with a rolling-stock, etc. It had raised that sum by issuing $\$ 462,500$ of stock, fully paid; $\$ 248,500$ of 4 per cent mortgages; and $\$ 250,000$ of 6 per cent mortgages. At the close of I904, the stockholders had had no returns from their investment. The comparatively poor opinion which investors have of the bargain made by the company is shown by the fact that when the company had to raise money in 1902 , it was obliged to pay 6 per cent, an indication of second-rate credit. There is great rejoicing in Edinburgh, for the city is making money in addition to having "soaked" the operating company, to repeat the word recently employed by an officer of the Corporation of Edinburgh.

The reasons why it cost the city of Edinburgh fully 50 per cent more than it would have cost a private company to equip the street railways for cable traction are indicated in a recent interview of Sir Robert Cranston, Lord Provost of Edinburgh, by Mr. Raymond, special correspondent of the Chicago Tribune.* In reply to the query why the city should

$$
\text { * May } 15,1905 .
$$


not operate the tramways, the Lord Provost said: "So long as the road is under municipal management there is always a temptation to provide employment in some way for political hangers-on, and they are not generally the class of people who are profitable to hire. ... We consider ourselves free from political influence here in Scotland, but I must confess that now and then influences are brought to bear to secure employment in municipal plants which are not entirely worthy. For instance, if I were running for reëlection to the Town Council, and Consul Flemming here, whom I knew to be possessed of great personal influence in my ward, should come to me and make a point of the employment of some man on our tramway system, I would be likely to take that man in preference to an unknown applicant, unless I resisted the temptation strongly. That is the great danger to be faced in the operation of any municipal system. . . . Not only an honest but an economical administration of the tramway system is indispensable to success. The private companies are better adapted to run such systems, because they realize that the result of the employment of incompetent men will be to reduce their own profits. It would be quite possible for you to have a municipally owned and operated tram system which would be conducted with scrupulous honesty and yet would be a failure. Every penny of fare might be collected and every dollar of expense 
130 MUNICIPAL OWNERSHIP IN GREAT BRITAIN might be properly accounted for, and yet at the same time the employment of incompetent men in responsible positions would be almost as bad for the public as if they were dishonest." 


\section{CHAPTER VIII}

\section{BIRMINGHAM}

Mr. Joseph Chamberlain, Mayor of Birmingham, in 1874 , in a speech in the Birmingham Town Council, proposed the municipalization of the gas works in these words: "I distinctly hold that all monopolies which are sustained in any way by the State ought to be in the hands of the representatives of the people, by the representative authority should they be administered, and to them should the profits go, and not to private speculators. In the second place ... I am always inclined to magnify my office (of Mayor). I am inclined to increase the duties and responsibilities of the city government, in whom I have myself so great a confidence, and I will do everything in my power to constitute these city governments real local parliaments, supreme in their special jurisdiction." Under the influence of the spirit thus vigorously expressed by Mr. Chamberlain, Birmingham has surpassed all other British cities in going behind and overriding the Tramways Act, I87o. That act, it will be remembered, gave the local authority concerned the right to veto any appli- 
cation from a company to the Board of Trade for a charter for a street railway. But it was the intention of the act that, if a local authority should give its consent to the Board of Trade issuing a street railway charter to a company, it should give it without qualification, in consideration of the charter providing for compulsory sale at structural value at the close of twenty-one years.

Birmingham gives its consent only on the following conditions: The city is to build the street railway for which the company holds the charter, and the Building of completed property is to be held by Street Railways the company on the following terms. discouraged The payment for the first fourteen years of an annual rental of 4 per cent on the cost of the street railway, and the payment for the last seven years of an annual rental of 5 per cent. In addition, the company pays each year into a sinking fund, which is the property of the city, a sum equivalent to 2.874 per cent of the cost of the street railway. That sum, at compound interest, at the expiration of twenty-one years, will equal the city's outlay upon the street railway. In other words, at the end of twenty-one years the city will have recovered the capital invested in the street railway, and in the meantime it will have received respectively 4 per cent and 5 per cent upon its investment. Moreover, the city at all times will be, for all practical purposes, exempt from the possibility of losing any 
part of the capital invested; for the company must guarantee the fulfilment of the agreement to pay respectively 4 per cent and 5 per cent a year, by depositing with the city in cash 50 per cent of the cost of the street railway. To sum up: for doing nothing and for assuming no risk, the city gets respectively 4 per cent and 5 per cent on the cost of the street railway, and is repaid its whole outlay in the course of twenty-one years.*

The city builds only the street railway proper, and the company holding the franchise must provide the buildings, rolling stock, and other necessary equipment. At the expiration of the twenty-one year franchise the city is under no obligation to purchase any part of the company's equipment. The capital invested by the company in the equipment can obtain no return until all operating expenses have been paid, including sinking fund payments on the equipment, and the city has been paid respectively 6.874 per cent and 7.874 per cent upon the cost of the street railway proper.

Upon these onerous terms, capitalists have, of course, been very reluctant to embark in street railway ventures in Birmingham. At the close of r904, Birmingham and its suburbs, with a population of $1,287,000$ persons, had only 148.5 miles of street railway track, or one mile of track for each

* Report of Lords Committee on the Electric Light Act, I882, Amendment Bills, I886; q. I 327 to 1338 , E. O. Smith, Town Clerk of Birmingham since I88I. See also: The Municipal Y'ear Book, I904, p. 335 . 
8700 inhabitants. The census of r9or showed that there were living in Birmingham proper in the Lack of Transit overcrowded condition of more than Facilities and two persons in one room, not less than Overcrowding 53,936 persons, or 10.33 per cent of the population. In Dudley, a part of Greater Birmingham, were living in an overcrowded condition 85 I9 persons, or 17.48 per cent of the population. In West Broomwich, a part of Greater Birmingham, were living in an overcrowded condition 6464 persons, or ro.2 per cent of the population. Summarizing this matter, one finds that in Birmingham proper and its seven leading outlying cities or towns, there were living in an overcrowded condition 84,295 people, or 8.4 per cent of the population.

The street railways in Birmingham proper still are operated mainly by horse power and steam power. The corporation has decided not to entertain any proposals from the companies at present holding franchises to convert to electric traction,* but to let the present franchises run out, and then to convert to electric traction and assume operation. The principal franchises will expire in I906. The corporation, doubtless, will adhere to its past policy of looking upon the street railway, not as an agency for the promotion of the decentralization of the population, but as an agency that can be made to turn

* The Municipal Year Book, 1904, p. 336. 
money into the public treasury. But while the people of Birmingham will merely be "churned up within the city limits" and will not be permitted to escape beyond those limits, they doubtless will derive much comfort from indulging the habit of reflecting upon the fact that they are not being exploited by "private speculators," to use the telling slogan of that astute politician, Mr. Joseph Chamberlain. 


\section{CHAPTER IX}

MANCHESTER, LEEDS, LIVERPOOL, SHEFFIELD, AND BRISTOL

MANCHester leased the city tramways to a company in 1875 , the lease to expire in I901. It failed to make it worth while for the lessee to convert to electric traction, with the result that horse traction was retained until after r9or. At the close of I904, Manchester, with its suburbs, had 673,000 inhabitants, and I 50 miles of electric street railway track, or one mile for each 4500 people. In I90I, there were living in Manchester proper, 34,147 "overcrowded" persons, or 6.28 per cent of the population. In I900, Alderman Southern, who for twenty-two years had been a member of the Manchester City Council, testified as follows before a Parliamentary Committee: "Now we have, of course, outside the city, plenty of useful building land, where, if these workmen could get to and from their work cheaply and quickly, no doubt a very large proportion of our congested population would be moved outside the city.... The real key to that question of overcrowding lies in quick and rapid transit 
to the suburbs." * In June, I904, Mr. McElroy, General Manager of the Manchester Municipal Tramways, testified before a Select Committee of the House of Commons, that "in Manchester the trams ran out from four to six miles in every direction, and the number of passengers who paid the full fare of 8 cents for the long distance-was only 0.25 per cent of the whole. Tramway managers knew that longdistance passengers were a negligible quantity." $\dagger$ This statement was made in support of the argument that it was not necessary, in the public interest, for Parliament to give the Tyneside Tramways and Tramroads Co. compulsory running powers over certain of the tramways belonging to the city of Newcastle. The company had asked these powers in order that it might develop traffic between Newcastle and Tyneside. In 1904, Newcastle had one mile of track for each 5500 inhabitants; and in rgor there were living in Newcastle in an overcrowded condition, 65,605 people, or 30.47 per cent of the population. Mr. John Young, Manager of the Glasgow Municipal Tramways, supported Mr. McElroy. In 1904, the city of Manchester had spent upon its street railways the sum of $\$ 7,428,000$, which called for $\$ 263,555$ interest. After paying that interest and sinking fund contributions, and crediting the reserve renewals and depreciation

* Report from the Joint Select Committee on Municipal Trading, 1900; q. 2403 to 2415 .

$\dagger$ The Municipal Journal, June 10, 1904. 
account with $\$ 350,000$, the city had left $\$ 250,000$ which it contributed "in relief of the rates." * It is obvious that, if the city should abandon the policy of operating the street railways primarily in the interest of the taxpayer, it could give great relief to the congested population by more than doubling the present street railway mileage. The surplus of $\$ 250,000$ earned by the existing street railways would "carry" a large mileage of street railways that earned no more than operating expenses or not even that much.

\section{LEEDS}

The city of Leeds purchased the street railways from the company in 1894 . It postponed until I 897 the conversion to electric traction. At the close of 1894 it had 437,000 inhabitants and 82 miles of street railway track, or one mile for each 5300 people. In 1901, not less than ro.08 per cent of the population, or 43,239 persons, lived in an overcrowded condition. In 1900, Mr. W. J. Jeeves, town clerk of Leeds, testified as follows before a Parliamentary Committee: "Then when we come to tramways, there again I am more and more convinced that they are an absolute necessity in large communities; and, as a matter of fact, I see no other possible solution of the difficulty of housing the working classes, indeed I may say the housing of

* The Municipal Journal, July 8, I904. 
the bulk of the community, not merely the working classes, but clerks and so on." *

In 1903 the city of Leeds had expended upon the street railways $\$ 5,200,000$. In that year it paid in interest $\$ 133,335$; contributed $\$ 71,935$ to the sinking fund ; laid aside $\$ 70,520$ for depreciation, and had left a balance of $\$ 310,000$. The latter sum would justify the city of Leeds more than doubling the street railway mileage which it now puts at the service of its citizens.

\section{LIVERPOOL}

Liverpool purchased the tramways in 1897 , and equipped them for electric traction in 1898 . At the close of 1904, Liverpool and its suburbs had 673,000 people and Io3 miles of street railway track, or one mile of track for each 7400 people. At the close of I902, the city's investment in street railways was $\$ 9,165,000$. After paying interest and sinking fund charges, contributing $\$ \mathrm{I} 40,000$ to a reconstruction and extension fund, as well as $\$ 250,000$ to a reserve fund, the tramway contributed $\$ 125,000$ "in aid of the rates."

\section{SHEFFIELD}

The city of Sheffield began the conversion to electricity in 1899 , and had not completed it in March, I903. At the close of 1904, Sheffield had

* Report from the Joint Select Committee on Municipal Trading, I900; q. 3046 . 
412,000 inhabitants and 65 miles of street railway track, or one mile for each 6300 inhabitants. In I90I there were living in Sheffield in an overcrowded condition not less than 36, I59 persons, or 9.5 per cent of the population.

\section{BRISTOL}

Bristol is the only large English city in which the street railways are owned by a company. The company obtained its first charter in 1872 ; charters for additional lines were obtained in $1875,1876,1877$, I879, I880, I881, I882, I887, I890, I894, I896, I 897 , and 1898 . Some time after the city had the right to purchase that part of the lines covered by the original charter, the city made a contract with the company agreeing not to purchase the original lines before I9I5, nor to purchase the later lines before I 918 and 1928 respectively.* On the strength of that agreement, the company began the conversion to electric traction in 1895 , and felt justified in giving the public, by the close of 1904, 57 miles of street railway track, or one mile of track for each 5700 people. A still longer extension of the charter, together with the waiving of the compulsion to sell at structural value, would have induced the company to provide more liberal facilities. In I90I there were living in a overcrowded condition in Bristol, I I 687 persons, or 3.55 per cent of the population. IgO4.

* Duncan's Manual of Tramways, Omnibuses, and Electric Railways, 


\section{CHAPTER X}

\section{GREATER LONDON *}

SHORTLY after the Tramways Act, 1870, was passed, companies applied for charters for tramways in 93 miles of street of Metropolitan London. $\dagger$ The Metropolitan Board of Works was one of the local authorities whose consent had to be obtained, and it rejected applications covering 28 miles of street. The motives of the Metropolitan Board of Works are illuminating. To begin with, the Board stated that the tramway traffic had developed to an extent the Board had not anticipated. The advantages to the public from the increased facilities and the lowering of the omnibus fares $\ddagger$ were so great that "it was an absolute necessity that they be extended as far as possibly could be done, for the general convenience of the public." The Board was much impressed with the argument that

* Area, 693 square miles; population at the close of $1904,6,833, \infty 00$.

† Metropolitan London at that time had an area of 117 square miles.

$\ddagger$ Report of Committee on Metropolitan Tramways, 1872; q. II. George Hopkins, Engineer to Tramway Companies in London, Dublin, Liverpool, and Glasgow: "In London the tramways already have reduced the omnibus fares by one-half." 


\section{MUNICIPAL OWNERSHIP IN GREAT BRITAIN}

the tramways should be used for the purpose of carrying the people to and from the suburbs. Therefore it gave its consent to almost all the suburban lines. Nevertheless the Board refused consent for many lines which were to give the suburban lines access to the heart of the city, and thus left the suburban lines hanging in the air. The Board refused that consent because it had had "very influential deputations from shop-keepers in streets used by the carriages of the wealthy" and in other cases because it believed that the establishment of tramways "would deteriorate the value of property." The Board of Works also acted on the doctrine that it was not necessary to build tramways in streets along which the omnibuses had not established routes. Where there were no omnibuses, there was no traffic; and where there was no traffic, there was no need of tramways, argued the Metropolitan Board of Works.*

It was necessary to get the consent of every vestry concerned, as well as that of the Metropolitan Board of Works. Some vestries were ready to sell their

Local and Class Interests check Development of Tramways consent, others refused it on the ground that charters should not be given to "private speculators," and still others refused it on the ground "that the tramway question was not yet sufficiently advanced to

* Report of Committee on Metropolitan Tramways, ' 872 , q. 449, 452, $47 \mathrm{I}, 473,453$, and 459, testimony of Mr. William Newton, late Chairman of the Parliamentary Committee of the Metropolitan Board of Works. See also $q .787,788$, and 1172 . 
enable them to come to any decision upon it." * As early as May, I87 I, the Board of Trade reported : "It will be seen from the above report, that under the conditions imposed by the Act of last session, the Board of Trade have been unable to lay before Parliament a complete and perfect scheme for tramways in the metropolis. And it will be obvious that in the present state of divided jurisdiction between the city of London, the Metropolitan Board, and the Vestries, it is impossible to look for any such united action on the part of the authorities as is necessary for the maturing of a perfect scheme, and as may be found in other places where there is one supreme municipal authority." But down to this day, September, I905, the British Parliament has not dared to go counter to the local and class interests that oppose the enactment of a law under which it would be possible to supply Metropolitan London with street railways.

In 1871 and 1872 it was often suggested that the Metropolitan Board of Works put an end to the evils arising from divided jurisdiction by asking Parliament to give the Board exclusive control of the streets in order that the Board might itself build a unified and comprehensive system of tramways. But the Metropolitan Board replied that its members were appointed to the Board by the Vestries, and

* Tramways (Metropolis). Report of the Proceedings of the Board of Trade under the Tramways Act, I870, with regard to the Proposed Tramways in and about the Metropolis. Document No. 21 I, I87I. 


\section{MUNICIPAL OWNERSHIP IN GREAT BRITAIN}

that if the Board should take any such radical action "there would be likely to be a big change in the make-up of the Board." * Again, to quote the words of Mr. William Newton, Chairman of the Parliamentary Committee of the Metropolitan Board of Works on Tramways: "In the uncertain state of the public mind as to whether tramways would be successful or not, it would have been almost impossible for a public and representative Board to have adopted the scheme at that time. The system was altogether undeveloped; there were grave doubts about its ultimate success, and altogether it was a speculative thing. . . . Again, if the Board had built to lease, there would not have been much competition among the persons desiring to become lessees because there were not many persons sanguine of the success of tramways; and altogether the Board considered that it would be better to allow private capital to develop the scheme. . . . And at the end of the twenty-one years, when we had all the experience that commercial enterprise would develop, we should be able to take possession." $\dagger$ These words of Mr. Newton describe the attitude which the British municipal authorities have taken successively to the horse tramway, the electric light, the electric tramway, the telephone, and the electric power plant. The

* Report of Committee on Metropolitan Tramways, 1872; q. I4I9, J. W. Bazalgette, Engineer to Metropolitan Board of Works.

$\dagger$ Report of Committee on Metropolitan Tramways, 1872; q. 450, Mr. William Newton. 
municipality can contribute nothing to progress, but must leave such work to commercial enterprise, which is invited to undertake the work of developing new industries on the basis of "heads I win, tails you lose," the municipality standing in the position of "I win."

In 1872 there were so many applications for charters for tramways in Metropolitan London that Parliament came to fear lest it had accorded too Parliamentary liberal terms in the Tramways Act, Committee of 1872 I 870 . Accordingly the House of Commons appointed a select committee of five members "to join with a committee of the Lords to inquire into the question of Metropolitan Tramways proposed to be sanctioned by Bills in the present session, and to report: whether it is desirable or not that any fresh tramways be laid within the metropolitan area; under what authority the construction and working of Metropolitan Tramways, if any, should be placed; along what lines of streets, if any, tramways should be allowed to be constructed, and under what restrictions." *

Before the Parliamentary Committee of 1872 , Captain H. W. Tyler, Inspecting Officer of the Board of Trade, testified that tramways tended to clear crowded streets and that Parliament should fix no minimum width as to streets in which tramways should be permitted. Mr. Newton, late Chair-

* Hansard's Parliamentary Debates, March 8, 1872, p. I620. 
man of the Parliamentary Committee of the Metropolitan Board of Works, said: "I do not think that the crowded nature of the thoroughfare has much to do with the question of whether a tramway should be laid. . . . If there is room for a vehicle to stand between the tramway and the kerb, a tramway is a regulator of the traffic rather than an obstructor." Mr. Haywood, Engineer to the Commissioners of Sewers (the road authority) for the city of London, said that it would be inadvisable for Parliament to lay down a minimum width as to streets in which tramways might be laid, for such action would restrict development.* The testimony of these witnesses was supported by the testimony given in $187 \mathrm{I}$ by the Superintendents of Police for the Divisions of Whitechapel, Stepney, Lambeth, Camberwell, and Greenwich, which, in turn, had been indorsed by the Board of Trade. $\dagger$

The tramway companies introduced evidence to the effect that "as the tramways were brought nearer to the heart of the city, the tramway for the whole distance was more generally used, proving the great importance to the public of getting to the great centres of traffic." They asked for permission to establish great through routes running north and

* Report of Committee on Metropolitan Tramways, 1872; q. I02I, ro89, 453, 455, 685, and $74 \mathrm{r}$.

† Tramways (Metropalis). Report of the Board of Trade under the Tramways $A c t, \mathrm{i} 870$, with regard to the Proposed Tramways in and about the Metropolis, Document No. 2 I I, I87 I. 
south and east and west, promising to give through tickets and other accommodations that would promote traffic. The Engineer to the Commissioners of Sewers for the city of London said that if a complete system of tramways were established, the omnibuses would disappear.*

Mr. J. W. Bazalgette, Engineer to the Metropolitan Board of Works, appeared before the Parliamentary Committee to advance the fantastic motion that the asphalt pavement soon would be brought to such a stage of perfection that the public would have no further need of street railways; that thereafter the street railway would be merely a nuisance, because it would be in the way of the ordinary vehicles which would move with such ease over the asphalt that the public would have no further need of street railways. $\dagger$ The Select Committee of 1872 indorsed this motion, and reported that it would be inexpedient by the establishment of vested interests in important streets to prejudice the introduction of new modes of laying down the surface (asphalt), which may have the effect of benefiting all kinds of traffic equally, without creating any monopoly in the use of the public thoroughfare.

The Select Committee reported: "The expediency of laying down any fresh tramways within

* Report of Committee on Metropolitan Tramways, 1872; q. 234, $252,689,605$ to $609,253,686$, and 337 .

$\dagger$ Report of Committee on Metropolitan Tramways, 1872 ; q. I38r, I408, 1409,1432 , and I433. 
the metropolitan area must in a great measure depend upon the nature of the roads or streets over which it is proposed to carry them. In the suburban districts some extension may be very desirable for the convenience of the public, but in the streets of the Metropolis, every extension should proceed with the greatest caution. . . . We are far from being insensible to the advantages attaching to the construction of tramways by an authority having entire control over the tramway and roadway, and able to devote the profits arising from the undertaking to the relief of the rates. We think it, however, premature to discuss in any detail the question of central management of Metropolitan Tramways by a municipal authority which has yet to be created, though we are of opinion that when such an authority is established, every facility should be afforded to enable it to obtain possession of the tramways by purchase upon fair terms, at the earliest period. . . . The committee finally are of opinion that the fullest consideration should be given by (future) committees (on Private Bills) to the interest of the public in the use of the streets as well as of the owners and occupiers of the adjoining houses. With these precautions, the committee do not see any objection to the construction of tramways by private enterprise."

The Bazalgette episode of 1872 recalls to mind the fact that at the present moment a number of British municipalities are checking the extension of 
the municipal tramways from apprehension lest the motor omnibus shall displace the tramways. Eastbourne, a city of 50,000 people, has gone so far as to refuse to install a street railway system; it gives the public a system of motor omnibuses. The Tramways Committee of Wolverhampton (population, 96,000) recently has recommended the abandoning of a proposed new tramway route and the installation of a motor omnibus service over the route in question.* The city council of Shoreditch, a part of Metropolitan London, having a population of 124,000 , recently passed the resolution: "That the London County Council, the borough councils north of the Thames, and the North Metropolitan Tramway Co., be requested to consider the possibility of adopting a system of automobile tramcars, driven by petrol or other engines, with a view to avoiding the heavy expense and immense public inconvenience and loss which will be caused by the construction of a conduit or overhead electric system. That the London County Council be requested to arrange with the North Metropolitan Tramway Co. for the trial of an experimental petrol or other motor car concurrently with the horse trams." $†$ South Shields has 97,000 inhabitants, and 3.25 miles of horse tramway, which are leased to a company. The city contemplates terminating the lease 
in I906. Since 1903 it has had authority from Parliament to build an additional twelve miles of track. In February, 1905, the Ratepayers' Association of South Shields passed a unanimous resolution urging the Town Council not to accept any tender for the laying down of tram lines until it had fully inquired into the advisability of running motor omnibuses in the place of the (contemplated) electric cars.* Early in February, I905, a "conference was held in London of representatives of municipalities owning tramways. Mr. Boyle (Chairman of the Manchester Corporation Tramway Committee) presided. The conference considered the clauses which several (steam) railway companies have introduced in their Bills for the present session of Parliament, enabling them to provide motor omnibuses, which they would be entitled to use without any restriction (i.e. in competition with tramways). A resolution was adopted condemning this proposal, but expressing the opinion that there would be no objection to it if the powers sought by the railway companies were limited to the provision of motor omnibuses carrying traffic to and from the companies' railway stations, subject to the proviso that such vehicles should be licensed by the local authority in whose district they are to be used." $\dagger$

Let us turn now from the consideration of the situa-

* The Municipal Journal, February 24, 1905.

† Ibid., February 17, 1905. 
tion in the early seventies to the consideration of the situation in more recent times. Let us begin with Recent Opposi- the arguments made in the House tion to Tramways by Private of Commons in $\mathrm{r} 89 \mathrm{I}$ and $\mathrm{r} 892$, in Interests each of which years the House defeated a Bill authorizing a street railway over Westminster Bridge for the purpose of connecting the tramways south and north of the Thames. In both cases the rejection of the Bill was moved by Sir Algernon Borthwick, "on behalf of the West End Ratepayers' Association, who have successfully defeated a series of these measures." * Sir Dixon-Hartland seconded the motion for rejection. His arguments were that the House should not allow a tramway company "to take possession of the best thoroughfare in London in order that they might realize a private profit from it," and that there was "nothing owners and drivers of carriages dislike more than the twisting of their wheels by the tramway metals." + General Fraser, representing the "Tradesmen of Westminster Bridge Road," opposed the Bill. Mr. Radcliffe Cooke informed the House that "one Honorable Member who is going to vote against the measure told me that in taking a certain drive in his carriage he had to pass over tram rails

* Hansard's Parliamentary Debates, May 7, 1891, p. 245; and February 29, I892, p. 1488 .

† Ibid., May 7, I891, p. 246; and February 29, 1892, p. 1474. DixonHartland, Sir F. J., Middlesex County Alderman and Chairman of Finance Committee; Director of London City and Midland Bank. -Who's Who, igo5. 
thirty-two times, and he was jolted very much." Mr. T. P. O'Connor* argued that tramcars wore out the roadway and thus raised the fares charged by the hansom cabs. He said that in New York City "it was impossible to go for any distance in a hansom for less than one dollar, and the reason was solely the wear and tear of the roads by the tramcars. I ask the House to set its face stolidly against these attempts to introduce the tramway system into the centre of London. London ought to be maintained as a comfortable place of residence, and certainly it will cease to be so, if this noisy tramway system is introduced all over the Metropolis. . . . If the working classes want to cross the bridge, they can find plenty of half-penny omnibuses to take them." Mr. Cunninghame Graham said: "Although I am most desirous that every facility should be afforded to the working classes for getting to their work, unless I receive an assurance that the company will limit the working hours to ten per day, I shall certainly vote for the Amendment" (to reject the Bill). Mr. Cremer, who represented Shoreditch, which has 35,529 persons, or 29.95 per cent of its population, living in an overcrowded condition, could not consent to relief being afforded by a company that would not accept the London County Council's dictation that the hours of work must be limited to ten a day.

* O'Connor, T. P., late editor of the Sun and Weekly Sun; editor of M.A.P. and T.P.'s Weekly. - Who's Who, 1905. 
In the House of Lords, Lord Carrington said: "And the frontagers are backed up by the Tramways Defence Association, which is an association interested in ordinary wheel traffic (i.e. of owners of omnibuses and cabs), and that is the old question rather, as in the old days, of stage-coaches against railroads. . . I I may say briefly that the congestion of traffic at the end of Westminster Bridge (caused by the tramway coming to a dead stop) is not only inconvenient, but it is a great and positive and serious danger. Besides the 5500 passengers carried every week in omnibuses over Westminster Bridge past this dead end (of the tramway, where the horses have to be taken out) there are 200,000 persons every week who have to get out of the trams and walk over the bridge. It matters not what the weather is, they must get out in the middle of the road, women and children, and walk through the mud. To help those people there are the half-penny omnibuses which your Lordships may see - the little omnibuses which carry ten persons, and which it is calculated pass the end of Parliament Street 777 times a day. Now if the tramway was allowed to pass this House and was made up to this end, all those omnibuses would be run off the road, of course."* Lord Lamington said: "If your Lordships think it desirable to have tramways throughout the West End, then you must vote for the Bill; but

* Hansard's Parliamentary Debates, June I4, I892, p. IoIr. 
otherwise you should not pass this Bill, because it is only an excuse for making a great centre for a general tramway system."

From the consideration of the nature of the opposition to tramways exercised by private interests, let us turn to the consideration of the character of Misuse of Veto the opposition exercised by the Power by Bor- public authorities, namely, the Metoughs and County ropolitan Boroughs, twenty-seven in Council number, and the London County Council. In I902, Mr. John Burns, a member of the House of Commons, as well as a member of the London County Council, spoke as follows: "In three sessions of Parliament thirty-eight proposals for extensions and improvements of tramways (proposed by the London County Council) have been vetoed by the Borough Councils in London. In nearly all those cases, the veto in my opinion was unreasonably exercised. Some of the vetoes by Borough Councils of County Council projects have been unreasonable; some have been factious and some have been almost on the verge of blackmailing the tramway authorities (the London County Council) for local street improvements to an extent the Borough Councils ought not to have been guilty of. . . . That is a very serious condition of things, and it can only be got over by tolerant and more harmonious relations between the County Council and the Borough Councils. ... The condition of things has been a scandal 
in the past, is a disgrace to the present, and ought to be avoided in the future. . . . Battersea should not be factiously allowed to prevent the people of Lambeth (of whom 36,904 , or $\mathbf{1} 2.22$ per cent, are overcrowded) from having access to Wandsworth Common, simply because the Wandsworth Borough Council, for political reasons, dislikes the London County Council." * In the course of the same debate, Sir J. Dickson-Poynder said: "He had often been told that he was an undue advocate of the London County Council. He probably thought there was more good in that body than did many of his honorable friends, but at the same time he was by no means blind to its defects. That body had laid down a principle - from which, under no circumstances, would it deviate - that all tramway schemes within the area of the London County should belong solely to the London County Council. If Borough Councils had in the past been arbitrary in the exercise of this power of veto on schemes promoted by the London County Council, so also had the latter body been most arbitrary in vetoing schemes, many of them most admirable schemes, promoted by private companies." $\dagger$

The Report of the Royal Commission upon the Means of Locomotion and Transport in London, July, 1905, says that the London County Coun-

* Hansard's Parliamentary Debates, May r5, r902, p. 447.

† Ibid., May I5, I902, p. 459. 
cil* has consistently used the power of veto to the exclusion of private promoters from the County of London, and that the Corporation of London $\dagger$ invariably has used its power of veto against all comers. The report adds that "the strongest opposition to the abolition of the veto comes from the Corporation of the city of London and its officers. The London County Council would like to see the right of veto abolished in the case of the Metropolitan Borough Councils and the Corporation of the city, but wishes to retain its own right of veto against the private promotion, and objects to submitting its tramway schemes to a Traffic Board, preferring that they should go direct to Parliament.

"On the other hand, independent witnesses, whose experience gives great weight to their testimony, are in favor of the abolition of the veto. Mr. J. W. Lowther, M.P., at the time Chairman of Committees and now Speaker of the House of Commons, expressed a strong opinion that the power of vetoing tramways had worked a great deal of mischief; that the Standing Order had been most improperly used for the purpose of extorting all sorts of terms and conditions from tramway companies, and had subjected them to liabilities and disabilities which were never contemplated by Parliament. Mr. Albert Gray, K.C., Counsel to the Chairman of Commit-

* The London County Council was established in 1889 , upon the abolition of the Metropolitan Board of Works.

† Area, one square mile. 
tees of the House of Lords, expressed the same opinion, and said that the veto was extremely detrimental to tramway enterprise, and bad for the municipal bodies themselves. We were, unfortunately, unable to obtain the evidence of the late Lord Morley, Chairman of Committees of the House of Lords, but we observe that both on August 2, I900, and July II, I90I, he expressed, in the House of Lords, opinions in favor of the abolition of the present right of veto by small local bodies, and added that, if the veto was placed in the hands of large bodies like County_Councils, much harm would not be done.

"There is no doubt that tramway development has been seriously checked by the operation of these vetoes, and, although it is not suggested that any unworthy use has been made of them in London, it is clear that the veto is sometimes exercised without due regard to the importance of establishing through tramway communication.

"We have come to the conclusion that the best course is to abolish the veto in all cases, but to provide that, in 'Greater London,' the County Councils and the Corporation of the city of London shall have a . preferential right to construct any tramways, within their districts, if they are prepared to do so. . . ."

At the close of 1904, Greater London, with an area of 693 square miles, and 6,833,000 inhabitants, 
had 203 route miles of street railway, or less than Inadequacy of one mile of track for each 16,800 Tramway Service people. "Insufficiency of mileage is not the only defect of the tramway service in London," adds the Royal Commission on the Means of Locomotion and Transport in London. "Within the County of London* nearly the whole of the tramways are owned, and in great part are worked, by the London County Council, whose policy has been consistently directed to the exclusion of private promoters from within the County of London; such tramways within their jurisdiction as do not already belong to them will be acquired, under existing statutory powers, in the course of a few years. In the districts of 'Greater London' + lying outside the Administrative County of London, a different policy in general prevails: the tramways are largely worked by private companies. This difference of policy would not necessarily entail inconvenience, if the systems on the outside were worked in harmony with those inside, so that cars could run continuously across the frontier. Unfortunately, that is not the case. The systems, where they meet at the frontier, are not always physically connected, and in no case is there through running. Accordingly, every through passenger is obliged to change cars (and pay a new fare).

* Area, I 7 square miles.

$\dagger$ Area of Greater London, which includes the County of London, is 693 square miles. 
"Inside the County of London itself, there are also very serious defects. Three systems of tramway are included in this area: the northern and eastern system, wholly north of the Thames; the western system, also wholly north of the Thames; and the southern system, wholly south of the Thames. All these three systems are separated from each other by long intervals, without any connection; while great districts in the centre of London, including the city, the 'West End,' and the chief places of public resort, are entirely unprovided with tramway service. The different lines approach those districts and then break off abruptly in the middle of the street. As a result, all the cars are obliged to discharge their passengers at dead-end terminals. At the six principal terminals, nearly a quarter of a million passengers alight from, or join, the cars every day in the streets. Apart from the great inconvenience caused to all or most of the passengers, the result is a great congestion, both of tramcars and of ordinary vehicular and passenger traffic, at these terminal points; and the same congestion, though in a less degree, occurs at the other terminals in London.

"The Advisory Board of Engineers estimate that the carrying power of a tramway system may be diminished by about one-half by reason of the crossshunting necessary at dead-end terminals. In the absence of delay from this cause, I 50 cars, or upward, per hour might be run on a single track, even in busy 


\section{MUNICIPAL OWNERSHIP IN GREAT BRITAIN}

thoroughfares; but at Westminster, for example, where a number of cars from different lines converge at the Lambeth end of Westminster Bridge, the necessity for cross-shunting creates so great a delay that all the lines taken together cannot run more than 72 cars per hour in one direction, and that only under pressure.

"It will be seen that, from every point of view, tramway accommodation is glaringly defective. In a great area, there is no tramway service at all. Where there is such a service, travellers do not obtain the full advantage which it ought to provide, in cheapness, expedition, and convenience. An 'endon' break in the course of a journey probably causes additional expense (for two independent fares usually cost more than a through fare), whilst the consequent delay and discomfort, especially in bad weather, and the uncertainty of trans-shipment, are great drawbacks. Where the line abruptly terminates in the middle of crowded streets, even greater discomfort is caused, together with serious diminution of efficiency in the entire tramway service, and an intolerable congestion in the streets."

By way of comment upon the Royal Commission's statement that there is "no case of through running" between "extra London" and the administrative County of London, it may be added that in I904 the combined municipalities of Great Britain, under the leadership of Manchester and Glasgow, defeated the 
efforts of the combined tramway companies to get Parliament to establish the principle of granting "compulsory running powers" in case two adjoining tramway systems are unable amicably to agree upon running powers. The Tyneside Tramways and Tramroads Co. Bill, establishing this principle of compulsory powers, was - passed unanimously by the Committee of the House of Lords, also unanimously by the Committee of the House of Commons; in the House of Commons it was supported by Mr. Bonar Law, Parliamentary Secretary to the Board of Trade, but it was rejected in the House of Commons by 178 votes against $142 . *$

In I90I, the city of London and the twentyeight Metropolitan Boroughs, whose area is II 7 square miles, had 4,557,000 inhabitants, of whom Overcrowding 726,000 , or 16 per cent, lived in the Perpetuated overcrowded condition of more than two people in one room. The six Metropolitan Boroughs of Bethnal Green, Finsbury, Holborn, Shoreditch, Stepney, and St. Pancras had 943,000 inhabitants, of whom 280,000 , or 30 per cent, lived in an overcrowded condition. In eight Boroughs the overcrowded population was less than ro per cent of the total; in nine Boroughs it ranged from Io to 15 per cent; in three Boroughs it ranged from I6 to 20 per cent; in three it ranged from $2 \mathrm{I}$ per

* The Municipal Journal, April I5 and 22, June 10, I7, and 24, July 8 and 29, August 5, 1904, and February 10, 1905. 
cent to 24 per cent; and in five it ranged from 25 per cent to 35 per cent.*

The Report of the Royal Commission on the Means of Locomotion and Transport in London says that the price of land "a few miles out is still sufficiently low" to admit of the building of houses for the working classes, and the renting of such houses "at rents which the tenants can afford to pay ... if means are provided to enable workmen to get in and out of London quickly and cheaply." It adds "that a large proportion of workers in the overcrowded parts of London do not need to live near their work," and "that where facilities for locomotion have been afforded, the population does, in fact, take advantage of them to live outside London." By way of illustration, the Royal Commission cites the growth of Walthamstow from $2 \mathrm{I}, 700$ in $188 \mathrm{I}$ to 46,300 in I89I, to 95,100 in 1901 , and to 110,000 in 1904 . In I90I, 15,000 out of 18,600 houses in Walthamstow rented at less than $\$ 80$ a year, indicating that Walthamstow has been built up entirely by the movement of the less well-to-do classes from the congested districts, in consequence of the Great Eastern Railway running frequent cheap "workmen's" trains. The local authorities of Walthamstow themselves refused to aid the movement or to permit private enterprise to aid it by building street railways in

* Census of England and Wales, 190r. General Report, with Appendices, p. 294. 
Walthamstow. Under the leadership of the politicians, the people year after year debated (I) whether Walthamstow should have tramways at all, and (2) if so, whether it should have municipal tramways or company tramways. Finally, in February, 1903, the city obtained a charter for 9.5 miles of tramway; and in April, I904, it began construction.

Edmonton, which adjoins Walthamstow on the northwest, grew from 23,500 in $188 \mathrm{I}$ to 36,400 in $\mathrm{r} 89 \mathrm{r}$, and to $6 \mathrm{I}, 900$ in $\mathrm{I} 90 \mathrm{I}$, through the provision of cheap workmen's trains by the Great Eastern Railway Co. Not until I904 did the County of Middlesex supply Edmonton with an electric tramway. At the close of 1904, Edmonton, Tottenham, Harnsey, and adjoining towns had one mile of street railway track for each 7500 people.

Leyton, which adjoins Walthamstow on the southeast and has recently had a rapid growth to 120,000 inhabitants, in 1904 had less than seven route miles of electric street railway, supplied by the Leyton Urban District Council. The spirit of the Leyton authorities is illustrated in the fact that, in 1884 , Leyton compelled the Lea Bridge, Leyton, and Walthamstow Tramway Co. to defray the main cost of widening a part of the road to be traversed by the tramway company, "an improvement desired and debated by the Local Board of Works long before the tramway had been proposed." In that same year "some extensions in East London, 


\section{MUNICIPAL OWNERSHIP IN GREAT BRITAIN}

proposed in the company's deposited Bill, were abandoned owing to the terms insisted on by the local authorities." *

The Royal Commission says: "Increased modern means of locomotion and transport are much needed, both to facilitate movement within the central area (the administrative County of London), and to facilitate access to and from and within the suburbs for those who work in London and live outside. Electric tramways and railways are necessary for both these purposes; tramways mostly for the former, and railways mostly for the latter, with intercommunication between the two."

As to the building of additional tramways in the Administrative County of London, the report says: "The opinion is widely held that the streets of London are too narrow for tramways on a large scale. No doubt many streets are too narrow. The real question is whether this disadvantage is so widespread as to necessitate the postponement of a great tramway extension until costly operations of (street) widening have been carried through. Certainly some street improvement is necessary in places, from any point of view, . . . but we are persuaded that a great deal can be done in the way of tramway extension, without any great expense of this kind. . . . We recommend: A large extension of tramways in London and the suburbs; that immediate attention

* Clifford's History of Private Bill Legislation, Vol. I, p. I9I. 
be given to providing through communication between the different tramway systems within the Administrative County of London; across the Thames by the Westminster and Blackfriars bridges; and that provision be made for through running inside and outside the Administrative County of London." The Commission also draws attention to the fact that a large part of the present congestion of the streets is due to the absence of street railways. It cites the estimate submitted by Sir Alexander Bruce, Assistant Commissioner of Metropolitan Police, that 60 per cent of the vehicular traffic of London is made up of omnibuses * and hackney carriages. It adds that in Liverpool the electric tramways have driven the omnibuses off the streets; and that an adequate system of tramways would achieve the same result in London.

Similar testimony was given in March, I904, by Mr. E. J. Harper, statistical officer of the London County Council, $\uparrow$ who said: "Much of the congestion in the streets is due to the places at which passengers are set down by the various carrying companies. Omnibus routes generally run right through the central area to a terminus at its far side. Traffic is attracted by the facility thus given for passengers to alight at any part of the central area most convenient to them. But, generally speaking, railway

* Greater London, 1902: Omnibus traffic, 279,467,000; Tramway traffic, $350,180,000$.

$\dagger$ Journal of the Royal Statistical Society, June, I904. 


\section{MUNICIPAL OWNERSHIP IN GREAT BRITAIN}

and tramway termini are situated on the edge of the central area nearest to the districts which they serve. The result is that railway and tramway passengers, for the most part, are not carried as near to their ultimate destinations as they might wish; and consequently the streets are flooded with pedestrians in the neighborhood of these termini in the morning hours. They either make their way on foot to their destinations, or take omnibuses or cabs for that purpose, thus adding to the causes for vehicular congestion." Mr. Harper added that the number of omnibuses passing along the Strand, at Wellington Street, ranged from 328 per hour to 369 ; along Holborn, at Southampton Row, from 239 per hour to 284 ; along Piccadilly, at Wakingham Harse, from 366 per hour to 400 . In these cases the omnibuses constituted from 29.9 per cent to 36.5 per cent of the total number of vehicles.

On the question of increased transportation facilities from the Administrative County of London to the outlying regions, the Royal Commission said that the steam railroad companies were "not generally prepared to construct lines leading to unoccupied districts in expectation of being 'recouped' by the growth of population," and that, therefore, the decentralization of the population would have to be effected by means of electric railways running in subways or in "tubes." It added, however, that "a marked feature in connection with underground 
railways of all classes has been the difficulty experienced in raising the necessary capital. In the first instance, this was no doubt due to the unusual nature of the enterprise, but its continuance to the present time is due to the fact that the (underground) railways that are at present in operation have not given very satisfactory results from a pecuniary point of view. . . . We have said elsewhere in our report that, in our opinion, if undue burdens are not thrown upon railway undertakings, it will not be necessary to give direct assistance to new railways from public sources. But so much importance do we attach to the construction of railways to new residential districts that, if private enterprise will not make such railways, we have no hesitation in recommending that the municipal authorities should be empowered to assist; this course was recommended by the Joint Select Committee of I901,* as already explained in paragraph 53 of this report. The form in which assistance would be given might vary with the circumstances of the case. The municipal credit might be used to raise the capital cheaply, or the municipal authorities might take shares or find a portion of the capital at a low rate of interest, or arrange for a total or partial remission of local rates (taxes); in some cases they could grant space for stations free of charge. . . . If

* Report of the Joint Committee of Igor on London Underground Railways. 
the London County Council gave assistance in the construction of an underground railway, it might be desirable that it should acquire a tract of land for building purposes at the outer extremity of the line, prepare a building plan for it, and let it on lease for building purposes. A portion of the expenditure might be recovered in this way."

Coming at last to the question of the fares to be charged upon the suggested underground railways, the Royal Commission said: "A uniform fare at as low a figure as four cents per passenger journey, applicable over a system as large as the Metropolitan District Railway system (route mileage, 26 miles), would be a great public advantage. With the speeds at which electric trams will be run, the disadvantage of distance is reduced to a minimum, and, if a uniform fare per journey were charged, it would not only tend to spread the population over a wide area, but would also encourage people to go well into the country, where land is cheaper and the surroundings are healthier. We think that every encouragement should be given to the adoption of a uniform fare of four cents per journey, up to the limit which would reasonably be covered for that fare, and for distances beyond that limit, uniform fares, possibly on a zone system basis." In other words, the Royal Commission rejected the principle of graded fares.

In strong contrast to the position taken by the 
Royal Commission - namely, that in the matter of underground electric railways public necessity and Public Necessity convenience demand that the first conversus Municipal sideration be given to devising means Gain

that shall induce private enterprise to build such underground railways - is the position taken by the London County Council. The latter body holds that the needs of the public treasury take precedence over the necessity and convenience of the public. Mr. Charles Harrison, Chairman of the Parliamentary Committee of the London County Council, appeared before the Joint Select Committee of 1892 on the Electric and Cable Railways to present the demand of the London County Council that there be inserted in the charters of all underground railways, clauses authorizing the London County Council to purchase at the end of sixty years on the basis of structural value. If the County Council should fail to exercise the right of purchase at the expiration of sixty years, it was to have the right of purchase at the end of each recurring period of seven years. This latter provision was copied from the Tramways Act, I870. Mr. Harrison said the County Council might find that sixty years had not been sufficient to enable a company to make its underground railway a paying property; and in that case the County Council would desire to leave the property on the hands of the company until such time as it had become a paying 
property. The County Council had no desire to own or operate a non-paying underground railway.

The underground electric railways, or "tubes," are built at a level of 50 to 80 feet below the surface, following air-lines, not the streets, and the entrances and exits are on the private property of the companies. Furthermore, Mr. Harrison himself admitted that the rights of the public authority in the street extended only to the right of user for the purposes of a street, and that that right did not extend 50 to 70 feet below the surface. These facts led Mr. Bolton, a member of the Committee, to ask Mr. Harrison, "Upon what ground of principle do you justify any claim for compensation either in the shape of the right of purchase, or in any other way, for the right to tunnel asked for from Parliament?" Mr. Harrison replied, "We base it on the broad ground that every municipality should be at liberty to acquire all that which is necessary for the municipality, of which locomotion is one, as is evidenced by the tramway system; and that if it is advisable that we should have a remunerative undertaking for the tramway system, this is another subterranean tramway system, and would be subject to the same rule." Mr. Bolton continued, "But in connection with the tramways, the tramway company acquire the exclusive right of a portion of the street." Mr. Harrison replied, "No, they do not, indeed." Mr. Bolton, "Therefore they have the exclusive 
right to a particular user of the street." Mr. Harrison, "I do not at all agree with that; they have no more user than I have. I can drive with my carriage over the rails without (using) the flange wheel." Mr. Bolton, "Was it not in consideration of the rights that were given them over the public streets that Parliament thought it desirable to give the local authority the right to resume at particular periods the full control of the streets?" Mr. Harrison, "I do not think so; of course it is a matter of opinion, but I should have thought that the ground upon which the right of purchase of the tramways was based, was not upon that ground at all, but that locomotion was a matter, as much as light and water, which in a municipal area ought to be carried on by, and be in the hands of a municipal authority." * Thus we find the London County Council, in 1892 , taking toward the new industry, "tube" railways, precisely the attitude which the British municipalities had taken in 1870 toward the new industry of horse street railways. In both cases the attitude was, without qualification, the simple one of proposing to use the public authority's power to regulate the use of the streets for the purpose of putting money into the public treasury. There was no desire to promote the public convenience by aiding and facilitating the establishment of a new means of locomotion.

* Report from Joint Select Committee of House of Lords and House of Commons on the Electric and Cable Railways (Metropolis), I892; q. 416, 629 to 665 . 


\section{CHAPTER XI}

THE MUNICIPAL PURCHASES OF COMPANY GAS PLANTS

IN order to understand the conditions under which Parliament enacted the disastrous Electric Lighting Act, I882, which Act will be discussed in the next chapter, it is necessary to describe briefly the purchases of company gas plants made by the British municipalities in 1869 to 1878 .

With the rapid growth of the British cities which set in with the beginning of the second half of the last century, the gas lighting industry passed from the speculative and non-paying state to the state of an established industry attended with little risk and yielding a fair profit. Thereupon the British cities and towns, which, with few exceptions, had let the industry severely alone while it was in the speculative state, $*$ began to hunger and thirst after the profits to be made in it. For example, in 1874 , Mr. Joseph Chamberlain, Mayor of Birmingham, used

* The Journal of Gas Lighting, Water Supply, and Sanitary Improvement, July 9, 1878 . Manchester is the only instance of a local authority initiating a gas plant.

Manchester established a public gas plant in 1843 . The first charter to a gas light company was granted in 1810. 
these words before a Select Committee of the House of Commons: "It is with the object of diminishing the direct taxation of Birmingham that we are promoting this Bill" (for the purchase of the gas plant). In the Birmingham Town Council, Mr. Chamberlain expressed the hope that the city would make a

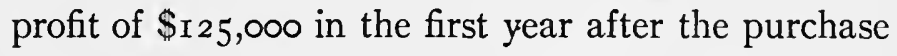
of the gas plant, and larger profits in subsequent years.* He added: "When the purchase of the water works comes before you, it will be a question concerning the health of the town; the acquisition of the gas works concerns the profits of the town and its financial resources. ... Both are matters of absolute public necessity." $\dagger$

Again, the following article appeared in the Hereford Journal in June, I877. "Happy Hereford! - We Herfordians must congratulate ourselves on our latest bereavement. The city rate (tax) has expired. It is dead, past, and gone, and will never come to life again. To be still more explicit, let us put it in this way - the citizens of Hereford will never have another city rate (tax) to pay. They have paid the very last copper that will be asked of them. Henceforth the water works, the gas works, and the markets will provide all the necessary funds to meet the expenditure chargeable on the city rate -

* Report from the Joint Select Committee on Municipal Trading, I900; Mr. E. O. Smith; Town Clerk of Birmingham since 188r, q. r894.

$\dagger$ N. M. Morris: Joseph Chamberlain, The Man and the Statesman, p. II2. 
an expenditure which, before now, has had to be met by a rate of 3 shillings and 6 pence in the pound." * In I904 Hereford was a city of 22,000 inhabitants; it had no street railways, and it had obtained the electric light as late as December, 1899. In the period from 1844 to 1867 , the cities bought out I 3 gas companies. In the ten years 1869 to 1878 , they bought out 68 companies, purchasing respectively Io plants and 17 plants in the two years 1877 and 1878 . In 1879 , they bought only 2 plants; and in the thirteen years from I 880 to I 892 , they bought only I 5 plants. In 1892 the cities resumed the policy of acquiring gas plants, purchasing 67 plants in the eleven years from 1893 to I903. At the close of 1903,280 municipalities in the United Kingdom owned gas plants. Of that number, 169 , or 60 per cent, had purchased their plants fully established on a paying basis and equipped with trained staffs, and only 40 per cent had incurred the trouble and risk incidental to the development of a paying business and the organization of a trained staff. $\dagger$

The suspension of purchases by the municipalities in the period from 1879 to 1892 was due to the fear of the electric light as a competitor of the gas light. In the earlier years of that period the "scare" was serious, the shares of some gas companies declining as much as 30 per cent. In November,

* The Journal of Gas Lighting, Water Supply, and Sanitary Improvement, July 3, I 877 .

†"The Gas World" Year Book, I904. 
I 878 , the citizens of Hereford became so alarmed that they held a public meeting and protested against the city proceeding with the erection of the new gas works for the next three months.*

Nominally the sales of plant made by the companies were voluntary, but as a matter of fact they were not infrequently compulsory. There are two kinds Sales of Plants by of gas companies, statutory and nonCompanies usu- statutory. The former are authorally compulsory ized by Special Acts; the latter have no parliamentary authority, but operate "under the freedom of trade that exists at common law with regard to the supply of gas as with regard to the supply of other things." $\dagger$ As to statutory gas companies, it is the general policy of Parliament to refuse compulsory sale. + But it is possible for the local authorities to worry companies into selling out. Before a Select Committee of the House of Lords, in I886, Sir F. J. Bramwell stated that municipalities had all kinds of ways of forcing companies to sell, by opposing the companies' applications before Parliament for permission to increase their capital in order to expand their plants, to supply gas-motors, and to do many other things dictated by business

* The Journal of Gas Lighting, Water Supply, and Sanitary Improvements, July 17 and December 25,1877 ; October 29 and November I 2,1878 .

† "The Gas World" Year Book, 1904: "The Law of Gas Supply," by J. Duncan, of the Middle Temple, Barrister-at-Law.

$\ddagger$ Report from the Joint Select Committee on Municipal Trading, 1900; Sir Courtenay Boyle, Permanent Secretary to Board of Trade, p. $35^{2}$. 
enterprise. Sir F. J. Bramwell, by virtue of his position as one of the most eminent mechanical engineers of Great Britain, had had very large experience as arbitrator and as expert witness in cases of the sale of gas works and water works to local authorities. He was, moreover, a man ready to make pecuniary sacrifices for the sake of his convictions, as he had never consented to appear as a witness for a local authority asking Parliament for power of compulsory purchase.*

Before the same committee, Mr. S. G. Johnson, Town Clerk of Nottingham, admitted that the city of Nottingham had finally worried the gas company into selling out, by opposing every application the company made for permission to extend its mains into the outlying suburbs. The Town Clerk said the company's standard dividend, under the sliding scale of prices, had been 5.5 per cent, and "whenever they could pay more than 5.5 per cent dividend, rather than reduce the price of gas in the city they built mains to places outside the city for which they could not get more than I.5 per cent profit, so they brought the dividend down to 5.5 per cent." At the time of the sale to the city the company was supplying gas to an area of over 100 square miles outside of Nottingham. In 1898 the Town Clerk of Nottingham testified that the city was making a "large

* Report of Lords Committee on the Electric Light Act, 1882, Amendment Bills, 1886; Sir F. J. Bramwell, q. 448, 404, 405, and 580. 
profit" from the sale of gas, but that it had built no further mains into the outlying districts.*

In 1899 the Bristol Gas Co. asked Parliament for enlarged powers, in order that it might lay pipes for the purpose of conveying oil and tar, by-products of the gas industry; and also hire out dynamos to be operated by gas-engines. Upon the opposition of the city of Bristol, Parliament denied the request. Again, the company was bound by its charter not to charge the city a higher price for gas for street lamps than the lowest rate paid for the time being by any consumer. When this contract was made gas was used only for lighting. The company now asked Parliament for permission to make special rates on gas used for purposes other than lighting, without being obliged to extend those rates to gas for street lamps. Upon the request of the city, Parliament refused the desired permission. At this time the city was furnishing electric current for power at 3 cents per unit, while it was charging for current for lighting from 4.66 cents to Io cents per unit. $\dagger$

The non-statutory gas companies are not restricted by the provisions of the Gas Works Clauses Acts, 1897 and $187 \mathrm{I}$, which are inserted in all Private

* Report of Lords Committee on the Electric Light Act, I882, Amendment Bills, I886; q. ${ }_{5} 67$ to $\mathrm{I}_{590}$; and Report of Joint Committee on Electricity Generating Stations and Supply, I898; q. I384, I458, and I 459 .

† The Journal of Gas Lighting, IVater Supply, and Sanitary Improvements, March 28, and June 27, I899; and April I7, I900. 


\section{MUNICIPAL OWNERSHIP IN GREAT BRITAIN}

Acts, and compel supply, fix the standard of illuminating power, pressure, and purity, and limit the profit to be divided among the undertakers. For that reason the status of the non-statutory gas company is adapted to small towns in which the outlook for gas undertakings is not promising, and capitalists have to be tempted into the field through the removal of every governmental regulation and restriction. But the non-statutory companies are liable to be wiped out through Parliament creating in their areas statutory companies, which, by implication, obtain a monopoly to supply gas in the areas for which they are authorized. The towns are very likely to apply to Parliament for a charter as soon as the statutory companies have passed through the years of uncertainty and loss, and have established themselves as profitable ventures. Generally speaking, Parliament in such cases will give the charter to the company and not to the local authority, if the local authority cannot prove past mismanagement or bad supply of gas on the part of the non-statutory company. "But in certain cases, where very strong local feeling exists, (Parliamentary) * Committees have brought some pressure upon the company to induce them to agree to sell upon very favorable terms." Then again, the companies often are disinclined to incur the heavy expense of proving before

* Report from the Joint Select Committee on Municipal Trading, I900; p. 352, Sir Courtenay Boyle, Permanent Secretary to Board of Trade. 
a Parliamentary Committee that their past management has been satisfactory; they prefer to let the application of the local authority go unopposed, in consideration of the purchase of their plant by the local authority.

Before the Joint Select Committee on Municipal Trading, in 1900, Mr. E. C. Leigh, since 1883 Counsel to the Speaker and Chairman of Committees of the House of Commons, testified as follows upon the subject of the purchases of gas plants by the local authorities. "What my personal opinion is may not be worth much; but perhaps you will stop me if you think I am going further than I ought. At the same time, I rather deprecate the practice of municipalities acquiring compulsorily both water and gas companies against their will and without their consent, and this practice has increased to an enormous extent during the last few years. I can remember when I was first at the Parliamentary Bar, and it goes back, I am sorry to say, to 1872 , the only case of compulsory acquisition had been the Stockton and Middlesborough case. Then Birmingham came for gas and water (in 1874). I think, if I remember rightly, I was Junior Counsel in both those (Birmingham) Bills. ... Eventually both the water company and the gas company were acquired by agreement; I forget the number of years' purchase, but upon very liberal terms. Then I cannot 
remember a case for a great many years where a single gas company or water company have been acquired when they objected to it, and when the Committee found that the identical gas or water company had been doing their duty and satisfying the needs of the town or district. Then some few years ago that seems to have altered. There is no question about it that in the last few years compulsory purchase has been granted in several cases, or a company has been driven to find that they had far better agree to be bought up on fairly liberal terms than to fight the thing in Parliament ... and I should like to add that that is very often the case with small municipalities or local boards. The larger public authorities, I am bound to say, can always show a very much better case (for compulsory purchase) than the smaller ones. I think Mr. Gray (Counsel to the Chairman of Committees in the House of Lords) made the same remark in his evidence. It has been too much a habit of late years for small bodies, who have no right to come for these powers, to buy up water and gas, to come and get powers from Parliament. We have had them in the case of unopposed Bills. As a matter of fact, the result is this: Taking gas, local authorities, to the number of 250 , already hold the supply of gas in Great Britain, and in practically the whole of those cases the gas undertaking has been originally 
founded by a company, and subsequently purchased by the municipality. In fact, one may say broadly, municipalities never invented or initiated anything, either with regard to tramways or gas or electric lighting, and yet when a company has become flourishing, they have been rather forced in a corner to sell their undertaking. ... Then I think I may go a little further and say I know of no case in which a municipal body has sought to acquire a gas undertaking which was not in a flourishing condition. They have not come in for the purpose of helping the (consumers in) municipality when a gas undertaking is being badly carried on, but they have pounced upon gas companies when they are paying their full dividend. ... Then, I may add, in a great many cases efforts have been made to acquire gas undertakings which, having struggled through a long period of unprofitable working, are now on the eve of success. I know of no less than four cases in the last two Sessions of Parliament, three of which were thrown out by Parliament, and the other was passed where, just as they were turning the corner, the (municipal) corporation had pounced upon them. ... In my experience, the local authorities are rather in the habit of catching hold of flourishing companies; I do not see that they try to get the companies who are in deep water out of their deep water into shallow water.... 
I am talking of the habit that has grown up in late years - I am not talking of great towns like Leeds and Birmingham, but very small local Boards which come for the compulsory purchase of gas companies which are just beginning to feel their way." *

The extent to which the local authorities have confined themselves to the purchase of the more remunerative gas undertakings is indicated by the Municipalities following testimony from Sir Courtprofit from Initia- enay Boyle, Permanent Secretary tion of Companies to the Board of Trade from 1893 to I90I. "The average receipts per thousand cubic feet of gas sold (in I898-99) was in the case of local authorities, 72.8 cents, as compared with 84.4 cents received by companies. This would indicate that generally the price charged to consumers was higher in the case of companies than local authorities, but in making such a comparison it should be borne in mind that the districts served by local authorities are usually the most populous, and therefore, the most remunerative. On the whole, the returns do not suggest that in like circumstances there is any great balance of advantage to the consumer, as regards the price charged, in being supplied by a local authority instead of by a company." $\dagger$

The price paid by the municipalities for gas

* Report from the Joint Select Committee on Municipal Trading, 1900; q. 619 to 623 , and 672 to 676 .

$\dagger$ Ibid., 1900; p. 35 I. 
plants always is "the fair market value," which includes an allowance for future growth of profits, if, at the time of the sale there is promise of such future growth. "The Gas World" Year Book, I904, gives the price paid for each $\$ 100$ invested for 77 out of $\mathrm{I} 60$ cases of sale to the $\mathrm{mu}$ nicipalities in the period from $\mathrm{I} 844$ to 1903 . In $5^{2}$ per cent of the cases, this price ranged from 200 to 272 , and in 35 per cent of the cases it ranged from I50 to 193. The premiums paid were high absolutely, but they were relatively reasonable, and they were justified by subsequent experience, largely through the growth of the British cities in population since $185^{\circ}$. In the year $1898-99$, all but 48 of the 222 municipal gas plants of the United Kingdom paid the interest and sinking fund payments properly chargeable against them. 


\section{CHAPTER XII}

THE ELECTRIC LIGHTING ACT, I 882

IN I88 $\mathrm{I}$, the incandescent electric lamp was brought to the "commercial stage," and there were opened in the United States eight central clectric stations. In the following year there were opened thirty such stations. In that same year, I882, the British Edison Co. installed a small plant in London and operated about one thousand incandescent lamps in the hotels, restaurants, and shops on the Holborn Viaduct. The company had no statutory powers, but counted on obtaining them in the near future. Similarly, a company in the little town of Godalming supplied eight or ten houses with incandescent electric lights, besides supplying six arc lights and a few incandescent lights for street lighting. Many private plants for arc iighting, as well as for incandescent lighting, were established in the same year in industrial and mercantile establishments and places of amusement.*

* Report of Committee on the Electric Lighting Bill, 1882 ; 2429; and ieport of Committee on Electric Lighting Provisional Orders Bills, 1883 ; q. 460. 
In 1882 the speculation in London in the shares of the several electric companies representing the Board of Trade claims of the rival inventors reached misjudges Situa- enormous proportions, the shares of tion the Brush Co., upon which $\$ 20$ had been paid in, at one time selling at \$140** The Board of Trade completely misjudged the situation, as it had misjudged the tramway situation in 1870 and in 1878 . It concluded that the electric lighting industry was going to be enormously profitable, and that its sole care must be to see to it that the local authorities obtained power to acquire on "tramway terms" whatever electric light plants should come to be established. Accordingly, the Board of Trade drew up, and its President, Mr. Joseph Chamberlain, introduced into Parliament a Bill authorizing the granting of charters subject to the proviso that the local authorities should have the right to purchase at replacement value, at the expiration of seven years. Before the Select Committee to which the Bill was referred, Mr. T. H. Farrer, Permanent Secretary of the Board of Trade from 1867 to 1886 , defended that provision with the statement that the Tramways Act, I870, "in no way interfered with the investment of capital" — a statement with

* Hansard's Parliamentary Debates, July I5, I882, p. 57 r, Mr. W. Fowler; and Report of Lords Committee on the Electric Light Act, 1882, Amendment Bills, I886, q. $85^{2}$; Mr. J. S. Forbes, Chairman of Edison Swan Electric Light Co. 


\section{MUNICIPAL OWNERSHIP IN GREAT BRITAIN}

which every banker in the city would have taken issue.* In the following year, ı883, Mr. Farrer supported the provision for compulsory sale with the argument that the Board of Trade was not competent to ascertain the price of supplying gas or electric current, and that, therefore, it was not competent to protect the consumer by the exercise of the power to fix the price of gas or electric current. Under the circumstances, there was no alternative to the policy of public ownership. But, he added, public ownership could be established only through the utilization of private enterprise. He said the Board of Trade "felt that whilst local authorities represented the ratepayers, they were in many cases inert bodies not willing to adopt new things, in some cases perhaps prejudiced by being the owners of gas undertakings, and therefore not by any means certain in all cases to give the ratepayers the benefit of this new invention. . . It is unnecessary for me to enlarge upon the question of private capital versus public bodies. I think all experience in this country shows that whilst capital is extremely active and will always support a new invention, if there is a prospect of success, there is no such active motive power upon the part of governing bodies; they take up a thing when it is done, but they are not persons generally

* Report of Committee on the Electric Lighting Bill, 1882; q. 42, $5: 240,24 \mathrm{I}$, and 227 . 
willing, nor perhaps are they the best persons, to take up a new invention." *

Before the Select Committee of I882, Sir John Lubbock, head of the eminent banking house of Robarts, Lubbock \& Co., and Chairman of the British Edison Co., argued that capital would not embark in electric lighting on the condition of merely getting the actual value of the plant upon the expiry of the charter. $\mathrm{He}$ asked for twenty-one years, with compulsory sale, on the basis of fair market value. $†$ To the Government itself Sir John Lubbock stated that the British Edison Co. would withdraw from the field if compulsory sale at structural value should be established. The Government replied: "Well, other companies are quite ready to provide the capital; and if the Edison Co. does not see its way so to do, we are very sorry." $\ddagger$ The Select Committee itself reported in favor of fifteen years, with compulsory sale at standard value, the Chairman of the Swan Co., as well as the Chairman of the Hammond Co., having accepted those terms under protest, fearing that the alternative would be the failure of the House of Commons to enact any measure whatever. $\S$

* Report of Committee on Electric Lighting Provisional Orders Bill, I 883 ; q. 2 and 7.

$\uparrow$ Report of Committee on the Electric Lighting Bill, 1882; q. 2862 and 2863 .

$\ddagger$ Report of Lords Committee on the Electric Lighting Act, I882, Amendment Bills, 1886; q. 1081, Sir John Lubbock.

$\S$ Hansard's Parliamentary Debates, August 14, I882, p. I782, Sir John Lubbock; and July 15, I882, Mr. Story-Maskelyne; Report of Committee on the Electric Lighting Bill, I882; q. 227. 
In May, I882, The Economist (London), the leading financial newspaper in the world, wrote: "The electric light is very probably a great invention, and, for the sake of argument, let us take it for granted that its future development will be vast. But this, unhappily, cannot be argued as a reason why the pioneer companies should be prosperous. The history of our company manias has always proved the contrary." The newspaper cited the case of the railway, the submarine telegraph, the asphalt pavement, and the early sewage schemes, adding that the list might be extended to any length.

In the House of Commons, Mr. Joseph Chamberlain, President of the Board of Trade and Chairman of the Select Committee to whom the Bill had been referred, said: "The Select Committee were guided in their conclusions by this line of reasoning - that it was their bounden duty to accept the shortest term which, at the same time, would leave room for the development of these experiments, and to go beyond that they considered would be to prejudice the rights of the public for the benefit of private speculators. The objects of the Bill were twofold - first, that no obstacle should be placed in the way of the development of the electric light; but, in the second place, that the interest of the public, as a whole, should be protected, and that a new monopoly should not be 
set up as in the case of the gas companies, the water companies, and the telegraph companies, only to be purchased at a ruinous price. The question was, whether the figure adopted (fifteen years) was the right one, and, as to that, every member could form his own judgment, but he had it ${ }^{\circ}$ on the authorities of the companies concerned that they were perfectly satisfied with the arrangement come to by the Committee; the only company that was dissatisfied was the Edison Light Co. . . . But the other companies declared that, in their opinion, the term was sufficient to justify the experiment they desire to make; and seeing what had been done without any parliamentary powers at all, the Committee must agree it was sufficient. So far as experiments were concerned, the companies could do without any Act of Parliament; but what they asked was the power to enter upon streets and to break up roads to lay their wires, and certainly a monopoly right * of that kind should be under strict limitations, and be confined to as short a period as would amply provide for the due development of the experiment." Mr. Chamberlain added that "in his opinion, gas companies or corporations (municipalities), having powers to supply gas, had obtained no right whatever to be protected by Parliament against the introduction of any new light." But he fore-

* The Act of 1882 granted no monopoly whatever. 
saw the possibility of "great vested interests" defeating the establishment of the new industry by opposing, before Parliamentary Committees, the Bills asking Parliament to confirm the Provisional Orders issued by the Board of Trade. Such opposition might make the cost of obtaining a Provisional Order prohibitive. Therefore, he provided that the Board of Trade should have power to issue licenses which should run seven years and need not be confirmed by Parliament. He said that if they proceeded exclusively by way of Provisional Orders, "the probability was that such Orders might, at any rate, be opposed by great vested interests, which were to a certain extent hostile to the new illuminant; and the venders and consumers, who were desirous of having this new light, and the inventors who were desirous of introducing it, would be at such a great disadvantage in consequence of the enormous cost of obtaining powers that they would materially interfere with the progress of the new science."*

Mr. Slagg, M.P. for Manchester, said: "His Honorable Friend who had just spoken had comopposition to plained of the way in which elecLong Franchises tric lighting companies were to be treated under the Bill, being tied down by the compulsory sale of their undertakings. But he took this view very strongly in regard to the * Hansard's Parliamentary Debates, July $15,1882$. 
establishment of electric light companies in districts where gas was at present supplied by local authorities; who must necessarily be the best judges of what was good in such matters as lighting. He did not deem it to the public interest necessarily that outside companies should be invited to come in and make an exploitation ground for an area which had already been supplied (with gas) on the most favorable and economical terms by existing local authorities. Why should they encourage any outside body of people to come and abstract a profit already made by a local body (and) applied to local purposes in the matter of rates. On that ground, he considered that no encouragement was due from that House of the Legislature in getting private persons to invade towns where corporations (municipalities) had already well discharged their duty to satisfaction. He would take the case of his own corporation in Manchester. They had a very efficient gas supply, and supplied not only their own local area, but also twenty-one outside townships, at a very much lower rate than they could possibly supply themselves. What would happen under the aspirations of his Honorable Friend? He wished to give encouragement and protection for the Board of Trade to allow companies entirely outside the sympathy, accommodation, and interest of those bodies (municipalities) to obtain and 


\section{MUNICIPAL OWNERSHIP IN GREAT BRITAIN}

take away the profits which they had been accustomed to enjoy to the very great advantage of their community. He did not see that electric lighting companies had any logical ground for assuming such a position. .. I It would be rather too hard to ask those communities whose territory had been invaded, and whose money had been extracted to pay huge dividends, to compensate the companies (at the expiry of fifteen years) for the business they had planted there.... He did not see why outsiders should be let in to make happy hunting grounds of the corporation area. Fifteen years he thought quite sufficient, the companies were satisfied with that term, and he should certainly vote for keeping that term." *

In the House of Lords, the Lord Chancellor said: "There was no wish to discourage enterprise in any way; but at the same time, they were anxious not to repeat the fatal errors which were made in the case of the gas and water companies. It would, no doubt, be satisfactory to noble Lords to know that not only had all the companies expressed themselves as satisfied with the arrangements proposed in the Bill, but the Board of Trade had information to the effect that one company, when the Bill passed, would make as many as 95 applications" for Provisional Orders. $\dagger$

* Hansard's Parliamentary Debates, July I5, r882, p. 569 and 6r5.

$\dagger$ Ibid., August 3, 1882, p. 576. 
Lord Sudely said the main opposition to the Bill came from the gas companies, who objected to the clause authorizing the issue of licenses.*

The Marquess of Salisbury said: "He thought the terms offered the electric companies were not quite fair. As the matter stood, those companies would have to carry on their undertakings with the full consciousness that all the risks would be theirs, and all the profits would go to the public - that was to say, if they failed, no one would come forward to help them, and if they succeeded, the municipality would step in and sweep up all the benefits. The noble Earl opposite had said, in defence of the policy of the Bill, that they should be very cautious on behalf of the public. For his part, he apprehended that their first duty was to consult the interests of the public, not by thinking merely of the profits which the municipality might or might not make some fifteen years hence, but by thinking how some good would come to the consumers of an article which would benefit them enormously. It was the public which would suffer if these companies were not allowed to come into the field, and if this new instrument of power, which science had discovered, were compelled to remain useless and unfruitful for several years. $\dagger$ The House of Lords amended the Bill, author-

* Hansard's Parliamentary Debates, August 3, 1882, p. 570.

† Ibid., August 3, 1882, p. 575 . 
izing the Board of Trade to extend the life of a charter to not to exceed twenty-one years. The House of Commons accepted the amendment. Mr. Chamberlain said: "Fifteen years was a compromise, and at the time when the question was last discussed in that House, he was of opinion that it was a fair compromise; but, since then, further information had been brought before him which had certainly made a difference in his opinion, and which he thought might alter that of his Honorable Friend. At the time when the matter was discussed before the Select Committee, it was certainly the opinion of the Committee that, in the present experimental stage of electric lighting, there would not be any considerable expenditure of capital; and if it was proposed to try, in an experimental way, the lighting of a strect, or of a few houses, or a small district, a monopoly* of fifteen years would be quite sufficient. But already, in the few months during which this matter had been under discussion, very great progress had been made with electric lighting, and it now seemed very probable that large installations would be made, in some cases involving hundreds of thousands of pounds sterling, and it did not seem to him that fifteen years would, in all cases, be sufficient to justify such an outlay, and that if the

* The Act of 1882 conferred no monopoly whatever. 
companies were strictly confined to that short time, they would not be induced to spend their capital, and give that development to electric lighting which was desired." $\mathrm{He}$ added that twenty-one years was the maximum, that the local authorities would be free to make any arrangements with companies for periods less than twenty-one years.*

In 1883 , the electric light companies took out fifty-five charters; in 1884 , four charters; in 1885 , none; in 1886 , one charter; and in 1887 and 1888 , Development they took out none. At the close of checked I888, all but one of the foregoing charters had been revoked by the Board of Trade for non-use. The solitary charter then in existence was held by the Chelsea Electricity Supply Co. for the area of Chelsea, a part of Metropolitan London. The Chelsea company did not begin to supply current until September, I889.

At the close of 1888 , there were in operation in the United Kingdom twelve central electric stations which sold current to a limited number of customers. $\dagger$ Two of those plants operated under seven

* Hansard's Parliamentary Debates, August I4, I882, p. I779.

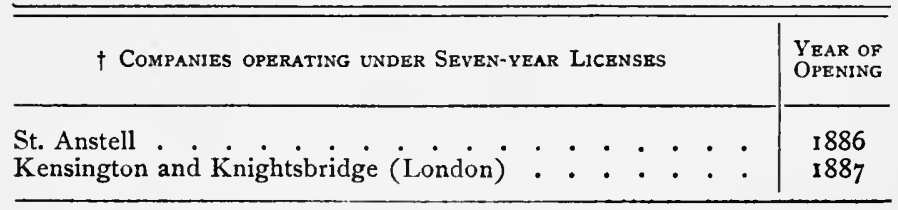


years' licenses, on terms which precluded "such expenditure of capital as is necessary for a successful commercial undertaking on a large scale," to employ the words of Mr. T. H. Farrer, Permanent Secretary of the Board of Trade.* The ten remaining plants were operated under the so-called "marauding" system. $t$ The proprietors of those plants stretched wires from housetop to housetop, when they could obtain the consent of the owner, and crossed the streets above the so-called "area of ordinary user." They were at the mercy of the owners of the houses who gave their consent only for short periods, generally a year or less. They were also liable to indictment under the charge

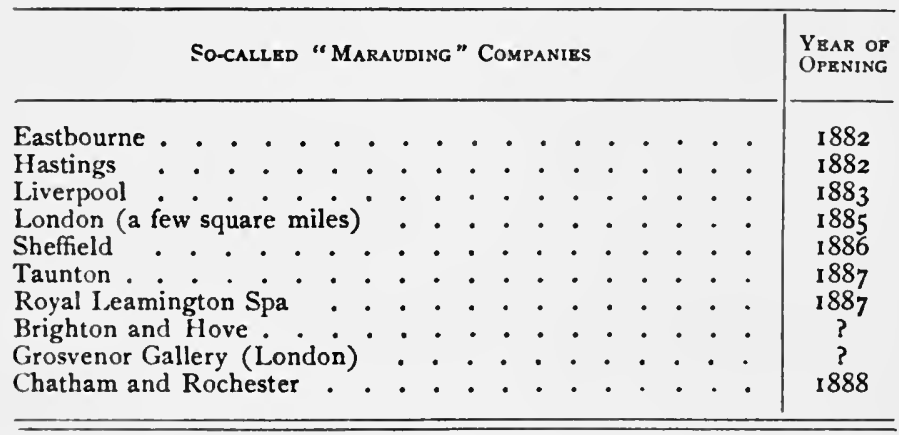

This table is based upon data obtained from: Report by the Board of Trade respecting the applications to and Proceedings of the Board of Trade under the Electric Lighting.Acts, 1892 to 1902, during the year I903-4;. Gucke's Manual of Electrical Undertakings, current issues; and testimony given before various Parliamentary Select Committees.

* Report of Committee on Electric Lighting, Provisional Orders Bills, $1883 ;$ q. 117 .

$\dagger$ Report of Lords Committee on the Electric Light Act, 1882, Amendment Bills, 1886; q.1911; Mr. W. H. Preece, Electrician to the Post Office. 
of being a common nuisance.* Under the circumstances the "marauding" companies were precluded from giving any satisfactory or general service. One of the most important of them, that at Brighton, had only I 2 or 15 miles of wire. The significance of the "marauding" companies is the same as that of the tramway companies which built tramways in the latter sixties without any Parliamentary authority-that is, without legal power to break up the streets. Both of those classes of enterprise show the tenacity of the British capitalists, the eagerness of these men to take up new inventions, and the length they were prepared to go in overcoming obstacles.

In the United States there were opened: in I88I, 8 central electric stations supplying current to the public; in 1882,30 central electric stations; in 1883,27 ; in 1884,47 ; in 1885,55 ; in 1886 , 100 ; in 1887 , 147 ; and in 1888,160 ; making a grand total of 574 central electric stations in operation at the close of r888. $\dagger$ On the basis

* Report of Lords Committee on the Electric Light Act, 1882, Amendment Bills, I886; q. 2074; Mr. Robert Hunter, Solicitor to the Post Office. "When the Electric Lighting Act, I882, was passed it was deemed that no electric works could be constructed without statutory powers of breaking up streets and carrying wires from point to point. But since that Act was passed, it has been decided in the case of Wandsworth District Board $v$. The United Telephone Co. that if wires were placed at a sufficient height above the street to be out of what was called the ordinary area of user, the local authority have no power by virtue of their possessory interest in the soil of the street to interfere with the wires. It did not decide the question whether if it could be shown that those wires were a nuisance, the local authorities might take proceedings against them or anybody else."

$\dagger$ United States Census Bulletin, No. 5, I903. 
of assigning one central electric light station to one city or town, there were, in 1888 , enough central electric stations to give one station to each city and town with 8000 or more inhabitants. That assignment left over 57 stations to be distributed among 75 towns, with a population of 7000 and less than 8000 .

The cities of Germany, in part under the influence of the example of British legislation, also adopted the policy of bartering in electric lighting franchises. The result was that German private enterprise was excluded from the field of public electric lighting while that industry was in the formative period. The conditions enacted by the German cities were so onerous that capitalists could not accept them so long as new inventions in electrical machinery were liable to be made any day and thus render obsolete the existing machinery. The result was that at the close of I888, there were in operation in Germany only fifteen central electric stations, supplying current to the general public. Not until 1894 did the German capitalists feel justified in taking up electric lighting on any considerable scale. * The work of es-

* Elektrotechnische Zeitschrift; January I2, I905.

Central electric stations opened :-

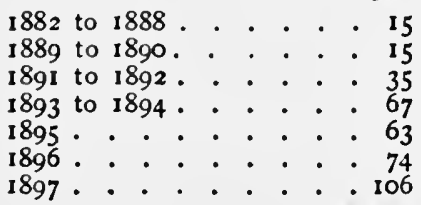

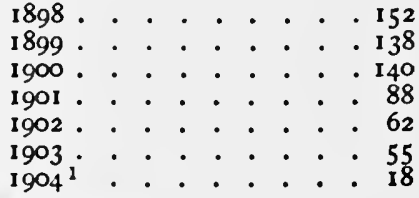


tablishing the industry and bringing it to the point where capital could afford to accept the burdensome terms made by the German cities was done by American capitalists, who operated under the fostering stimulus of liberal charters. 


\section{CHAPTER XIII}

BACK TO THE DARK AGES

IN 1885 the Gladstone Ministry, which, under the leadership of Mr. Joseph Chamberlain as President Attemptsto Liber- of the Board of Trade, had been alize the Electric responsible for the Electric Lighting Lighting Act .Act, I882, was replaced by the Salisbury Ministry. In 1886, Lord Houghton, as the representative of the Salisbury Government, introduced in the House of Lords a Bill proposing to extend the length of electric lighting charters to thirty years, and to forty-two years in any case in which the local authority concerned should give its assent. At the same time, the Earl of Camperdown introduced in the House of Lords a Bill proposing forty-two years as the life of charters, and providing for compulsory sale on the basis of allowance for goodwill - that is, present and prospective profits. Lord Rayleigh, an eminent scientist,* introduced a third Bill

* Rayleigh, 3d Baron, John William Strutt, D.C.L., LL.D., F.R.S., Scientific Adviser to Trinity House since 1896; Professor of Experimental Physics, Cambridge, 1879 to $188_{4}$; Secretary to Royal Society, I887 to I 896; Professor of Natural Philosophy, Royal Institution, since 1887 . Who's Who, 1905. 
which proposed to protect the investor by abolishing compulsory sale, and proposed to protect the consumer by establishing a sliding scale of price and dividend, under which, starting from a given point of maximum price and dividend, a company would be allowed to add a quarter of one per cent to its dividend every time that it reduced its charge for current by a stated amount. Lord Rayleigh's Bill proposed also that whenever a company should issue new shares for the purpose of enlarging its plant, it should sell them at public auction, and the premiums realized, if any, should be invested in the plant, but should not be allowed to draw dividends or interest. Lord Rayleigh's Bill proposed to put the electric light companies on the same footing as the gas companies - in order that the electric light might be enabled to compete with the gas light.

The sliding scale of price and dividend, together with the auction clause for new issues of stock, had been inserted in all Acts of Parliament affecting gas companies passed since $1877 *$ And in $1883, \mathrm{Mr}$. T. H. Farrer, Permanent Secretary of the Board of Trade from $\mathrm{I} 867$ to $\mathrm{I} 886$, had stated that they "seemed to have worked well," and that they had "to some extent modified, if not put an end to the abuses" from which the consumers of gas had suffered. Those statements, Sir Robert Giffen, the

* The Journal of Gas Lighting, Water Supply, and Sanitary Improvements, April 17,1877 . The clauses in question were inserted in only 45 of the 360 Acts affecting gas companies enacted in $185^{6}$ to 1876 . 
eminent statistician,* allowed to stand unmodified in the 1902 edition of Mr. Farrer's book on The State in Its Relation to Trade, for which he wrote a supplementary chapter.

The sliding scale and auction clauses were adopted rather late in the history of gas lighting. Had they been adopted earlier, they would have been still more effective in protecting the consumer. In I882, the year preceding the first issue of Mr. Farrer's book, the capital that had been raised under the auction clauses was $\$ 10,330, \infty 00$, and the premiums realized thereon had aggregated $\$ 4,788,000$. In I 900 the respective figures were: $\$ 55,152,000$ and $\$ 24,336,000$. The latter figure was 8.9 per cent of the total share capital of the gas companies, and $7 \cdot 3$ per cent of the total share and debenture capital.

The three Bills introduced in the House of Lords in 1886 were referred to a Select Committee of the House of Lords, which heard evidence from leading A Study of the financiers, manufacturers of elecBureaucratic trical machinery, electrical engineers, Mind scientists, the town clerks of leading cities, the representatives of the Association of Municipal Corporations, Sir H. G. Calcraft, Permanent Secretary of the Board of Trade from

* Giffen, Sir Robert, K.C.B., sub-editor of Globe, 1862 to I866; assistant editor of Economist, 1866 to 1876 ; Chief of Statistical Department of Board of Trade, 1876 to 1882 ; Assistant Secretary Board of Trade, and afterward Controller-General of Commercial, Labor and Statistical Departments, 1882 to 1897 . Who's Who, I905. 
1887 to 1892 , and a number of British town councillors. The evidence of the town clerks gives us an insight into the working of the bureaucratic mind, and, when supplemented by the evidence of the town councillors, provides us with a gauge of the compass of mind of the British town clerks and municipal councillors, that makes us reject once and for all the argument frequently advanced that the experience gained under municipal ownership in Great Britain proves that governmental activity can take the place of private enterprise. The evidence of the Permanent Secretary of the Board of Trade is a fitting climax to the uninterrupted record of incapacity to sympathize with the man of affairs which the Board of Trade made in the eventful and pregnant period of 1870 to 1886 . The evidence of the officials and the politicians reads like the libretto of one of Gilbert and Sullivan's comic operas, and shows us one road that we can travel if we shall elect to return to the Dark Ages by exalting the Municipality and the State above the man of affairs.

Let us begin with the testimony of the scientists and engineers to the effect that the failure to establish plants for the sale of current to the public was not due to the state of the science of electrical engineering. Mr. George Forbes, F.R.S., formerly Professor of Natural Philosophy, Anderson's College, Glasgow, and at present Electrical Engineer for the works at Niagara Falls, said: "I may say that in 
1882 there was nothing in the engineering question which should have prevented electricity from being economically supplied in a great many cases. In I886, it can be economically supplied in every case that can arise in Great Britain." Lord Ashford queried: "We have had a good deal of evidence generally, not from electricians, that there is a difficulty in distributing from a central station; can you contradict that authoritatively as an engineer?" The reply was: "I cannot more positively than I have already done in my evidence (in chief); there is no doubt about it." Mr. Forbes was very emphatic in his testimony that the Act of $\mathrm{I} 882$ had killed the industry of lighting from central stations. He said he could not conceive of any person investing capital in that industry so iong as it was so heavily handicapped in comparison with its formidable competitor, the gas lighting industry. *

Mr. W. H. Preece, F.R.S., Electrician to the Post Office since $1877, \dagger$ said: "The advance that has been made in our (British) knowledge of the scientific principles underlying electric lighting has been very great, but in practice the development of the industry (in Great Britain) has been very slow. ... The development in the United States has been marvellous; there is no town of any consequence

* Report of Lords Committee on the Electric Light Act, 1882, Amendment Bills, $1886 ; \mathrm{q} .187,188 \mathrm{r}$, and 189 .

$\dagger$ Engineer-in-Chief and Electrician, 1892 to 1899 ; Consulting Fingineer to the Post Office and Colonies, since 1899 . 
that has not its streets lighted by the electric light, and most of the manufactories are being lighted up." $\mathrm{He}$ added that since $\mathrm{I} 882$ the cost of the dynamo had been reduced by one-third, and the output had been increased threefold, which made "the commerical value of the dynamo nine times what it was in I882." *

To Mr. J. N. Shoolbred, who was the consulting electrician to a great many local authorities, a member of the committee said: "Then you differ from those (witnesses) who say that the electric light is merely a light of luxury?" The witness replied: "That expression has been used here, I think, by several witnesses... not in any way as applied to the light altogether, but because in the present circumstances of the law it becomes a light of luxury for those who could afford to lay special installations (of their own) in their houses. That it is not a light of luxury is proved by the number of incandescent lights, not to speak of arc lights, that exist in essentially commercial establishments and industrial works over the country, and subject to the keen competition of commerce, where the new light holds its own against gas light." The witness was further asked: "Are you aware, from your own knowledge, of any industrial works subject, as you say, to keen competition, where the electric light is

* Report of Lords Committee on the Electric Light Act, 1882; Amendment Bills, 1886; q. 1910, 1909, and 2044. 
used in the incandescent form as well as in the arclight form?" He replied: "I am aware of a very large number of various industries that exist about the country in cotton, wool, and silk weaving, and dye works, and lace and hosiery, and a number of other mills . . . also in sugar refineries, and we know that they are running on a very narrow margin and have no money to waste." *

Let us turn now to the evidence of the men who were unable to raise money under the Act of $\mathrm{I} 882$, as well as to the evidence of the men who declined to furnish money for electric lighting ventures under that Act.

Mr. J. S. Forbes, Chairman of Edison \& Swan United Electric Light Co. stated that no shareholder in the company had subscribed for less than $\$ 25,000$ and that "two or three of them happen to be not only large capitalists in London, but the most astute men that I know of anywhere, and they came to the conclusion that the conditions of the concession were so onerous that there was no good attempting to raise any capital for such purpose. ... The Board of Trade, who have no greater admirer than I am for their perfect disinterestedness, tried, and I am bound to say very much, at the instigation of promoters of these Orders, $\uparrow$ to make the

* Report of Lords Committee on the Electric Light Act, 1882, Amendment Bills, I886; q. 248 r to 2483 .

$\dagger$ The witness means that the Board of Trade misjudged the situation, being misled by the "boom" in the shares of the electric companies. 
best bargain they could for the public, and they succeeded in making a bargain which nobody upon the other side now thinks it worth while to carry out." Mr. Forbes added that one of the objections urged by the bankers who declined to underwrite the securities of the Edison \& Swan Co. was that that company had six Provisional Orders, that if four should turn out profitable and two should prove unprofitable, the local authorities would buy the former and leave the latter upon the hands of the company. Mr. Forbes' testimony on the question how new industries are brought into being was exceedingly instructive. He said it was a delusion to suppose that one could peddle out to the general public directly the securities of a company engaged in pioneer work. The public at large would buy only the securities of well-established industries, such as the railway and gas lighting industries. The only purchasers of securities of pioneer companies were the large banking houses. The latter purchased the securities, held them until it had been demonstrated that the new industry would be successful, and then sold them to the general public, who bought in reliance upon the reputation of the banking houses for sound judgment. Mr. Forbes also gave exceeding instructive evidence upon the risk and cost attendant upon the upbuilding of new industries. He said that the Edison \& Swan Co., thus far had expended $\$ \mathrm{I}, 525, \infty 00$, but that to date they had not 
divided one shilling of profit. If they were to be bought out at that time on the basis of "structural" value or "replacement" value, they would get $\$ 144,250$. For patents they had paid Mr. Swan $\$ 300, \infty 00$ and Mr. Edison $\$ 425,000$ * They had eight dynamos that had cost \$10,000 each; equally efficient dynamos could be built in 1886 for $\$ 1000$ apiece. Again, enormous sums had been spent in parliamentary fees in connection with the hearings of the Select Committee on the Electric Lighting Act, 1882 , as well as in connection with the hearings of the committees to which had been referred the Bills for the Professional Orders obtained in $188_{3}$. Upon the losses incurred in unsuccessful experiments, Mr. Forbes commented as follows: "If we had known then what we know now, we should not have spent the $\$ 1,525,000$ as we did, but if we had not spent them, we should not now know what we know." †

The Edison-Swan Co. dismantled the plant built on the Holborn Viaduct in 1882 , before the Act of r882 had been passed. The company also had spent $\$ 80,000$ upon a plant which was to supply 8000 or 9000 lamps in Victoria Station and the neighborhood. An expenditure of $\$ 10, \infty 00$ would

* The testimony of British town clerks was that patents were not " tangible" assets, and that it was foolish, if not reprehensible, for people to spend money on them.

T Report of Lords Committee on the Electric Lighting Act, 1882, Amendment Bills, I886; q. 793 to $795,1009,1028,1029,900$ to $930,863,797$, IOI 5, I006, 80 I to 804 , and 245 to 269 . 
have sufficed to install a plant to light Victoria Station alone. Unable and unwilling to operate under the Act of 1882 , the company confined itself to lighting Victoria Station.*

Sir F. J. Bramwell, D.C.L., LL.D., F.R.S., one of the most eminent engineers of Great Britain, $\dagger$ said: "I have not said it before, but I should like Blighting Effect to say it now. Imagine an industry of the Act of 1882 of this kind competing with an established industry, - gas, - and being gravely told that they may charge such a price as to enable them to get back their capital in that limited time (2I years). It is clear to my mind that those who suggest that cannot understand what the difficulties are. The electric lighting companies will have to go down to the lowest prices to obtain their custom. ... I would say, and it is no use making any secret about it, that I attribute the failure to make greater use of electricity in this country entirely to the character of the Act of r882. I know of no other cause that would have prevented people from

* Report of Lords Committee on the Electric Lighting Act, 1882, Amendment Bills, 1886 ; testimony of R. E. Crompton, q. 282 to 289 and 352 to 359 .

$\uparrow$ Civilian Member of Ordnance Committee since commencement in I881; President Institution of Civil Engineers, I884-85; President Institution of Mechanical Engineers, 1874-75; Chairman of Executive Committee of Inventions Exhibition, 1884; President British Association, 1888 .

In 1895 and 1896 , the firm of Bramwell \& Harris were consulted in reference to a supply of electricity under high tension from the Catskill Mountains to New York City, from Mount Cenis to Turin (II,000 h.p.) and from Simplon to Milan (23,000 h.p.). 
embarking their capital in an undertaking of that kind." Lord Ashford asked the witness: "You have had very great experience of Parliamentary Committee Rooms: would you not think that a Bill like that of Lord Rayleigh, which did not provide for purchase at the end of any number of years, would find some difficulty when it got into another place (the House of Commons) in a Committee Room?" The reply came: "It really depends upon the present condition, and I speak with all respect, of the craze for making local authorities into traders, that is, whether on the flood or the ebb." *

Mr. J. M. Macdonald, a partner in Matheson \& Co., Lombard Street, said the Act of 1882 would effectually deter any investors because of the compulsory sale clause. Lord Houghton queried: "You said just now that what the public objected to was an undue profit. Why should they object to the companies making large profits if the price is not high; in what way is it against the public interest?" The witness replied: "I think it is an unreasonable objection; but I must recognize that it does exist. There is a prejudice against what people call an unearned increment." $\dagger$

Mr. Lionel Cohen, M.P., late senior partner of

* Report of Lords Committee on the Electric Lighting Act, 1882, Amendment Bills, IS86; q. 786, 377, 378, and 58o.

$\dagger$ Report of Lords Committee on the Electric Lighing Act, 1882, Amendment Bills, I886; q. 1088 to 1092, and II 10. 
Louis Cohen \& Sons, an eminent Stock Exchange firm, said: "I consider that the Act of 1882 has not only retarded electrical enterprise, but that it is almost prohibitive to the finding of capital, under the compulsory sale clause. ... Then again, it seems to me that the number of fetters and conditions with which the Act bristles at present, I do not know whether they are necessary in an engineering point of view, would certainly deter prudent people. . . . What a man looks for when he invests his money is to have a clear and simple undertaking which he can understand for himself, without the aid of a lawyer, or even of a broker. . . . But it is utterly impossible to attract capital if it bristles with so many precautions and compensations as this Act seems to have."

In the course of Mr. Cohen's testimony, the Chairman of the Committee, the Earl of Camperdown, said: "It is to be feared that we should find some difficulty in persuading Parliament to reconsider the decision arrived at in 1882 , to the effect that it was not expedient to allow the creation of any new permanent interest - " that is, to abandon the principle of compulsory sale.*

Mr. Henry Hucks Gibbs, senior partner in Antony Gibbs \& Sons, Bankers, a Director in the Bank of England, and one time Gavernor of the Bank of

* Report of Lords Committee on the Electric Lighting Act, 1882, Amendment Bills, 1886; q. 7,9, and 14. 
England, supported the testimony of the preceding witness.

Let us turn now to the consideration of the evidence by means of which the town clerks, the town councillors, and the Permanent Secretary of the Board of Trade, Sir H. G. Calcraft, broke the effect of the testimony of the scientists, engineers, and capitalists, and persuaded the Salisbury Government that it was useless to attempt to carry in the House of Commons an amendment to the disastrous Electric Lighting Act, I882, that would be satisfactory to the capitalists.

Mr. E. O. Smith, Town Clerk of Birmingham since $\mathrm{r} 88 \mathrm{I}$, appeared in the double capacity of representative of the corporation of Birmingham and representative of the Association of Municipal Corporations. He protested against the Bills of Lord Rayleigh and the Earl of Camperdown, but was willing "for purpose of conciliation" to accept thirty years as the life of a charter. He also consented "unwillingly" to the Board of Trade having power to overrule the veto of the local authority upon a company's application for a charter. He said: "All we ask is this; we have been burnt in gas and water; we do not want to be burnt again in electricity. That is the sum and substance of the evidence I can give on behalf of the corporations" (municipalities). Lord Rayleigh asked him whether this was his idea of being burnt: to reduce the price of gas from 
74 cents per 1000 cubic feet in 1875 to 52 cents in I 885 , to pay interest and sinking fund payments on an investment of $\$ 10,000,000$, and to have left a profit of $\$ 125,000$ a year. Mr. Smith replied: "It was a good bargain for the corporation, but it might have been a great deal better." Lord Bramwell* queried: "That is to say, you would like the electric light companies to risk their money upon terms, that if it is a failure, it shall be their risk, but if it is a success, it shall be at your profit?" The witness replied that the statement was very broad and not true, for, "assuming the companies do not commence operations until electrical science has developed rather more, I conceive under the terms of the Government Bill, it is possible they may make a very good profit, and get all their money back at the end of the time.... I preface my answer by saying, if they waited till the proper time. I do not think at present $\dagger$ there is scope for a company. . . . I think electrical science is not sufficiently advanced for people to venture their money in electrical speculations. . . . I should not put my money into it, but I do not see any necessity for people to put money into a thing unless it will pay." "Yes, if

* Baron of the Exchequer from 1856 to 1876 ; appointed a Lord Justice of Appeal in 1876, and retired from the bench in $188 \mathrm{r}$. Was made Baron Bramwell of Hever, in I 882. "Every good man has been at some time of his life a socialist, and, if wise, very soon ceased to be one," he often said. The Times Biographies, Vol. IV.

$\dagger$ At the close of 1885 , there were in operation in the United States 167 central electric stations. 


\section{MUNICIPAL OWNERSHIP IN GREAT BRITAIN}

they were not in too great a hurry to begin," was the reply to Lord Bramwell's repeated query: "You say that you think, provided the companies waited a few years until electricity was rather further developed, they would have a fair chance of making a fair return on their money under the Government Bill?" In replies such as these the Town Clerk of Birmingham and Representative of the Association of Municipalities sought refuge, when pressed to state how electrical engineering could advance without practical experience.

Sir George Morrison, Town Clerk of Leeds and Representative of I7 I Municipalities, was asked whether the sliding scale and auction clauses in Lord Rayleigh's Bill would not sufficiently protect the consumer. He replied: "That is not my objection to the Bill. I do not doubt but that the sliding scale would be all right, other things being upon the footing I desire, namely, the Purchase Clause." The Chairman queried: "In your evidence you have assumed throughout that the terms offered by the Government Bill are sufficiently good to enable capital to be found; that is your opinion?" The witness replied: "I have not quite put it as high as that; with deference, I put it that as soon as ever electric lighting gets into a condition to be workable in towns (in competition with gas), those terms are sufficient. . . . I do not think the public generally would advance their capital to electric 
light concerns unless they were pretty sure it would cut out gas as an illuminant, ... I think they would require to be shown that as an illuminant the price would not be materially greater than that of gas; I should require it certainly." To the query: "I understood you to say that, supposing electricity were able to compete with gas, you are of opinion that there would be no difficulty in securing capital to forward electric lighting undertakings," Sir George Morrison replied: "I should think not; and moreover, there would not be the necessity in many cases (of inducing capital to take it up), because large corporations (municipalities) would themselves immediately take it up."

Sir George Morrison capped the climax by stating that there was no necessity of putting the electric light on a footing of equality with gas, as Lord Rayleigh's Bill proposed to do. The city of Leeds, on the "very confident" advice of its engineer, had found a substitute for electrical energy, namely, compressed air and hydraulic power. The city was negotiating with two companies that were going to apply for charters to install compressed air and hydraulic power plants, and were ready to agree to sell to the city at the expiration of thirty years on the basis of structural value. As soon as the compressed air and hydraulic power were available, there would be no further need of electric light companies, "Because each householder 
may install his own dynamo in his own house, and, assuming (the compressed air and hydraulic) power to be laid on, he may use the system and machinery for lighting purposes in the night, which machinery and system may also be used a second time for his ordinary manufacturing business during the day. Under the compressed air and hydraulic power bills there is a very strong argument to be adduced to the effect that there is no necessity to give electric lighting companies such a position as is now sought, when the compressed air and hydraulic power companies will do half the work (lighting) at a much less cost. That is a matter of opinion, but our engineer has advised the lighting committee of the corporation very confidently. We are supporting the Bills, having the view that compressed air will be a most valuable and potent factor in the supply of power."* In 1902, Leeds had 437,000 inhabitants.

Mr. C. Dunscombe, City Engineer of Liverpool, supported the opposition to Lord Rayleigh's Bill and the Earl of Camperdown's Bill with the argument: "I do not think any electric lighting companies are paying a dividend at present, but such undertakings ought not to be embarked upon if there is not a reasonable possibility of the companies paying a small rate of interest upon the invested capital in

* Report of Lords Committee on the Electric Lighting Act, 1882, Amendment Bills, 1886 ; q. $1847,1631,1887,1697,1698,1694,1882$ to I 839,1667 to 1683,1872 to 1875 , and $165^{2}$ to 1657 . 
the first few years of their life." At the conclusion of the evidence, Lord Ashford said to the witness: "I was going to ask you some engineering questions based upon your answers; but I have elicited from you that your answer to the Chairman was really in nature of a guess, and not founded upon a mathematical calculation, therefore I cannot pursue that." *

Mr. George Whiteley appeared as the representative of Blackburn, of which town he had been the Mayor in 1885 , and was an alderman in $1886 . \mathrm{He}$ said Blackburn was the chief manufacturing and chief weaving centre of cotton textile fabrics in the world. He was himself a cotton spinner and weaver, and he stated that an electric light practicable as to price would be a great boon to the cotton industries. He argued that if an electric light company could not recover its capital in eighteen years by setting aside each year a sinking fund contribution to be invested at 3.5 per cent compound interest, "that is an argument why it should not be formed or worked." In reply to the argument that the electrical engineers could not develop their science if they were denied the opportunity to acquire experience, Mr. Whiteley said he objected to an electric light company being given power to break up the streets for the purpose of laying its wires, on the ground that the light was a luxury. The corporation of Blackburn would

* Report of Lords Committee on the Electric Lighting Act, 1882, Amendment Bills, 1886; q. 1485 and 1511 . 
not put in an electric light plant until the light were "a benefit to the inhabitants" (at large) and then the damage done to the streets would be compensated by the benefit accruing to the community from the electric light.* To this doctrine that the streets should not be utilized for the purpose of affording companies experience, subscribed also Sir George Morrison. Since I893, Mr. Whiteley has been a member of Parliament. Blackburn in 1902 had I 29,000 inhabitants. The corporation of Blackburn obtained an electric lighting charter in I89o and, after sitting on it for four years, began to supply current in February, I895.

Let us conclude the consideration of the testimony on behalf of the municipalities with the evidence of Sir H. G. Calcraft, Permanent Secretary of the Progress not Board of Trade from I 886 to I 893 . worth its Cost Sir H. G. Calcraft argued in favor of compulsory sale at structural value, on the ground "that all experience will show that when companies have to be bought up as a going concern, the sum of money to be paid to them is very large indeed, and the public is put to unnecessary expense." In reply to the question of Lord Ashford whether it was unjust that a company should reap the benefit of success in case it went into a venture upon which the municipality did not care to embark, because of the

* Report of Lords Committee on the Electric Light Act, 1882, Amendment Bills, I886; 1528 to 1540 . 
uncertainty of the venture, the Secretary of the Board of Trade said, "I think if it is the case that it is very doubtful whether the thing will turn out very well or moderately well, and then it turns out better than is anticipated, the public ought to have the advantage" (benefit of the doubt). In reply to the query, "That is to say, that the undertakers ought to run the risk of failure, and the public ought to have the benefit of success?" the Secretary of the Board of Trade replied, "It is not necessary for the undertakers to take it up." Lord Rayleigh queried, "When you say it is not necessary for the undertaker to take it up, you mean that it is not necessary that the public should have the electric light." The reply was, "The local authority may take it up." Lord Rayleigh continued, "Supposing the local authorities do not see their way to taking it up, what then?" The reply came, "Then I suppose it would be postponed for a period." Lord Rayleigh, "The whole of your argument seems to come to this: that it is less important that the public should have the light, than that the companies should not make the profits?" The Secretary of Great Britain's Board of Trade, "I think it is essential that the public should not pay too highly for it" (the plant).*

The testimony given before the Select Committee showed that the municipalities would consent to

* Report of Lords Committee on the Electric Light Act, 1882, Amendment Bills, I886; q. 2207 and 2280 to 2303 . 
nothing more than the extension of the life of franchises to thirty years, and that capitalists would not take up electric lighting on that basis. Therefore, the Government abandoned the effort to amend the Electric Lighting Act, I882. Rather than ask its supporters in the House of Commons to offend the powerful association of Municipal Corporations, the Government concluded to let the people of the United Kingdom go without the electric light. In I 887 and I 888 the Board of Trade issued no Provisional Orders or charters. In the last-mentioned year Lord Herschel, who had been a member of the Government responsible for the Act of 1882 , felt justified in saying in the House of Lords, "He believed that in the South Sea Islands the electric light was more used than it was in London." 


\section{CHAPTER XIV}

THE CITIES CONFESS THEIR INCOMPETENCE TO TAKE HOLD OF A NEW INDUSTRY

IN I882, a Committee of the city of Birmingham reported against the corporation undertaking to supply electric current for lighting purposes, on the ground that the corporation was not capable of taking up an unestablished industry; and the corporation indorsed the report of its sub-committee. The report in question is one of the most important and illuminating documents in the history of municipal ownership in Great Britain, wherefore it is here reproduced at length, from the Journal of Gas Lighting, Water Supply, and Sanitary Improvements.*

The Committee reports: "They do not think that the interests of the (municipal) gas supply, as the principal lighting agent, are threatened by the Report of Bir- proposed new illuminant. If these mingham Com- interests were so threatened, the mittee of 1882 Committee, while they would recognize the seriousness of the situation, believe that it would be their duty, on the one hand, to con* Vol. XL, I882, p. 788. 
sider the question of electric supply and to promote the supply, with a sole regard to the general convenience of the inhabitants of the town; and, on the other hand, to continue to develop in every possible way the new fields for the employment of gas which are every day presenting themselves, and to persevere boldly in any expenditure that will cheapen its production. . .

"Further, the new system, if successful, will be of immense importance to the manufactures in which Birmingham and the district are particularly interested; and for this reason alone, the town will probably be anxious that facilities should be afforded for the experiment, provided that the inconveniences (due to laying wires under the strect surface) attending it can be minimized to the fullest possible extent.

"The Electric Lighting Act, I882, has been passed with the special view of preventing the establishment of a monopoly. More than one undertaking may be authorized in the same area; and it should not be overlooked that if the system proves successful in a limited area (to which the corporation proposes to confine a company), the corporation may apply for powers to supply in such area (in competition with the company) or in the remainder of the Borough. A license can only be granted (by the Board of Trade) with the consent of the Local Authority, and for seven years. It 
cannot be renewed without the consent of the Local Authority. A Provisional Order granted to a private company may be terminated by purchase of the electric plant, on favorable terms, by the local authority at the end of twenty-one years, or such shorter terms as Parliament may impose, or as may be arranged by agreement.

"The most sanguine supporter of electric lighting does not claim that the proposed system of distribution (of electric energy) would be free - at any rate for some time to come - from difficulties, imperfections, or even failures. These would certainly be attributed (if they occurred in a municipal plant) by rival companies either to the use by the consumers of the wrong lamp, or to the use by the undertakers (the municipality) of the wrong dynamo. It is conceivable that, the supply being in the hands of a local authority, with generating plant recently put down, consumers who had purchased costly fittings, and who were impatient underimperfections or difficulties which had manifested themselves in this experimental work, would demand that the dynamo in use should be abandoned in favor of some other form which for the moment attracted (the popular) attention. It is also most important to remember that whatever the cost of supplying electricity is found to be, the undertakers will be subject to great pressure by consumers to supply it at the same cost (price) as gas, or at least at prime cost. 
Local authorities, having already the supply of gas in their hands, will have additional difficulties in this respect, as, even if supplying electricity at prime cost, they will be suspected especially by others seeking powers to establish a rival system, or by agents eager to sell lamps - of unduly keeping up the price in order to foster the gas supply.

"The Town Clerk is of opinion that the meaning of section I 9 of the Act is not clear. It is, therefore, necessary to point out that, under this section, it may be contended that the undertakers will be under an obligation to supply electricity in any part of the selected area. In that event, this would be a serious obligation; as it might, and probably would, involve the laying of conductors over the whole area for a very limited consumption. . . .

"On consideration of the requirements, it is obvious that if the Council decided to apply for powers, they must at once obtain special professional help; that it would be necessary to rely solely on that help, and to accept the responsibility of taking action on technical and commercial matters involving heavy responsibilities, and possibly parliamentary opposition, without experience to guide them or their advisers in the matter (the industry being not yet established). ... .

"The Committee do not think it can be said that electricity is at present a public necessity. Dr. Siemens (of Siemens Brothers \& Co.) has said that 
electricity is the light of luxury, and that gas is, and will be, the poor man's friend. The Committee, not differing with Dr. Siemens, quote his authority in support of their opinion; and are unable, so far as regards this reason, to recommend the expenditure of any portion of the corporate funds in an experiment for the advantage of a portion only of the community.*

"Your Committee, having regard to the difficulties and grave responsibilities which, in the present state of knowledge on the subject, appear to be inseparable from the undertaking, have considered whether any disadvantages would result to the town if the support of the corporation is given to the granting of authority to electric lighting companies to undertake the supply (in Birmingham). They report, after careful consideration of the subject, that it does not appear to them that the rate-payers will be in any way prejudiced by the establishment of one or more companies in limited areas of supply, . . . that it will not be difficult to arrange that the concession shall be made for a moderate term (of years).

"Reviewing these considerations, the Committee are of opinion that there is no analogy between the proposal that the Council should undertake the supply of gas and that they should undertake that of

* This statement is consistent with the opening statement that it. would be "of immense importance to those manufactures in which Birmingham is particularly interested." 
electricity, and that in most important particulars the circumstances are wholly different. The Council were prepared - and, indeed, they thought it advisable - to accept largely increased responsibilities with the transfer (purchase) of the gas undertaking (in 1875); but those responsibilities were chiefly as to the commercial conduct of the (established) business. They had as a part of the transfer a trained and skilful staff, with long cxperience of the business, on whom they could rely. Their first responsibility with regard to the supply of electricity would be the selection of an untricd staff, chosen of necessity from men without experience of the obligations to be incurred, and for whose mistakes the corporation would be blamable. With the transfer of the gas supply, profits over and above those possible to the companies were at the disposal of the corporation.* The result of an undertaking to supply electricity would almost certainly impose an immediate burden on the rate-payers, with the ultimate prospect of a considerable loss. It is known that the principal difficulties of the proposed system lie in the distribution of electricity (without undue loss). Apart from cost, the difficulties of the generation of electricity and the construction of lamps may be said to have been overcome. A local authority

* The argument is that corporations can work more cheaply than companies because they save the salaries of president, directors, etc., and because municipalities can borrow money at lower rates of interest than companies can borrow. 
undertaking the supply of electricity, under the most favorable circumstances, would have on its hands the costly and difficult part of the supply (namely, the distribution from the plant to the consumer). It would, however, be serving the interests of companies* whose profits are made by royalties on, or the manufacture of, dynamos, plant, and lamps, who would be able to attribute all the imperfections and failures of the system to the source of supply, and to whose interest it would be to foster a continual agitation for cheaper electricity.

"The Committee believe that no sufficient reason can be shown to induce the corporation to enter on a work which cannot fail to bring it anxieties, difficulties, and arduous labors, without the recompense of contributing to the welfare of the community as a whole; and which would involve financial responsibilities, with the uncertainty of adequate, if any, return. If, on the other hand, the companies are allowed to take the management of the supply, they will undertake the responsibilities and difficulties appertaining to it. At the end of the term which is agreed upon, or which Parliament determines as sufficient compensation to the company, the corporation will have the same opportunity, but on more favorable terms, of acquiring the property, and will, if it has become profitable, have the same induce-

* The words of the town councillors of one of the greatest trading and manufacturing cities in the world. 
ment, in the saving of interest on capital employed, as it had when it purchased the gas undertaking. The Committee believe, however, that gas, when properly used, will hold its own as the most effective and reliable illuminant, and that it is possible to free it from much of the opposition to which it is now liable, by showing on every opportunity that the objections urged against it are not inseparable from its use." *

A more detailed and emphatic confession of utter incapacity of a municipality to take hold of and build up a new industry one cannot imagine. Nor The Value of can one imagine a more brazen and Experiment and shameless attitude of mind than was Experience that of the authors of this document, full of slurs against private enterprise, yet proposing to use that private enterprise for the performance of a task for which the authors of the document said they had neither stomach nor capacity. Mr. E. O. Smith became Town Clerk of Birmingham in $\mathrm{r} 88 \mathrm{I}$; he knew this document as well as the schoolboy knows his reader; and yet, in r886, he argued before the Committee of the House of Lords that Birmingham was "burnt" when it was made to pay the market price for an established gas plant, with an established clientelage, and a trained staff familiar with the engineering science of gas manu-

* Many wealthy English families never have admitted gas into their houses, on the ground that it injures the health and destroys fabrics and impairs paintings. 
facture and supply - a science built up by men who shirked neither "anxieties, difficulties, and arduous labors," nor the risk of losses through ill-fated experiments. Sir H. G. Calcraft, Permanent Secretary of the Board of Trade from I886 to I893, also must have been familiar with this document, as well as with the fact that, broadly speaking, the municipalities had originated nothing in water supply, gas supply, or street railways. And yet, in I886, he argued that municipalities were put to "unnecessary" expense when made to remunerate private companies for having built up an industry. It should have been obvious to the Permanent Secretary of Great Britain's Board of Trade that if municipalities cannot develop industries, and private enterprise will not develop them unless it can obtain its price for such work of development, then that price is as much a part of the necessary cost of an established industry as are the stone, brick, mortar, iron, and steel that go into the plant.

Shortly after the enactment of the Electric Lighting Act, 1882 , five or six companies* served notice upon the Birmingham Town Council that they had applied to the Board of Trade for Provisional Orders for the area of Birmingham, some of the companies intending to supply current over the whole of Bir-

* Report of Lords Committee on the Electric Lighting Act, 1882, Amendment Bills, I886; q. 1223, I162, I250 and I25 I, Mr. E. O. Smith, Town Clerk of Birmingham. 
mingham. All of the applications excepting that of the Incandescent Electric Lighting Co., Ltd., were subsequently withdrawn. The corporation agreed with Messrs. Crompton and Winfield, electrical engineers and contractors who constituted the Incandescent Electric Lighting Co., not to oppose before the Board of Trade that company's application for a charter, if the company would agree to sell its plant at the end of sixteen years on the basis of "profits up to date," but with no allowance for future profits. The company agreed also to confine its operations to the "very centre" of Birmingham. The city insisted upon that restriction because it wanted a company only sufficiently large to prove that the electric light could compete with gas. It was opposed to having any larger company, for the larger and the more successful the company should be, the more the city would have to pay for its plant and good-will at the end of sixteen years.* Messrs. Crompton and Winfield were unable to raise money, and in 1886 the Board of Trade, upon the application of the city of Birmingham, revoked their charter. Thereupon, Messrs. Crompton and Winfield applied to Parliament for a Private Act on the terms of the Private Acts given to gas companies. But the Board of Trade opposed the application on the ground of violation of the spirit of the Act

* Report from the Select Committee on Municipal Trading, 1900; q. 1957, Mr. E. O. Smith, Town Clerk of Birmingham. 
of I882, and Messrs. Crompton and Winfield withdrew.*

In I889, after the life of electric lighting charters had been extended to forty-two years, the Birmingham Electric Light and Power Co. applied to the Board of Trade for a charter for the whole of the city. The corporation of Birmingham still was afraid to embark in electric lighting, $\uparrow$ though there were at this time in operation in the United States about 675 central electric stations. The corporation agreed not to oppose before the Board of Trade the company's application for a charter, if the company would consent to the Board of Trade restricting its charter to a very small area in the centre of the city, $t$ and would also give the city the option to purchase the plant after a short period.

The company began to supply electricity in April, I89I, and "as soon as it proved to the corporation that it was doing very well," $\S$ the corporation bought it out, paying it $\$ 2,100,000$ for an investment of $\$ \mathrm{I}, 095,000$. The plant was transferred to the city

* Report of Lords Committee on the Electric Lighting Act, I882, Amendment Bills, 1886; q. I I62, Mr. E. O. Smith; and q. 282, 292, 293 , $330,347,348,349$, and 358 , Mr. R. E. Crompton.

$\dagger$ Report from the Select Committee on Municipal Trading, I900; q. I957, Mr. E. O. Smith, Town Clerk of Birmingham.

+ Report by the Board of Trade, respecting the Applications to and Proceedings of the Board of Trade under the Electric Lighting Acts, for the year I889, says that "the application for the Birmingham Order originally included the whole city. The area in the Order as granted was, however, restricted to a district in the centre of the city, at the request of the local authority."

$\S$ Report from the Select Committee on Municipal Trading, 1900; q. I957, Mr. E. O. Smith. 
in January, I900, and thereupon the city took steps to supply current to the whole city. Thus the city of Birmingham for fully eighteen years prevented the people outside of the "very centre" of the city from having the electric light; and after having inflicted that hardship, it ended up with paying $\$ 2,100,000$ for a plant that had cost $\$ 1,095,000$ - the very thing it had sought to avoid.

In 1903 there were in Birmingham, a city of $55^{2,000}$ people, only 2I 35 customers of the electric light plant. That is, in every 259 inhabitants was an electric light customer, using, on an average, 47 lamps of 16 candle-power.* In Boston proper, a city of about the same size as Birmingham, $\mathrm{I}$ in every 73 inhabitants was an electric light customer in 1900, using, on an average, 49 lamps of 16 candle-power.

\section{LIVERPOOL}

In 1879 to 1882 Liverpool, Blackpool, Over Darwen, Hull, Lancaster, Oldham, and Irvine Burgh obtained Acts of Parliament authorizing the local authorities to instal plants for lighting the streets electrically. $\dagger$ All of the cities failed to achieve their purpose, except Blackpool, which lighted the streets electrically from I 884 on, but did

* Garcke's Manual of Electrical Undertakings, ino4.

$\dagger$ Report of Committee on the Electric Lighting Bill, 1882 ; q. 23 to 25, Mr. T. H. Farrer, Permanent Secretary to the Board of Trade; q. I254 and I I I5, Mr. J. Raynor, Town Clerk of Liverpool; and q. 2470, Mr. C. W. Siemens. 
not supply current to private consumers until I893.* After the city of Liverpool had failed, it made contracts, in 1880 and I882, with private companies for lighting the streets, but the companies "failed financially." $\uparrow$

Liverpool had nothing further to do with electric lighting until I889, when it consented to the Board of Trade issuing a Provisional Order to the Liverpool Electric Supply Co., Ltd., under the conditions described as follows by Sir T. Hughes, Alderman of Liverpool since 1878 , Mayor in 1889 , and Lord Mayor in 1897 . "The Liverpool Electric Supply Co. got their Act with the good-will of the corporation, the corporation taking care to protect themselves by getting power to buy out the company within seven years. The corporation felt at that time that electric light was in a sort of experimental stage which would not warrant the corporation in embarking the capital of the taxpayers in the undertaking. But the company were willing to take all the risk, and, therefore, with the good-will of the corporation, they got their Act, the corporation taking care that if it did turn out a success within seven years, they should have the option of taking it within that time." $\ddagger$ In 1896

* Report from Select Committee on Municipal Trading, I900; 383I, G. C. Kingsbury, Mayor of Blackpool.

$\dagger$ Report of Lords Committee on the Electric Lighting Act, I882, Amendment Bills, I886; q. I464, Mr. C. Dunscombe, City Engineer of Liverpool.

$\ddagger$ Report from the Select Committee on Municipal Trading, 1900; q. 2204 and 2 I 74 . 


\section{MUNICIPAL OWNERSHIP IN GREAT BRITAIN}

the city paid the company $\$ 2,000,000$ for a plant that had cost $\$ 1,250,000$. In the words of Sir T. Hughes: "The corporation felt the company had been an enterprising company and had developed the thing very well, and that therefore they were entitled to a fair profit on the capital which they had risked on what was at one time somewhat of a speculation." Under the terms of the bargain, prudence compelled the company to confine itself to a restricted area; it could not try to develop business that required time to build up. In 1902, six years after the city had taken over the plant, there were in Liverpool, a city of 702,000 inhabitants, 4790 electric light customers. One inhabitant in every 146 inhabitants was an electric light customer, using, on an average, 46 lamps of 16 candle-power.

\section{MANCHESTER}

In 1889 six companies applied for charters for Manchester. In order to keep them out, the city itself obtained a charter from the Board of Trade, in 1890 . In I 893, the city began the supply of current in an area of four square miles in the heart of the city. In 1898 the city took steps to supply current in the remaining sixteen square miles of the city, by preparing to enlarge its plant from 20,000 horsepower to I 20,000 horse-power.* In I900, Mr. J. W.

* Report of Joint Committee on Electricity Generating Stations and Supply, 1898; q. 1260 to 1271, Mr. L. Higginbottom, Alderman in Manchester and Chairman of Electricity Committee. 
Southern, who had been an alderman in Manchester since 1878 , stated before a Parliamentary Committee that the demand for current was in excess of the city's power to supply. "We have' a very large number of persons who have applied to be connected as soon as we can give them power." Mr. Southern added that the demand came chiefly from small manufacturers who wished to install three and four horse-power motors. The extent to which the city was preferring the public treasury to the needs of the small manufacturers, and the convenience of the householders, is indicated by the fact that in $1898-99$ the city applied $\$ 60,000$ of the profits made by the electric light department to the relief of the rates (taxes).* In i 903 , one inhabitant in every 84 inhabitants was a customer of electric light, using, on the average, 34 lamps of 16 candle-power.

\section{SHEFFIELD}

From r 889 to 1891 , inclusive, the city of Sheffield kept the electric light companies at bay by opposing before the Board of Trade the applications of com-

* Report from the Select Committee on Municipal Trading, 1900; q. 2464 to 2466 .

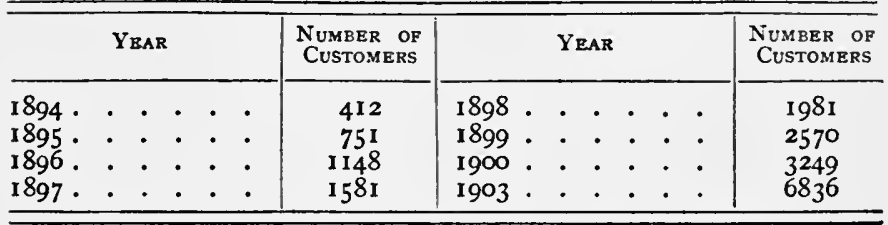


panies for charters. In 1892 it admitted the Sheffield Electric Light and Power Co., Ltd., on condition that the company should sell to the city at an early date, if the city should care to purchase. The company began to supply current in March, I893; and in December, I898, the city bought it out, paying $\$ 218$ for every $\$ 100$ invested.*

\section{LEEDS}

Leeds, which in 1902 had a population of 437,000 , will be remembered as the city which in I 886 came to the conclusion that public necessity and convenience did not demand the development of the science of electrical engineering, since compressed air and hydraulic power were going to enable every householder to install in his basement his own dynamo!

Leeds kept the electric lighting companies at bay in 1889 and 1890 , and in $189 \mathrm{I}$ it admitted the Yorkshire House-to-House Electricity Co., Ltd., on condition that the company should agree to sell within a few years, if the city should care to purchase. The company began to supply in May, 1893; and in December, 1898 , the city bought it out. For the company's capital expenditure,

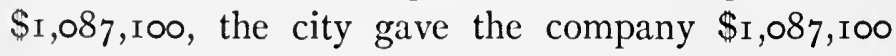

* Report of Joint Committee on Electricity Generating Stations and Supply, 1898; q. 1536, 1605, and 1607, Mr. G. Franklin, Lord Mayor of Sheffield. 
in 5 per cent stock of the city of Leeds. In I902, one inhabitant in every 175 was a customer of electric light, using, on the average, 32 lamps of 16 candle-power.*

\section{NOTTINGHAM}

Nottingham, which in 1903 had a population of 240,000 , obtained an electric light charter in 1890 , in order to keep the companies out. It was afraid to install a plant, and therefore it proceeded to "sit on" the charter. The companies continued to apply to the Board of Trade for charters, pointing out that the city of Nottingham was not using its powers. In order to stop the agitation of the companies, the city supplied current in September, 1894. "It did not expect it to pay, but started in order to keep out a company that was applying." $\dagger$ From 1894 to 1898 , inclusive, the city made no effort to develop business. In 1898 it had only 482 electric light customers. The city owns the gas plant.

* Garcke's Manual of Electrical Undertakings, Vols. IV and VIII.

$\dagger$ Report of Joint Committee on Electricity Generating Stations and Supply, 1898; q. 1378, 1379, and 1406, Sir Samuel Johnson, Town Clerk of Nottingham since $187 \mathrm{I}$.

$\ddagger$ Garcke's Manual of Electrical Undertakings, Vols. III to VIII.

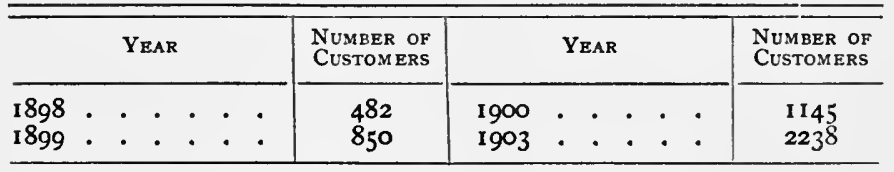




\section{EDINBURGH}

The corporation of Edinburgh obtained an electric lighting charter in $189 \mathrm{I}$, but it did not supply current until April, I895. The corporation owned the gas plant. Moreover, "many of the poorer people looked upon the acquisition of the electric lighting by the corporation as rather a hardship; as being more in the nature of a luxury for which they ought not to pay." *

\section{GLASGOW}

In 1889 or 1890 , Messrs. Muir, Mavor, and Coulson, Limited, a so-called "marauding" company, applied to the Board of Trade for an electric lighting charter. The Board of Trade gave the charter to the corporation of Glasgow, which bought the plant of Messrs. Muir, Mavor, and Coulson, Limited, in I892, and thereupon began the supply of current.

In I900, Mr. James Kelly, a Magistrate for Glasgow, stated before a Parliamentary Committee, "I know that private firms have put in their own electric power, who would have taken it from the corporation, if it had been available." At that time the corporation had only fifty-six miles of mains. At the same time, Mr. Samuel Chisholm, Lord

* Evidence taken before the Telephones Committee on the Question of Adequacy of Telephone Service in Local Areas, 1895; q. 2282 and 2290, Mr. A. Reach, Editor of "The Edinburgh Evening Dispatch." 
Provost of Glasgow, testified as follows: "We obtained powers to supply electricity within the city boundary in 1890 . We carried it on without any great energy for some years. ... We expect to be ready this winter to supply practically the whole city with electricity." The Chairman of the Committee queried: "You account for your failure to push electric lighting at the beginning by the fact of the corporation taking more interest in their largely gas undertaking?" The Lord Provost replied: "Yes, I think that was really the explanation. There was the natural caution also which the corporation properly felt about a comparatively new and untried enterprise, which in 1890 electric light was for domestic supply." The Chairman replied: "It has been stated by several witnesses that industrial progress has been checked by allowing corporations to work their own enterprises. . . Do you admit that that has been so to some extent, as regards your electric lighting; it appears to me that in answer to some of my former questions you made admissions that amounted almost to that?"

The Lord Provost's ideas concerning the part that municipalities are to play in the work of building up new industries are revealed in the following statement: "As a matter of fact, I am not sure but that Glasgow has gained ultimately by its dilatoriness at first, because during these years when we were lying fallow and doing little, there were various improve- 
ments that were made. We learn from other people's experience; we had deputations visiting various places in England and on the Continent, and we gained experience during those years, and when we did launch out to a larger extent, we were able to do it to greater advantage than if we had done it first." *

* Report from the Select Committee on Municipal Trading, 1900; q. 2724 to 2735,2808 and 2809 . 


\section{CHAPTER XV}

\section{THE MUNICIPALITIES versus THE CONSUMER}

AFTER the electric lighting industry had been completely paralyzed in Great Britain for six long years - so far as the supply of current from central stations was concerned - the Association of Municipal Corporations permitted the House of Commons to pass the Salisbury Government's Electric Lighting Act, I882, Amendment Bill, I888** There was no debate upon the Bill in the House of Commons. In the House of Lords, Lord Thurlow introduced the Bill with the words: "The object of the Bill was to remove what had proved prohibitive restrictions upon an industry which deserved every support. . . . In almost every large town in Italy electric lighting was making rapid progress. It was only in England that the science was comparatively at a stand-still." $\dagger$ The reader will remember, however, that in Germany also the industry was completely paralyzed at this time.

The Act of 1888 retained the principle of compulsory purchase at cost of replacement, but length-

* 5 I and 52 Vict., c. I2, June 28 , I 888.

$\dagger$ Hansard's Parliamentary Debates, March 5 and I2, I888. 
ened the life of charters to be given to companies to Act of 1888 aimed forty-two years, or such shorter period to remove Prohibi- as the Board of Trade might fix. It tive Restrictions retained, also, the provision that, if a local authority should not care to purchase at the expiry of the period fixed, - on the ground that the plant had not yet become sufficiently profitable to make purchase desirable, - then it should have the right of purchase at the end of every recurring period of seven years. This provision, it will be remembered, is inserted also in all tramway and light railway franchises.

The condition upon which the Association of Municipal Corporations permitted the House of Commons to accept the Bill of I 888 was that the local authority concerned should have the right to register a protest against the Board of Trade issuing a charter to a company, and that the Board of Trade should overrule such protest only on condition of making a written statement to Parliament of the reasons for its action. The municipalities had asked for the unqualified veto, but the Government had been unwilling to grant that, because of the manner in which the local authorities had abused the veto power given them by the Tramways Act, r870. But in Great Britain, as in all other countries, there is often a vast difference between a law as it reads and a law as it works. In effect, the power of protest of the local authorities became the power of 
unqualified veto, and remained such until the Report from the Joint Committee on Municipal Trading, I900, made public the evidence as to the scandalous manner in which the Board of Trade was administering the Act of I888. Even to-day the power of protest in the hands of the local authorities is not much short of the power of veto. The reason for this difference between the wording and the working of the law is that in Great Britain, as everywhere else, the Government of the day has constantly to consider the effect of its administrative policy on its political fortunes. The men who constitute the British Ministry are great party leaders, and they must constantly have a care not to lose support in the House of Commons, and still more, not to alienate the constituencies of their supporters in the House of Commons by adopting an administrative policy that would arouse determined opposition among the electors at large, or even among a comparatively small but highly organized and vociferous body of electors.

When Parliament refused, in 1888 , to give the local authorities anything more than a "provisional veto," it reaffirmed the decision at which it had arrived in 1882 . The motives for that decision were set forth at length, in 1883 , by Mr. T. H. Farrer, who spoke from knowledge gained "from having been present at the whole sitting of the Committee" (on the Electric Lighting Bill, r882). He said: "It was 
undoubtedly the intention of the Committee of last session, that the Provisional Order should be made use of as a means of inducing, and to some extent compelling, inert local authorities to admit this new invention. Now if it is in the power of a local authority, by simply saying: "We will not go into the merits of the case (of the demand by a company for a Provisional Order), we simply stand upon our non volumus,' it seems to us that there would be an end to Provisional Orders altogether. ... It was felt that whilst local authorities represented the ratepayers, they were in many cases inert bodies not willing to adopt new things, in some cases perhaps being prejudiced by being the owners of gas undertakings, and therefore not by any means certain in all cases to give the ratepayers the benefit of this new invention."* In ı886, Mr. H. G. Calcraft, Permanent Secretary of the Board of Trade from I886 to I893, testified as follows: "I think that the Board of Trade are always disposed to place great confidence in the decision arrived at by a corporation (municipality), or a local authority, in matters of this kind (the exercise of the provisional veto); and if after mature consideration they, as the representatives of the population, arrive at the conclusion that it is the best bargain that can be made, the Board of Trade would be inclined not to disagree

* Report of Committee on Electric Lighting Provisional Orders Bills, I $88_{3}$; q. I to 113 . 
with the corporation, unless there were some very strong reasons on public grounds against the proposal." Lord Bramwell queried: "But is it not possible that many individuals within the area might be very glad to have the light upon certain terms, but that they may not be able to persuade the local authority" (to let a company come in)? The answer came: "I suppose that may be the case; but I should have thought that the local authority was a good judge of what was to the interest of the locality generally." * In 1898 , Sir Courtenay Boyle, Permanent Secretary of the Board of Trade from I 893 to r9or, testified as follows: "We do not like doing it (overruling the provisional veto). Our principle is to trust the local authorities as representing the ratepayers and knowing what is best for their district. We are very often asked to do so on the ground that the local authorities are interested in gas, for instance, and for various other reasons. But, as a rule, we do not dispense with their consent. It is an extreme step to take; the Board of Trade have done it, but in a very few cases." $†$ In the same year, before another Committee, Sir Courtenay Boyle used these words: "We generally require it to be shown that there are special reasons; that the local authority are unnecessarily dilatory (in establishing

* Report of Lords Committee on the Electric Light Act, 1882, Amendment Bills, r886; q. 2265 and 2303.

$\dagger$ Report of Joint Committee on Electricity Generating Stations and Supply, 1898; q. I3, 78, and 79 . 


\section{MUNICIPAL OWNERSHIP IN GREAT BRITAIN}

a municipal plant), or (I do not like to use the phrase, 'dogs in the manger') that they will not do the thing themselves, and will not let other people do it." *

The testimony submitted in 1898 to the Joint Select Committee on Electricity Generating Stations and Supply was such that the Committee reported: "The Committee consider that the provisions of the Electric Lighting Act, I888, which require the (provisional) consent of the local authority as a condition precedent to the granting of a Provisional Order, should be amended. In their opinion, the local authority should be entitled to be heard before the Board of Trade, but should not have, so to speak, a provisional veto, only to be dispensed with in special cases by the Board of Trade." Four years after this report had been made, in June, I902, a deputation from the Institution of Electrical Engineers waited on Mr. Gerald Balfour, President of the Board, and asked that the recommendation of the Joint Select Committee of 1898 be given effect. Mr. Gerald Balfour stated that a Bill had been prepared to give effect to that recommendation. $\dagger$ But at the close of the session of $\mathrm{r}_{903}-4$ the Government had not yet summoned courage to introduce the measure into Parliament.

Before the Joint Select Committee on Municipal Trading, I900, the promoters of electrical under-

* Report of Select Committee on Telephones, 1898 ; q. 6792 to 6798 . † Garcke: Manual of Electrical Undertakings, 1903; p. 12 and 26. 
takings testified at length concerning the difficulty of Municipal Policy obtaining charters from the Board prevents Develop- of Trade. Mr. Sydney Morse, ment

Chairman of the Municipal Trading Committee of the London Chamber of Commerce, appeared on behalf of the London Chamber. As counsel to a large number of electrical undertakings of all kinds, he had a vast experience in the field under discussion. He said: "We have to prove the consent (of the local authority) to the Board of Trade; but although the Board of Trade have the power to dispense with the consent of the local authority, until last year they had never used it in any case; it was a mere question of grant or no grant. What I have found occurred was this with regard to the early days (I889) when electric lighting was first being put forward as really an experimental matter, that it was not difficult to get the consent, because it was difficult to find any one to take up the experiment, but that as the matter has become more of an assured success, so it has been more difficult. To get the consents nowadays, if you go to the smallest districts in the country, you have very onerous conditions put upon you as a condition for the consent. We also find where the authority owns the gas works that we frequently have this argument addressed to the Board of Trade: that the authority has invested a large sum in gas which might be endangered if electric lighting were allowed to be brought in by a 


\section{MUNICIPAL OWNERSHIP IN GREAT BRITAIN}

company; and that has prevailed." The Chairman queried: "Have you ever known a case where that argument has been publicly brought forward?" The reply was: "I had, in my own practice this year, a case in Wales where we applied for a Provisional Order under the Electric Lighting Acts, and the consent of the three local authorities where we desired the power was necessary; and they put that argument forward to the Board of Trade, and that argument prevailed." The Chairman continued: "Are you prepared to say that that was the argument upon which the Board of Trade acted?" The witness replied: "It was the only argument put forward by the opponents; they did not give their consent because they had these gas works. Of course, I cannot say what the Board of Trade actually had in their mind in deciding, but it was the only argument I knew of as being put forward against us." *

Lord Avebury, formerly Sir John Lubbock, and President of the Association of Chambers of Commerce, the Statistical Society, the Building Societies' Association, and Vice-President of the London Chamber of Commerce, was asked: "Would you say that the possession of a gas enterprise by a corporation would tend to prejudice them against the introduction of any electric light scheme?" $\mathrm{He}$ replied: "That is certainly my impression. From

* Report from the Joint Select Committee on Municipal Trading, 1900; q. 794 and 849 . 
circumstances, I have had a great deal to do with many new inventions, I may say all my life. I assisted - or rather I ought to say, impeded - my father in taking the first daguerreotype which was ever taken in this country, and from that day to this I have taken a great interest in all new inventions. I was chairman of the Edison Swan Company at one time, and certainly my impression was that we then had greater difficulties in dealing with municipalities which had invested in gas, because they thought we were introducing a competing light, and interfering with the value of their property. I believe this Committee have had before them evidence of the large number of Provisional Orders which have been taken out by municipalities and upon which nothing has been done. It is rather difficult to resist the conclusion that that has been done with a view of protecting their interest in gas; but, whatever the object may have been, there is no doubt that the effect has been very much to check the development of electric light and other electrical development in this country." *

Mr. W. L. Madgen cited a number of specific instances of the refusal of local authorities to give their consent to the Board of Trade issuing a Provisional Order to a company. He cited Macclesfield, saying: "It is stated frankly in the district,

* Report from the Joint Committee on Municipal Trading, I900; q. 1556 . 


\section{MUNICIPAL OWNERSHIP IN GREAT BRITAIN}

that being owners of the gas works they desire to keep out competition." * He next spoke of the corporation of Newbury which had obtained a charter in I892, but had failed to make any use of it. A company asked the corporation to sell the charter, whereupon the corporation asked the company to agree to charge for electricity rates that would not compete with the municipal gas plant's rates. A company notified Milton-next-Sittingbourne of its intention to apply for a Provisional Order. Thereupon the town clerk wrote: "My Council have directed me to state ... that as the gas works at Milton belong to the Council they will, at the proper time, take the necessary measures for opposing the proposed issue of a Provisional Order for supplying electricity for public or private lighting within their district." Mr. Madgen continued: "I think one of the hardest cases - I do not want to use a strong expression, but I feel inclined to say a flagrant case - is the Neath, Briton Ferry, and Aberavon. These in I89I had a joint population of 23,000 - in round figures now 24,000. It is a typical South Wales manufacturing district, which has not been very successful, and which is subject to great depression, as most of South Wales is. I feel confident from what I know of the district that it would be benefited by a cheap supply of electrical energy for in-

* In December, 1904, Macclesfield had 35,000 inhabitants, but was without electric light and street railways. 
dustrial and other purposes, and I should be willing to make the venture." Mr. Madgen then stated that in I 898 his company had been notified by the corporation of Neath that Mr. Madgen need not trouble to come down to Neath for any conference on the subject of the corporation assenting to the issue of a Provisional Order for electric lighting, "having regard to the very large amounts which they have expended on their gas undertaking ... and for various other reasons." In the following year, I899, Mr. Madgen's company asked the Board of Trade to dispense with the consent of Neath, Briton Ferry, and Aberavon. Thereupon, the Board of Trade checkmated the company by asking it to give evidence of a demand in the district for electric current. Mr. Madgen concluded with the words: "But that we were unable to do, as we find as a matter of experience, that the probable consumers are unwilling to commit themselves until the supply is actually available. That is an axiom among engineers, you cannot get consumers to commit themselves until they see the mains being laid." * Neath, population 14,000, obtained supply in 1903; but Briton Ferry, population 7000, and Aberavon, population 8000, were without supply in December, I904. Mr. A. A. C. Swinton, a member of the Council of the Institution of Electrical Engineers, a director in

* Report from the Joint Select Committee on Municipal Trading, 1900; 1659 to 1673 . 
several electric light companies, and consulting engineer to a number of local authorities, supplemented Mr. Madgen's evidence as to the way the Board of Trade plays into the hands of the local authorities. He cited the case of Weston-super-Mare, which had taken a Provisional Order in I89 I for the purpose of "blocking" the companies. Between I 89 I and I 898 several companies made futile efforts to buy the charter. "In I 897 some local people formed themselves into a company to apply to the Board of Trade to revoke the Order and obtain a further Order for their company. This application was made in 1898 , and was refused by the Board of Trade, who gave the local authority another year to consider the matter. The local authority again did nothing, and in the session of 1899 another application was made by the local people, and the Board of Trade then directed that a local inquiry should be held. Then the Urban Council came to the conclusion that they could no longer leave the matter in abeyance. Apparently they were aggrieved at the people who had forced them into this position, so they went and gave the Order to some totally distinct people. That is an instance of how these matters get stopped and arrested. After one or two experiences like that people will not take the trouble and devote their energies to trying to develop an industry where they are treated that way." *

\footnotetext{
* Report from the Joint Select Committee on Municipal Trading, I900; q. 1313 .
} 
The Board of Trade could have protected the persons who had brought before it the Weston-superMare case, by exercising its power to revoke the Weston charter for failure of the local authority to supply current within the period fixed in the charter, either two or three years.

The extent to which the Board of Trade's refusal to overrule the provisional veto of the local authorities has denied to the public the use of the electric current for power and lighting is indicated in the following facts. Rhondda, a city of I I 4,000 , thus far has kept out the electric light, even without going through the form of taking out a Provisional Order for "blocking" purposes. Tottenham, a part of Metropolitan London, with a population of I $6, \infty 00$, did not feel the necessity of taking out a "blocking" charter until 1902. In 1905, the Town Council was debating what to do with its charter - whether to use, to sell it, or to sit on it.

Ever since 1882, the Board of Trade has issued this notice for the guidance of applicants for Provisional Orders: "When application for Provisional

Administrative

Discrimination against Companies
Orders authorizing the supply of electricity within the district of any local authority are received by the Board of Trade from such local authority, and also from any other authority, company, or person, the Board of Trade will give the preference to the ap- 
plication of the local authority of the district in every case where, in the opinion of the Board of Trade, no special circumstances exist which render such preference inexpedient." * In $1883, \mathrm{Mr}$. T. H. Farrer, Permanent Secretary of the Board of Trade, testified that the local authority must show that it had a "bona fide" scheme for supplying the district. $\dagger$ Similar testimony was given in 1886 by Mr. H. G. Calcraft, Permanent Secretary of the Board of 'Trade; and in 1898 by Sir Courtenay Boyle, Permanent Secretary of the Board of Trade. $\neq$ Neither the Act of 1882 nor that of 1888 confers specifically upon the Board of Trade this power to discriminate against companies. One would presume, therefore, that the Board of Trade would exercise care to make sure of the good faith of a local authority asking for a charter in competition with a company; also, that the Board of Trade would exercise its power to revoke a charter when subsequent events had shown that the local authority had not acted in good faith when applying for a charter. But the examination of the facts shows that the Board of Trade took no pains to assure itself of the good faith of the local authorities, and that it refused to be convinced by subsequent events that local authorities had acted in bad faith.

* Traction and Transmission, 1902, p. 148. q. 12 .

$\dagger$ Report of Committee on Electric Ifighting, Provisional Bills, $188_{3}$;

$\ddagger$ Report from Select Committee on Telephones, I 898; q. 6794 to 6798 . 
Every Provisional Order granted to a local authority or to a company contains a clause authorizing the Board of Trade to revoke said charter if the holder thereof shall fail to supply current within a specified time, usually two or three years, in rare cases four years. At the close of 1904, supply was available under 294 Provisional Orders issued to local authorities. In 105 of those cases, five to sixteen years had elapsed between the issue of the Order and the supply of current.* On the other hand, supply was avail-

* Years elapsed between the issue of the Provisional Order and the supply of current, in the case of local authorities and of companies, respectively. Table constructed from data obtained from: Report by the Board of Trade respecting the Applications to and Proceedings of the Board of Trade under the Electric Lighting Act, 1882 to 1902, during the year 1902-03: Garcke: Manual of Electrical Undertakings, 1904; and The Electrician, supplements of January, 1905 .

Supply Available

\begin{tabular}{|c|c|c|}
\hline Years Elapsed & LOCAL AUTHORITIES & CoMpanies \\
\hline $\begin{array}{c}\text { o } \\
1 \\
2 \\
3 \\
4 \\
5 \\
6 \\
7 \\
8 \\
9 \\
10 \\
11 \\
12 \\
14 \\
16 \\
\text { Not ascertainable }\end{array}$ & $\begin{array}{r}9 \\
13 \\
45 \\
63 \\
51 \\
36 \\
22 \\
12 \\
9 \\
6 \\
13 \\
3 \\
2 \\
1 \\
1 \\
8\end{array}$ & $\begin{array}{r}36 \\
29 \\
35 \\
23 \\
7 \\
2\end{array}$ \\
\hline Total . • & 294 & I33 \\
\hline
\end{tabular}


able under I33 Provisional Orders issued to companies. In I 23 of those cases supply had been available within three years after the issue of the Order.

Again, at the close of 1904, no supply was available under 54 Provisional Orders issued to local authorities between I890 and 1900.* Acton, population 38,000 , had been sitting on its charter for fourteen years; Bacup, population 23,000, had been doing the same; Llanelly and Waterford, with populations of respectively 26,000 and 27,000 , had been sitting on their charters for thirteen years.

Finally, examination of the records reveals the fact that in the matter of revoking charters for nonuse, the Board of Trade administered the Electric

* No Supply Available

\begin{tabular}{|c|c|c|}
\hline Years Elapsed & Local Authorities & Companizs \\
\hline $\begin{array}{r}1 \\
2 \\
3 \\
4 \\
5 \\
6 \\
7 \\
8 \\
10 \\
12 \\
13 \\
14\end{array}$ & $\begin{array}{r}24 \\
29 \\
53 \\
31 \\
26 \\
13 \\
4 \\
1 \\
3 \\
1 \\
3 \\
3\end{array}$ & $\begin{array}{r}\text { II } \\
\text { 10 } \\
8 \\
4 \\
12\end{array}$ \\
\hline Total . . & 191 & 34 \\
\hline
\end{tabular}

1 This order was transferred to a local authority. 
Lighting Act in such way as to make one law for local authorities and another law for companies. At the close of 1903 , the Board of Trade had repealed 92 charters granted to companies. In five cases only had it allowed more than three years to elapse after the issue of the charter. On the other hand, at the close of 1903 , the Board of Trade had revoked only 20 charters issued to local authorities; and in I9 of those cases it had allowed more than three years to elapse.* Moreover, the eleven cases in which the Board of Trade revoked Provisional Orders issued to local authorities, and in force only from three years to six, occurred in I900 to I904, - that is, after the Joint Select Committee on Municipal Trading had taken evidence upon the way in which the Electric Lighting Acts were being administered. Previous to 1900 the Board of Trade had not revoked a local

* Years elapsed between the issue and the revocation of the charter in the case of companies and of local authorities, respectively.

\begin{tabular}{c|c|c}
\hline Years Elapsed & Local Authorities & Companies \\
\cline { 2 - 3 } I & 0 & 48 \\
2 & 0 & 33 \\
3 & 1 & 6 \\
4 & 4 & 1 \\
5 & 3 & 2 \\
6 & 3 & 1 \\
7 & 2 & 0 \\
8 & 4 & 1 \\
9 & 2 & 0 \\
10 & 1 & 0 \\
\hline TotaL . . & 20 & 92 \\
\hline
\end{tabular}


authority Provisional Order that had not been in force at least seven years.

The main reason why the local authorities have taken out so many Provisional Orders for the purpose of sitting on them has been the desire to reserve Municipal

"Orders" for the field until such time as they could "Blocking" Pur- plants. In this connection it should poses summon courage to install municipal plants. In this connection it should be remembered that even the largest cities, such as Glasgow, Birmingham, Liverpool, and Manchester, were still afraid to embark in electric lighting in 1892 , when there were in operation in the United States I454 central electric stations. There were also many other reasons that prevented the local authorities from using their charters. In $1895, \mathrm{Mr}$. W. H. Preece, Engineer-in-Chief to the British Post Office, who has a large practice as consulting engineer to local authorities, testified that the "fluctuating make-up of town councils is a very serious difficulty in the conduct by a municipality of a competitive business. I have the experience of electric lighting in mind. Large municipalities overcome the difficulty by forming small and strong committees and reëlecting the same chairman and thus maintain a kind of continuity of policy. Small corporations start with very large committees; they are constantly changing, and the result is that you find sometimes inability to agree upon the system to be used; some- 
times inability to agree upon the man to be employed to conduct the service; and it is incessant trouble and squabble." * Before the Joint Select Committee of I900, Mr. A. A. C. Swinton testified to a similar effect. He cited the instance of York, which had a population of 72,000 in 1891 . That city took out a charter in 1890 , but did not supply current until April, I900. Mr. Swinton also intimated that the influence upon the town councils of the owners of private gas plants was an element in the taking out of blocking charters. $\dagger$ Mr. W. L. Madgen said: "It is the feeling of electrical engineers that many of these Orders have been obtained for blocking purposes. In some cases the local authorities themselves own gas works, in other cases the (private) gas interests on the (town) council are strong." $\ddagger$

The following table shows that there were in the United States, in June, I902, 3620 central electric stations. Of those $35^{20}$ supplied current for

The United

Kingdom outstripped by the United States incandescent lighting and roo supplied current for power purposes or arc lighting only. Considering that in the first six months of 1902 there were opened I46 central electric stations, one will not

* Evidence taken before Committee on the Question of Adequacy of the Telephone Service in Local Areas, 1895; q. 2830 and 2831 .

$\dagger$ Report from Joint Select Committee on Municipal Trading, I900; I 3 IO to I 3 I 3 .

$\ddagger$ Report from Joint Select Committee on Municipal Trading, 1900; q. 1659 . 
do much violence to the facts in assuming that at the close of 1902 current for incandescent lighting was supplied by 3600 central electric stations. Further inspection of the table shows that the central electric stations were sufficient in number to average a station to every place of 25,000 or more inhabitants; one station each to 90 per cent of the places of 5000 and less than 25,000 inhabitants; and, finally, one station each to 77 per cent of the places of 1000 and less than 5000 inhabitants. This table understates the extent to which the places of 1000 and less then 25,000 inhabitants are supplied with central electric stations, for it exaggerates the number of such places. The federal census returns for 1900 give the population of only the incorporated villages, towns, and cities. They do not give the population of the unincorporated but populous places of New England. There have therefore been added to the federal census returns 621 New England townships with a population of 1000 and less than 5000, and 83 townships with a population of 5000 and less than 25,000 . Finally, this table makes no allowance for the fact that some of the 3620 stations supply current to surrounding cities, towns, and villages, so that the enumeration of places in which central stations are located does not fully represent the distribution of current. 
Electric Service in the United States and Great Britain*

\begin{tabular}{|c|c|c|c|c|}
\hline \multirow[b]{2}{*}{ Population } & \multicolumn{2}{|c|}{ United States } & \multicolumn{2}{|c|}{ UNITED KINGDOM } \\
\hline & $\begin{array}{c}\text { Number } \\
\text { of } \\
\text { Places }\end{array}$ & $\begin{array}{l}\text { Number of Cen- } \\
\text { tral Electric } \\
\text { Stations, } \\
\text { June, rgo2 }\end{array}$ & $\begin{array}{l}\text { Number } \\
\text { of } \\
\text { Places }\end{array}$ & $\begin{array}{l}\text { Number of } \\
\text { Places supplied } \\
\text { with Electric } \\
\text { Current, } \\
\text { December, } 1904\end{array}$ \\
\hline 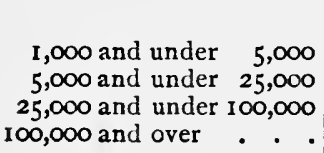 & $\begin{array}{r}3502 \\
755 \\
123 \\
38\end{array}$ & $\begin{aligned} & \% \\
& 2714=77.5 \\
& 675=89.4 \\
& 128 \\
& 103\end{aligned}$ & $\begin{array}{r}607 \\
613 \\
170 \\
66\end{array}$ & $\begin{aligned} 54 & =\% \\
195 & =31.8 \\
144 & =84.7 \\
64 & \end{aligned}$ \\
\hline & & 3620 & & 457 \\
\hline
\end{tabular}

Finally, it appears that at the close of I904, there were in the United Kingdom 363 central electric stations, $\uparrow$ which supplied current for incandescent lighting to 457 places; that no current was available in two places of 100,000 inhabitants; that none was available in 26 places of 25,000 and less than 100,000 inhabitants; and that current was available in only 9 per cent of the places of 1000 and less than 5000 people, and in only 31.8 per cent of the places of 5000 and less than 25,000 people. $\ddagger$ Had the United Kingdom,

* Bureau of the Census Bulletin, 5, 1903, Central Electric Light and Power Stations; Twelfth Census of the United States, I9oo, Vol. I, Population; The Electrician, supplements of January, 1905; Garcke: Manual of Electric Undertakings, 1904; and The Municipal Year Book of the United Kingdom, I904, edited by Robert Donald.

$\dagger$ The number of central electric stations supplying current had risen to 384 in January, 1906 .

$\mp$ The subjoined table gives in detail the number of places of various sizes, the total number of such places in which electricity is available, as well as the source of the electricity - that is, whether supplied by 
in 1904, been as well supplied with central electric stations as were the United States in 1902, current for incandescent lighting would have been available, not in 457 places, but in 1256 places. In fact, current would have been available in more than 1256 places, if allowance be made for the numerous populous places which exist in the socalled Rural Districts of England and Wales, but were not included in the foregoing enumeration. With very few exceptions, the enumeration is confined to boroughs and urban districts.

In striking contrast to the comparative absence of central electric stations in the United Kingdom is the great number of gas plants. In 1903 there were 1598 gas plants, of which number 888 were companies or by local authorities. It will be noticed that the companies have been confined very largely to cities of less than 25,000 inhabitants.

\begin{tabular}{|c|c|c|c|c|c|}
\hline \multirow{2}{*}{\multicolumn{2}{|c|}{ Population }} & \multirow{2}{*}{$\begin{array}{l}\text { Number of } \\
\text { Places }\end{array}$} & \multicolumn{2}{|c|}{$\begin{array}{l}\text { ELECTRICITY } \\
\text { SUPPLIED BY : }\end{array}$} & \multirow[b]{2}{*}{ TOTAL } \\
\hline & & & Companies & $\begin{array}{c}\text { Local } \\
\text { Authorities }\end{array}$ & \\
\hline$x, \infty 0$ and under & $5, \infty 00$ & 607 & 50 & 4 & 54 \\
\hline 5,000 and under & $10, \infty 00$ & 316 & 44 & 18 & 62 \\
\hline ro,ooo and under & 20,000 & 256 & 60 & 45 & 105 \\
\hline 20,000 and under & 25,000 & 41 & I3 & 15 & 28 \\
\hline 25,000 and under & 30,000 & $3^{8}$ & 4 & 22 & 26 \\
\hline $30, \infty 00$ and under & 40,000 & $5^{I}$ & ro & 33 & 43 \\
\hline 40,000 and under & 50,000 & 27 & 6 & 84 & 24 \\
\hline 50,000 and under & 60,000 & 18 & I & 15 & 16 \\
\hline 60,000 and under & 70,000 & 14 & 2 & II & 13 \\
\hline 70,000 and under & 80,000 & 7 & 2 & 5 & 7 \\
\hline 80,000 and under & 90,000 & 7 & I & 6 & 7 \\
\hline $90, \infty 00$ and under & 100,000 & 8 & 2 & 6 & 8 \\
\hline
\end{tabular}


non-statutory.* The non-statutory companies have found their way to the smallest places, as is shown by the fact that they average only 270 customers per plant, whereas the statutory companies average 4800 customers, and the municipal gas plants average 7700 customers. The average annual output per non-statutory gas plant is about I6,000,000 cubic feet, as against an average of $200,000,000$ for statutory companies; and $218,000,000$ cubic feet for municipal plants. The non-statutory gas plants are an eloquent testimony to the enterprise which the British capitalist displays when he is not paralyzed by the State or the Municipality.

At first blush it might seem that an explanation for the comparative absence of the electric light in the United Kingdom could be found in large part in the wide distribution of gas plants. This explanation seems all the more reasonable from the fact that in the United States, where electricity has become so common, there are few gas plants in the smaller places. $\dagger$ But examination of the facts shows that the explanation must be abandoned as untenable; for British capitalists would not be * "The Gas World" Year Book, 1904; and The Municipal Journal, January 8 and ${ }_{15}, 1904$.

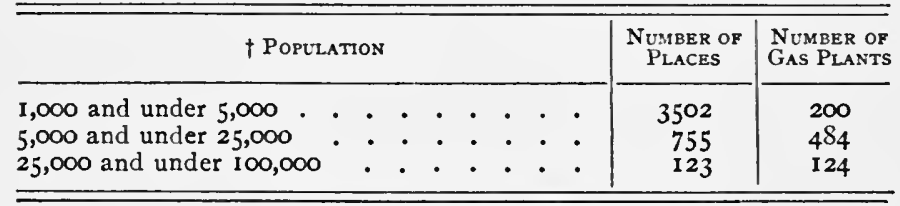


afraid to take up competition with gas light by means of the electric light, if they could enter the contest upon equal terms. At present those terms are very unequal. The non-statutory gas company operates under no restrictions whatever, whereas the electric light company operates under "the threat of purchase at the end of forty-two years," to use the phrase of Sir Courtenay Boyle, Permanent Secretary of the Board of Trade. Before a Select Committee Sir Courtenay Boyle testified that "if the electric light companies were relieved from the threat of purchase at the end of forty-two years, they would be probably able to compete with the non-statutory gas company." $\mathrm{He}$-added that it was his opinion that the extension of the life of franchises from forty-two years to sixty years would stimulate investment in electric lighting enterprises. Similar testimony was given by Mr. H. G. Harris, of the eminent engineering firm of Bramwell \& Harris.* It is scarcely necessary to add that the policy of compulsory sale at reconstruction value is not the only factor that is hampering the spread of central electric stations, and that a further serious hindrance is the fact that local authorities rarely give an unqualified assent to the Board of Trade issuing a charter to a company. The local authorities almost invariably sell their assent, when they

* Report of Committee on Electricity Generating Stations and Supply, 1898 ; q. 20.46, 2072, 2054, and 1157 . 
can be prevailed upon to grant it at all. The price exacted is either a cash price or some abatement on the part of the company of the rights which the Electric Lighting Acts nominally give the electric lighting companies.

But in spite of the foregoing handicaps, British capitalists have shown their eagerness to compete with the gas light by means of the electric light. Church Stretton is a village of $8 \mathrm{I} 6$ inhabitants, in which an electric light company is competing with a gas company. Electricity is available in 54 places which have a population of rooo to 5000 , and in 44 of these places there is gas supply. Again, electricity is available in 77 places of 5000 to II,000 inhabitants, and in 65 of those places there is gas supply.* Obviously, the spread of the electric light is not being arrested by the fear of capitalists to compete with the gas light by means of the electric light.

* "The Gas World" Year Book, I904; and Garcke: Manual of Electrical Undertakings, I904.

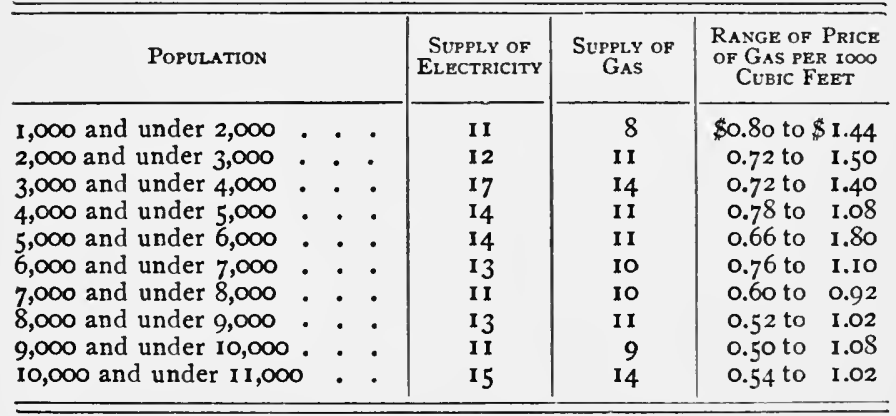




\section{CHAPTER XVI}

THE MUNICIPALITIES versus THE MANUFACTURER

IN 1883 the Board of Trade issued a notice "to guide applicants for charters under the Electric Lighting Act, 1882," as follows: "No monopoly is, under the Act or the Provisional Order, granted or intended to be granted to them; and should they neglect their duties in the district, or charge exorbitant prices, there is nothing to prevent the immediate grant of a license or Provisional Order to a competing set of undertakers within the same district. In the case of local authorities there will be not only competition to look to, but also public opinion. . . This paragraph is quoted at length, because there has been some misapprehension of the principles adopted, and because the Board of Trade wish it to be distinctly understood, both now and at all future times, under what conditions the present concessions are made, and thus to prevent any future claims to monopoly inconsistent with these conditions." *

The first section of the Electric Lighting Act,

* Report by the Board of Trade respecting the Applications to and Proceedings of the Board of Trade under the Electric Lighting Act, 1882, during the year $188_{3}$. 
I882, Amendment Act, I888, ends with the words: "The grant of authority to any Undertakers to supply electricity within any area, whether granted by license or by means of a Provisional Order, shall not in any way hinder or restrict the granting of a Provisional Order to the local authority, or to any other company or person within the same area."

In 1898 the Chairman of a Select Committee asked Sir Courtenay Boyle, Permanent Secretary of the Board of Trade: "Have you sanctioned competing schemes in London?" — "Yes, nearly every area in London has two lots of undertakers." * - "Have you sanctioned any competing schemes in the country?" - "Yes, we have in one instance; there is no reason why we should not do so. But our consent has not been applied for for competing undertakings as a rule. There is an instance in Newcastle." $\dagger$

In 1898 the large manufacturers of the district of Chesterfield formed a syndicate bearing the name of "The General Power Distribution Co.," and Wholesale Supply asked Parliament for authority to of Electricity prevented supply current to consumers in an area of 2 so square miles, including Sheffield and Nottingham. The region to be cov-

* In I904, in twelve Metropolitan Boroughs the local authority had a monopoly of supply; in two Boroughs there was competition between company and local authority; and in six Boroughs there were two or more competing companies.

+ Report of Committee on Electricity Generating Stations and Supply, 1898; q. $71,72,107,108,845$ to 849 and 875 . 
ered was one of the most important manufacturing districts in England; it had a population of $1, \infty 00, \infty 00$, but there were only I 546 firms or persons who were customers of electric current. Local authorities and companies had taken out charters, covering 66 square miles of the area in question, but only in 4.5 square miles was current available. These 4.5 square miles were the centre of Sheffield and the centre of Nottingham. In Shefficld a company had been supplying current since 1893 under restrictions that had been imposed by the corporation of Sheffield and were so onerous as to compel the company to charge ro cents per Board of Trade unit. In Nottingham the city had been supplying since I894; but in 1898 it had only 482 customers in a population of about 220,000. The city, which owned the gas plant, was charging 6 cents to 2 cents per unit. The General Power Distribution Bill fixed the maximum to be charged by the proposed company at 8 cents per unit for the first 200 hours in each quarter, and at 4 cents for the remainder of the quarter.*

The General Power Distribution Bill was referred to a Joint Select Committee of the Houses of Parliament; the Committee reported favorably, and thereupon the House of Lords passed it, with the amendment that in areas covered by charters

* Hansard's Parliamentary Debates, July 12, 1898. 
held by local authorities or by existing companies the General Power Distribution Co. should supply only to those individuals or firms which would take current in bulk for power, and not less than 10,000 units a year. The House of Lords, which habitually treats with most scrupulous regard all vested interests, held that the amendment in question did ample justice to all interests that had embarked in electric lighting in the earlier period - that is, before it had occurred to engineers to use for power purposes electricity generated and supplied on a large scale, and under most favorable conditions of economy. After the Bill had passed the House of Lords it was too late in the session to take it up in the House of Commons, and therefore leave was given to the promoters to proceed with the Bill in the next session, that of $1899 . *$

In January, 1899, shortly before the date upon which the House of Commons was to take up the Bill, the Lord Mayor of Manchester called a conference of the Municipal Corporations of Lancashire and Cheshire. The principal speaker, Alderman Higginbottom, Chairman of the Manchester Electric Lighting Committee, said: "If the report of the Select Committee of 1898 should ever be sanctioned by Parliament, it virtually meant that the recognized control - he laid emphasis on the 'recognized' - of the streets of their

* Hansard's Parliamentary Debates, July 22, I898. 
towns would be done away with.* In that case Parliament would practically declare that the monopoly in the supply of electricity which certain towns were supposed to have obtained from the Board of Trade existed only in the mind of the Board of Trade, and could be done away with by giving power to a company." $\dagger$ The conference resolved to oppose the General Power Distribution Bill in each House of Parliament, and at every stage, and to ask the coöperation of the Association of Municipal Corporations, as well as of the Association of Urban District Councils. In the year ending with March, I.898, the city of Sheffield had received on an average 7.8 cents per unit of electric current sold.

The Bill had the support of all the Chambers of Commerce in the area of 2 10 square miles, in-

* Report of Committee on Elcctricity Generating Stations and Supply, 1898; q. 1312, 1313, and 1372 . The following questions and answers passed between the witness, Mr. Alderman Higginbottom, and $\mathrm{Mr}$. Richards, of counsel for the companies. "Are you aware that the companies would lay mains under the superintendence and control of the corporation as the road authority?" "Yes." "Can you suggest, if that be so, any reason for its being more dangerous for the company to lay mains in a street than for the corporation to lay them?" "I do not know that it would be more dangerous."

Subsequently, Lord Balcarres, a member of the Committee, asked the witness: "I understand there is a Bill before Parliament . . . to which you objected on the general principle that your city dislikes private bodies opening streets. It is difficult, of course, to assume that the difficulty should be overcome in any way; but for the purposes of argument, assuming that the inconvenience of breaking up streets should be overcome, would Manchester object to the bill in question, which offers the principle accepted in London of limited competition for supplying electric light?" "Yes." "You would object to competition?" "We should object to competition."

$\dagger$ The Electric Engineer, January 13, 1899. 
cluding that of Sheffield. Some of the Urban District Councils were also in favor of the Bill, but they feared to support it, not daring to antagonize the Association of Municipal Corporations, whose good-will is of great value to the Association of Urban District Councils.* Not one Urban District Council was directly affected by the General Power Distribution Bill.

The House of Commons rejected the Bill by a vote of $\mathrm{I}_{4}$ to $\mathrm{I}^{2}$. The promoters had offered to accept an amendment excluding the company altogether from the areas of the Municipal Boroughs, and Mr. Stuart Wortley, the representative in Parliament of Sheffield, had signified his willingness to accept the compromise. But Sir James Woodhouse, $f$ "as the representative of the Association of Municipal Corporations," rejected the compromise and defeated the Bill. He said: "I desire as the representative of the Association of Municipal Corporations . . . to say that while I am quite ready to agree to the adjournment of the Debate, I should not be prepared to accede to the suggestion of the honorable Member for Sheffield (Mr. Stuart Wortley). It may be that the

* Report from the Joint Committee on Municipal Trading, 1900; q. 2594 ; Mr. D. H. Davies, Secretary of the Chesterfield Chamber of Commerce.

† Kt., cr. 1895 , M.P. (L.) Huddersfield, 1895 ; partner in J. P. and $\mathrm{H}$. Woodhouse, solicitors; Mayor of Hull, I891 ; Vice-President of Association of Municipal Corporations; Director of London City and Midland Bank, and of the Hull and Barnsley Railway Co.-Who's Who, 1905 . 
Municipalities in that particular area which the company touches might be satisfied with the exemption proposed by the honorable Member for Macclesfield (Mr. Bromley Davenport). But the Association of Municipal Corporations has taken up the matter not only in reference to a particular area, but also in regard to the great principle which underlies the Bill, and in respect to which the House is asked to pursue a retrograde policy. Reserving, therefore, all questions which arise in regard to the principle, I desire respectfully to say, as representing the entire body of Municipal Corporations, that we accept the adjournment but not the concession." *

The debate upon the Bill was instructive and is worthy of a brief review. Mr. Stuart Wortley, M.P. for Sheffield, and a director of the Great Municipal oppo- Central Railway, "as being intimately sition to Progress connected with the largest municipality which the Bill proposes to attack," moved the rejection of the Bill. He said: "The promoters are to be permitted, without any restriction whatever, and in the face of any amount of municipal opposition, to supply to manufacturers who are willing to take 10,000 units in the course of the year; in other words, they propose to take the cream of the consumers. . . . The fact that the other House has passed the Bill indicates that in the other House

* Hansard's Parliamentary Debates, March 3, 1899. 
there is not that unlimited respect and jealous watchfulness for the integrity and independence of municipal privileges which the House of Commons has always shown."

Mr. Bromley Davenport, who was in charge of the Bill, said that Mr. Stuart Wortley recently had said before the Chamber of Commerce: "He found himself obliged to admit that when he undertook, at the request of the corporation of Sheffield, to move the rejection of this Bill, he was not aware that the Chamber of Commerce had petitioned in its favor. He then went on pathetically to ask the Chamber of Commerce to understand that it is very difficult for a Parliamentary representative to resist the wishes of a municipality upon a matter so nearly affecting municipal interests." Mr. Davenport added: "We are asked to do this at the bidding and at the instigation of an Association of Municipal Corporations, scattered all over the country, some of whom are interested in gas undertakings . . . some of whom have electric supplies of their own at a cost to the consumer in every case higher than the maximum which is permitted under this Bill, and others of whom neither have, nor propose to have, any electric supply, but who combine with other corporations in a spirit of friendship and sympathy and brotherly affection when the sacred rights of municipal monopoly are threatened with the possibility of competition by private enter- 


\section{MUNICIPAL OWNERSHIP IN GREAT BRITAIN}

prise. . . The influence of the corporations has been very strong in this House, but I cannot refrain from saying that $I$ think it will be well if they are careful that that influence is not exercised unduly and excessively, as I think it has been in connection with this Bill. I do not mean the influence of an individual Municipality which is brought to bear upon its Parliamentary representative with respect to a measure of local interest. No one would object to that. . . B But I refer to the combined and concerted influence of the Association of Municipal Corporations which is brought to bear on an individual member of this House for the purpose almost of compelling him to vote for or against a Bill, which, as a matter of fact, possibly may not concern, even in the remotest degree, the constituency which he represents. That is the kind of influence which during the past few weeks has been brought to bear on honorable Members of this House, and, while I resent it, I recognize its force, and I recognize that it is likely enough to be successful."

Mr. Pickersgill seconded Mr. Stuart Wortley's motion with the words: "Lastly, the promoters of this Bill point to the experience of America. . . . I think the reference to the United States is singularly unfortunate, because it is notorious that the United States have become the prey of monopolist companies. It is because I believe the ultimate effect 
of this Bill must be to put large areas in England, interspersed among which are great industrial areas, under the control and at the mercy of a dividendearning company, that I very heartily second the amendment." Mr. Pickersgill had been in the Civil Service before he entered Parliament. He represented Bethnal Green, a Metropolitan (London) Borough of I 30,000 people, which enjoyed the distinction of having no electric light in this year 1905 .

Mr. C. P. Ritchie, President of the Board of Trade from I 895 to I900, said: "I came down to the House prepared to recommend the rejection of the Bill if it remained in the shape in which it was introduced. It seemed to me the principle of the Bill was a direct attack on the rights, privileges, and duties of Municipal Corporations, and whatever might have been the contingent advantages (to Great Britain's trade and industry) which might accrue in consequence of the passage of this Bill, I should have been bound to tell the House I did not think it would be wise in passing a Bill which practically set aside the existing law which adequately protects corporations in the exercise of the duties which they have to discharge. Any private Bill of that kind which sets aside rights which corporations have by law ought to be rejected. But, Sir, it seems to me that my honorable Friend (Mr. Davenport) who has spoken on behalf of this Bill has practically removed all the difficulties which 
are felt in connection with the second reading." It is scarcely necessary to add that Mr. Ritchie's argument contained several unsupportable assumptions. Parliament had not imposed on the local authorities the duty of supplying electric current; it merely had authorized local authorities to assume that duty. Moreover, the Government had not obliged local authorities to execute it, even after they had assumed it. Finally, Parliament had not promised exemption from competition to such local authorities as should elect to go into the business of supplying electric current.

The last speaker to the motion to reject the Bill, Mr. H. J. Wilson, a director of the Sheffield Smelting Co., who describes himself as "a Radical, strongly opposed to . . . any form of Protection," said: "Representing a constituency containing a very considerable number of small Urban Districts, I wish to be allowed to say that I have received very many protests against this Bill, expressive of an urgent desire that it should not be allowed to pass." *

Before the Select Committee on Municipal Trading, Mr. D. H. Davies, Secretary of the Chesterfield Chamber of Commerce, stated that the manufacturers Needs of the of the Chesterfield district were exManufacturers posed to the competition of German and other foreign manufacturers who had the * Hansard's Parliamentary Debates, March 3, 1899. 
advantage of relatively cheap electrical power obtained from central electric stations. Many Chesterfield manufacturers had sought to help themselves by installing their own electrical plants, but such plants could not supply as cheaply as central stations. He added that the Chesterfield corporation, which owned the local gas plant, had taken out an electric light charter in 1894 , but that in 1898 it had done nothing more than take two or three polls of the electors with a view to determining what to do with the charter. Speaking of the defeat of the General Power Distribution Bill, Mr. D. H. Davies said that the promoters had spent $\$ 50,000$ in Parliamentary fees in carrying the Bill to the Second Reading stage. He added: "It has been within my own experience that this kind of opposition to private enterprise has driven away capitalists, who have preferred to go into large enterprises of a similar character in foreign countries. They fear not merely the expenses of the fight in Parliament, and the risk of it, but they fear also the hostile attitude of the local authorities would be continued if they (the capitalists) should get charters from Parliament. Of course, the local authorities have great power (to harass companies) with their street by-laws, in one way or another, and that is a very serious consideration." *

In the year 1900, the Lancashire Electric Power

* Report from the Joint Select Committee on Municipal Trading, I9oo; q. 2586 to 2601 . 
Co. asked Parliament for authority to supply current in an area of rooo square miles in Lancashire. The company agreed to bind itself not to supply current within any local government area, whether municipal, urban, or rural, except with the express consent of the local authority concerned. The proposed scheme covered 129 local authorities and 182 townships, of which only 16 had central electric stations in operation, supplying current on a small scale to a small number. Manchester, for example, which had acquired a charter in I900, was serving 3228 customers in a population of 631,000 , the average customer having Ioo lamps of 8 candle power. Twenty-two other local authorities were merely sitting on their charters, having been thus engaged, in some instances, for not less than ten years. In 9I local authority districts no applications for Provisional Orders had been made. *

In 1900, six local authorities adjoining Manchester had transferred their electric lighting charters to that city, which was supplying current under those charters. The city had reduced the average charge per unit of current sold, from 10.26 cents in 1896 , to 6.48 cents in 1900 ; but it had not succeeded in reducing the cost of manufacture per unit sold, which had been 3.76 cents in 1896 , and was 3.68 cents in 1900. On the other hand, the maximum charges

* Hansard's Parliamentary Debates, March I, I900; Mr. SetonKarr; and Garcke: Manual of Electric Undertakings, Vol. V. 
of the proposed company were to be ro cents for the first 200 hours, 6 cents for the second 200 hours, and after that, 3 cents. The city of Manchester was anxious that still other adjoining local authorities should transfer their electric light charters to it. But if the Bill should pass, the Lancashire Power Co. would become a competitor of the city for the transfer of those charters.

On January 27, 1900, the Lord Mayor of Manchester convened a meeting of local authorities, to consider what steps should be taken to defeat the Second Reading of the Bill in the House of Commons. On May 4, r900, the Association of Municipal Corporations met to consider how they could influence the Select Committee to which had been referred the Lancashire Power Co. Bill.

In the House of Commons itself, the debate upon the Bill was opened by Mr. Macdona, who stated that he had voted against the General Power Distribution Co. Bill, in I899; but that he could see nothing objectionable in the Lancashire Power Bill, since that measure did not propose to interfere in the slightest degree with any local authority, municipal, urban, or rural, retaining the exclusive right to supply its constituents, should it so elect. He added: "There is a feeling in the country that the municipalities are organizing themselves into a gigantic monopoly with a view to strangling private enterprise in regard to the supply of electricity at 
the moment of its birth. ... There is also a feeling in the country that fair play has not been accorded to private commercial enterprise in this matter in its competition with the municipalities." After the opponents of the Bill had spoken, Mr. Macdona resumed the debate with the words, "Is it not clear from this that the kind of competition (now) objected to by the large towns is not competition within their own areas (which the Bill enables them to prevent), but competition in the supply to outside townships?"

The opponents of the Bill had no arguments and were compelled to have recourse to misleading statements and to tirades against "dividend-seeking" The Appeal to Prejudice companies. They addressed not the House of Commons, but the constituencies of that House, upon whose intelligence they set a low value indeed. Their object was to create among the constituencies such a feeling against the Bill that it would be difficult for Members of Parliament to vote for the Bill. Mr. Galloway, M.P. for Manchester and Director of the Great Eastern Railway, moved the rejection of the Bill. He caused Mr. Ritchie, President of the Board of Trade, to jump to his feet, with the words: "That is a most garbled report of what I said (in I899), and I think the quotation is most unjustifiable." Mr. Galloway continued the debate with the statement that the Bill proposed a sliding scale of price and 
dividend, under which, starting from a maximum price for current and a maximum cumulative dividend of ro per cent, the company should be allowed to increase that maximum dividend by one per cent every time it reduced its charge for current by five per cent.* "How such a scheme is going to benefit the ratepayers or the communities who require electricity, I entirely fail to see. .. The great point is that by the company taking these compulsory powers (to break up streets for the purpose of laying mains) by Act of Parliament, the corporations themselves will not derive one penny of profit or any advantage whatever from the breaking up of their streets."

Sir James T. Woodhouse, the representative in the House of Commons of the Association of $\mathrm{Mu}$ nicipal Corporations, seconded the motion to reject the Bill. He said, "The promoters of the measure were not a public authority seeking public rights at the hands of the House of Commons, but a body of private speculators primarily desirous of pecuniary gain, but presenting their case as one of public policy and as satisfying a great and pressing public demand."

Mr. Broadhurst, M.P. for Leicester, said: "The Bill is not a philanthropic measure, but the venture

* The Act as passed provides for a dividend of 8 per cent and " an additional 1.25 per cent reduction in price for every 0.25 per cent increase of dividend above 8 per cent in respect of every 5 per cent charged below the maximum price allowed by the Act." 
of a body of private persons for the sake of gain. It was a sort of Chartered Company scheme by which the promoters saw a good opportunity to obtain certain rights which at present belong to other people, and if the Bill were to be passed, the small municipalities of the country would be handed over to the hands of persons whose only idea was to accumulate vast fortunes out of the necessities of the people." Mr. Broadhurst represented Leicester, a city of 224,000 people. The city, which owned the gas works, had begun to supply electric current in I894. In July, I900, the city had 793 electric current customers, who used on an average 70 lamps of 8 candle power, and paid 8.44 cents per unit of current.

Sir William Vernon Harcourt replied: "I do not altogether share my honorable Friend's objections to great enterprises being carried on through private sources. That was a question which occupied fifty or sixty years ago the attention of this country, and that was at the time of the commencement of the great railway interest. That question was decided by the wisdom of the great statesman, Sir Robert Peel. We know that Sir Robert was much attacked at that time for throwing the railway enterprise of this country into private hands, and not adopting the system so largely followed on the Continent. I look forward to this question of electricity and electric supply as the great question of the future, and it is from that point of view that I wish to refer to 
the subject. ... No man can say to-day what part electricity may not play in the industry of the country, and that is a point which the House of Commons should keep in mind." He concluded with the statement that Parliament dealt with the great questions of railways by laying down general rules under the observance of which private enterprise was given full scope. Parliament did not ask promoters to take their chances with Private Bill Committees - nor, he might have added, with a Board of Trade that since 1870 never has missed a chance to throw the great weight of its authority on the side of municipal activity and against private enterprise.

Mr. Ritchie, President of the Board of Trade, said: "It is true, I think, that the electrical enterprise of this country is in an exceedingly backward condition; it is inferior with regard to light, and certainly with regard to the conveyance of power to many European countries, and it is greatly inferior to the United States and Canada. It may almost be said that there are villages in the United States which are in possession of advantages in connection with electricity which some of our largest towns do not possess. It cannot be doubted that there is a great demand for something to be done. ... It must be remembered that it was the Act of $\mathrm{I} 882$ which more than anything else had delayed and hampered the development of electrical supply." 
This statement came from the man who was unwilling in 1900 , as he had been in 1899 , that power companies should have the right to compete with the local authorities in their areas in furnishing current at wholesale for power purposes, "whatever might be the contingent advantages (to British industry, hard pressed by the competing industries of Belgium and Germany)."

The Lancashire Power Bill was passed after Manchester, Salford, Bootle, and Stockport had persuaded the Committee of the House of Lords to insert a clause to the effect that the cities in question should have no power to take current from the company, even if they should, at some future date, change their minds and desire to take current. For the rest, the company may sell current in bulk to local authorities and to companies holding Provisional Orders. The company may itself obtain charters for local areas, if it can persuade the local authorities to give consent, or can persuade the Board of Trade to overrule local authorities that are unreasonably withholding consent.

The Lancashire Company's area is rooo square miles. In it are a large number of collieries, engineering works, cotton mills, and numerous other Parliamentary industries which have in use steam Grant rendered engines aggregating over I,000,000 Nugatory horse power. The directorate is very strong, being composed of the so-called "Edmund- 
son group," who have been very successful with the lighting of a number of small-sized and moderatesized towns. The company has an authorized capital of $\$ 15,000,000$, with power to borrow $\$ 5, \infty 00,000$. But the difficulty of obtaining Provisional Orders, which would permit the company to supply current direct to consumers, as well as the difficulty of inducing local authorities to take current in bulk, have thus far proven all but insurmountable. In I900, the company had contemplated the erection of four generating stations. In February, I905, the company was completing its first station, which is to contain initial plant capable of supplying about 6000 horse power.*

Among the Power Acts passed in I9or, was the Act of the Derbyshire and Nottinghamshire Electric Power Co. That Act was a revival of the General Power Distribution Bill which had been defeated in 1899 . The promoters stated that they represented manufacturers who had invested in their enterprises $\$ \mathrm{r}, 000,000,000$. There was opposition from the local authorities of Derby, Mansfield, Chesterfield, Warsop, and various urban districts. But on the whole the opposition to this Bill was less determined than that to the other Bills passed in I90I, "apparently because of the prevalent impression that nothing but a comprehensive scheme for

* Garcke: Manual of Electrical Undertakings, Vol. VI; and The Engineering Magazine, February, 1905. 
supplying cheap power could restore some of the decaying industries which have been domiciled in this district for a very long period." * The only points really fought involved the extent of the protection to be given to towns having municipal electric plants. The company will erect four generating stations, to supply an area of 1570 square miles. It has power to raise $\$ 9,000,000$ by the issue of stock, with the power to borrow $\$ 3,000,000$.

The most important power scheme authorized in I90I was that of the Yorkshire Electric Power Co., covering the whole of the Smith Yorkshire manufacturing and colliery districts, an area of I800 square miles. The promoters of the Bill numbered 63 , and they included a number of the leading representatives of industry, who intended themselves to become large consumers. The list of the promoters contained such names as Armitage, Blackhouse, Baines, Brotherton, Crawshag, Fox, Green, and Holliday. The corporations of Leeds, Bradford, and Sheffield made a stubborn fight to prevent the company obtaining right of way for its underground mains through their respective areas for the purpose of reaching certain other areas that wished to be supplied. As the boundaries of Leeds and Bradford touch, this opposition, if successful, would have meant the creation of an island 18 miles in length in the centre of the area of supply, and that * Garcke: Manual of Electric Undertakings, Vol. VI, p. 6. 
would have placed most serious engineering difficulties in the way of the economical operation of the four proposed generating stations. The prohibition to pass through the territory of Sheffield would have prevented the Yorkshire Co. from joining its supply with that from the Derbyshire and Nottinghamshire Co.'s mains. Of course, the Yorkshire Co. did not propose to supply in Bradford, Leeds, or Sheffield. Moreover, it proposed that the city authorities in question should select the route which the mains should follow, and should, at the expense of the company, themselves lay the mains. The local authorities talked the usual "moonshine" about losing control of the streets - to use a phrase employed in 1886 by Lord Bramwell, a member of the Lords Committee of that year* - but, as a matter of fact, they were actuated solely by the desire to cripple the Yorkshire Co. They feared that the power companies would undersell the municipal electric light plants; and that the manufacturers located within the city limits would not long put up with having to pay more for power and light than was paid by the manufacturers located outside of the city limits. Their fears were well grounded.

* Report of Lords Committee on the Electric Light Act, 1882, Amendment Bills, 1886; q. 1805. Lord Bramwell to Sir George Morrison, Town Clerk of Leeds: "You said that the electric light companies come to Parliament for certain powers, and therefore they ought to give a quid pro quo. I quite agree, if they come to Parliament for certain powers, Parliament is bound to make the best bargain that it can with them; but as to the breaking up of the streets, I believe it is all moonshine; the better reason is that Parliament can do it." 
To-day power companies are "offering prices for a combined lighting and power supply such as the municipalities have not even thought of - for instance, in the neighborhood of Manchester, contracts are being made by a power company at prices varying between I cent and I.5 cents per unit." * In 1903, Manchester was charging for power, from 3.75 cents to 2 cents.

In the course of the deliberations of Parliament upon the policy to be adopted by Parliament in the matter of power companies, the Board of Trade conBoard of Trade tinued the policy of throwing its great sides with

Municipalities weight on the side of the municipalities and against private enterprise. In I898, before a Select Committee of Parliament, Sir Courtenay Boyle, Permanent Secretary of the Board of 'Trade from I 893 to I9oI, argued in favor of the policy of compulsory sale of these great power undertakings at structural value. Sir Courtenay Boyle took a decided stand on this question of public policy, though he himself admitted that liability to compulsory sale would restrict private enterprise "to a certain extent, but only to a certain extent." He also admitted that "he was not quite sure" that the privilege of purchase at structural value would "be very valuable to the local authorities," and that he himself had no clear notion how

* The Municipal Journal, June 30, 1905; report of an address by Mr. Hodgson, Deputy Chairman Salford Electricity Committee. 
to overcome the difficulty arising from the fact that it would not be expedient or practicable to give any one local authority the power to purchase an undertaking covering the areas of many municipalities." *

In the period from I900 to 1904 , twenty-four supply companies were authorized. The terms upon which the charters have been granted have depended mainly upon the degree of opposition exercised by the local authorities concerned. The less favorable terms are known as the "Lancashire" terms. They authorize the power company to supply in bulk to local authorities and companies holding Provisional Orders, and to supply directly to consumers in case the power company can acquire a local Provisional Order. The more favorable terms are known as "South Wales" terms. They authorize the power company to supply energy in bulk to "authorized distributers," - that is, holders of Provisional Orders,and to supply current directly to any person for power purposes, and current for lighting any premises on some part of which the power is utilized, provided that in both cases in a local area where a local authority or a company holds a charter, the consent of the holder of that charter is first obtained. If such consent is withheld, the Board of Trade may dispense with it, if, in the opinion of that body, the holder

\footnotetext{
* Report of Committee on Electricity Generating Stations and Supply, I898; q. 2066 to 2069.
} 
of the charter is not willing and in a position to give the requisite supply to the power user upon reasonable terms and within a reasonable time.*

All power companies that obtain Provisional Orders authorizing them to supply current directly to consumers, are, of course, subject to the provision which gives the local authority concerned power to purchase, at structural value at the end of forty-two years, the distributing mains and other property lying within the local authority's area.

In the years 1903 to 1905 , the Government three times introduced into Parliament, and three times withdrew, the so-called Electricity Supply Bill, a parliament help- measure designed to give effect to the less before the recommendations of the Lords ComMunicipalities mittee of 1898 on Electricity Generating Stations and Supply. The Bill authorized the Board of Trade to issue Provisional Orders to power companies for supplying current in bulk to "authorized distributers" - that is, to companies or local authorities holding Provisional Orders. It repealed the provisional veto of local authorities in the matter of Provisional Orders for electric lighting, as well as for supply of current in bulk. It gave the Board of Trade discretionary power to insert or to omit from Provisional Orders for

* Report from Joint Select Committee on Municipal Trading, ı 900 ; q. 2346; Mr. A. Bonham-Carter, Referee of Private Bills, House of Commons, 1866 to 1903 . 
supply in bulk provision for compulsory purchase. It protected the consumer by providing that at the end of every five-year period any twenty consumers could petition the Board of Trade to fix new maximum charges for the supply of current; and upon such petition the Board of Trade was to have power to fix new rates, if it deemed the existing rates unreasonable. In I903, the Bill did not get beyond the first Reading in the House of Lords. In the following year it passed in the House of Lords, but the issue of The Electrician, a weekly newspaper, which announced that the Bill had passed in the House of Lords, announced also that the Government had withdrawn the Bill. In I905 the Bill was once more accepted by the Lords. But the Government refused to try to put it through the Commons, on the ground that it was a measure "not uncontroversial," and that consequently, there was not time to take it up. *

At the close of the Session of I905, Parliament had not amended the Tramway Act, I870, the Electric Lighting Act, I888, or the Light Railways Act, I896.

The reason why the Government did not care, in I905, to take up in the House of Commons a controversial electricity supply Bill is explained by the fate of the Administrative County of London Electric Power Bill, which passed the House of Lords, but

* The Municipal Journal, July 21, 1905. 


\section{MUNICIPAL OWNERSHIP IN GREAT BRITAIN}

was talked to death in the House of Commons. Sixteen Boroughs and thirteen companies hold Provisional Orders for Metropolitan London. To protect those authorized distributers, the Lords inserted in the Bill the provision that the power company should not supply within an area held by an existing authorized distributer, unless it was proved to the satisfaction of the Board of Trade that it could supply more cheaply; and then the existing authorized distributer was to have the option of taking the current required from the power company at a price which would leave the authorized distributer a reasonable profit. This clause caused most of the companies, if not all of them, and some of the Boroughs, to withdraw their opposition to the Bill. But it did not modify the opposition of the London County Council, which hoped at some future date to obtain power from Parliament to buy out the existing authorized distributers and acquire a monopoly of supplying electricity in Metropolitan London. For the protection of the consumer the Bill provided that the company should not pay its standard dividend unless its average receipts per unit of current should be I.5 cents. For every I.25 per cent by which the average receipts per unit were below 1.5 cents, the dividend might be increased by $\frac{1}{8}$ of I per cent. On the other hand, for every I.25 per cent by which the average price per unit of current sold exceeded $\mathbf{1} .5$ 
cents, the dividend payable was to be reduced by $\frac{1}{8}$ of I per cent, so that the company would not be allowed to pay any dividend if its average receipts per unit should be 2.125 cents. Moreover, at the expiry of each period of five years, the Board of Trade, upon the petition of twenty consumers, was to have the right to revise the maximum charges to be made. The Bill also contained a clause authorizing compulsory purchase by some public body at the end of forty-two years, on the basis of the audited capital expenditure, less allowance for depreciation.

Owing to the proposed adoption of large turbo. units the estimated capital investment per kilowatt to be installed was $\$ 42.50$. The actual average investment per kilowatt installed by the authorized distributers had been $\$ 252.50$; which explained why the average charge for power made by those distributers was 3.88 cents per unit.

The Bill had the support of the Great Eastern Railway Co., the London and India Docks, and the Surrey Commercial Docks, employing in all 100,000 persons. The railway companies declared that the possibility of their obtaining electrical energy at the proper price without their having to install their own plants, would hasten the electrification of that part of their railway plant which served the suburban communities. That, in turn, would make it possible to supply a cheaper, more rapid, and more extensive suburban service. 
Before the Select Committee of the House of Lords, Mr. Alderman Bussey, who represented the Borough of Poplar (I69,000 people), stated that Poplar would not accept current from a company at a rate lower than that at which the Poplar municipal plant could generate. The Borough of Westminster ( 186,000 people) also objected to becoming a "mere distributer" of current generated by a company. At the time of these statements the "works cost" of generating current in the eleven municipal plants was $\$ 987,000$, whereas the company was prepared to furnish the same amount of current for $\$ 667,000$, or 68 per cent.

The Bill was talked to death in the House of Commons, the promoters of the Bill not being given a chance to introduce a resolution authorizing them to take the measure up in the next Session. If, therefore, the promoters should desire to take up the Bill in 1906, they will have to begin all over that is, incur again the enormous expense of promoting their Bill before Committees of the Lords and the Commons. That expense, at a conservative estimate, will be not less than $\$ 50,000 *$

The level of the debate in the House of Commons is illustrated by the argument of Mr. John Burns,

* Garcke: Manual of Electrical Undertakings, 1904. It cost the South Wales Electrical Power Distribution Co. no less than $\$ 78,6$ I 5 in parliamentary fees to obtain two Special Acts. In addition, the Company paid $\$ 150,000$ in its own shares and debenture stock for "remuneration for obtaining its Acts, and preliminary work in flotation of the Company." 
one of the representatives of the London County Council. Mr. Burns argued that, by cheapening the production of electric current, the power company would increase the number of the unemployed.*

In June, I904, when the Government's Supply of Electricity Bill passed the second reading in the House of Lords, The Municipal Journal wrote: "So far as we know, no journal except our own has yet drawn attention to the dangerous abrogation of principle which is at the back of this measure. In the words of a well-wisher of the Bill, 'the largest cities and towns have already their electricity systems and, consequently, they have no reason to oppose the Bill. The others are too small to be taken any notice of.' So far everything has gone as this prediction indicated. There has been no opposition to the Bill, and the Company promoters whose interests it is intended to serve have lain low, hoping that the measure will be through Parliament before anybody knows anything of its provisions.... Corporations already possessing their electricity supplies are entirely wrong in assuming that the measure does not affect them. It will affect them very materially. When in the course of time urban districts are able to obtain their current at about half the price at which municipal corporations can manufacture it, the consumers in the large cities and towns will no longer be content to pay the larger figure.

\footnotetext{
* Engineering, August Ir, 1905.
} 
They will want to be placed on equal terms with the outside districts, and they will have justice at their backs. What then will become of our city and towns (i.e. municipal) electricity supply systems?" *

About a year later, in May, 1905, this same journal wrote: "The question of depreciation has reached an acute stage with many of the (municipal) underFinancial Weak - takings which have been at work ness of Municipal about ten years. It was the custom Undertakings of consulting engineers in those days to install a number of comparatively small generating sets. These are to-day out of date, and out of place, for they not only are wasteful in the space occupied, and the quantity of oil, of steam, and magnitude of repairs, but even at their most economical loads, their efficiency falls far short of what can be obtained from plants of modern design. They are an admitted incubus to an undertaking, an enigma to the engineer who is unlucky enough to have them on his hands. The problem is what can be done with them. To scrap or discard these 'toys' is a luxury few places can afford, inasmuch as the difference between their original cost and the amount written off by the proportion of the annual sinking fund payments is so large that it would be difficult to obtain sanction from a (municipal council) committee to place it against the income in any one year. Yet this is the only course open where there is no

* The Municipal Journal, June I7, 1904. 
reserve or depreciation fund to meet the extraordinary expenditure. Moreover, the only way in which the competition of the bulk power supply companies can be met is by immediate and large reductions in cost of production. . . . It cannot be urged too strongly, or reiterated too frequently, that the real problem facing municipal electrical undertakings is a financial one, and a sound and well-considered policy should be decided upon, and consistently adhered to. The time has come when a few large generating sets of good efficiency tell above all things in the race for success, and these can only be obtained if the future has been foreseen and there is sufficient capital to cover expenses." *

* The Municipal Journal, May 5, 1905. 


\section{CHAPTER XVII}

THE MUNICIPALITIES versus THE WAGE-EARNERS

ThE foregoing review has shown that, if the United Kingdom were as well supplied with street railways and central electric stations as are the United States, British Electrical it would have fully four times the Industries out- mileage of street railway track that it stripped actually has and at least three times the number of central electric stations. Furthermore, a review of the telephone industry in the United Kingdom - which has been paralyzed by the British Government, largely from the desire to protect the state telegraph system against competition from the telephone - would show that the people of the United Kingdom make only one-fifth to onefourth the use of the telephone that the people of the United States make. Finally, a review of the industries devoted to the manufacture of electrical apparatus and supplies would show that the paralysis of those industries has been proportionate to the paralysis of the street railway, central electric station, and telephone industries. 
For example, before the first Select Committee on Municipal Trading, I900, Mr. Garcke stated that the four or five leading English firms manufacturing electrical apparatus and supplies had a subscribed capital of only $\$ 10,000,000$, and were declaring average dividends of 4.5 per cent to 6 per cent only. On the other hand, the four or five leading German firms had a subscribed capital of $\$ 65,000,000$, and were declaring dividends of Io per cent to 25 per cent. The witness added: "During the whole of this time English electrical manufacturers have been hungering for orders for electrical machinery, but they have not been able to establish large factories because they have not known what was to be the development of the industry, whether it was coming on or not. Meanwhile foreign electrical manufacturers who have had the benefit of supplying electric lighting for many years past, and the Americans likewise, have been able to establish large factories and to go in for all kinds of experimental work, and in fact to develop the industry in every way. So that when pressure was afterward put upon the local authorities to go on with their Provisional Orders or drop them or transfer them to companies, and they finally decided to go on with them, the English manufacturing companies were not in so good a position as the foreign manufacturers. The result is that a very large proportion of the electrical apparatus is now being imported from America. . . . 
A large proportion of our rails comes from America, and the cars likewise." *

In explanation of the importation of rails, it should be added that the street railway demands a special rail. The large market in the United States has led to the erection of rolling mills devoted exclusively to the manufacture of street railway rails. Those mills work much more cheaply than their English competitors, whom the small British market compels to treat the manufacture of street railway rails as a mere side issue.

Some indication of the extent to which the demand for labor has been restricted in Great Britain by the Loss of Employ- practice and the spirit of municipal ment to Wage- ownership is to be obtained by comearners paring the number of wage-earners in the electrical industries of Great Britain and of the United States.

There were in the United States, in 1902, 3620 central electric light stations, employing 30,326 persons, or an average of 8 persons per station. In January, 1906, there were in the United Kingdom 384 central electric stations. $\dagger$ If, on that date, the United Kingdom had been as well supplied with central electric stations as were the United States in I902, the number of central electric stations would have been, not 384 , but I260. Eight hundred and

* Report from the Joint Select Committee on Municipal Trading, I900; q. I I 80 and I $8 \mathrm{I}$.

† The Electrician, January 12, 19, 26 and February 2, 1906. 
seventy-six additional central electric stations, on the supposition of the employment of 8 persons per station, would have given employment to 7000 additional persons.

In 1902, there were in the United States 21,302 miles of street railway track, giving rise to the employment, on the average, of 6.5 persons per mile of track. Had the urban population of the United Kingdom, in January, I9o6, been as well supplied with electric street railways as was the urban population of the United States in I902, the United Kingdom would have had, not 3040 miles of electric street railway track,* but I4,000 miles. Eleven thousand additional miles of electric street railway track, on the supposition of an average of 6.5 persons per mile, would have given employment to 7 I, 500 additional persons.

There were in the United States, in I900, I05I villages, towns, and cities with a population of 4000 people, or more. Of these places, not less than 1002 were supplied with telephone exchanges. The latter gave employment to the great bulk of the $78,75^{2}$

*The Electrician, January 12, 19, 26, and February 2, 1906.

Electric Street Railways in the United Kingdom

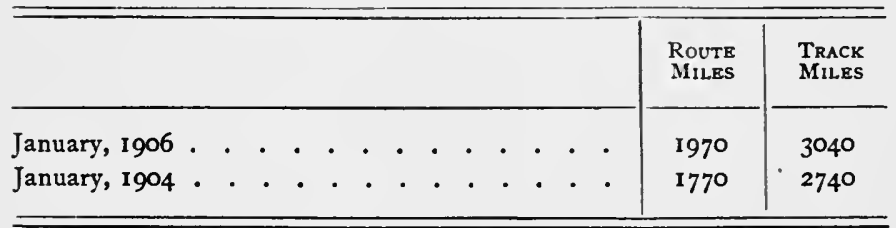


persons employed in the telephone business in I902.* On the other hand, there were in the United Kingdom in I90I about 950 places with a population of 4000 or more people. Had the United Kingdom, in 1905, made as much use of the telephone as the United States had made in 1902, it would have had at least 50,000 persons employed in the telephone business. As a matter of fact, there were in 1905 only I 3,000 persons employed in the telephone business in the United Kingdom. $\dagger$

The figures appertaining to the telephone business in the United Kingdom are included in this discussion for the reason that the British Government for years deliberately paralyzed the telephone business for the purpose of protecting the state telegraphs from competition from the telephone. When the British Government became ready to withdraw its paralyzing hand, the municipalities prevented that withdrawal. This matter will be set forth at length in a volume soon to be published.

It has been shown, in the foregoing discussion, that, had it not been for the paralysis of industry inflicted by the spirit of municipal ownership and state ownership, in the period from I870 to I905, there might have been employed in gainful occupations, in the United Kingdom, in 1905 , some I I 5,000 more people than were actually so employed. In the

* United States Census Bulletin, November 17, 1905.

†Hansard's Parliamentary Deba!es, May 3, I905; p. 860; Mr. Keir Hardie. 
aforesaid period, about the same number of people have been compelled to emigrate from the United Kingdom, or to remain in, or join, the ranks of the unemployed. But that is not all. Had the electric lighting industry, the electricity power supply industry, the electric street railway industry, and the telephone industry not been paralyzed from i 870 to the present day, the industry of manufacturing electrical machinery and apparatus would be much greater than it is. It would have a larger domestic market in the United Kingdom itself; and it would be in a much better position to compete with the United States and Germany in supplying the international markets of Europe, South America, and Australasia. In I90I, there were engaged in the United Kingdom in the manufacture of electrical apparatus a total of 54,600 persons. Had the United Kingdom not entered upon the policy of Municipal Ownership in 1870 , the aforesaid total of 54,600 persons would have been very much larger.*

The foregoing figures do not tell the whole story. Some industries, such as the production of pure copper and aluminum, of caustic soda, and of bleaching

* The Census of the United Kingdom for I9or shows:-

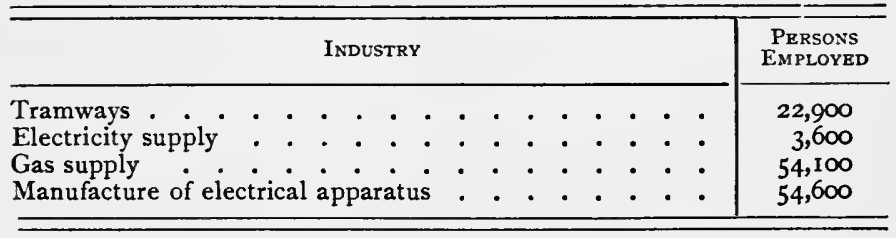




\section{$30 t$ MUNICIPAL OWNERSHIP IN GREAT BRITAIN}

powder, are now almost exclusively electrical industries. Precisely in so far as Great Britain's supply of cheap electric current is inferior to that of Germany, just so far is Great Britain handicapped in producing the aforesaid products of industry for the purpose of sale in the world's markets. Again, in Germany the belt and shaft are rapidly disappearing from the factories, and machine tools, looms, etc., are being driven by separate electric motors.* All of these things tell in the struggle between England and Germany in the world's markets. The significance of that struggle lies in the fact that from one-third to one-half of the population of Great Britain depends for its daily bread upon the export of British manufactures. Broadly speaking, there can be no increase of the population in Great Britain, except there be a concurrent increase in the export of British manufactures.

The growth of the electrical industries would not only increase the demand for labor, but would also improve vastly the health and the comfort of the wageIndirect Harm to earner. The growth of street railBritish Wage- ways would enable the wage-earner earners

to escape from the congested districts. But the electric power supply, in conjunction with the telephone, would help the wage-earner still more by promoting the transfer of manufacturing establish-

* Report from Select Committee on Electricity Generating Stations and Supply, 1898; q. 926; Mr. J. Swinburne; and Engineering, January 20, 1905. 
ments from the centres of the cities to the suburbs, and even to the rural belt beyond the suburbs. In this connection it is instructive to note that the recent Royal Commission on London Traffic reports that, "The provision of cheap electrical power is a most potent factor in the direction of the decentralization of manufactories, and we think that every facility, both legislative and municipal, should be given to that end." * A recent report from one of the British Consuls stationed in Germany states that the supply of power from large central stations to more or less isolated industrial establishments situated in rural districts at considerable distances is on the increase in Germany.

In the remarkably prophetic and profoundly penetrating address that the late Marquis of Salisbury gave in 1890 , upon the occasion of the first annual dinner of the Institution of Electrical Engineers, in London, he stated, in terms as philosophic as they were eloquent, the enormous and far-reaching results that would probably ensue from the use of electricity as an agent for the transmission of power, and the great industrial and social benefits that might be expected from development in that direction. The Marquis of Salisbury was Prime Minister from I 886 to 1892 , and from 1895 to 1902 ; but either he was unable or he deemed it politically inexpedient

* Report of the Royal Commission on the Means of Locomotion and Transport in London, I905; p. $9 \mathrm{r}$. 
to impress upon British legislation his enlightened views regarding the service rendered to society in the past by private enterprise, and the advantages likely to accrue to society in the future from the application of individual initiative to the exploitation of the new force, electricity. The British voter is caught in the meshes of the specious argument that the profits to be made in the so-called public service industries that make use of the streets belong to the general public and not to mere "private speculators." He has been hypnotized by the words of Mr. Joseph Chamberlain: "I distinctly hold that all monopolies which are sustained in any way by the State ought to be in the hands of the representatives of the people; by the representative authority should they be administered, and to them should their profits go, and not to private speculators." 


\section{CHAPTER XVIII}

\section{THE MUNICIPAL EMPLOYEES}

Before the Select Committee on Municipal Trading, I900, Mr. S. Chisholm, Lord Provost of Glasgow, testified as follows: "I never knew a (political) contest to turn on the condition of the municipal employees. . . . I do not think there is any real danger of combination among our city workmen; indeed I think if there was, the other workmen would be quick to see that, as they contribute either to the rates (taxes), as in the case of police or health, or any of those things which are payable by the rates, or as citizens to the tramways and other (municipal) undertakings, their interests are not the same as those of the corporation (municipal) employees. Any special advantage which the corporation employees might be seeking to obtain would be at the expense of the other workmen; and it would be a very difficult matter, I think, for a dangerous coalition, such as your Lordship refers to, to be formed." *

Before the same Select Committee, Mr. James Kelly, a Magistrate for Glasgow and a member of

* Report from the Joint Select Committee on Municipal Trading, I9o0; q. 277 I to 2783,2866 and 293 o. 
the Board of Management of the Trader's Defence Politics and Wages Association of Scotland, stated that as a rule in Glasgow only 50 to 60 per cent of the electors went to the polls, that the city employees exercised considerable influence in the wards in which they lived, and that some of the candidates for election made a point of bringing before the voters the special claims of the city employees. He said that, if desired, he would give the name of a Councillor who, in speaking to his constituents, had said that since he had been sent to the Town Council he had been the means of getting a certain number of men employment with the city. "Also that in the month of February, I900, in a discussion in the Town Council with regard to increase of wages to a section of the employees, one member who voted in favor of the increase said that he would make the constituents of another member who voted against it aware of the position which he had taken up." He then quoted from an election circular issued over the name of Mr. John Ferguson, the recognized leader of the local Independent Labor Party. This circular was issued on behalf of nine members of the Town Council in wards in which there were candidates standing against other candidates "who were not deemed to be labour candidates." It concluded with the words, "Vote for H. Murphy, the workers' candidate," and it gave the names of those who had voted for or against 
certain motions made in the Town Council. One of those motions had been, "That the wages of the able-bodied sweepers and labourers in the cleansing department be increased 2 shillings per week instead of I shilling, as recommended in those minutes." The circular also contained the statement, "My minimum of $2 \mathrm{I}$ shillings per week for the services of an able-bodied man is now, after long contention, accepted by the council." *

On November I9, I902, Mr. Vicary Gibbs, M.P., stated in a public address that within a week the Lord Provost of Glasgow, Sir John Ure Primrose, had stated that the city employees might become "a danger which might be destructive of the very best government of the city."

In May, I905, Sir John Ure Primrose expressed himself as follows to the special correspondent of The Daily Tribune, of Chicago: "Our exPolitical Power perience in municipal ownership of Employees has been generally successful, so far as we have confined ourselves to the proper channels of municipal activity. We have reached a point, however, where we begin to see a danger ahead, and this one which, from what I know of your peculiar political system, is likely to be even more threatening to you than to us. This arises out of the building up of a great army of mu-

* Report from the Joint Select Committee on Municipal Trading, I900; q. 3447 to 3459 . 
nicipal employees. For instance, in the tramway department, about which you have been making special inquiries, there are to-day over 4000 employees of the city. Then there are the men at work in the water department, the gas supply, and in the electrical works, in addition to the ordinary municipal departments. As the city grows, the army of employees grows, and there have been indications at times that they may wield a power in the dictation of the city government which is not altogether for the best interests of the municipality. For instance, not long since, one of our town councillors, in the course of his official duties and without any particular personal prejudice, was impelled to take certain action which was not relished by the members of the police force. There were not more than fifty of the constables, perhaps, who lived in his ward. Yet you can readily see that each one of these was a recruiting sergeant. The councillor was not wholly alive to the danger, and he was actually defeated through the efforts of the paid employees of the municipality. What is true of the police department may be true of the tramways department or any other large branch of the public work. Therefore, in the long run, even with us, where the municipality is divorced from politics, we have begun to see the danger which may arise from the existence of many thousands of employees, who are working for wages paid to them by the city, and yet who, to a certain extent, by the 
right of franchise, may yet be able to dictate the terms of their employment, and even the rate of wages. . . At a public dinner the other day $\mathbf{I}$ made a suggestion which embodies a remedy so radical that it brought down on my head a great deal of criticism, and yet I am not certain but that some such step must be taken to protect our municipalities in the operation of their public works. My suggestion was that it might be necessary to withhold the franchise on all municipal matters from city employees. . . . The multiplication of city employees . . . is certainly one of the weak spots in our municipal ownership programme." *

In an earlier chapter has been recorded the admission made by Sir Robert Cranston, Lord Provost of Edinburgh, to the special correspondent of The Daily Tribune of Chicago, that one reason why Edinburgh did not operate the tramways owned by the city was: "We consider ourselves free from political influence here in Scotland, but I must confess that now and then influences are brought to bear to secure employment in municipal plants which are not entirely worthy. ... The private companies are better adapted to run such systems, because they realize that the result of the employment of incompetent men will be to reduce their own profits. . . . The employment of incompetent men in responsible positions would be almost as bad for the public as if they were dishonest."

*The Daily Tribune, Chicago, May 8, 1905. 


\section{MUNICIPAL OWNERSHIP IN GREAT BRITAIN}

Before the Joint Select Committee on Municipal Trading, r900, Mr. E. O. Smith, Town Clerk of Birmingham since I88I, said: "Speaking purcly of my own personal opinion, I should like to see all corporate employees disfranchised." To the question whether he had found much pressure for higher wages among city employees, he replied: "I do not think it has been at all severe. This is a subject upon which one is obliged to speak with a great deal of delicacy. We had an all-round application from the workmen for an increase of wages a few months ago. We thought it undesirable that one committee should give an increase without consulting the others. We therefore got the chairman of the different committees together, presided over by the Lord Mayor, and we formed a special committee to consider it, and I think we did a wise thing. We put on that committee two workingmen's representatives, as they are called, and the result was that we convinced even the workingmen's representatives that there was no case made out for a general increase, but little inequalities were all corrected. That report was published, and the whole agitation has died away. ... I think when I came to Birmingham I heard some contrasts drawn by some speakers between a salary of $\$ 10,000$ a year paid to the town clerk, and the wages of some scavengers, but $I$ think that agitation died away. The scavenger got his increase, and the town clerk still remains at his $\$ 10,000$ 
a year. . . . I do not think we have had for many, many years any candidate what I may call giving away the case of the corporation as regards wages. I do not think it has ever been done. . . . You may think it an evil, but elections in Birmingham take place on (national) political lines; it is very curious it is so; why it should be so I do not know; I think it is because you can have only one kind of organization" * (i.e. you cannot have an organization for municipal politics and another for national politics).

Before the same Select Committee testified Sir Thomas Hughes, who had been an alderman since I878, excepting the two intervals during which he had been Mayor. He said: "I, myself, have always seen that danger (in a large number of city employees) and for that reason I have never cared to encourage municipal undertakings beyond what was absolutely necessary. . . . I strongly feel myself that the voluntary principle upon which most (city) officials of any position act, of never taking any part in elections, is a wise one, and I wish it was followed by all employees; in other words, I should not regret if it were made part of the conditions that a man taking employment in a municipality should not exercise his vote for municipal purposes while so employed. I have known an instance where combination was

* Report from Joint Select Committee on Municipal Trading, 1900; q. 1947 and 2056 to 2060 . 


\section{MUNICIPAL OWNERSHIP IN GREAT BRITAIN}

the occasion of a very good man being thrown out of his position as a councillor simply because they thought he did not favor that particular class [the city employees]... I I should gladly welcome [disfranchisement], but, so long as that is not the law, I shall always feel that the Corporation ought not, in their own interest, go beyond what is absolutely necessary in undertakings which might perhaps be better done by others." *

Before the Select Committee on Municipal Trading, 1900, Mr. J. W. Southern, who had been for twenty-two years an alderman in Manchester, stated that he shared the feeling of Sir Thomas Hughes. "There seems a disposition more and more for employees to coalesce, and although there may not be any absolute abuse in that direction to-day, yet there is I think a little cause for anxiety if these employees should band themselves together and vote for a candidate without regard to his fitness or to any other question but whether he will vote for an increase of their wages. If that came about it would be a very awkward thing, and it might lead to disfranchisement for municipal purposes of those who would otherwise elect their masters." In reply to the query whether he had known of a case of illegitimate pressure being put upon a candidate, the witness replied: "No, I cannot say I have. Still

* Report from Joint Select Committee on Municipal Trading, I900. q. 2304 . 
there is a distinct party now, the Independent Labour Party, which does not care for any other interests than those of labour, and they are becoming a powerful body. I hope the wiser men among them would rather avoid the abuse that this would be, because if it developed, it would require the intervention of Parliament." *

Before the Select Committee on Telephones, I895, Mr. H. E. Clare, Deputy Town Clerk of Liverpool, testified: "I deem it an axiom that any business Costliness of involving the employment of manual Municipal Operations labour will be done more cheaply by a company than by a corporation subject to November elections. . . . My experience of local government leads me to this conclusion: that if a thing can be done by a corporation for a fixed sum of money, it can be done by a contractor for a less sum, because there is always a certain amount of expense in connection with a public body which a contractor manages to save, and to make a profit where a corporation would only pay its way. . . . I do not approve at all of the corporations' working tramways; I believe in their owning them, but not working them." $\dagger$

In February, I904, two weeks before the date set for the London County Council elections, the Council

* Report from Joint Select Committee on Municipal Trading, rgoo; q. 2475 to 2477 .

$\dagger$ Evidence taken from the Select Committee on the question of adequacy of the Telephone Service in Local Areas, 1895; 4351, 1268, and 1476. 
issued as a public document a return which recorded the increases in the wages of the London County Council employees in the period from 1899 to I904. The Council at that time itself carried out many public works instead of letting contracts to contractors and builders. Therefore the list contained a large number of instances of increase of wages to men in the building and engineering trades. The list showed increases in the aforesaid trades rising to 16,33 , and 38 per cent. Upon these increases Engineering, * a journal of the highest standing, commented to the effect that the Board of Trade returns showed that since 1899 the general rate of wages in the engineering and building trades had not increased one per cent. It added that the London County Council employed upward of 12,000 workers, that only 260,000 persons took the trouble to vote $\dagger$ at London County Council elections, and that many candidates were elected by a majority of less than five per cent.

In reply to this article The Municipal Journal $\ddagger$

* February 26, 1904.

† The Municipal Journal, April 29, I904.

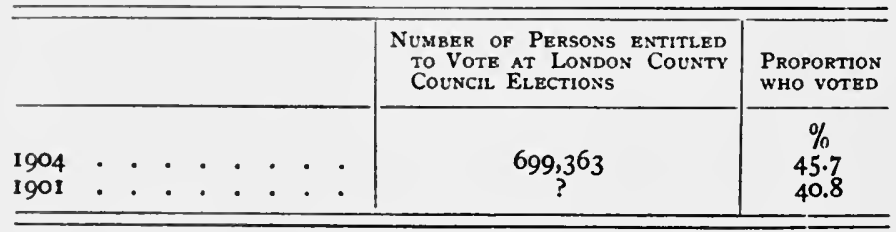

$\ddagger$ March 4, 1904. 
wrote: "Engineering is concerned lest the I2,000 employees of the London County Council will influence to-morrow's election, and the journal gives a pathetic list of those trades in regard to which the authority has increased wages and improved the conditions of labour. What would Engineering? Would it sweat municipal workmen so that they would vote against a particular party? ... As there are no candidates opposing the Council's labour policy, what does it matter whom these I2,000 workmen vote for?... Why does this well-meaning journal persist in raging against the inevitable?"

In December, 1902, the London County Council was preparing to construct vaults at Knightsbridge in connection with a widening of the streets. The Council's Department of Works estimated that the brickwork would cost the Council \$I40 per rod. Mr. M. R. Clutton, the agent for very large land and house owners in London, by way of comment upon the Works Department's estimate, said that the British Office of Works' "jobbing contract for the same description of work, whether in a basement or on the top of a high building, is $\$ 95.50$ per rod. This, in my opinion, would make $\$ 90$ per rod a very fair price for vaults." Lord Avebury added that the Chairman of the London County Council recently had stated that a County Council bricklayer would lay, on an average, only 300 bricks a day.*

* Lord Avebury: Essays and Addresses, rgo3. 
The foregoing episodes recall to mind the fact that the late Lord Farrer was returned to the London County Council after he had retired from the Board of Trade, and that, "in a moment of economic remorse, he once challenged the Council to let a part of a proposed public work be carried out by a contractor, while the Council, for purposes of comparison of results, carry out the remainder of the work." *

When the late Mr. Bagehot was writing his book upon the British Constitution, and had reached the chapter which was to treat of the Queen, he remarked that he was embarrassed by lack of material, for thus far there had been appointed no Royal Commission or Parliamentary Select Committee "to sit on the Queen." Any one writing to-day upon the municipalities and their employees is similarly embarrassed by lack of material. It is true that in 1900 and again in 1903 a Select Committee was appointed to report on Municipal Trading, but those committees did not inquire at all exhaustively into the question of the municipal employees. In fact, they did not touch the fringe of the question.

On the other hand, there is available a vast amount of official information on the employees of the British Post Office and the British State Telegraphs. The study of that material has re-

* D. H. Davies: The Cost of Municipal Trading, p. 60. 
vealed to the author a condition of affairs so absolutely at variance with the accounts of the workHouse of Com- ing of the British civil service given mons under Civil even by the better class of writers, Service Control that he is entirely unable to accept the statements to be found in the unofficial and current literature of the day to the effect that the administration of the British municipalities is businesslike. To the author the question is an open one, which must remain so until authoritative that is, official-evidence is submitted. Comparison, over a wide range of countries, of the evidence revealed in official documents with the reports spread broadcast by "birds of passage," who study problems "on the spot" without any perspective or background, has led the author to lay little value upon such reports. Suffice it to say, therefore, that at present there is no documentary evidence on the question of the municipal employees of the United Kingdom; but that such fragments of documentary evidence as have become available seem to indicate a tendency of the municipal civil service to develop along the lines of the national civil service of the United Kingdom.

In conclusion, it may be stated that the national civil service of Great Britain has the British House of Commons completely under its thumb, and compels that body to prevent the British Government from administering its great trading depart- 
ments, the Post Office and the Telegraphs, in a businesslike fashion. The work of the trading departments is done efficiently, if one look only to the service rendered to the public; it is done wofully inefficiently, if one look at all at the cost of getting it done. The British Government has lost control over wages and salaries; it cannot dismiss men made superfluous by the invention of labor-saving devices or methods; it does not pretend to dismiss men for incompetency; it has very little power to dismiss men who are not amenable to discipline; it cannot promote men according to merit, but must promote all but exclusively by seniority. Members of the House of Commons intercede, not only behind the scenes, but openly and from the floor of the House of Commons, at one end of the scale on behalf of men dismissed on account of theft, and at the other end in behalf of girls in the central telephone exchanges who have been passed over when it has been necessary to promote some one. Mr. Austen Chamberlain, when he held the office of Postmaster General, stated in the Commons that one-third of the time of himself and his leading men in the Post Office and Telegraphs was given to the consideration of petty questions of discipline, which in a private business would never reach the men holding positions requiring great executive capacity. Finally, a leading executive officer has stated before a Par- 
liamentary Select Committee that the men whose duty it is to determine the scales of payment and to maintain discipline make it their practice, on reaching their offices in the morning, to turn first of all to the report of the proceedings in the House of Commons on the day before, to ascertain the "temper of the House," and that they govern themselves accordingly in the administration of the great business enterprises over which they are supposed to preside. "The House of Commons are our masters" were the words with which one of the highest officers, if not the highest one, in the State's service, pleaded the interference of members of the House of Commons as an excuse for not getting rid of unworthy public servants. He added, "It is not a good reason, but as a matter of fact it is powerful." 


\section{CHAPTER XIX}

\section{CONCLUSION}

THE doctrine that the public service industries which use the public streets differ essentially from ordinary trading and manufacturing ventures, and Governments that they should be subjected to Rarely can Re- special limitations and special taxaverse their Steps tion designed to secure to the public at large a share in their profits, has permanently paralyzed every public service industry to which it has been applied. A number of the leading statesmen of Great Britain have come fully to realize that fact, but they have learned at the same time that it is extremely difficult for governments to reverse their steps. Politics is the great art of compromise. Politicians as a class are as patriotic and as disinterested as any other class of the community; but they are sadly handicapped by the conditions under which they must carry on their great and public-spirited labors. They set about their work by asking themselves what is the ideal thing to do. After that comparatively simple question has been answered comes the real problem: How far will the conflict of sectional 
interests and class interests, class hatred, popular prejudices and popular misconceptions permit the attainment of that ideal? And how far does it compel the modification, or even the practical sacrifice, of the ideal? Therein lies the explanation of the fact that no serious effort has been made to abandon, or even to modify, the policy entered upon in I870-namely, to seek to secure to the general public a share in the profits to be made in the industries that use the public streets. It was a very easy matter to announce that doctrine and to cause it to spread over the whole land; but when it was found that the doctrine worked disastrously in a workaday world, it turned out to be impossible to arrest and to overthrow it.

After the British cities had paralyzed individual initiative and private adventure, they declined themselves to step in and fill the void created. Progress Depend- Therefore the task of establishing ent upon successively the horse street railway Freedom in the industry, the electric lighting indusUnited States try, the telephone industry, and the electric street railway industry was left to the United States, the only country which in the pregnant period from I870 to I 900 granted to public service companies charters that were sufficiently liberal to induce such companies to assume the great risks and losses which are an unavoidable incident to the establishment and the subsequent develop- 


\section{MUNICIPAL OWNERSHIP IN GREAT BRITAIN}

ment of new industries. Had the United States pursued the policy of the rest of the world, the electric light, the telephone, and the electric street railway to-day would be, not accomplished facts, but tentative experiments. The English and the German municipalities contributed nothing to the development of those industries, but purchased them "ready-made" of the United States.

The British cities thus far have shown themselves incapable of utilizing fully the industries given them ready-made by the American captain of industry. Nowhere in Great Britain has the electric street railway been used for the purpose of decentralizing or "suburbanizing" the population of the large cities. In this matter the British cities have shown an indifference to and a disregard of the public health, physical as well as moral, that for brutality have no parallel in the records of private industry. Scarcely less brutal is the disregard by the British cities of the welfare of the more than one hundred thousand people who might find employment in the electrical industries, would the cities but remove from those industries their paralyzing hand. In this persistent and brutal disregard of the public welfare we should find a lesson calculated to make us refuse to accept without question the statement - which we are constantly asked to accept as an axiom - that the State necessarily and always is a beneficent body. 
The experience of Great Britain also reveals the untenableness of the argument that, granting that public bodies cannot build up new industries Governmental or contribute to the further developObstruction to ment of established ones, they yet Progress may be intrusted with the conduct of industries that have reached the stationary stage. In the first place, there is no industry of which one can say with finality that it has reached the stationary stage. In the second place, every industry, no matter what its stage of development may be, is liable to be displaced wholly or in part by some new industry. That is one of the ordinary risks of trade. But the British cities, as well as the British nation, absolutely refuse to accept that risk. The British cities refused to expose their gas plants to competition from the electric light; subsequently they refused to expose their local electric lighting plant to competition, even in the supply of current for power, from the more modern electricity-in-bulk generating stations. The British Government, on the other hand, has persistently refused to allow the telephone to compete freely with the telegraph. The argument that a business in which had been invested "the people's money" must not be impaired by competition from a "dividend-seeking" company has thus far always swept everything before it, completely blinding the people to their own interests. 


\section{MUNICIPAL OWNERSHIP IN GREAT BRITAIN}

The upshot of thirty-five years of action upon the doctrine that the public service industries that make use of the public streets differ from ordinary trading and manufacturing ventures, and must be made to share their profits with the public at large, is that the people of the United Kingdom have at their disposal about one-quarter the street railway facilities, one-third the electric lighting facilities, and less than one-quarter the telephone facilities, that they would have to have before they could be said to be as well supplied with these facilities as are the people of the United States. Furthermore, fully 120,000 persons who might be making a living in the United Kingdom in the electrical industries have been obliged either to emigrate from the United Kingdom or to join the ranks of the unemployed. Finally, there is reason to fear that the Tramways Act, 1870, and the Electric Lighting Acts, 1882 and 1888 , have caused England, to repeat the words of one of England's most brilliant mechanical engineers, the late Sir Frederic J. Bramwell,* "to lose forever her proper position in the manufacture and supply of electrical machinery."

The reader will remember that the late Lord Farrer, as Permanent Secretary of the Board of Trade from $\mathrm{I} 867$ to $\mathrm{I} 886$, invariably threw the great weight of his official position and his per-

* Journal of the Society of Arts, January 30, 1903. 
sonality on the side of municipal activity and against individual initiative and private enterprise; and that "his judgment and experience, in his own time, largely guided the government" * in all matters coming within the domain of the Board of Trade. Lord Farrer was prompted to take that course in part because he feared that "there was a serious political evil to be apprehended from the growing influence of the great joint-stock company interest in Parliament and in local governing boards. This evil is, if report speaks true, a very serious one in America. In this country it is as yet not much felt, except in the combined resistance which the companies make to any alteration of the law which affects themselves. But the success and ability with which they can do this is, considering the ever widening sphere of their operations, a great evil in itself, and if they should ever turn their powerful organization to a political purpose, it would become a national calamity." $\dagger$

This quotation shows that Lord Farrer had apprehended the truth which the late Lord Acton, in his day perhaps the most learned man of England, had said was the most fundamental truth taught by the study of history - that great power, wherever lodged, is dangerous. But the application which Lord Farrer made of the great truth

* Sir Robert Giffen, in the supplementary chapter which he wrote for The State in its Relation to Trade, by T. H. Farrer.

$\dagger$ T. H. Farrer: The State in its Relation to Trade, p. I23. 
which he had apprehended - namely, the transfer of political power from the joint-stock companies to the local governing bodies - shows that Lord Farrer belonged to that numerous class of persons who forever are treating symptoms and not the disease. Great power, wherever lodged, is dangerous; but the way to meet that danger is not forever to be changing the person or the place where power is lodged. The way to meet it is to train the citizens of the country to such a pitch of civic virtue and political intelligence that power cannot be abused, no matter where lodged. To pursue any other course is merely to jump from the frying-pan into the fire. Lord Farrer himself lived long enough to have overwhelming proof of the fact put before him, as is shown by the subjoined quotation from Lord Alverstone, the present Lord Chief Justice of England, who spoke from experience gained as a Member of the House of Commons in the years 1885 to 1900 . Said the Lord Chief Justice: "He wished to allude to one part of the subject which had only been touched upon by the author, but which he [Lord Alverstone] as a member of the House of Commons for a great many years had frequently had pointedly brought before his notice. The author had referred to the Municipal Corporations Association. Only those who had been in the House of Commons knew the really almost unfair weight and power 
which municipal bodies had in the House, because, not only did the local member not dare to resist the wishes of his local friends, but all the municipal corporations acted together, and when there had been an attempt to get statutory powers for private enterprise which was thought to conflict with the possibility of municipal trading in a particular place, not only was the influence of the municipality in that particular place set to work, but the influence, through the Municipal Corporations Association, of many other municipal bodies which had nothing whatever to do with the particular scheme. Without fear of contradiction he could say that the question under those circumstances was not fairly determined upon its merits, and was not fairly discussed. Being no longer in politics he had no right to express any opinion upon the merits of the case, beyond saying that it was a question of such vast importance that it ought to be thoroughly understood and tested upon its merits and not dealt with by any considerations of popularity, public sentiment, or anything of that kind." *

Industrial progress comes not from the people at large, whether acting as individuals or in the corporate capacity of state or city. It comes solely from a comparatively small body of men of unusual imagination, daring, power of persuasion, * Journal of the Society of Arts, January, 1903. 
and executive ability. Those men see, or believe they see, possibilities of development and new ways Industrial Devel- of doing things, where the average opinent due to man sees naught but the possibility Individual Initia- of failure. They have the courage tive

of their convictions, as well as the power to infuse that courage into others - the possessors of the capital without which no new idea and no invention can be tested and developed. Finally, the men in question have executive ability, which is the power to plan, and the ability to select the men who can be trusted with the execution of their plans.

The United States differs from Europe not so much in the possession of men of this unusual type, as in the fuller use that it makes of such men of this type as it possesses. For this difference between the United States and Europe there are two reasons. One of them is the extraordinary stimulus afforded by our democratic institutions and a virgin country, rich in resources of all kinds and calling men of courage and imagination to the utmost pitch of activity. The other reason, and the more important one, is that we have more of "that liberty which is the nurse of all great wits" as well as of all spirit of adventure. "What is it that has made Americans what they are but their passion for individual freedom, their habit of acting on their own judgment and their own 
initiative, and their dislike, I may say their scorn, for the leading-strings of official authority? Without that freedom of individual action the United States can never continue to be in the future what it has been in the past." Every extension of the functions of the State and the City will impair that freedom of individual action, and therefore it is to be resisted to the utmost. Only as a matter of last resort, of the last means of escape from ills that can no longer be borne, should we have recourse to extending the functions of the state or the city.

In the meantime, comparison of our experience under the policy of the minimum of governmental intervention - the priceless heritage bequeathed to us by our forefathers - with the experience of Great Britain under the policy of the maximum of intervention, shows us that we have no ills that call for the heroic remedy of treating the public service industries as industries differing in any way from ordinary trading and manufacturing ventures. We have more street railway facilities, electric lighting facilities, and telephonic facilities than have our British cousins; and we make more use of our ample facilities than our British cousins make of their restricted facilities. This shows that the prices charged to us by our companies under the stimulus of an enlightened self-interest are better adapted to our purses, than are the prices charged to our British cousins by their city fathers. 


\section{.}




\section{INDEX}

Aberdeen and Dundee, conditions demanded for assent of, to a Provisional Order, 24

Administrative County of London Electric Power Bill talked to death in the Commons, 29I-4; provisions of, 292-3; had a strong support, 293; opposition, 294

Air, compressed, and hydraulic power, under consideration at Leeds, $215^{-6}$

Alverstone, Lord, on power of the Municipal Corporations Association, 328-9

American practice toward public service companies, I

Arc light, discovered by Sir Humphry Davy, 4

Armstrong, Sir W., established earliest private electric-light installation, 4-5

Asphalt pavements to supersede street railways, 147

Balfour, Gerald, replies to committee on improving electrical legislation, $82-5$

Bazalgette, J. W., thought asphalt would remove necessity for tramways, 147

Bellamy, C. R., on tramway fares in Liverpool, 112-3

Bill for street railway over Westminster Bridge, arguments against, I 5 I-4

Birkenhead, street railway built in, by George Francis Train, 8

Birmingham, arguments of Joseph Chamberlain for purchase of gas plant of, I6-1 7; street railways in, ${ }_{3} \mathrm{I}-5$; building of, discouraged, 132-3; lack of transit facilities and overcrowding in, $134-5$

Birmingham Committee, report of, on city's incompetence to take hold of a new industry, 221-8; electric light company in Birming- ham, 229-3I; plant transferred to the city, $23 \mathrm{I}-2$

Blackmail in demands of local authorities from promoters, 49

Board of Trade to give certificates for laying down tramways, I4; authorized to grant, with consent of local authorities, Provisional Orders, 22; should be constituted friends of the public, 32 ; obliged to warn local authorities, 35-6; unable to provide scheme of tramways for London, 143; scandalous manner in which Act of 1888 on electric lighting was administered by the, 242; influence of local authorities with, 244-6, 252-3; difficulty of obtaining electric lighting charters from, 247-5I; refusal of, to overrule provisional veto, 253 ; discrimination of, against companies, 253-9; notice of, to applicants for charters, 266; sides with municipalities, 288-9

Boston, street railway fares in, $108-9$

Boston Elevated Railway Co., earnings of, taxed, 101-2

Boyle, Sir Courtenay, on purchase of remunerative gas plants, 182; on overruling provisional veto, $245^{-6}$

Bradford, ruling of Light Railways Commissioners on tramways near, 74-6

Bramwell, Sir F. J., on compelling power of municipalities, $175^{-6}$; on electric lighting, 209-10

Bristol, street railways in, owned by a company, $14^{\circ}$

Bristol Gas Co. denied enlarged powers, I77

Broadhurst, Mr., against the Lancashire Power Bill, 28I-2

Bureaucrat versus men of affairs, $51-7$

Bureaucratic mind, a study of the, 202-3

Burns, John, on unreasonable vetoes by Councils, 154-5 
Cable street railway, first, in United States opened, 57; in Edinburgh, 125

Cable system not used on British tramways, 57; authorized by a Provisional Order, 57; reason for failure, $5^{8}$

Cable traction, excessive cost of equipment for, in Edinburgh, 1 27-30

Calcrait, Sir H. G., argued for compulsory sale at structural value, $218-9,229$; on confidence of Board of Trade in decisions of local authorities, 244-5

Capital, American, supporting street railway schemes in England, 2r-2

Capital, and electric lighting, 185 , 187 ; tenacity of British capitalists, 197; attitude of, towards new industries, 207-8, 21 4-5; deterred by compulsory sale clause, 210-1; thirty years' franchise not enough for, 220

Capitalists of Great Britain, record of, for venturesome investments, 3; afraid of street railway ventures, 21,133 ; ready to experiment, 61-2; eager to put electric light in competition with gas, 265

Carrington, Lord, against tramways over Westminster Bridge, I 53

Chamberlain, Joseph, in favor of municipal ownership of industries using streets, 16; a champion of municipal trading, $62,130,173$; on municipalization of gas works, I $3 \mathrm{I}$; introduced Electric Lighting Bill, 186 ; speech of, on same, $188-$ $90,194-5$; retired from office, 200 Chaplin, Mr., on Standing Order No. 22, 47-9; withdrew his amendment, 51

Chisholm, Samuel, on electric supply in Glasgow, 239-40; on municipal employees, 307

Cities confess their incompetence to take hold of a new industry, 221-40; report of Birminghani Committee, $22 \mathrm{I}-8$; difficulties in the way of electric lighting, 223-4, 227-8; no analogy with undertaking the supply of gas, 225-6; gas the most effective illuminant, 228 ; value of experiment and experience, $228-9$; failure in Liverpool and four other cities to install electric lighting plants, 232-3; a company in Liverpool, bought by the city, 233-4

Civil Service control of the House of Commons, 319-21

Cohen, Lionel, on prohibitive effect of Act of $1882,210-11$

Commons, House of, under civil service control, 319-2I

Community, welfare of, promoted by the individual or company, 2 ; more benefit to, by reducing fares than by reducing taxes, 14; no desire for promotion of, I 7 I

Consumer, municipalities versus the, $240-65$

Continent, street railways in cities on the, ro

Cranston, Sir Robert, on municipal management, 128-30; on political power of municipal employees, 3 II

Davenport, Mr. Bromley, on the General Power Distribution Bill, 273-4

Davy, Sir Humphry, arc light discovered by, 4

Donelly and District Tramway Co., compulsory purchase of, ordered under Light Railways Act, 80

Dublin, tramway service in, 96-7

Edinburgh, question of housing the poor in, 55; tramways to decentralize the population, 56; ruling of Light Raifway Commissioners on a tramway in, 74; street railways in, II 7-30; tramways under private management favor working classes, II 8 ; development retarded by opposition of city, $119-23$; experiments with steam, 123 ; plant sold to city, 124; city converts horse car system to cable, 1 25-7; unbusinesslike management by municipality, 127; "soaked" the operating company, I 28 ; obtained electric light charter and delayed supplying current, 238; owns gas plant, $23^{8}$

Electric current, different prices charged for, by city of Bristol, I 77

Electric lamp, earliest incandescent, made by Swan, 4

Electric light companies, so-called " marauding," 196-7; town clerks and councillors on the, $212-8$

Electric lighting, incompetence of cities to take hold of, confessed by 
Birmingham Committee, 221-8; alleged difficulties, 223-4, 227-8; value of experiment and experience, 228-9; failure of Liverpool and four other cities to install plants for, 232-3; a company in Liverpool, bought by the city, 233-4; Manchester gets charter to keep out companies, 234 ; profits applied to reduce taxes, 235 ; Sheffield admits a company and buys it out, $235-6$; Leeds admits a company on its agreement to sell, and pays in city stock, 236-7; Nottingham secured a charter to keep companies out, supplied current and owns gas plant, 237; Edinburgh obtained a charter, delayed supplying current owning gas plant, 238; Glasgow bought out a "marauding" company, and claimed to profit by dilatoriness in extending, $23^{8-40}$; municipal policy prevents development of, 247 ; the United Kingdom outstripped by United States in, $259^{-62}, 29^{8-300 ;}$ task of establishing the industry left to the United States, 323

Electric Lighting Act, I 882, 184-99; Board of Trade misjudges the situation, I85-6; speeches of $\mathrm{Mr}$. Chamberlain on, 188-90, 194-5; opposition to long franchises for, r90-2; opposition mainly from gas companies, I93; Bill amended, 193-4; charters taken out under, revoked and development checked, 195; "marauding" companies a result, $196-7$; attempts to liberalize the, $200-2$; three Bills referred to a Select Committee, 202; evidence given before Committee, 203-20; Act of 1882 killed the industry, $204,209,2 \mathrm{II}$; testimony of town clerks and councillors, 212-8; effort to amend, abandoned, 220 ; Amendment Bill, I888, passed, 24I; aimed to remove prohibitive restrictions, 24I-2; compulsory purchase clause, 242; aimed to remove prohibitive restrictions, 242 ; provisions of, requiring provisional consent, should be amended, 246; one law for local authorities, another for companies, 257; not amended, $29 \mathrm{I}$

Electric lighting industry, paralysis of the, 59-60; development of the, in Great Britain and the United States, 204-5; losses in experimenting, 208; no necessity for putting, on an equality with gas, 2 5-6; progress in, not worth its cost, 218-20; Report of Birmingham Committee on, 221-8; paralyzed in Great Britain for six years, 240.

Electric lighting plants, municipalities having, anxious for electric tramways, $41-3$

Electric railway, first, from Berlin to Lichterfelde, $5^{8}$

Electric railways, heavy losses in developing, 64-7; in the United Kingdom and the United States, 301 ; establishment of, left to the United States, $\mathbf{3}^{2} 3$

Electric service in United States and Great Britain, 26r-2

Electric stations, central, in United States, 63 ; in the United States and Germany, 197-9; in United States and in United Kingdom, 259-62, 30I-3

Electric supply companies, twentyfour, authorized, 289-9o

Electric tramways, number of, in United Kingdom, 58-9; reasons for failure to develop, $59-60$; in United States, 59; twenty-oneyear period too short, 6o; opposition of municipal gas plants, $6 \mathrm{I}-2$

Electrical engineering, Great Britain had lead in earlier stages of, 4; behind since 1870,6

Electrical industries, Committee to report on legislative policy toward, 80; conference of, with Mr. Balfour, 81-2; Mr. Balfour's explanation of the Government's position, 82-5; British outstripped by the United States, 298-300; other, $303-4$

Electrical theory, in development of, Great Britain has held her own, 5

Electricity as an agent for the transmission of power, 305

Electricity Supply Bill introduced three times and withdrawn, 290-5; argument against, on second reading, 295-6

Electricity, wholesale supply of, prevented, $267-72$

Employees, municipal, 307-2I ; politics and wages of, 308-II; should be disfranchised, $3^{12-4}$; increase 
of wages of, in London, 316-7; lack of material on, 318

Engineering trades, Great Britain second to no other country in, 3

Falshaw, Sir James, against steam tramways in Edinburgh, $123-4$

Faraday, made fundamental discoveries in electro-magnetism, 4

Fares, provisions for revision of, $33-4$; graded, in Glasgow, $103-16$; decentralization not accomplished by, 107; give narrow margin of profit, ro7-9; benefit wage earners little, III; extension of I-cent stage demanded, I 10-1 2; uniform, recommended by commission on transportation in London, 168

Farrer, Mr. T. H., testimony of, before Committee of Commons, 52-3; compared with published returns, 54-5; on electric lighting, $185^{-6}$; on power of provisional veto, 243-4; and the London Council, 318; favored municipalities; feared monopolies, 326-8

Fleming, J. A., on development of electrical industries, 5-6

Forbes, George, on electrical development, 203-4

Forbes, J. S., on the Board of Trade, 206-8

Franchises should be sold or leased, I .

Galloway, Mr., against the Lancashire Power Bill, 280-I

Garcke, E., on attitude of local authorities toward tramway companies, 40-4; on English, German, and American manufacturers of electrical apparatus and supplies, 299-300

Gas companies, sliding scale of price and dividend for, $201-2$

$\mathrm{G}$ as plants, municipal purchases of, 172-83; sales of plants by companies usually compulsory, i 75-82; profit goes to municipality, not to consumers, 182; in the United Kingdom, 262-3

Glasgow, Light Railways Commissioners disapprove a tramway act, 74 ; street railways in, 93-102; assumes operation of tramways, 94; partial electrical equipment, 95; opposes perpetual franchises except for itself, 95; promises of, contrasted with achievement, 97; fails to suburbanize population, 99-101, ro7; financial results in, IOI; proves that graded fares mean congested population, $103-16$; committee on desirability of acquiring outlying land bordering tramways, I I 4-5; bought electric light plant of a "marauding" company, 238; gains claimed from dilatoriness in extending, $239^{-4}$; politics and wages of municipal employees in, 308-I 1

Grove, Sir William, made earliest electric accumulator, 4

Hall, Sir Benjamin, moved rejection of Bill for street railways in London, 7

Harper, E. J., on tramway congestion in London, $165^{-6}$

Harrison, Charles, on subways in London, I69-7I

Hereford, no more city rate in, 173-4.

Hopkins, Mr., on cost of paving to tramway companies, 24 ; testimony of, regarding demands of road and local authorities, 26-7; on use of steam, 54

Hopkinson, Dr. John, worked out design of dynamo machinery, 4

Horse railways, long-lived charters of, in United States, 63 ; changed to electric, $64-7$; close of the era of, in United States, 96; task of establishing, left to the United States, 323

Hughes, Sir Thomas, on electric lighting in Liverpool, $233-4$; on danger in large number of city employees, 313-4

Hunter, Robert, on Electric Lighting Act, $1882,197 \mathrm{n}$.

Individual freedom of action, passion of Americans for, 330-1

Industrial development due to individual initiative, $33^{\circ}$

Intervention, Minimum of governmental, a key to our industrial successes, $33 \mathrm{I}$

Inventiveness, British, in check since $1870,4^{-5}$

Lancashire Power Co. Bill, opposition to, 278-83; debate on, 280-3; passed, 284; extent of area covered by, 284-5

Lands, outlying, municipal owner- 
ship of, II4-6; settlement of, near London, 162-4

Leeds, street railways in, $138-9$; rejected electric for compressed air and hydraulic power, 215-6; admitted one company and bought it out with city stock, $236-7$

Leigh, E. C., on purchases of gas plants by local authorities, I 79-82

Light Railways Act, Veto power of local authorities against principles of, 47 ; chapter on, 68-85; Provisional Orders issued under, 70 ; enables promoters to evade restrictions of Tramways Act, 78; not amended, $29 \mathrm{I}$

Light Railways Commissioners, rules governing proceedings of, $7 \mathrm{I}-3$; rulings of, in Edinburgh, Glasgow, Bradford, and other places, $71-8$.

Liverpool, statistics of tramways in, I 13; street railways in, r 39 ; failure of local authorities to install electric lighting plant, 232; private company plant bought, $233-4$

Local authorities, almost invariably sell their assent for a tramway, $22,27,46$; difficult to make terms with, 26; undue pressure of, to be prevented, 3I; Mr. Arthur Peel on, 3I; veto power of, not limited, 33, 44; enforce bargains with promoters, $37-8$

London, Greater, street railways in, I 4r-7I ; local interests check development of tramways in, $\mathrm{r}_{\mathbf{4 2}}-5$; Parliamentary committee on metropolitan tramways, $\mathrm{r}_{45}-8$; recent opposition to tramways by private interests, I $5 \mathrm{I}-4$; misuse of veto power by boroughs and County Council, I54-7; inadequacy of tramway service in, $158-60$; overcrowding perpetuated, 16r-2; outlying lands near, inaccessible, I62-4; more tramways needed, 164-7; public necessity versus municipal gain, $169-71$

London, Metropolitan, charters for street railways in, refused, $7-9$; three schemes for street railways in suburbs of, sanctioned, 9-10

Losses in development of new industries, 66, 323-4

Lowther, J. W., on blackmail by local authorities, 49-50; on twentyone-year franchises, 60; on the veto power, I56; on electric supply in Manchester, 235

Lubbock, Sir John, on compulsory sale, at structural value, 187 ; on opposition of gas-making corporations to charters for electric lighting, 248-9

Macdona, Mr., favored Lancashire Power Bill, 279-80

Magden, Mr. W. L., on refusal of local authorities to consent to Provisional Orders for electric lighting companies, $249^{-5}$ I ; orders obtained for blocking purposes, 259

Manchester, street railways in, ${ }_{3} 6-8$; established electric light plant to keep out six companies, 234; profits applied to reduction of rates (taxes), 235

Manufactories, decentralization of, desirable, 305

Manufacturer, municipalities versus the, 266-97

Manufacturers need cheap electrical power from central stations, 276-7

Monopoly, claims to, prevented, $266-7,270$

Morley, Earl of, on Standing Order No. $22,44-7$

Morris, John, speaks before committee as witness of tramway interests, 14

Morrison, Sir G., on electric lighting, 2 I $4-6$

Morse, Mr. Sydney, on local authorities, oppression of tramway companies, $39-40$; on difficulty of obtaining charters for electric lighting, $247^{-8}$

Municipal authorities, granted power to lay down tramways with consent of Board of Trade, $13-14$; duties and responsibilities of, should be increased, I7; abuse of veto power by, 22, I I 9

Municipal Corporations, Association of, political pressure cxercised by the, 70; power of the, 78; Government afraid to antagonize, 79, 220 ; permitted amendment to Electric Lighting Act of 1882, 241-2; defeated the General Power Distribution Bill, $27 I_{-2}$; influence of, in the Commons, 274, 328-9; opposed to Lancashire Power Co. Bill, 279 
Municipal opposition to progress, 272-6

Municipal ownership, of outlying lands, I14-16; experience gained under, in Great Britain, not highly valued, 203; Report of Birmingham Committee, 1882, $22 t-8$

Municipal public service industries should share their profits with the public, 1, 16-18, 52; effect of application of this doctrine, $9^{I-2}$

Municipal trading, 51-3; Joseph Chamberlain a champion of, 62 , 130; effects of advocating, 86; craze for, 210; on difficulty of obtaining charters from the Board of Trade, 246-53

Municipal Trading, Testimony before Select Committee on, $3^{8-44}$

Municipal undertakings, financial weakness of, 296-7; costliness of, $3^{15}-7$

Municipalities, complete failure of, to advance new industries, 21 ; seek to acquire plants of flourishing companies, 181,186

Municipalities versus consumer, 241

Municipalities, versus the manufacturer, 266-97; Parliament helpless before the, 290-5

Municipalitics, versus the wageearners, 298-306; political danger to, from municipal employees, 308-14; brutal disregard of public welfare, $324-5$

Municipality should own and conduct public service industries, I, I6-18

Munro, Mr., on conditions in Glasgow, 98

Murphy, W. M., proposes system of electric traction for Dublin, 96-7

Newton, William, on jurisdiction of local and road authorities in granting tramway lines, 23, 144; on tramways in crowded streets, I45

Nottingham worried gas company into selling out, 176; obtained electric light chartcr to keep companies out, 237; owns gas plant, 237

O'Connor, T. P., argument of, against tramcars, 152

Omnibus, motor, used to displace tramways, I 49-50

Parliament helpless before the municipalities, 290-5
Parliament influenced more by the municipal corporations than by the builders of tramways, 15-16

Parrish, D., experience of, with road and local authorities, 26

Paterson, D. W., testifies that Edinburgh Tramway Co. had to conciliate corporation, I I9, I 2 I

Paving, amount of, to be done by tramways fixed by Act of 1870, 23 ; amount demanded by local authorities in Metropolitan London, 24

Peel, Arthur, on steam power, 20-30; opinion of, local authorities should make contracts with promoters of steam tramways, $3 \mathrm{I}-3$

Pickersgill, Mr., opposes monopolist companies, 274-5

Politicians handicapped in doing their work, 322-3

Population, tramways to decentralize, 56; graded fares mean a congested, $\mathrm{IO}_{3}$; decentralization of, in American cities, 108 ; congestion of, in Birmingham, r $33-4$; overcrowding of, in London, perpetuated, I6I-2; decentralization of, by subways, I 66-8

Power Distribution Bill, the General, 268-7 I ; supported by Chambers of Commerce, 270-1; debate on the, 271-6; a direct attack on municipal corporations, $275^{-6}$; cost of, to the promoters, 277; revived in 1901 , 285-6

Preece, W. H., on electrical development, 204-5

Prejudice, the appeal to, $280-3$

Private initiative, conditions which destroyed, 27-8

Profits, shares of, demanded by local authorities, $34-5$

Progress, dependent upon freedom, $3^{2} 3-4$; governmental obstruction to, 325-9; industrial, due to individual initiative, $33^{\circ}-1$

Promoters, private bargains between local authorities and, 36-7; local authorities have means of enforcing, 37-8; "we should bleed them," 40; regard conditions often as blackmail, 49; willing to face risks on long-lived franchises, 67 ; result of a bargain, 72-3; demands of Edinburgh upon, II $9^{-21}$; on difficulty of obtaining charters, 247-53 
Provisional Orders, granted by Board of Trade with consent of local authorities, 22-3; conditions demanded for consent for, 24-7; provisions in, for use of mechanical power, 33 ; conditions named by different local authorities, 34-7; provisions disallowed made subject of private bargains, 36-7; use to be made of, 244 ; refused to electric companies where corporations owned gas enterprises, $248-53$; discrimination in favor of local applicants, 253; may be revoked on failure to supply current, 255 ; issued to local authorities with no supply available, 256 ; taken out by local authorities to reserve field for municipal plants, $25^{8}$

Provisional Orders of Light Railway Commissioners, Regulations of, 70-3

Public authorities more solicitous for welfare of the people than trading companies, 2

Public service industries, doctrine concerning, in Great Britain, 2; special value of Great Britain's experiments with, 2-6; paralyzing effects of the doctrine, 322-3; its cost to the nation, 326

Purchase clause, under Acts of 1869 , Mr. Shaw-Lefevre on, 13; tramways acquired by municipalities under, of Tramways Act of 1870 , 20; of 1882,62

Purchase clause demanded in charters for subways, 169-70

Purchase clauses in charters for street railways, $13-6$

Ritchie, Mr. C. P., against the General Power Distribution Bill, 275-6; on the Lancashire Power Bill, 280, $283-4$

Road authorities exacting as to terms, 23; difficult to deal with, 26-7

Salisbury, Marquess of, on terms offered electric companies, I93

Shaw-Lefevre, Mr., remarks of, introducing Tramways Bill, 1870, I I-I 4

Sheffield, street railways in, 139-40; admitted one electric light company and bought it out, $235^{-6}$

Shoolbred, J. N., on the electric light, $205^{-6}$
Slag, Mr., on Electric Lighting Act, 1882, 190-2

Smith, E. O., on electric lighting, 21 2-4, 228; on disfranchisement of corporate employees, 312-3

Southern, Mr. J. W., on disfranchisement of municipal employees, $314-5$

Standing Order No. 22, results of, 44-6; Earl of Morley advocates amendment of, 45-7; impeded the housing of the working classes, 48 ; amendment to, moved, 48; discussed and withdrawn, 49-5 I ; amended, 60

Steam or other mechanical power, applications to use, on tramways, refused, 27-8; Government unwilling to offend the opposing interests, 28; Committee of House of Commons to consider, 28; reported favorably on experimental use of, 29, 30; clause rejected by House of Lords, 30 ; principles to govern use of, 30-1; period of contract for, seven years, $3^{\mathbf{I}}$; provisions for use of, in Provisional Orders, 33; economy of steam power, 56-7; steam tramways, experiments with, in Edinburgh, 123

Street railway franchises, municipal trading in, $5 \mathbf{I}$

Street railways, request for a charter for, in London, denied, 7 ; attempts to build in the sixties, 8-9; general act for granting charters for, enacted, Io; built on the Continent, ro; success of the latter, 12; purchase clauses in charters for, 13; should be purchased by the municipality, 18; building of, paralyzed, I8-21; comparison of, with those of the United States, I 8-20; built only by municipalities under Act of 1870, 20; municipalities refused power to operate, $2 \mathrm{I}$; local authorities sell assent for, 22, 27, 46; burdens placed on, 33; net earnings of tramways of United Kingdom, 5I; should be encouraged, 55; in United Kingdom and United States, 87-9; comparison of trackage and population in, 89; comparison of track mileage in, 90-I; objections to extending, I 6

Street railways of Massachusetts, comparative results of horse and electric power on, 65 
Streets, belong to the public at large, 2; of London, too narrow to allow of tramways, 7; recognized control of, in danger, 269-70

Subways for electric railways recommended by Commission on transportation in London, 166-8; opposition to, from London County Council, r6g-7r

Swan, J. W., made earliest incandescent lamp, 4, 6

Swinburne, Mr., on removal of restrictions on electrical industry, $8 \mathrm{I}-2$

Swinton, Mr. A. A. C., on way Board of Trade plays into hands of local authorities, $25 \mathrm{I}-2$; on influence of owners of gas plants, 259

Telephone exchanges, in the United States and the United Kingdom, $301-3$; task of establishing, left to the UUnited States, 323

Train, George Francis, builds tramways in London, 8-9

Tramways, British, cable system not used on, 57

Tramways, declared a public benefit by a jury, 8 ; Bill for, on turnpike roads brought in, 9; opinion of Select Committee of I 860 on, I I ; initiative in building, repressed by Light Railways Act, 69, 86; local authorities authorized to purchasc, 79-80; construction of, hindered by demands of corporations, I I 9-2I; building of, in Birmingham discouraged, 132-3; checked by veto power, 157

Tramways Act, the, of $1870,7-67$; remarks of Mr. Shaw-Lefevre on introducing, $11-14$; leaves control with the municipalities, I6; para- lyzed private initiative, $2 \mathrm{x}-8$; motive power under, 27; paralyzing effect of, 60; twenty-one year compulsory sales clause in, 62; overridden in Birmingham, $13 \mathrm{I}$; not amended, 29 I

Tramways of Edinburgh under private management favor working classes, 118

United Kingdom, lack of street railways in, 87-91

Urban District Councils, Association of, 70-1

Ure, Sir John, on political power of municipal employees in Glasgow, 309-1 I

Vernon-Harcourt, Sir W., on great enterprises in private hands, 282-3

Veto power, abuse of, by municipalities, 22-7, 119, 154-7; failure of attempts to limit, 28, 33; extended to private charters, 44 ; repeal of the, opposed, 50; abolition of, advocated, I 56-7; provisional, 242-6

Wage-earners, municipalities versus the, 298-306; loss of employment to, $300-4$; indirect harm to, 304-6

Wolverhampton, action of, regarding clectric tramways, 43

Wood, Dr., on opposition of Edinburgh authorities to tramway company, 1 20-1

Wortley, Stuart, opposes General Power Distribution Bill, 272-3

Wyatt, R. H., on system of granting tramways, 25

Yorkshire Electric Power Co., 286-8

Young, John, on results of system of graded fares, 104-7, $110-11$ 




\section{Date Due}

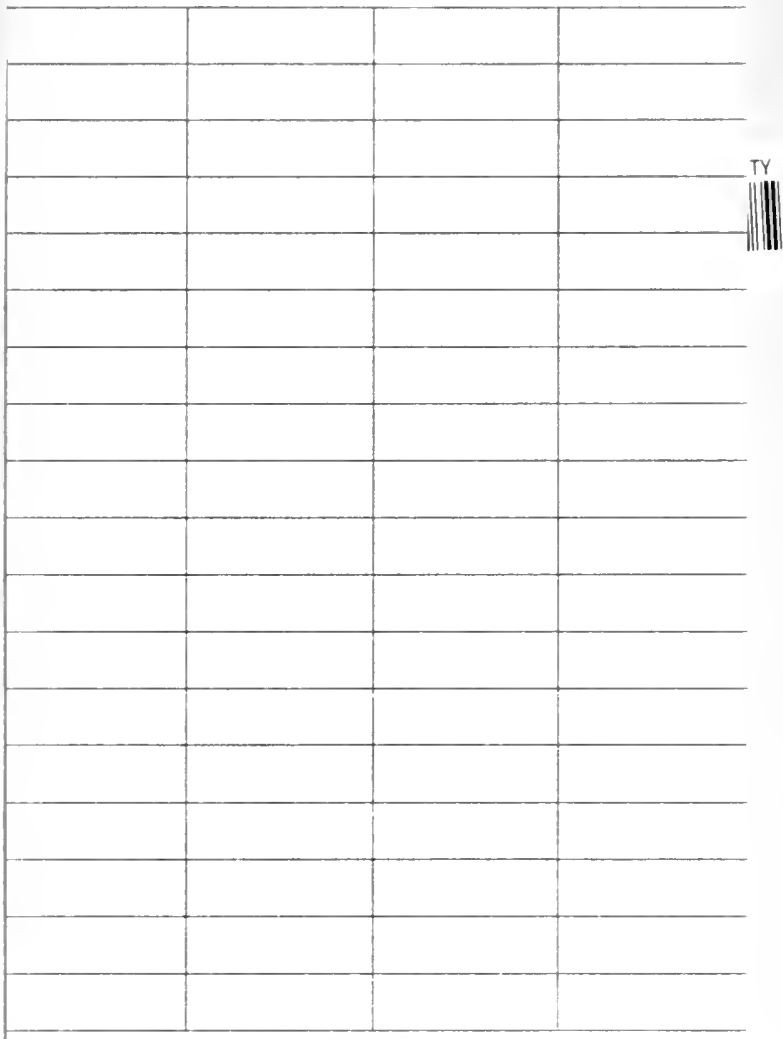

Library Bureau Cat. No. 1:37 
